Tectonics of

Southeastern Arizona

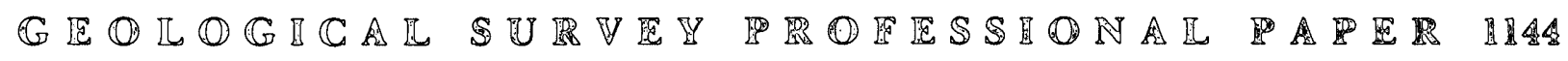

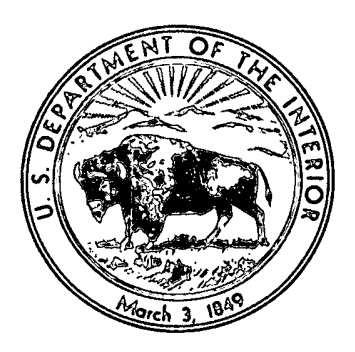




\section{Tectonics of \\ Southeastern Arizona}

By HARALD D. DREWES

GEOLOGICAL SUR VEY PROFESSIONAL PAPER 1144

A tectonic synthesis of a terrane deformed by recurrently active northwest-trending basement flaws, northeast-directed Cordilleran thrust faults, and north-trending Basin and Range normal faults

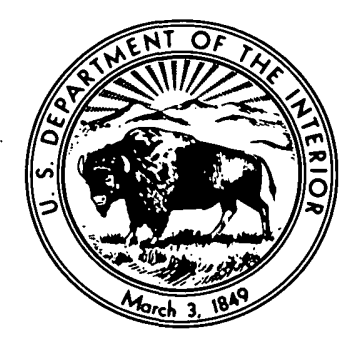




\section{UNITED STATES DEPARTMENT OF THE INTERIOR}

JAMES G. WATT, Secretary

\section{GEOLOGICAL SURVEY}

Doyle G. Frederick, Acting Director

Library of Congress Cataloging in Publication Data Drewes, Harald, 1927-

Tectonics of southeastern Arizona.

(Geological Survey Professional Paper 1144)

Bibliography: p. 90

Supt. of Docs. no.: 1 19.16:1144

1. Plate tectonics. 2. Geology-Arizona. I. Title. II. Series: United States Geological Survey Professional Paper 1144.

QE511.4.D73 $551.8^{\prime} 0979$

79-607166

For sale by the Superintendent of Documents, U.S. Government Printing Office Washington, D.C. 20402 


\section{CONTENTS}

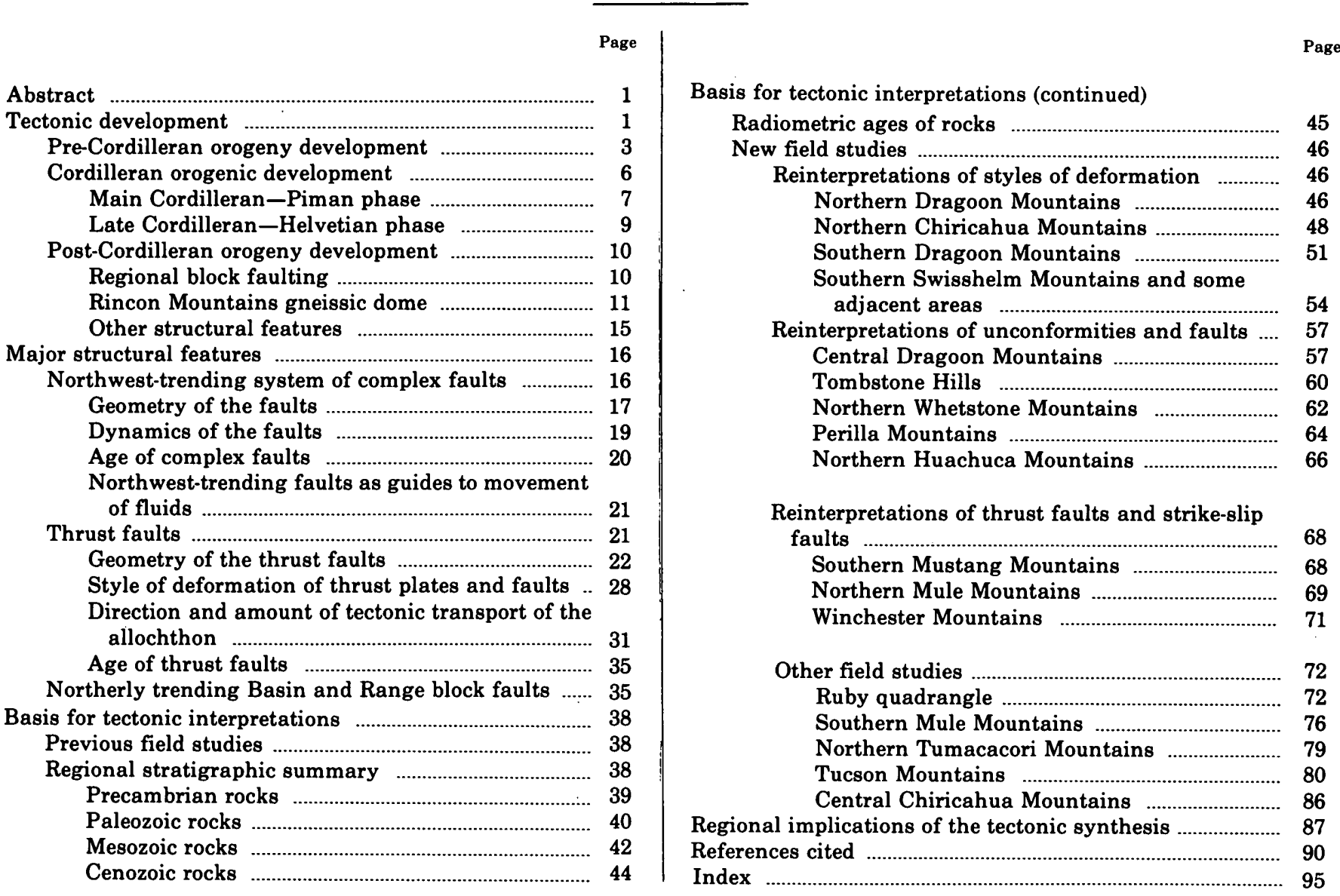

\section{ILLUSTRATIONS}

[Plates are in pocket]

Plate 1. Stratigraphic correlation chart of southeastern Arizona

2. Geologic map and structure sections of part of the northern Dragoon Mountains

3. Geologic map and structure sections of part of the northern Chiricahua Mountains near Marble Canyon

4. Geologic map and structure sections of part of the southern Dragoon Mountains between South Pass and Turquoise Mountain

5. Geologic map and structure sections of the southern Swisshelm Mountains

6. Geologic map and structure sections of the northern Huachuca Mountains

7. Geologic map and structure sections of the southern Mustang Mountains

8. Geologic map and structure sections of parts of the Ruby quadrangle

9. Geologic map of the Tucson Mountains between the Sus picnic area, Arizona Sonora Desert Museum, and Sahuaro School

10. Geologic map and structure sections of part of the central Chiricahua Mountains near Portal, Ariz. 
FIGURE 1. Index map showing the part of southeastern Arizona covered by tectonic synthesis ……....................................... 2

2. Northwest-trending complex faults ..............................................................................................................

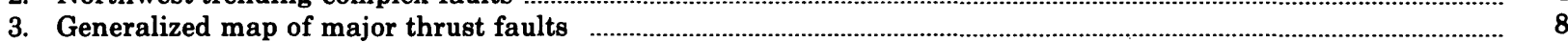

4. Basin and Range faults and related volcanic features …………......................................................................... 12

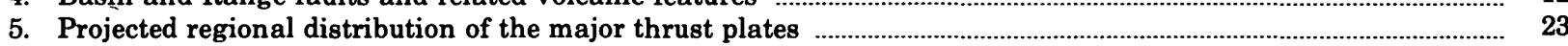

6. Diagrammatic structure sections of relations along the Sierrita line …........................................................................ 30

7. Geologic map and structure section of part of the central Swisshelm Mountains ……................................................. 56

8. Geologic map of the southeastern end of the Swisshelm Mountains and part of the Pedregosa Mountains along Walnut Canyon

9. Geologic map and structure section of part of the central Dragoon Mountains

10. Geologic map and structure section of part of the Tombstone Hills

11. Geologic map and structure section of the northern Whetstone Mountains

12. Geologic map of part of the Perilla Mountains

13. Geologic map of the northern Mule Mountains

14. Geologic map and structure sections of the Winchester Mountains

15. Geologic map of part of the southern Mule Mountains

16. Geologic map of the northern end of the Tumacacori Mountains

17. Geologic map of part of the Tucson Mountains near Twin Peaks 


\title{
TECTONICS OF SOUTHEASTERN ARIZONA
}

\author{
By Harald D. DREWes
}

\section{ABSTRACT}

The part of Arizona south and east of Tucson is underlain by a wide assortment of deformed rocks, as well as by some major mineralized districts. A synthesis of the tectonic evolution of the region is offered in this report, which is based on older studies of mining districts and on more recent field studies by students and by the U.S. Geological Survey, augmented by field review and selective remapping of many key areas. Through this synthesis the rocks of the region are seen to have been deformed in response to diverse stresses, at various times, with an increasing degree of structural anisotropy of the rocks through time. Consequently, reactivated faults are common features, and segments of some of these faults record various kinds of movement, thereby providing unusual interpretive difficulties for many of the past local studies.

Major deformation of the rocks of southeastern Arizona occurred during the Precambrian, early and middle Mesozoic, latest Mesozoic and earliest Cenozoic, and late Cenozoic times. The younger deformations generally obscure the record of the older ones, of which only the largest or most widespread structural features are preserved. During the Mazatzal Revolution of Precambrian age the rocks were deformed, metamorphosed, and extensively intruded by granitic bodies. Epeirogenic movements occurred during the late Precambrian and Paleozoic. Block faulting and plutonic emplacement were recurrent between the Triassic and earliest Cretaceous. The Cordilleran orogenic period, of Late Cretaceous and Paleocene time in this region, was marked by compressive deformation, abundant granitic intrusion, and mineralization. This compressive deformation led to large-scale thrust faulting, tear faulting, and folding. During mid-Tertiary to Holocene time the rocks were faulted in response to east-west oriented tension, and were again invaded by magmas, to form the features typical of the Basin and Range province. Where local topographic relief was extreme, as over some raised blocks or gneissic domes, tectonic denudation features developed.

This tectonic evolution is found to be substantially consistent for most of the region. More than 130 radiometric age determinations provide useful control of tectonic events. Key areas that were remapped or mapped in detail for the first time for this study lie in the Dragoon, Chiricahua, Swisshelm, Whetstone, Perilla, Huachuca, Mustang, Mule, Winchester, Pajarito, Tumacacori, and Tucson Mountains, and the Tombstone Hills. The mapping of other ranges is published separately, as is the regional geologic-tectonic map on which the results of these local studies are compiled.

Three major fault systems are present. The first system comprises northwest-trending high-angle faults with a complex history of movement ranging in age from Precambrian through Cenozoic and is seen as the master system. The second system comprises thrust faults that disrupt the rocks, forming extensive allochthonous sheets, mainly of Paleozoic and Mesozoic rocks but including some of the Precambrian crystalline basement rocks. The third, a northerly trending normal fault system, cuts the other major structures. The movement of magma and mineralizing fluids was typically controlled first by the location and condition of the northwest-trending master faults, and then by second-order faults, favorable rock types, and other features.

The synthesis reveals a coherent system of regional structures that developed in a sequential manner. The tectonic development is seen to be compatible with that of the Cordilleran orogenic belt, which extends from Alaska to Guatemala. Also, it is seen to fit the currently favored model of plate tectonics, in which the orogenic belt is the result of gradual convergence of the North American and various Pacific plates between the mid-Atlantic and midPacific spreading centers over a protracted span of time.

\section{TECTONIC DEVELOPMENT}

The rocks of much of southeastern Arizona are complexly deformed. Most structural features of the region were formed during part of the Cordilleran orogeny of Late Cretaceous and Paleocene age, but they were controlled in part by some older structures and were modified by younger ones. Variations in kind and degree of structural complexity are due largely to a variable local geological history.

The term "Cordilleran orogeny" is preferred herein for the sum of geologic events that produced the entire Cordilleran orogenic belt. Those events of shorter duration or more limited distribution within the framework of the whole belt are viewed as phases of this orogeny, as explained more fully by Drewes (1978).

The region covered by this tectonic synthesis extends from the Tucson Mountains at Tucson, Arizona, south to Sonora and east to New Mexico (fig. 1). Most of the geologic work is summarized on a map by Drewes (1980) that extends north to lat $32^{\circ}$ $15^{\prime}$ and west to long $111^{\circ} 15^{\prime}$. While this area of nearly $24,000 \mathrm{~km}^{2}$ is considerably less than the southeastern quarter of the State, for simplicity in this report it will be referred to as southeastern Arizona. As 


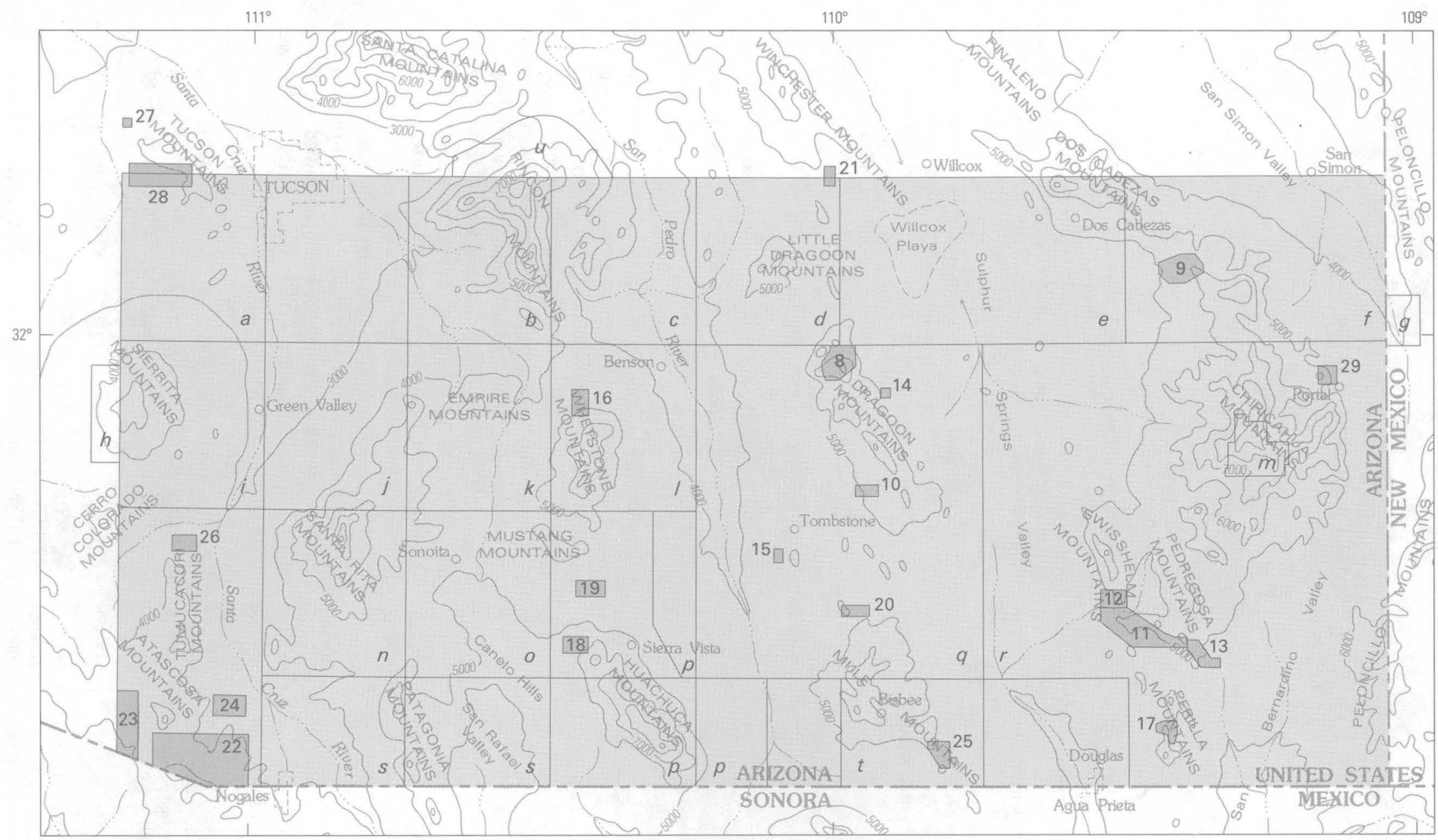

FIGURE 1.-Index map showing the part of southeastern Arizona covered by the tectonic synthesis, some major geographic features, and the sites of recent detailed field mapping upon which are based many of the ideas presented herein. Published maps extensively used in the synthesis are: $a$ Brown (1939); $b$, Drewes (1977); $c$, Drewes (1974); $d$, Cooper and Silver (1964); $e$, Cooper (1960a); $f$ Sabins (1957a); G Gillerman (1958) and Armstrong and Silberman (1974); $h$, Drewes and Cooper (1973); $i$, Cooper (1973); $j$, Drewes (1971a); $k$, Finnell
(1971); $l$, Creasey (1967); $m$, Drewes and Williams (1973); $n$ Drewes (1971b); o, R. B. Raup (written commun., 1968); $p$, Hayes and Raup (1968); $q$, Gilluly (1956); $r$, Cooper (1959); $s$ Simons (1974); $t$, Hayes and Landis (1964); and $u$, Thorman, Drewes, and Lane (1978). Maps included in this report are identified by their respective figure numbers. Base from Defense Mapping Agency Aerospace Center, scale 1:1,000,000, ONC H-22, edition 8 (1969); contour interval $1,000 \mathrm{ft}$. 
shown by figure 1 , this study is based on compilation of published maps augmented by new mapping.

\section{PRE-CORDILLERAN OROGENY DEVELOPMENT}

Structural features that are older than the Cordilleran orogeny provide some controls and constraints on Cordilleran faulting. Typically, evidence of the antiquity of these features is blurred by subsequent geologic events, and most details of the early development remain unknown. Nevertheless, the older structural features are of great importance because they are among the first ones known to implant a structural anisotropy on the rocks of the region, which thereafter influenced the responses to further crustal stresses.

The geologic record of the region begins with the deposition of the Pinal Schist. This formation is best known from the Little Dragoon Mountains, where Cooper and Silver (1964) describe it as comprising sedimentary and volcanic rocks, perhaps as much as $6,000 \mathrm{~m}$ thick. A rhyolite mass associated with the metasedimentary rocks is dated as slightly older than 1,700 m.y. (million years).

During the Mazatzal Revolution (Wilson, 1939; Anderson, 1951), about 1,500-1,700 m.y. ago, the rocks of the region were deformed, metamorphosed, and intruded. Foliation parallel to bedding is widespread in these rocks and may be an early load. related feature of this period. The foliation is commonly crenulated. In places folds of larger amplitude were also developed, which reflected a more substantial lateral movement and were likely a response to horizontal compression of unknown orientation. Some of these rocks are also lineated. While rocks having a pronounced lineation, such as the Rincon Mountains, may have received this stamp at a later time, some lineation may date back to the Mazatzal Revolution. These rocks are commonly intruded or unconformably overlain by rocks of later Precambrian age and, where these are absent, by Paleozoic formations, thereby demonstrating their antiquity.

Large masses of granitic rocks intruded the foliated and folded ancient rocks during late orogenic (Mazatzal Revolution) and early postorogenic time. At the present level of exposure, reflecting mainly Precambrian erosion, these intrusive masses are of stock and small batholith size, and are more extensive than their host rocks. Their outcrop configuration is generally determined by younger structural features and erosion, although some may have a preferred northwest orientation.
The magmatic episode was accompanied by a regional metamorphism that produced gneiss, schist, phyllite, and assorted meta-igneous rocks. Foliation development overlapped the emplacement of the earliest stocks of about 1,650 m.y. age, but not that of the younger stocks of about 1,450 m.y. age. More systematic studies of the metamorphism will probably show that an early, more intensive alteration was followed by a retrograde greenschist facies metamorphism.

Late in the Mazatzal Revolution or just after it, the region was cut by many northwest-trending faults (fig. 2), and subsequently was uplifted and peneplaned about 1,250 m.y. ago. These faults probably had large amounts of both strike-slip and dip-slip displacements, for along some of them, markedly diverse Precambrian rocks are juxtaposed though no such relationship is seen in Paleozoic or younger rocks. Furthermore, along the Apache Pass fault zone in the Dos Cabezas-Chiricahua Mountains, folds of large amplitude and steep plunge that abut the fault on the southwest are unconformably overlain by Paleozoic rocks. Folds that abut, rather than are cut by, faults typically suggest strike-slip movement. About $60 \mathrm{~km}$ farther north in the Pinaleno Mountains, Swan (1975) inferred another northwest-trending fault to have been active during Precambrian time, based on another kind of evidence.

After the erosion to peneplane conditions about 1,250 m.y. ago, the sea transgressed the region and a second suite of Precambrian rocks, consisting of sedimentary rocks, was deposited, to form the Apache Group (Shride, 1967). Block faulting and intrusion of 1,040- to 1,200-m.y.-old diabase into the Apache Group occurred mainly north of the region. Subsequent uplift, northward tilting, and extensive erosion removed the upper part of the group from the area near Tucson, and the entire group from the rest of southeastern Arizona.

Paleozoic structural features consist of disconformities in a marine sequence. These show the prevalence of epeirogenic conditions of little consequence to subsequent tectonic activity. By the middle of the Permian Period marine conditions gave way to dominantly continental subaerial conditions in the region.

During Triassic to Early Cretaceous time, at least two of the northwest-trending complex faults (fig. 2) were active and several stocks were emplaced. The term complex fault is herein applied specifically to faults that have been reactivated and, in some cases, 


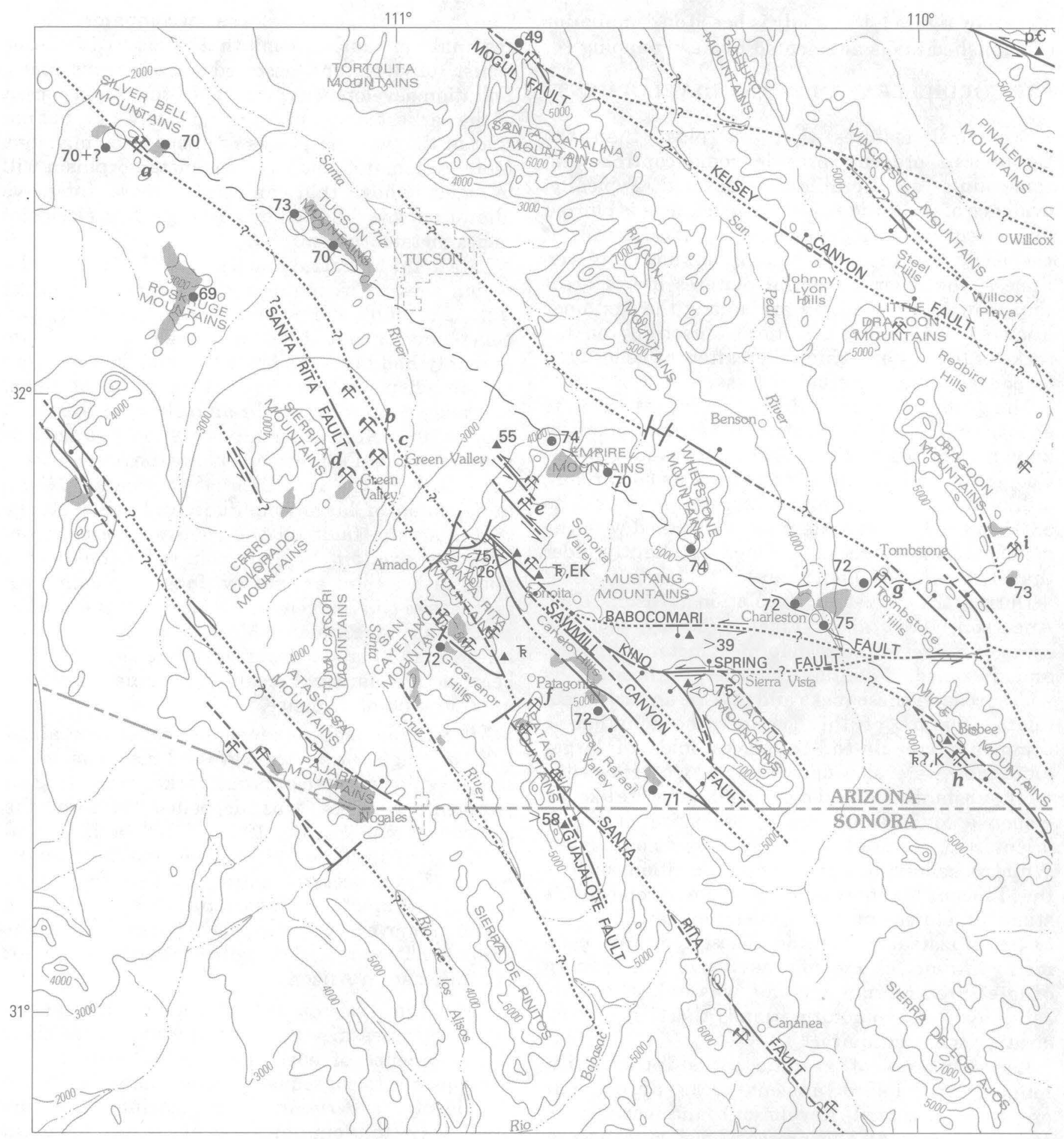

50

100 KILOMETERS

have had several kinds of movement at various times; they deserve special attention because from place to place the available evidence of their history of movement is in apparent conflict.
Major northwest-trending fault blocks, bounded by complex faults, formed during the Triassic in the western part of the region; erosion exposed Precambrian basement in the most strongly uplifted 


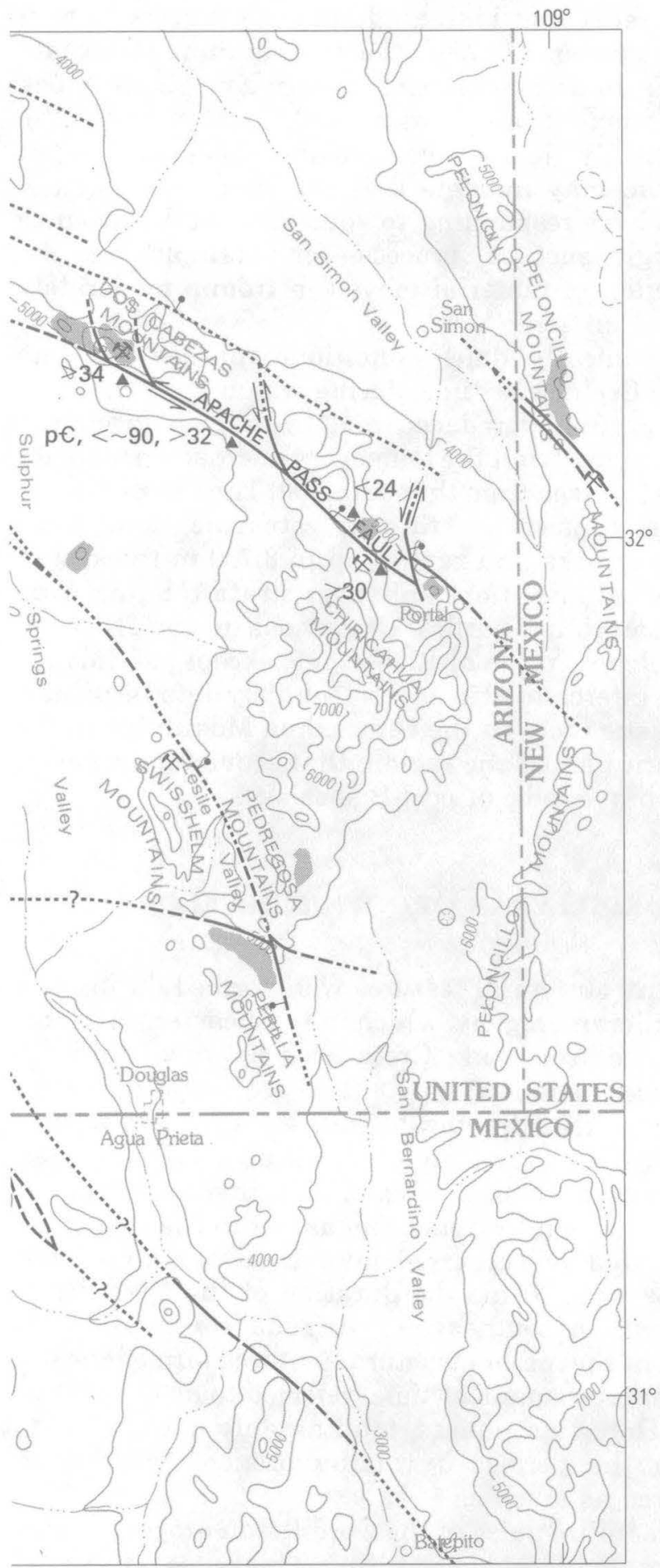

EXPLANATION

$\square$ VOLCANIC ROCKS OF THE SILVER BELL-CAT MOUNTAIN-SALERO SUITE

GRANODIORITE STOCK OF THE 70-74 M.Y. AGE GROUP-Dashed where inferred from geophysical data

$\Longrightarrow$ - FAULT-Dashed where inferred, dotted where extensively covered or intruded, queried where uncertain. Double headed arrows show evidence only of horizontal movement but without relative movement. Other arrows show sites of evidence for strike-slip movement. Bar and ball show site of evidence of vertical movement or of inferred vertical offset; ball on downthrown side

$\sim$ TRACE OF INFERRED FRACTURE IN BASEMENT ROCKS

-70 SITE OF RADIOMETRICALLY DATED ROCK AND AGE IN MILLIONS OF YEARS

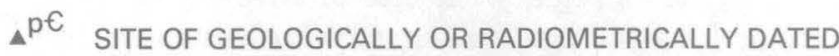
ROCKS-Indicates age or age limits of some phase of movement (in millions of years or geologic age series)

2 2 MINING DISTRICTS-Large size and middle size (more than approximately $\$ 100$ million, and $\$ 10-\$ 100$ million, respectively). $\boldsymbol{a}$, Silver Bell; $\boldsymbol{b}$, Pima-Mission; $c$, Twin Buttes; $d$, Esperanza-Sierrita; $e$, Rosemont; $f$, Red Mountain; $g$, Tombstone; $h$, Bisbee-Warren; $i$, Courtland-Gleeson

FIGURE 2 (left and above).-Northwest-trending complex (or multiphased) faults, showing sites of inferred directions and ages of movement, and some associated igneous rocks. Much fault movement was pre-Cordilleran orogeny. Base from Defense Mapping Agency Aerospace Center, scale 1:1,000,000, ONC H-22, edition 8 (1969); contour interval 1,000 ft.

block and filled the adjacent basin with a thick pile of volcanic and sedimentary rocks. In the Late Triassic, during another period of faulting, a zone of the Triassic volcanic rock was upended, and several stocks of Late Triassic age were emplaced. One of these stocks, the Piper Gulch Monzonite, appears to be emplaced along the complex fault that upended the Triassic rocks in the Patagonia and Santa Rita 
Mountains. Altogether, these tectonic and magmatic events may be the marginal effects of the Sonoran orogeny reported by Fries (1962) in southern Sonora.

Additional granitic magmas were emplaced at several localities in the western half of the region during the Jurassic, and volcanic ash was deposited mainly in a northwest-trending zone between the south end of the Huachuca and the Tucson Mountains. Older structures may have controlled the emplacement of some of these stocks, for the stocks have northwest-trending straight segments against older rocks and appear to have intruded, to the point of near obliteration, the Santa Rita complex fault, leaving only a relict fault or fault scar in the Santa Rita and adjacent Patagonia Mountains. The extensive copper mineralization at Bisbee is apparently associated with one of these magmatic centers of Jurassic age, and the mineralization at the Montosa Mine on the west side of the Santa Rita Mountains could also be deposited in the wall rocks of a Jurassic body; these age assignments merit further scrutiny because they are atypical of so much other mineralization and because the possibilities of mineral remobilization or multiple times of mineralization may have to be considered in determining the history of mineralization. Dating mineral deposits is frequently more difficult than dating emplacement of a stock.

By at least the early Early Cretaceous, part of the northwest-trending Sawmill Canyon complex fault (fig. 2) was reactivated, and the block to the northeast was raised recurrently, shedding successive wedges of fanglomerate southwestward into the adjacent basin, where they were intercalated with abundant volcanic rocks. Andesitic, dacitic, and rhyolitic volcanic rocks accumulated in the Sierrita and Huachuca Mountains; and in the adjacent areas, the Paleozoic and Mesozoic rocks were eroded to various stratigraphic levels, leaving surfaces of moderate to low relief that were gradually buried by the widespread clastic rocks of late Early Cretaceous age.

During the time interval of Triassic through early Early Cretaceous, then, moderately active tectonic conditions prevailed in the central and western part of the region. The absence of any record in the eastern part might imply the existence of more stable conditions in which no deposition, or even gradual erosion, occurred. More detailed studies there may augment our knowledge of the elusive parts of the record. Vertical tectonic activity appears to have been dominant in central and especially western southeastern Arizona; tensional conditions appear to have prevailed. The association of considerable local relief and high-angle faults suggests normal fault movement. And the combination of normal faults and magmatism (embracing both stock emplacement and volcanism), not preceded by genetically related compressive or shear deformation, may indicate that the lower parts of the crust were responding to some distant disturbance through such a process-for example, as the accretion of material moved in from a moderately distant orogenic belt.

Tectonically quiet conditions marked the late Early Cretaceous time, during which the local relief was gradually reduced and the region gradually lowered to permit the temporary encroachment of an arm of the sea from the southeast. The Bisbee Group, which consists of fluvial, estuarine, and some marine rocks and ranges up to $3,700 \mathrm{~m}$ thick, was deposited unconformably over strata ranging from Precambrian to earliest Cretaceous in age. There are no volcanic rocks of Bisbee age, except possibly for some intercalated in an inadequately dated sequence of clastic rocks in the Chiricahua Mountains in the eastern part of the region; that sequence, however, may prove to be of post-Bisbee age.

\section{CORDILLERAN OROGENIC DEVELOPMENT}

Many structural features were formed during the Cordilleran orogeny, which in southeastern Arizona extended from Late Cretaceous $(90 \mathrm{~m} . \mathrm{y}$.$) through$ Paleocene time (53 m.y.). The sequential development of the structural features is generally uniform through the region, but not all events occurred in every part of the region. Furthermore, not all events were fully synchronous, for to the east some seem to have occurred later than similar events to the west. While the duration of the Cordilleran orogeny in southeastern Arizona covers 37 m.y., most of the major structural features formed during two shorter spans of time, referred to as the Piman and Helvetian phases, totaling only about $12 \mathrm{~m} . \mathrm{y}$. Even the period of waxing orogenic conditions covered as much as 15 m.y.

The initial pulse of the Cordilleran orogeny was a modest uplift and local tilting. This pulse is recorded by a subtle angular unconformity between Lower and Upper Cretaceous rocks and by a basal conglomerate in the Upper Cretaceous rocks derived in part from detritus of the Lower Cretaceous rocks. Precise dates for this pulse are lacking in southeastern Arizona, so I have used data from west Texas and the San Juan Basin, where the sedimentary record is well dated (Drewes, 1972a, p. 30). 
MAIN CORDILLERAN-PIMAN PHASE

Waxing orogenic conditions of the Piman phase of the Cordilleran orogeny are recorded in the Upper Cretaceous rocks of southeastern Arizona by the general upward increase in coarseness and angularity of the sedimentary rocks, and by an upward increase in the abundance and kind of volcanic rocks. Where the record of Upper Cretaceous deposition is most extensively developed, in the Santa Rita Mountains and the Cabullona area of Sonora, $25 \mathrm{~km}$ southwest of Douglas (Taliaferro, 1933), the basal conglomerate is overlain first by a substantial thickness of shale and siltstone, then by sandston'e, siltstone, and some conglomerate that contains clasts of volcanic rocks, and finally by abundant coarse conglomerate. In some areas this sequence is overlain by thick-bedded to massive fanglomerate. Thin beds of tuffaceous rocks appear high in the coarse conglomerate, and massive fanglomerate sequences and volcanic rocks are the dominant rock type above it. Andesitic or dacitic flow breccia is widely distributed; these rocks are older than about $72 \mathrm{~m}$.y. in the western part of the region, where overlying rhyodacite welded tuff is dated. Similar andesitic or dacitic flow breccia and some associated tuffaceous and epiclastic volcanic rock may be younger in the eastern part of the region, and correlative rocks in southwestern New Mexico seem to include some of Paleocene age.

In many places both the andesitic breccia and the rhyodacite welded tuff contain chips or blocks of assorted older material. Because clasts or xenoliths of this assemblage are not typically found in places nearby, they have frequently been called exotic blocks; but the blocks need not come from unknown or far distant sources. Exotic blocks are typically derived from Paleozoic formations, and in at least six mountain ranges they reach a size of hundreds of meters long. A variety of origins have been proposed for these blocks in a volcanic matrix; all are variations of a volcanotectonic process. Many or all of these explanations may be correct for their local situations, because separate centers of volcanism are involved, and conditions may have varied from center to center. Of key significance to the tectonic conditions about $72 \mathrm{~m}$.y. ago is the wide extent of high-energy volcanism, which I will discuss after reviewing the tectonic development of this main phase of the Cordilleran orogeny of southeastern Arizona.

During the Piman phase of the Cordilleran orogeny (Drewes, 1972a), the rocks were uplifted, thrust faulted, and folded. Toward the end of this phase, volcanotectonic rocks were spread from many centers and large epizonal stocks were emplaced. The uplift, which initially was probably regional, gradually became differential local uplift. This uplift and the first volcanic rocks are essentially part of the waxing orogenic time. But by about 73-75 m.y. ago, strong northeast-southwest-oriented, and probably northeast-directed, compressive stress was applied to the region. In response to this stress the rocks warped about northwest-oriented fold axes and tore loose from each other, commonly along available planes of weakness, such as the interface between the crystalline basement, replete with its massive granitoid stocks, and the layered Paleozoic and Mesozoic rocks, to form several thrust plates of regional extent (fig. 3). Allochthonous rocks are recognized in most of the mountain ranges of the region. Much of the stress was taken up between autochthon and allochthon and between major plates of overthrust rocks; additional stress was taken up within plates by smaller bedding-plane faults, along which younger rocks commonly moved over older ones, and by disharmonic folds within certain parts of plates.

The amount of movement on the regional thrust faults is believed to be large. On the basis of the distance in the direction of transport over which formations are repeated, the amount of movement on a major thrust fault is at least $15 \mathrm{~km}$ and probably is more than $30-35 \mathrm{~km}$. On the conjectural basis of offset of a Jurassic stock, the actual amount of tectonic transport on one of two major thrust faults may be about $100 \mathrm{~km}$. Even if the movement on the lower major fault, separating allochthon from autochthon, was only the same amount $(100 \mathrm{~km})$, the total distance of transport of all plates may have been nearly $200 \mathrm{~km}$. The thrust faults of the Piman phase of the Cordilleran orogeny are regional features by virtue of their widespread extent, uniform environment of formation, and large distance of tectonic transport.

Local differential stresses within the plates caused them to tear apart along northeast-trending faults. The largest of these tear faults (Sierrita line) appears to have divided the plates into major northwestern and southeastern portions, which then moved independently of each other. When considered along with their likely extensions beyond the area of this synthesis, the present-day leading edges or thrustfault traces of these semi-independent parts of the allochthon appear lobate in plan. They are therefore referred to as the northwestern and southeastern lobes (fig. 3), and their separation is based on their somewhat different internal characteristics. The southeastern lobe contains two main thrust plates 


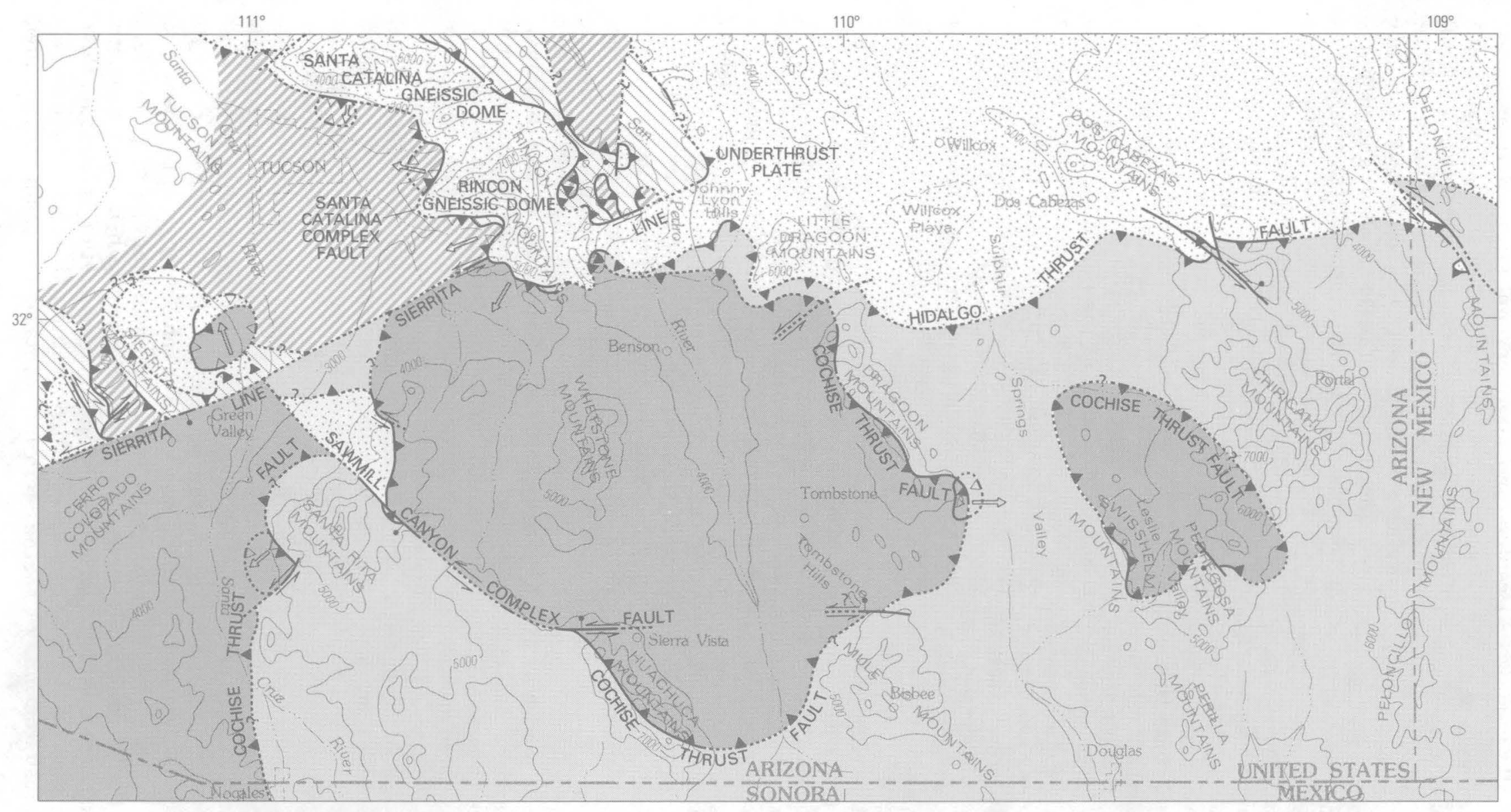

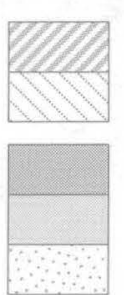

ALLOCHTHON NORTHWEST LOBE: Upper and middle plates

Lower plate

ALLOCHTHON, SOUTHEAST LOBE:

Cochise plate

Hidalgo plate

AUTOCHTHON
EXPLANATION

FAULTS-Dotted where concealed or intruded; queried where uncertain

where uncertain
Normal fault-Bar and ball on downthrown side
Thrust fault-Sawteeth on upper plate
Glide fault or low-angle normal fault-Open teeth on glide
plate or hanging wall; arrow shows glide direction

FIGURE 3.-Generalized map of major thrust faults of Cordilleran age, separating allochthons from each other and from the autochthon. Base from Defense Mapping Agency Aerospace Center, scale 1:1,000,000, ONC H-22, edition 8 (1969); contour interval $1,000 \mathrm{ft}$. 
and involves some basement rocks along the base of the upper main plate in a minor way. The leading of this lobe trends eastward into New Mexico from a point northeast of Benson. Few of the rocks of these plates are dynamically metamorphosed. By contrast, the northwestern lobe may contain three major plates, the middle one of which is of Precambrian rocks, as far as has been mapped. The rocks of the lower plate are dynamically metamorphosed. This lobe front trends northwestward from a point northeast of Benson. Possibly the leading edge of the allochthon is locally thrust under or jammed into the subjacent autochthon (or hence, para-autochthon), as west of the Rincon Mountains.

In many places, existing discontinuities or planes of weakness, such as the top of the crystalline basement or the shale formations, have localized thrust faults. In a few cases major geologic obstacles to thrust movement probably were encountered, such as Jurassic stocks that had penetrated high into the Paleozoic sequence or fault blocks bounded by complex faults with large uplift on their northeastern side. The full evaluation of these features requires further study, but the map synthesis presented by Drewes (1980) can accommodate these obstacles to thrust movement. For example, the Jurassic stock of Gleeson Quartz Monzonite in the southern part of the Dragoon Mountains is seen to be truncated downward by a major thrust fault (Gilluly, 1956; McRae, 1966, among others), which is herein (pl.4) identified as the Cochise thrust fault, at the base of the upper main plate. Possibly the Jurassic granite and quartz monzonite of the west flank of the Santa Rita and Patagonia Mountains is the structurally downward extension of the Gleeson stock in the Hidalgo thrust plate. Presumably, then, the Squaw Gulch-Patagonia stock (or batholith) is also truncated downward by the Hidalgo thrust plate. Updip to the northeast, this plate is cut by the Sawmill Canyon complex fault near the present surface. The Cochise thrust fault, which lies just below the present surface northeast of the complex fault, must project above the Squaw Gulch Granite and must also approach the position of the present surface near the complex fault, near which no Hidalgo plate is recognized.

At considerable depth beneath the surface, magmatic activity probably accompanied the compressive deformation. With the relaxation of compressive stress, shortly after the peak of the compressive deformation, the magmas migrated upward and penetrated both the bedded rocks and thrust faults. Stocks are numerous, large, and composite to the west, where they are mostly dated at 67-69 m.y. old; there are fewer, smaller, and simpler intrusive bodies to the east. The oldest stocks to the west, however, are small ones dated at 70-75 m.y., essentially the age of the rhyodacite volcanic rocks. These stocks are alined in a northwest-trending belt that extends at least from the Charleston-Tombstone area to the Tucson Mountains (fig. 2). Extensive accumulations of rhyodacite welded tuff that contain exotic blocks occur near most of these stocks. Apparently these stocks were the first ones formed after the time of peak orogenic conditions. In a few places the underlying andesitic or dacitic flow breccia is seen to be thrust faulted, but the rhyodacite welded tuff and associated stocks are not. Perhaps then, the high-energy tectonovolcanic breccias were produced while the surrounding rocks were still under residual lateral compression; in effect, they may have had to penetrate a lid under lateral compression, which briefly retarded their upward movement until sufficient extra energy was built up and (or) the compressive stress was released to overcome the resistance of the lid. Then the initial release was exceptionally explosive.

\section{LATE CORDILLERAN-HELVETIAN PHASE}

During the late (Helvetian) phase of the Cordilleran orogeny, volcanism and intrusion of stocks and smaller bodies continued, strike-slip movement took place along the northwest-trending complex faults, and locally the rocks were thrust faulted and mineralized. Magmatic activity of this phase was greatest in the western part of the region. Several large granodiorite stocks were emplaced around $58 \mathrm{~m} . \mathrm{y}$. ago in the Patagonia and Sierrita Mountains, about coevally with the deposition of andesitic to rhyolitic rocks and some sedimentary rocks in adjacent mountain ranges. The subsequent emplacement of many small stocks, plugs, and dikes may have peaked at about 54-56 m.y., but probably continued throughout the Paleocene. These rocks range more widely in texture and composition than those of the large bodies, and they include a variety of quartz latite porphyry that is locally called the ore porphyry for its close spatial and perhaps also genetic association with porphyry copper type of mineralization. To the east, the few stocks of late Cordilleran age are even younger-50-52 m.y.

Left-lateral strike-slip movement on northwestern faults occurred about simultaneously with the last phase of magmatism of the Cordilleran orogeny. In the northern part of the Santa Rita Mountains, this movement is closely dated through bracketing ages 
of several stocks and plugs. Elsewhere the age of this movement is less closely dated but characteristically is seen to be younger than the major thrust faults and older than stocks or volcanic rocks of Oligocene age. Locally, however, segments of these complex faults were reactivated. At several places, other faults and small folds were formed subordinately to the major strike-slip faults. Most commonly, subordinate highangle faults that have a substantial component of strike-slip movement splay off the major faults. In the northern part of the Santa Rita Mountains, segments of older thrust faults near the strike-slip faults were reactivated. And very locally, drag folds and disharmonic folds were formed adjacent to the tear faults and their associated small thrust faults.

The change in orientation of stress field from that leading to northeast-directed thrust faulting to that leading to left-lateral movement on the northwesttrending steep faults need not have been large. Inasmuch as the northwest-trending faults were already present, their reactivation might come about by a force applied obliquely to the ancient flaws. Thus a shift in major stress direction from N. $60^{\circ} \mathrm{E}$. (essentially at right angles to the strike-slip faults) to due east may have been enough to produce the change from thrust faulting to tear faulting.

During both the Piman and Helvetian phases of the Cordilleran orogeny, the northwest-trending complex faults acted both as localizers or channelways for fluids and as strike-slip faults. In fact, it seems likely that their significance in the tectonic development of the region is greater than that of any other structural feature. The alined stocks of the 70- to 75-m.y. age group follow a northwest trend that probably marks a concealed flaw in the basement rocks. In the western part of the region the large stocks 67-69 m.y. old and those 58 m.y. old are elongate northwesterly, have some very regular northwest-trending steep margins, and in part lie along exposed faults of the northwesttrending set. Not only was the movement of magmas guided by these major basement flaws, but mineralizing fluids likewise seem to have been concentrated chiefly along second or third order faults and (or) favored lithologic horizons, a few kilometers from the major flaws.

\section{POST-CORDILLERAN OROGENY DEVELOPMENT}

During post-Cordilleran orogeny time the region was repeatedly block faulted, local masses were uplifted, and some stocks and dike swarms were emplaced (fig. 4). Early in this period the region was tectonically quiet. The terrane that was uplifted during the preceding orogenic time was eroded, and the detritus thus obtained was transported by streams to basins of deposition outside of southeastern Arizona. Only a few igneous rocks, whose ages are not well established by isotopic methods, may have been emplaced during Eocene time.

\section{REGIONAL BLOCK FAULTING}

The present Basin and Range topographic features first took form as early as Oligocene time, when north-trending normal faults bounded downdropped blocks, and some magmas and rock masses moved upward. Where segments of the northwesttrending complex faults were available, movement on them was reactivated. In fact, the general trend of the Basin and Range faults, which is northerly in the southern and central parts of the region, shifts northwesterly in the northern part of the region, probably because of the greater influence there of the older complex faults. In several places, Basin and Range faults trend northeast; these segments of the fault system are seen from field evidence to be mainly younger than the dominant north-trending segments.

Rhyolitic to rhyodacitic extrusive rocks formed extensive ash fields and some intercalated lava flows. Dike swarms, extrusive domes, and bulbous laccoliths, typically of vitrophyric rock, are genetically associated with the volcanic fields. Some dike swarms also cut rocks in mountain ranges that have few or no mid-Tertiary volcanic rocks. In many places these swarms trend easterly $\left(\mathrm{S} .70^{\circ} \mathrm{E}\right.$. to $\mathrm{N}$. $60^{\circ} \mathrm{E}$.) across the grain of the Cordilleran structures. Where the volcanic fields are most extensive, in the Tumacacori Mountains and Grosvenor Hills of the southwestern part of the region and in the Chiricahua and Peloncillo Mountains of the eastern part, volcanotectonic collapse structures are reported, along with welded tuffs (Marjaniemi, 1968; Drewes, 1972b). Volcanic collapse in the Grosvenor Hills utilized a rectilinear fault system and is associated with only a relatively small volume of welded tuff. The more extensive welded tuff of the Chiricahua Mountains may be associated with caldera structure, as proposed by Marjaniemi (1968). More detailed study there and in the Peloncillo and Tumacacori Mountains may lead to the recognition of other calderas of mid-Tertiary age.

Plutonic rocks of Oligocene age are associated either with the volcanic fields or with major structural domes. A small granodiorite stock in the San Cayetano Mountains is genetically related to the volcanic field in the adjacent Grosvenor Hills 
(Drewes, 1972a). Another mid-Teritiary intrusive mass occurs in the Chiricahua Mountains amidst a volcanic field. This rock is finer grained than typical stocks and grades into a latite porphyry mass that broached the surface as an extrusive dome (Drewes and Williams, 1973). The presence of this midTertiary stock at the present surface thus is due to emplacement very close to the surface rather than to strong upfaulting and extensive erosion.

Other stocks of mid-Tertiary age are not obviously related to volcanic activity. Some of them, north and northeast of Tucson, may be genetically related to the uplift of a northwest-trending compound gneisscored dome, parallel to the complex-fault system. This dome has three major summits, one of which underlies the Rincon Mountains, along the northern edge of the region under study. The other major summits underlie the Santa Catalina and the Tortolita Mountains north of the region. The largest of the mid-Tertiary stocks of the region, the Stronghold stock, occurs southeast of the Rincon gneiss-cored dome in line with the other major summits. Conceivably this large stock is related to the late magmatic development of the compound gneiss-cored dome.

\section{RINCON MOUNTAINS GNEISSIC DOME}

The rocks of the Rincon Mountains are especially complexly deformed as a result of an involved sequence of tectonic events. Some of the earliest tectonic events have already been reviewed in previous sections. The development of an intense and deeply penetrative lineation and foliation in conjunction with pervasive cataclasis is thought to date largely from the Cordilleran orogeny, although some enhancement of this fabric may be as young as Miocene. The cover, mainly of sedimentary and metamorphic rocks of late Precambrian, Paleozoic, and Cretaceous ages, was thrust faulted during the Cordilleran, as were rocks of the same age in most of the adjacent mountain ranges. Massively intruded heated rocks of the core were deformed, first plastically and then brittlely, as magmatic and tectonic activity overlapped. However, many of the conspicuous structural features of the Rincon gneisscored dome were formed during post-Cordilleran time. Some of these features can be specifically dated as mid-Tertiary or as late Tertiary, and others are inferred to have formed over a longer period of time that could even have lasted from late Cordilleran (perhaps late Paleocene) to Oligocene time. The domical structure along with its several subordinate minor highs and gently southwest-plunging anticlines and synclines, best shown on quadrangle maps (Drewes, 1974 and 1977), may have formed at depth during this period. The strong uplift of the dome and the small folds in both the crystalline rocks of the core and the sedimentary rocks of the cover on the flanks of the dome may also be of this age, but a bit younger. A slow cooling rate, rather than a second heating of the rock during the midTertiary, led to metamorphism and protracted magmatic intrusion. Glide plates, landslide masses, slump fields, and fanglomerate deposits were formed near or at the surface as tectonic denudation processes and rapid erosion uncovered the uplifted dome.

The thermal event is the best dated of the midTertiary events, and it has some major tectonic implications. Many of the radiogenic and fissiontrack dates of the rocks of the crystalline core, henceforth simply called the core rocks, are 25-28 m.y. old, but at least seven dates are older, and a few are younger. This widespread late Oligocene to early Miocene age is believed to reflect a final rapid uplift that led to the uncovering and consequent chilling of the core rocks to a temperature below about $400^{\circ}$ $450^{\circ} \mathrm{C}$, as proposed by Hedge (1960) and below $100^{\circ}-200^{\circ} \mathrm{C}$ for fission-track ages (C.W. Naeser, oral commun., 1978). Similar ages are obtained from several small quartz monzonite to granodiorite stocks that intrude both the core and the carapace rocks. These stocks typically have a granitoid texture, but in places the texture of the stock margins grades through zones of partly assimilated rock or of hybridized rock into core rocks having gneissic texture (Drewes, 1974 and 1977).

The domical structure of the Rincon Mountains probably formed during early or mid-Tertiary time as a result of an upward-moving igneous mass. The dome is seen to postdate most of the thrust faulting of the cover rocks and to predate or largely predate the age of the final thermal event, or rapid cooling to set the radiometric clocks. This doming may, but need not, have occurred simultaneously with uplift to the dome's present position. Both the cover rocks and the foliation in the core are domed, and in many places the bedding attitudes also are domed. While the Rincon and the Santa Catalina gneiss-cored domes are impressive structural and topographic features when seen on the ground, they are far less impressive in structure section (Drewes, 1980 , sections $A-A^{\prime}$ and $\left.B-B^{\prime}\right)$, for their flanks mostly dip less than $20^{\circ}$. The apparent height of the Rincon structure, then, is more a reflection of its large areal extent than of its steep flanks. The open and symmetrical configuration of the dome suggests that the underlying force that formed it was directed upward. Perhaps 


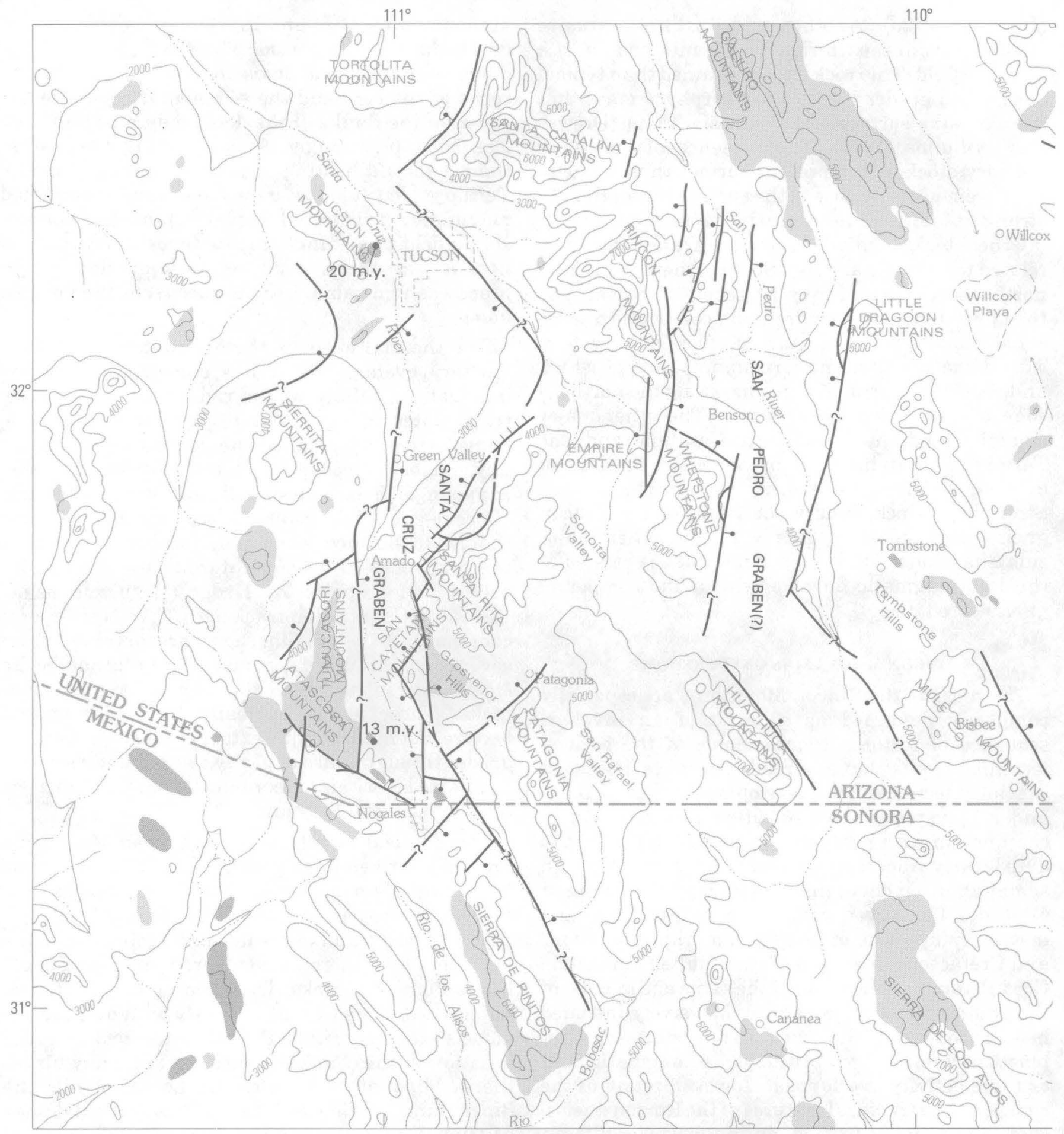

100 KLLOMETERS

a viscous magma moving slowly upward provided the force for doming and the heat for recrystallization of the core rocks, including both the host rocks and older intrusive rocks, to aid in the development of their fabric.

Many small-scale structural features were formed 


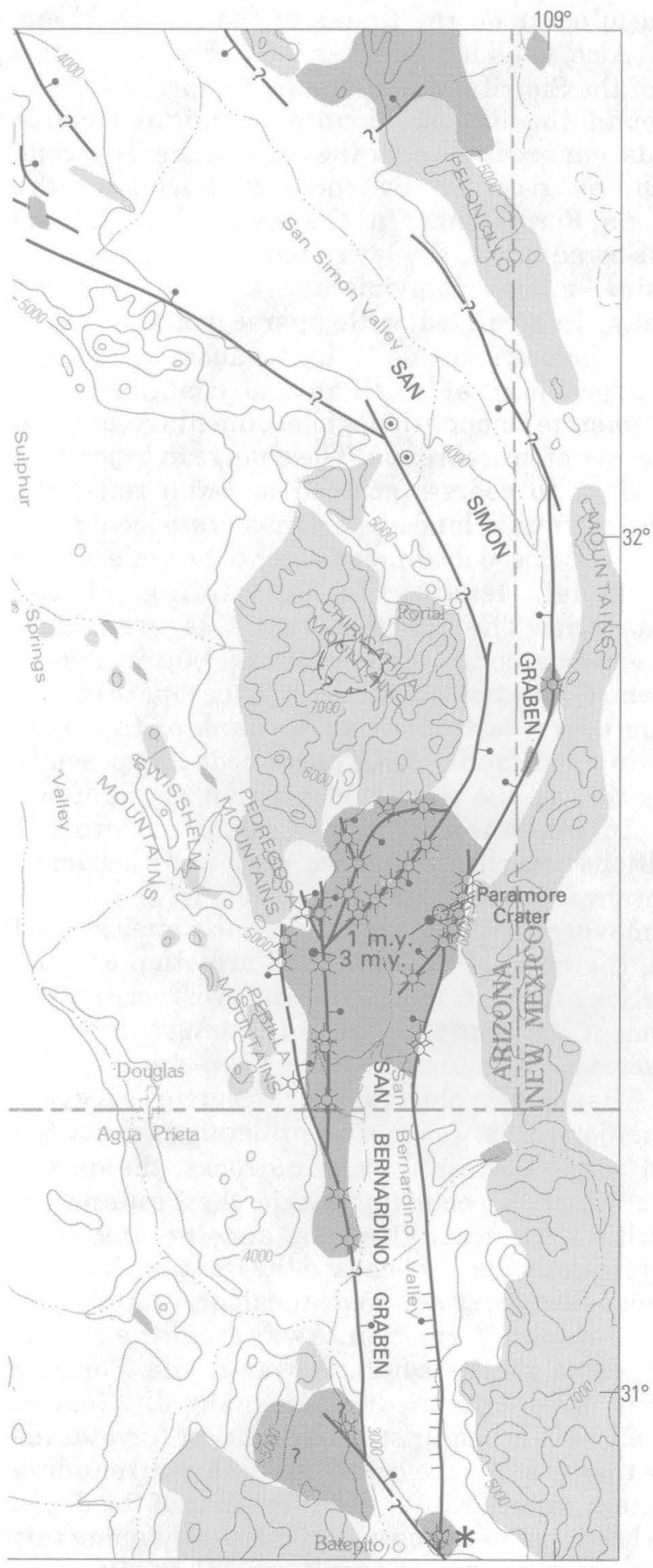

EXPLANATION

PLEISTOCENE AND PLIOCENE BASALTIC ROCKS

MIOCENE AND OLIGOCENE RHYOLITIC ROCKS

- NORMAL FAULT-Bar and ball on downthrown side; hachures show fault scarp. Dashed where inferred in subsurface

ये CINDER CONE

- CRATER OF OTHER VOLCANIC COLLAPSE OR MAAR STRUCTURE

3 m.y. SITE OF RADIOMETRICALLY DATED BASALTIC ROCK AND AGE

- SITE OF SELECTED DRILL HOLE

* epicenter of sonoran earthouake of 1887

FIGURE 4 (left and above).-Basin and Range faults and related volcanic features. Note the influence of the fault system of figure 2 on segments of these faults. Base from Defense Mapping Agency Aerospace Center, scale 1:1,000,000, ONC H-22, edition 8(1969); contour interval $1,000 \mathrm{ft}$.

as a result of gravity-induced movement off the flanks of the dome. Some features, such as tight folds, were formed while the rocks were plastic. Experimental work by H. C. Heard (Turner and

Weiss, 1963, p. 291) showed that limestone can deform ductilely at about $200^{\circ} \mathrm{C}$ and $1 \mathrm{kbar}$ in a short time. Other features, such as breccia sheets, block faults, and fracturing for dike emplacement, indicate 
a more brittle tectonic environment. Probably both conditions existed at separate times in the area of the Rincon Mountains gneiss-cored dome. Even the small folds probably formed during more than one time of deformation, although Davis (1975) believes all of them formed during the Oligocene and younger gravity movement.

Evidence for multiphase tectonic development of the area, with the youngest phase being the Oligocene or younger gravity movement, comes from field relations, from the geometry of features, and from the timing of specific events. These concerns are the subject of a paper outlined by Drewes and Thorman (1978). However, the following examples demonstrate the kind of evidence available to indicate two phases of deformation separated by a substantial span of time. (1) Some stocks dated at 26 m.y. cut low-angle faults, whereas other low-angle faults underlie andesite flows that also are dated as 26 m.y. old. (2) Locally the Pantano Formation of Oligocene and Miocene age lies uncomformably across some low-angle faults; elsewhere the formation overlies other low-angle faults. (3) In many places the Pantano Formation contains abundant clasts of nongneissic Rincon Valley Granodiorite of Precambrian $\mathrm{Y}$ age, which in the Rincon Mountains is known to occur only in a thrust plate in the cover rocks and nowhere in the core rocks. Consequently, thrust faulting predates a period of erosion and deposition, and glide faulting postdates that period. (4) An unfoliated latite porphyry dike cutting strongly foliated and lineated rock of the crystalline core is dated by the fission-track method on apatite and zircon at about $25 \mathrm{~m} . \mathrm{y}$. and $30 \mathrm{~m} . \mathrm{y}$. old, respectively (C. W. Naeser, written commun., 1978). The fabric of the host rock then is $30 \mathrm{~m} . \mathrm{y}$. or older, and since it formed the rock changed from a ductile to a brittle environment.

Tectonic denudation accompanied rapid erosion where the local topography was markedly oversteepened. Processes of tectonic denudation include low-angle normal faulting, gravity gliding, landsliding, and slumping. These processes probably form a sequence, in the stated order, that reflects mainly differences in the size of the masses involved. Rate of movement or degree of freedom of movement are vital factors, too, but they may be dependent to a large extent on the size, and particularly on the thickness of the mass. All these processes occurred under gravitational impetus near the surface where sufficient topographic relief existed. Examples of each of these tectonic denudation processes that were active during mid-Tertiary or later time are found in the southeastern Arizona; all types are be- lieved to occur on the flanks of the Rincon Mountains. Also, a glide plate was identified on the sast side of the Sierrita Mountains by Cooper (1960b).

Around the Rincon Mountains, initial tectonic denudation occurred near the close of the Oligocene Epoch, as recorded by the constituents of the Pantano Formation. On the south flank of the gneiss-cored dome, the lower part of the formation contains much conglomerate and some playa deposits, intercalated with sparse volcanic rocks dated radiometrically as $24 \mathrm{~m}$.y. to about $34 \mathrm{~m}$.y. old. The upper part of the Pantano contains much fanglomerate, monolithologic sedimentary breccia, and lenses of megabreccia. The change in deposition from finer to coarser grained material reflects a transition from a landscape of moderate local relief (possibly a closed drainage basin) to one of extreme local relief, leading to landsliding of the megabreccia. The record of uplift is even more impressive on consideration that the entire mass of Pantano Formation and underlying carapace moved off the upper part of the south flank of the dome following deposition of the playa beds and possibly partly during the time of deposition of the upper beds. In other words, a reversal of topographic conditions occurred: what once was a basin became a mountain in a short time.

In moving off the south flank of the gneiss-cored dome, the mass of the Pantano Formation and the underlying discontinuous sheet of cover rocks slid on a segment of a gently southward dipping older fault, and acted as the hanging wall of a low-angle normal fault. The complex older fault is interpreted to be part of a major thrust fault of Cordilleran age; but the broad zone of sheared Pantano rocks, the disharmonic structure occurring within the Pantano but not within the footwall rocks, and the brecciated mylonite immediately beneath the Pantano indicate that movement was renewed after deposition of some of the Pantano Formation. Away from the gneisscored dome to the south, however, the Pantano Formation is unfaulted or only slightly faulted (Finnell, 1971) against Precambrian crystalline rocks that are like the basement in the surrounding mountain ranges rather than like that of the dome. The absence or near absence of movement along this contact suggests that the fault beneath the Pantano to the north dies out southward; consequently, the hanging wall is a trapdoor-like flap next to the rising dome. While there was differential movement between points on opposite sides of this segment of the two-stage, or complex, fault, the hanging-wall block was the passive one, except for some lateral motion and perhaps even a slight upward movement of a given point as the flap was raised. 
Even though the distal end, or hinge area, of this mass of rock was essentially anchored, the differential movement along the fault on the flank of the dome produced disharmonic faulting within the hanging-wall block. In the main mass of Pantano Formation, these faults are fairly widely spaced compared to those in the cover rocks, which have had a prior history of deformation. Responding to local differential stresses, the rocks within individual blocks of the Pantano were gently to moderately tilted, and in a few places they were also slightly drag folded.

In places, some of the cover rocks and some of the Pantano Formation may have moved off the south flank of the gneiss dome as glide plates. In this case the distal side (the leading or downslope side) of the plate was detached from the underlying rock and did not remain anchored, as in the case of the low-angle normal fault. A shallow structural environment would favor the development of a glide fault. Perhaps, with the gravitational stress extended over a sufficiently long time, some faults that began as low-angle normal faults gradually propagated away from the dome, reached the surface, and became glide faults. The glide plates could have then moved freely over longer distances, and in the process these thin mobile rock masses were apt to be strongly broken internally. As direct proof of complete structural detachment during the mid-Tertiary is not available, several indirect indications are used to infer that glide plates, as well as low-angle normal faults, flanked the gneiss-cored dome. A mass of Pantano and of Paleozoic rocks at Colossal Cave (Drewes, 1977) is surrounded by a gently inward dipping, saucer-shaped fault plane. The rocks overlying this proposed glide fault are more jumbled than the surrounding, structurally underlying rocks; block faulting is common, some blocks are steeply tilted, and wedges of the Pantano Formation have been faulted into the Paleozoic terrane $2 \mathrm{~km}$ northeast of the cave. The Paleozoic sedimentary rocks within this mass have been thrust faulted, but the type and extent of disturbance in the mass also indicates subsequent glide faulting. Conceivably, too, the amount of downslope flowage implied by the many folds in the Horquilla Limestone of this area (Layton, 1957; Arnold, 1971; Davis, 1975, fig. 8A) favors large tectonic transport.

On the west side of the Rincon Mountains, the lowangle fault at the base of the mountains is also overlain by masses of Pantano Formation and cover rocks that have both moved off the upper flanks of the gneiss-cored dome. These masses are less extensive than those on the south flank (Pashley,
1966; Drewes, 1977), and their distal ends are concealed beneath the young alluvial cover in the Tucson basin. One mass, the abundantly faulted rocks of the Bisbee Formation near Loma Alta south of Tanque Verde Ridge, may be an erosional remnant of a glide plate. Another mass, a large body of quartzitic Pinal Schist of a kind still found capping part of the dome, lies above an intensely sheared and folded mass of Paleozoic and Mesozoic rocks near the headquarters of the Saguaro National Monument; the contrast in rock types and the olderover-younger sequence of rock suggest a fairly large amount of movement on a glide fault rather than the more limited movement possible over a low-angle normal fault. Alternatively, this relation may reflect, in part, a local overthrusting during the earlier Cordilleran deformation.

Slump and landslide deposits on the slopes of the Rincon Mountains (Drewes, 1974 and 1977) show that there still is considerable topographic oversteepening. These deposits typically moved on foliation planes, much as the glide plates did, so the slump masses are essentially small-scale glide plates. Slump and landslide masses are more extensive and abundant in the Rincons than in the other high mountains of the region, apparently because of the domal structure and the outwarddipping fault, foliation, and bedding planes, for the local relief on the flanks of the Rincons is only slightly greater than that around the other high mountain ranges. In the Rincons the largest slump field covers an area of about $3 \mathrm{~km}^{2}$ and extends from the crest to the foot of the main ridge southeast of Mica Mountain. Open fractures along the crest and swales behind individual slump masses show that movement is probably still in progress.

\section{OTHER STRUCTURAL FEATURES}

On the east side of the Sierrita Mountains, a large glide plate of mid-Tertiary age was inferred by Cooper (1960b) to have moved north-northwestward about $10 \mathrm{~km}$. Many features of this plate resemble those on the flanks of the Rincon Mountains. The San Xavier fault, which was called a thrust fault by Cooper but is described as a glide fault on the regional compilation (Drewes, 1980), dips gently inward toward the center of the plate and is known through abundant drill-hole data to be an open, concave upward, saucer-shaped surface. Much of the exposed and subsurface part of the glide plate comprises the Helmet Fanglomerate, which contains some volcanic rocks dated at $30.7 \mathrm{~m} . \mathrm{y}$. and some 
megabreccia lenses. These rocks are tilted moderately south-southeast, but are otherwise little deformed. Mesozoic and Paleozoic sedimentary and volcanic rocks, which also form part of the glide plate, are cut by many thrust faults and normal faults and locally are tightly folded around northwest-trending axes. Cooper placed the age of glide faulting as post-Helmet Fanglomerate, and I further suggest that movement may have begun even before the end of Helmet time, or during the late Oligocene, because the fanglomerate contains megabreccia lenses that in themselves indicate that local relief was great and appropriate to induce gliding. Cooper based distance and direction of tectonic transport on tilt of the fanglomerate and probable offset of selected features; movement was away from a high area no longer present, which was probably situated between Amado and Continental along the Santa Cruz Valley. Following denudation, the highland remnants may have been concealed through the downfaulting of the Santa Cruz graben and deposition of alluvium in late Tertiary time. The more intense deformation of the older rocks of the glide plate dates back to Cordilleran thrust faulting; the older structures simply were carried northnorthwestward upon the younger glide fault (figs. 3 and 4).

Block faulting and effusion of volcanic rocks that began during mid-Tertiary time continued at a diminished rate into Pleistocene time. Indeed, an extension of one fault zone $50 \mathrm{~km}$ south into Sonora (fig. 4) was active during historic time, in association with a major earthquake. Late Tertiary faulting occurred in the graben along the Santa Cruz Valley, probably occurred in the graben along the San Bernardino-San Simon Valleys and in the lower reaches of the San Pedro Valley, and may have occurred in other places where there are no known beds of late Tertiary age to mark such events. In a few places, gravity anomalies were used to project segments of these faults on figure 4 beneath concealing younger deposits. The scattered small occurrences of basaltic andesite along the Santa Cruz graben, dated at 13-20 m.y. (Marvin and others, 1973), may be related to this faulting.

A large field of basalt poured out in the San Bernardino Valley during the late Pliocene and Pleistocene and probably was accompanied by block faulting. Cinder cones still retain their conical shape, and a few well-preserved maar structures, such as Paramore Crater, attest to the geologic youthfulness of the field. A lava flow from low in the volcanic pile is dated at $3 \mathrm{~m}$.y., one from near the top is only $1 \mathrm{~m} . \mathrm{y}$. old, and another yields a date of 0.2 m.y., as reported by Lynch (1976). Alined cinder cones suggest the presence of concealed faults that border the graben of the San Bernardino Valley. Other scattered small bodies of basalt lava north of the Swisshelm Mountains and between the Dragoon Mountains and the Tombstone Hills probably mark the concealed sites of bleeding fault zones, ones along which magmas have moved. The youngest faults in the region, along the Santa Cruz Valley, cut gravels of Pleistocene age and a soil that probably developed during the Sangamon Interglaciation on the northwest side of the Santa Rita Mountains (Drewes, 1971a and 1972b).

\section{MAJOR STRUCTURAL FEATURES}

The major structural features successively developed in southeastern Arizona are a northwesttrending system of complex faults, northeastdirected thrust faults, and northerly trending Basin and Range block faults. The foregoing analysis of the tectonic development of southeastern Arizona is supported by a review of the geometry, dynainics, and age of fault movement of these major structural features. In part, the review is summarized graphically on a geologic map with accompanying structure sections (Drewes, 1980). Further descriptions and interpretations are presented in this part of the report.

\section{NORTHWEST-TRENDING SYSTEM OF COMPLEX FAULTS}

The northwest-trending fault system of southeastern Arizona consists of widely dispersed segments of vertical faults, along which movement has been recurrent and diverse. In some places the fault segments are discrete and fairly narrow features, but in others they are broad zones of sheared rock and closely spaced individual fault planes. More commonly, the faults are intruded by igneous rocks or are covered by younger volcanic or sedimentary rocks. As a result, previous studies of these faults have led to diverse interpretations and to controversy.

Some complex, broad, northwest-trending shear zones have been the basis for the projection into southeastern Arizona of the Texas lineament of Hill (1902), Ransome (1915), Albritton and Smith (1957), and Mayo (1958) and, more vaguely, for the projection of other lineaments of California and Nevada. The Texas lineament is most often considered to be a right-lateral strike-slip composite 
fault mainly of Tertiary age. Exceptionally, Moody and Hill (1955) inferred major left-lateral movement, and Baker (1935) and Albritton and Smith (1957) first suggested and substantiated that movement occurred as early as the Precambrian. Kelly (1955) further suggested that the lineament consists of a zone of en echelon faults. Should such a zone extend from west Texas to southern California, then the evidence from southeastern Arizona would favor the concept of a swarm of en echelon faults, with a large amount of left-lateral movement as well as other kinds of movement, which were active probably as early as the Precambrian and certainly from the Triassic to the late Tertiary. Very likely these faults are surface expressions of an ancient system of flaws in the crystalline basement that were reactivated at various times and in response to various stresses, to produce an array of field relations. Apparently, the diversity of these relations has contributed to the controversy on the nature and origin of the fault system. Because I am reluctant to project this tectonic interpretation from part of southeastern Arizona far beyond the region without supplementary studies elsewhere, the term Texas lineament is not applied in this study. The faults will simply be referyed to as the northwest-trending complex fault system.

\section{GEOMETRY OF THE FAULTS}

In a general way, the northwest-trending complex fault system breaks up the rocks into vast upended slabs and lozenge-shaped blocks that mostly strike N. $40^{\circ}-60^{\circ} \mathrm{W}$. The faults that separate these blocks branch and merge in a manner typical of the much smaller individual shear planes of many fault zones, which are especially common in strike-slip fault zones. Both the great width and the length of some segments of fault zones in the region suggest that they are master faults, as for example the Mogul-Apache Pass fault zone and the Sawmill Canyon-Kino Spring fault zone. Less conspicuous subparallel faults lie between and adjacent to these master faults. Still more subordinate faults splay off the master faults, most typically on the convex side of minor bends in the trace of these faults. Thus, branch faults splay to the north off a gently curved segment of the Apache Pass fault zone in the Dos Cabezas and Chiricahua Mountains (fig. 2) that is concave to the southwest. Similar faults splay off to the south from a slightly arcuate segment of the Sawmill Canyon fault zone in the Santa Rita-Huachuca Mountains area that is concave to the northeast. Splay faults of this sort are common features of known strike-slip faults in other regions.
The trace of the Apache Pass fault is discontinuously exposed along a $35-\mathrm{km}$-long belt extending approximately between the villages of Dos Cabezas and Portal in the Dos Cabezas and Chiricahua Mountains (Sabins, 1957a; Cooper, 1960a). Along this belt the fault trace is slightly arcuate, convex to the northeast. In some places it is marked by a single fáult plane or very narrow zone; elsewhere, as east of Dos Cabezas and also east of Red Mountain (pl. 3), it forms a broad zone between two or more major strands. Near Dos Cabezas and near Red Mountain, branches of the fault splay off to the north; the Emigrant Canyon fault of Sabins is one of the largest of these branches. Along both the main fault branches and some of the splay faults there are scattered fault slivers or horses of rock typically older than the adjacent wall rock. For instance, east of Dos Cabezas there are several slivers of Paleozoic limestone wedged into Upper Cretaceous volcanic rocks. Slivers of such limestone also occur along Emigrant Canyon, variously between Precambrian granitoid rock and Lower Cretaceous sedimentary rock or Tertiary igneous rock.

Beyond this well-exposed belt to the southeast, the Apache Pass fault is concealed first beneath the alluvium of the San Simon Valley and then beneath mid-Tertiary volcanic rocks of the Peloncillo Mountains, and to the northwest it is concealed first beneath alluvium of the Sulphur Springs Valley and then beneath mid-Tertiary volcanic rocks of the Winchester and Galiuro Mountains. Beyond the Galiuro Mountains the fault may emerge once again in the north end of the Santa Catalina Mountains as the Mogul fault.

The Kelsey Canyon fault at the north end of the Johnny Lyon Hills (Cooper and Silver, 1964) and the unnamed northwest-trending fault at the southern end of the Winchester Mountains (fig. 14; Creasey, Jackson, and Gulbrandsen, 1961; Cooper and Silver, 1964) may be segments of faults branching off the Mogul-Apache Pass master fault. A southeastward extension of the Kelsey Canyon fault may produce the offset of formations across the gap between the Steele and Redbird Hills, but the further projection of this fault, as well as of the unnamed fault of the Winchester Mountains, beneath the surficial deposits of the Willcox Playa area of the Sulphur Springs Valley is uncertain. However, southeast of the playa and along the northeast side of the Swisshelm Mountains are several alined igneous masses, which may have been emplaced along a concealed northwest-trending fault. These igneous masses include a few isolated small flows of basalt 
intercalated in Pliocene-Pleistocene gravel; they also have alined rhyolite plugs. Segments of a large north-northwest-trending fault are exposed farther southeast in the Pedregosa Mountains. Together, these features may mark the presence of an extensive and slightly arcuate master fault that is subparallel to the Mogul-Apache Pass fault.

In the next mountains north of the Dos Cabezas Mountains, Swan (1975) reported another major northwest-trending fault that had at least $6 \mathrm{~km}$ of left-lateral movement during Precambrian time.

A fault that is very poorly exposed is believed to trend subparallel to the Kelsey Canyon and Apache Pass faults, passing through the gap between the Tombstone Hills and the Dragoon Mountains, and cutting across the pediment north of the Whetstone Mountains. A steep gravity gradient in the Tucson basin striking northwest of Vail (West and Sumner, 1973) may be an expression of the extension of this inferred fault to the northwest, and the scarp along the northeast flank of the Mule Mountains may mark the extension to the southeast (fig. 2). At Tombstone, three lines of evidence suggest the existence of such a fault: (1) mid-Tertiary volcanic rocks are juxtaposed with Paleozoic rocks; (2) a deep alluvial basin is restricted northeast of a line of outcrops that trend toward the northeast tip of the Whetstone Mountains; and (3) an isolated basalt flow, which may have been extruded along such a fracture, occurs in gravels $1 \mathrm{~km}$ east of Tombstone. Spangler (1969) also inferred the presence of a concealed fault and of an intrusive mass along the fault from a gravity study in the Tombstone area.

A better exposed major member of the northwesttrending system is the Sawmill Canyon fault. In the Santa Rita Mountains the fault forms a narrow sheared zone to the northwest and flares out to the southeast (Drewes, 1971a, 1971b, and 1972a). Several southeast-trending strands branch off the fault, along the east flank of the Santa Rita Mountains and in the adjacent Canelo Hills (R. B. Raup, written commun., 1968): The main fault then is seen to trend eastward in two main branches-one, the Babocomari fault, across the southern end of the Mustang Mountains, and the other, the Kino Spring fault, across the northern end of the Huachuca Mountains (pl. 6; Hayes and Raup, 1968; Drewes, 1980). These branches merge again near the gap between the Mule Mountains and the Tombstone Hills (fig. 10; Gilluly, 1956), and possibly the single strand then extends to the southern Swisshelm and Pedregosa Mountains (pl. 5 and fig. 7; Epis, 1956; Cooper, 1959). Both east of the Mule Mountains and in the Pedregosa Mountains, later movement of segments of other faults of the northwest-trending system cut this stray east-trending branch of the Sawmill Canyon fault system. In the Mule Mountains, another major branch of the fault splays off to the southeast, where a part, near Bisbee, is known as the Dividend fault (Ransome, 1904, and Hayes and Landis, 1964). It has been projected by Ludano Lucarelli (1967) $25 \mathrm{~km}$ into Sonora on the basis of studies of aerial photos.

Northwest of the Santa Rita Mountains the Sawmill Canyon fault is concealed beneath alluvium and possibly also by the San Xavier glide plate near the Sierrita Mountains. It may then lie beneath gravel deposits along a zone of strong gravity gradient on the southwest side of the Tucson Mountains (West and Sumner, 1973) and connect with the northwest-trending structures of the Silver Bell Mountains (Richard and Courtright, 1966). Several short segments of northwest-trending faults also cut the rocks of the northern part of the Santa Rita Mountains (Drewes, 1972a).

The Santa Rita-Harshaw Creek fault (Drewes, 1980 ) is another member of the northwest-trending system that is obscure. The continuity of this fault is interrupted by many intrusive bodies, however, rather than by extensive younger cover. In the Santa Rita Mountains, so much of the fault is intruded that the term "fault scar" is applied (Drewes, 1972a), with the implication that the original fracture has been largely obliterated or "healed" by the intruding magma. In the Santa Rita Mountains, Triassic volcanic rocks were upended and faulted before Upper Triasssic intrusive rocks were emplaced. The volcanic rocks are preserved as alined inclusions and septa in Jurassic and Upper Cretaceous stocks, which in plan form prong-like protuberances or straight borders along the old fault line. The upended Triassic rocks extend southeastward into the Patagonia Mountains along the Harshaw Creek fault (Drewes, 1980). Subparallel to this fault, and connected to it by several crossfaults, is the Guajalote fault (Simons, 1974), which appears to have controlled the northeast border of a large stock of Paleocene age. Extensions of these faults are recognizable on aerial photographs into adjacent parts of Sonora, where they trend toward the geologically complex and much intruded area at Cananea. Northwest of the Santa Rita Mountains, the fault scar is projected to the northeast flank of the Sierrita Mountains (Cooper, 1973), where a septum of Precambrian granodiorite separates the Ruby Star stock of Paleocene age on the west from a similar stock on the east. Perhaps this old fault merges with 
the extension of the Sawmill Canyon fault southwest of the Tucson Mountains.

Another northwest-trending complex fault system along the west flank of the Sierrita Mountains (Drewes and Cooper, 1973) presents an apparent conflict. The shingling of Paleozoic and Mesozoic rocks suggests an episode of thrust faulting along this zone, but the subhorizontally oriented stretched pebbles in some formations in the fault zone permit the inference of strike-slip movement along it. The remarkably abrupt southeastern termination of this conspicuous fault zone is inferred to be related to a major northeast-trending complex structural feature, the Sierrita line, which is described in the section on thrust faults. Because the area is metamorphosed and abundantly intruded, some major questions about the development of this fault zone remain unanswered, such as whether the stretched pebbles represent an $a$ or $c$ lineation. Should the lineation be of the $c$ type, there would be no conflict.

A totally concealed northwest-trending flaw in the basement rocks is believed to extend from the Silver Bell Mountains at least as far southeast as the Tombstone Hills. This structural feature is marked solely by an alinement of six small stocks 70-74 m.y. old; no other stocks of this age are known in the region. The stock of this group in the Silver Bell Mountains is actually given radiometric dates of 64-65 m.y., but these dates are probably not true emplacement ages because, according to Richard and Courtright (1966), the stock is older than volcanic rocks that are dated as $70 \mathrm{~m}$.y. old. The age of the volcanic rocks is corroborated by many similar radiometric dates obtained from correlative rocks of the Silver Bell-Cat Mountain-Salero suite (fig. 2). Thus, the age of the stock in the Silver Bell Mountains is probably also $70 \mathrm{~m} . y$. old or older.

The dip of the faults of the northwest-trending system is everywhere seen to be steep, if not actually vertical. Most commonly the steep attitude is simply shown by the trend of the trace of the fault, or a strand of the fault, across a ridge or canyon. Locally, dip values are directly measurable on shear planes. Equally informative are the attitudes of slabs of rock included as horses along faults. Most dip values are $70^{\circ}$ or more; few are less than $60^{\circ}$.

\section{DYNAMICS OF THE FAULTS}

Both vertical and horizontal movement is inferred along segments of the northwest-trending faults, and some of the left slip may be large. Typically, only stratigraphic offset can be identified, and in places even that is inferred. A case in point is the interpretation that the northeast side of the Sawmill Canyon fault in the Santa Rita Mountains was raised several times, for a total vertical displacement of several thousand meters (Drewes, 1971c); this movement was inferred from the depositional record of coarse fanglomerate wedges on the southwest block. Vertical offset is also indicated along the easttrending segment of the Sawmill Canyon fault, where a block of mid-Tertiary rocks was dropped graben-like between the Babocomari and Kino Spring fault branches. An offset of the mid-Tertiary volcanic rocks along the Apache Pass fault east of the Chiricahua National Monument is also attributable to normal movement (Sabins, 1957a). But in all three examples cited here, possible lateral movement is also indicated.

Strike-slip movement is demonstrable in some places and is suspected in others. In a few places, oblique-slip striae are indicative of a late composite direction of movement. More significant are drag features along faults, such as those along the Kino Spring fault and small splay faults and other related faults (pl. 6). Disharmonic folds that have amplitudes of a few tens of meters and that plunge obliquely into the fault are believed to be effects of strike-slip movement (pl. 7 and fig. 13). Where postfault dikes are deflected in trend near a fault, they probably have followed curved fractures formed under strike-slip stresses, as along the main zone of the Sawmill Canyon fault. Likewise, a horizontal offset of genetically related thrust sheets without comparable offset in underlying rocks suggests tear fault movement, as is interpreted in the Helvetia District (Drewes, 1972a, pl. 4). Probably much strikeslip movement occurred to offset the thrust faults of the Marble Canyon area along the Emigrant Canyon fault (Sabins, 1957a; and this report, section on northern Chiricahua Mountains and pl. 3). Strikeslip structures are also suggested by the occurrence of numerous fault slivers (especially those comprising rock older than both adjacent blocks) and of systematic splay faults. Ample evidence shows that much of the movement on the northwesttrending system is strike-slip, and the evidence of drag and offset is consistently left lateral.

Evidence to permit inferences of the amount of movement is sparse, and at best gives a fragmentary story. In the Santa Rita Mountains, a few thousand meters of left-lateral movement was inferred in connection with Paleocene movement on the subsidiary faults of Helvetia (Drewes, 1972a). In the Marble Canyon area of the northern Chiricahua Mountains, I estimate the amount of left-lateral movement on the Apache Pass fault to be $10-15 \mathrm{~km}$. 


\section{AGE OF COMPLEX FAULTS}

Taken segment by segment, the evidence of age of movement on the northwest-trending faults presents a confusing picture, but taken collectively, the evidence provides a consistent picture of an old, longlived, and often reactivated fault system. There are hints of movement during the Precambrian and clearcut signs of movement during the Triassic to Early Cretaceous, reactivation during the Paleocene in connection with the late Cordilleran orogeny, and movement of mid-Tertiary age. Possible Precambrian movement is suggested by the occurrence of tightly folded Precambrian quartzite immediately southwest of the Apache Pass fault near Bowie Mountain (pl. 3; Drewes, 1980). The folds plunge steeply southward and are oblique to the fault. Neither this type of fold nor the Precambrian quartzite is present northeast of the fault, where other Precambrian rocks are amply exposed. Accordingly, and inasmuch as Paleozoic rocks are unaffected by this folding, I view the folds as possible drag structures formed in response to Precambrian strike-slip movement on the Apache Pass fault. Precambrian movement was inferred by Swan (1975) on another of these faults northeast of Willcox (fig. 2).

Precambrian age of movement on a fault related to the controversial Texas lineament was first suggested in Texas by Baker (1935) and was supported by Albritton and Smith (1957), who pointed out the sparse distribution of thick and coarse deposits of locally derived conglomerate in Precambrian formations.

Triassic movement is inferred along the Sawmill Canyon fault and the Santa Rita fault scar in the Santa Rita Mountains (Drewes, 1972a, p. 27-29). Some evidence is based on the sedimentary record of rocks near a major fault, and other evidence is based on geologic relations between older Triassic volcanic rocks and younger Triassic intrusive rocks. Faulting of early Mesozoic age probably also occurred on the Dividend fault near Bisbee, where the thick Paleozoic sequence was removed as a result of the uplift and erosion from the nearby part of the northeast block before Lower Cretaceous rocks were deposited. Nearby, the Jurassic Juniper Flat stock appears to have had a structurally controlled southwestern margin, and so a fault with an early movement phase is inferred to have been intruded. The Santa Rita fault scar and other faults in the allochthon that show no post-thrust-fault movement were transported into the area from the southwest.

Early Cretaceous movement along the Sawmill Canyon fault is implied by the presence in a pre-
Bisbee sequence on the southwest side of the fault of wedges of coarse fanglomerate that thicken toward the fault but do not appear beyond it. These conglomerate wedges contain clasts derived from the opposite side of the fault (Drewes, 1971c). A small amount of movement also occurred on the Dividend fault in Late Cretaceous or early Tertiary time, as is shown by offset of the Bisbee Group; the upper age limit for this movement is set by some plugs of midTertiary or older age that were intruded into nearby, probably genetically related, faults.

Fault movement of early Tertiary age, and in some places specifically of Paleocene (late Cordilleran) age, is recorded along parts of the Apache Pass fault and on the small faults associated with the Sawmill Canyon fault. In the northern Chiricahua Mountains a thrust fault of Late Cretaceous age is inferred to be offset along the Emigrant Canyon fault (this report, pl. 3; Sabins, 1957a), which branches off the Apache Pass fault. Similarly, the thrust fault is believed to be offset along the main strand of the Apache Pass fault in this area (this report, fig. 2; Drewes, 1980). Nearby, the intrusion of three stocks, 30-34 m.y. old, into the Apache Pass and related faults sets an upper age limit of this episode of faulting. In many other places, rocks of Cretaceous age are offset along the northwest-trending faults, but, in the absence of Tertiary rocks, no upper limit to the time of movement can be established.

Faulting also occurred during mid-Tertiary or late Tertiary time along a few segments of these faults. For example, east of the Chiricahua National Monument, volcanic rocks of late Oligocene and early Miocene age are dropped down against Paleozoic rocks along a segment of the Apache Pass fault. This movement followed a time when the northeastern block was uplifted, during which time the Paleozoic and Mesozoic rocks were eroded from the Precambrian granodiorite before the Tertiary volcanic rocks were deposited. Young faulting is also inferred from the offset of volcanic rocks of midTertiary age along the several inferred and exposed northwest-trending faults east of Tombstone. The graben of mid-Tertiary sedimentary rocks between the Babocomari and Kino Spring branches of the Sawmill Canyon group of faults is another youthful segment of the northwest-trending system.

Perhaps the most recent activation of segments of the northwest-trending complex faults occurred in the Pajarito and Atascosa Mountains near Nogales (fig. 14). Pliocene-Pleistocene gravels are offset along a northwest-trending fault that may be part of a northwest-trending structure in the basement, reactivated as a Basin and Range structure. The 
Basin and Range type of faults a few kilometers northeast of Nogales may also have been controlled by a fault of the northwest-trending system. Likewise the postulated normal faults northeast of the straight scarps of the Mule Mountains and the Dos Cabezas Mountains may have been guided by earlier flaws.

\section{NORTHWEST-TRENDING FAULTS AS GUIDES} TO MOVEMENT OF FLUIDS

The northwest-trending fault system has had a recurring and major influence on the movement of magmatic and mineralizing fluids. In the section on the geometry of these faults, the influence of the fault system on the emplacement of stocks of Triassic to Paleocene age has already been shown, but the record of association is still more extensive.

The volcanic rocks of the Silver Bell-Cat Mountain-Salero suite are shown on figure 2 in relation to the northwest-trending structures. With very few exceptions, these volcanic rocks occur near the faults. Those exceptions in the Roskruge Mountains are of uncertain significance because very few older rocks are present in which remnants of a fault may be found. The ages of 69-73 m.y. obtained for these volcanic rocks suggests a genetic association with the stocks 70-74 m.y. old alined on the postulated concealed northwest-trending fault. And indeed, fields of these volcanic rocks do occur near many of the stocks.

The northwest-trending fault system seems to have provided the main conduits for mineralizing fluids of most of the large ore bodies in southeastern Arizona. While few of these faults are themselves mineralized, all large and most medium-sized mining districts are found within a few kilometers of one of the northwest-trending faults. In many districts the second-and third-order faults appear to have channelled mineralizing fluids away from the master faults, and local mineralization was there controlled by chemically favorable or physically suitable host rocks.

At Bisbee the Dividend fault appears to be such a master fault, which, along a sheath of intrusion breccia of apparent Jurassic age around the Sacramento Hill stock, would have been particularly suitable as a conduit. Second-order faults trending southwest from the chief conduit funneled off the fluids and provided access to the favored host rocks of the upper part of the Abrigo Formation, the Martin Formation, and the lower part of the Escabrosa Limestone (Ransome, 1904; Trischka, 1938). The distribution of types of mineral is inadequately known to provide clues of direction of movement of the fluids; but the deposits are richest close to the Dividend fault, and they decrease in grade southwest and south away from the fault and stock, suggesting a component of movement in those directions.

At Tombstone the distribution of the mineral types suggests that fluids cooled and probably moved from northeast to southwest (Butler and others, 1938) along faults that I believe to be second-order features of the adjacent concealed master fault, which acted as the chief conduit at depth. The nearby isolated body of basalt lava probably also reached the surface along this master fault in Pliocene-Pleistocene time: More locally, ore controls include fold crests and carbonate beds in metamorphosed Bisbee Formation or Horquilla Limestone.

The association of mineral deposits with the northwest-trending faults has been previously recognized, although most studies have focused either on single districts (as have those cited in this section) or on subcontinental-sized regions (Mayo, 1958; Schmitt, 1966; Guilbert and Sumner, 1968). Figure 2 shows the location of 26 major mines or mining camps along these faults. Projecting such master faults, which have guided fluid movement, beneath areas of pediment gravel or other cover could form the basis for a directed geophysical and perhaps also geochemical study in search of specific targets of economic potential.

\section{THRUST FAULTS}

Compressive deformation resulted in the development of widespread thrust faults. Large-scale thrust faulting is shown indirectly by a regional consistency in structural style and age and by local evidence of large distances of tectonic transport. The lowest thrust fault separates an autochthonous terrane from an allochthonous terrane in the northeastern part of the region. Typically, the allochthonous terrane was compressively deformed by folds, thrust faults, and tear faults, while the autochthon was unaffected or only slightly affected by such stress. Within the allochthon some zones of rock are more severely deformed than others. Some of the more severely deformed rocks lie along major thrust faults, and others may reflect a gradual increase in confining pressure to a point where the style of deformation changed. There is no evidence, however, of more than one episode of regional compressional deformation during Phanerozoic time; this type of deformation occurred only during the Piman phase of the Cordilleran orogeny.

The interpretation of regional thrust faulting of Cordilleran age in southeastern Arizona deserves 
careful scrutiny, both because the concept is new and because such interpretations are difficult to establish even in regions of better exposures and fewer tectonic complications than occur in Arizona. In essence, the concept of regional thrust faulting in southeastern Arizona is a working hypothesis rather than an established fact. Consequently, it is presented in considerable detail in the following sections on thrust-fault geometry, style, direction of tectonic transport, amount of transport, and age of faulting.

A brief review of the kind of evidence that has been used to support interpretations of large-scale thrusting in other regions of the Cordilleran orogenic belt will best illustrate the difficulties that beset any such hypothesis. In the foreland thrust belts of Alberta, Montana, and Wyoming, where the search for oil has provided the economic impetus for deep drilling, drill holes that have penetrated allochthons have yielded evidence corroborating the interpretations of extensive plate movement inferred by Price and Mountjoy (1970); Bally, Gordy, and Stewart (1966); Mudge (1972); and Rubey and Hubbert (1959). In Nevada, Roberts and others (1958) inferred that the juxtaposition of diverse sedimentary facies shows a large amount of transport along the Robert Mountains thrust fault of Late Devonian-Mississippian age. In Utah, Crittenden (1961) used the amount of offset of stratigraphic isopach lines of selected Paleozoic formations to estimate a major telescoping of thrust plates on Laramide faults. However, in southeastern Arizona these kinds of evidence are unavailable and, moreover, they may not be available for a long time, because the geologic situation there differs from those of the other regions. The necessity of seeking other kinds of evidence is illustrated by the difficulties in using isopach maps or similar compilations based on stratigraphy to measure tectonic offset in regions of complex tectonic history, such as southeastern Arizona.

In order to develop stratigraphic controls of tectonic offset, there is a need for (1) consistently recognizable field criteria to provide isopach, isofacies, or other isopleth lines; (2) an established gradient of these lines (the gentler the gradient, the more extensive the data base must be); (3) a sufficient number of data points to fix the position and orientation of the lines; and (4) a suitable divergence of the isopleths from direction of transport on a postulated fault. Implicit to some extent in items (3) and (4) is the requirement that (5) the data base must be appropriately oriented with respect to the fault. $A$ northwest-trending fault, for instance, is difficult to test for offset of isopleths where the data base also lies in a northwest-trending zone.

In southeastern Arizona, Hayes (1972) attempted an isofacies evaluation using certain Cambrian formations; but the widely spaced data points in his study do not permit an unequivocal answer, and the orientation of his isopleths could vary $30^{\circ}$ in either direction from those he constructed. Other studies of this sort have the additional weakness of being based on stratigraphic data in the literature, which is inadequate for this purpose. Isopleth data are generally not available, so no isopleth gradients can be established. In Paleozoic rocks, isopleths probably trend northwest parallel to the miogeosynclinal margin of the southwestern flank of the North American craton. The data-base area also is elongate northwesterly, lying between the cover of younger rocks of the Colorado Plateau to the northeast and the extensive bolsons and coastal plains of Sonora to the southwest. Finally, attempts to test northeastward thrust transport by offset or telescoped isopleths also must take into account the effects of left-lateral post-thrust movement on the many northwest-trending complex faults, and few of the major structural blocks between these complex faults have enough unmetamorphosed and unfaulted Paleozoic sequences to provide the requisite control.

Because of these difficulties in using isopleth lines to infer large-scale thrusting, it is necessary to seek other kinds of evidence based on consistent style of deformation, consistent direction of tectonic transport, consistent age of thrusting, and the large amounts of transport implied by the extent of duplication of formations in juxtaposed thrust plates. Another approach involves the possible offset of a beheaded part of a Jurassic stock from its root, but this notion cannot be adequately assessed without better controls on the chemical and mineralogical changes that may be projected up or down a stock. Despite the weaknesses of this sort of evidence, it consistently supports the hypothesis of regional thrust faulting, and it thereby suggests that the Cordilleran orogenic belt is uninterrupted between southern Nevada and northeastern Chihuahua (Drewes, 1976c and 1978).

\section{GEOMETRY OF THE THRUST FAULTS}

In the face of many local structural complexities, the continuity of the thrust faults is inferred with substantial aid from my present understanding of the regional geological history. Without consideration of both the older and the younger faults, 
the segments of thrust faults that have long been recognized in many mountain ranges of southeastern Arizona remain isolated enigmas of the geologic development of the region. But with such consideration, most of the low-angle or beddingplane faults are consistent with an interpretation of a single event of regional thrust faulting. At the same time, the regional geologic history is not the only guide used to interpret the origin of a low-angle fault, for there have been local departures from the regional development. For instance, some uplifts affect only one or a few mountain ranges, and gravity-propelled sheets have moved off some of these high areas. Similarly, particular complications of some areas of low-angle faulting are spatially and probably also genetically related to the emplacement of stocks. But all told, the use of geologic history as a guide to interpreting the association and correlation of many of the low-angle faults has proved to be vital to the regional synthesis. This approach of pyramiding one group of interpretations upon another will doubtless provide the stimulus for further scrutiny, reinterpretation, and modification of the tectonic model presented herein. And that is as it should be.

The thrust faulted terrane forms two major lobes (fig. 5) separated by a belt of complex structures that is basically a tear fault, but which has been modified by some younger faulting and has been largely concealed by younger deposits. The tear fault and related features along its trace, herein named the Sierrita line, extends northeastward from the south flank of the Sierrita Mountains; across the southern spur of the Rincon Mountains, to a point near the middle of the Johnny Lyon Hills about $20 \mathrm{~km}$ northeast of Benson. The Sierrita line will be described with other tear faults after the distribution of the major thrust faults is outlined. The southeastern lobe, then, lies southeast of the Sierrita line and south of the line that extends from the point in the Johnny Lyon Hills eastward through the Apache Pass area between the Dos Cabezas and Chiricahua Mountains and into New Mexico. Corbitt and Woodward (1970) suggested that a similar allochthon extends eastward from there toward El Paso, Tex. The southeastern allochthon thence swings southward into Chihuahua, forming a huge lobate front, convex to the northeast. A major allochthon was recognized in northeastern Sonora by Claude Rangin (written commun., 1975). In the northern part of the Santa Rita Mountains of southeastern Arizona, crystalline rocks of the autochthon appear in a fenster. Further control on the position of the base of the allochthon is unavailable in the region, so its position can only be

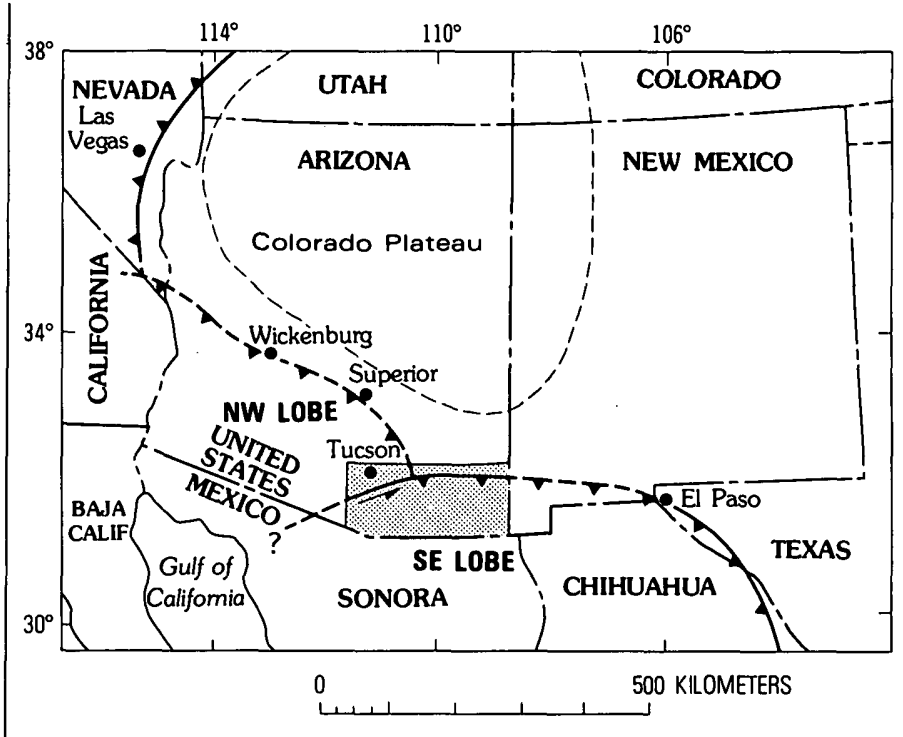

FIGURE 5.-Projected regional distribution of the major thrust plates. Study area stippled.

inferred from the indirect evidence provided by thrust plates at higher structural levels.

The northwestern allochthon lies northwest of the Sierrita line and west of a line that extends from the above-mentioned point in the Johnny Lyon Hills along the valley of the San Pedro River to the vicinity of Superior. Systematically oriented features of compressive deformation are common in the allochthon, in a belt extending from the west flank of the Johnny Lyon Hills and the San Pedro River valley southwest across parts of the Rincon, Tucson, and Sierrita Mountains. These features include large, moderately tight folds, thrust faults, and tear faults that are related to folds or thrust faults. Except for a few open flexures, such structural features are absent in the main part of the Johnny Lyon Hills and the many other ranges northeast of the San Pedro River valley. Glide faults and folds related to local disturbances of Tertiary age do occur in both allochthonous and autochthonous regions, but they are not part of the regional systematically oriented features. From the vicinity of Superior, the extensively concealed thrust front presumably swings westward toward Wickenburg, to form an allochthonous sheet lobate to the northeast. A prong of crystalline rocks of the autochthon extends from the Johnny Lyon Hills to the core of the Rincon Mountains and beyond them to the Santa Catalina and Tortolita Mountains (fig. 3). Some of the autochthonous crystalline rocks of the east flank of the Sierrita Mountains may be exposed through another fenster, or possibly in an offset part of the same window described in the northern part of the Santa Rita Mountains. 
The lobate frontal edges of both of the allochthons are considered to be mainly erosional edges of sheets that were once more extensive. The northeasternmost faults are parts of a sole fault at the base of allochthons, rather than the ramping part of a "sledrunner" fault marking the frontal edge of the allochthon. Irregularities are thus expected in the lobate aspect of the allochthons.

Typically the allochthon overlies the autochthon, but in a few places exceptions occur. East of the San Pedro River and within the area studied, some rocks of the allochthon are seen to underlie a portion of rocks typical of the autochthon of the Johnny Lyon Hills. I view this enigmatic feature as a locally underthrust wedge of allochthonous material beneath a para-autochthonous flap. The upwedging effect of this proposed local underthrust has produced a strong system of faults in the structurally overlying rocks to the east (Cooper and Silver, 1964; Drewes, 1980). Certainly, to the west of the river, the more normal relationship of overthrusting holds, and very likely this relationship also holds northwestward down the San Pedro Valley. Perhaps this local underthrusting is genetically associated with the separation of the (late?) movement of the two lobes; the increased friction of the underthrust wedge may have hindered the movement of part of the northwestern allochthon.

The allochthonous rocks of each of the lobes are broken into major thrust plates; additional deformation within the major plates was less than that between the plates (this report, fig. 3; Drewes, 1980). Two major plates are recognized in the southeastern lobe: a lower one that is here referred to as the Hidalgo thrust plate (overlying the Hidalgo thrust fault) because it extends far to the east across Hidalgo County, N. Mex., and an upper one that is here called the Cochise thrust plate (overlying the Cochise thrust fault) because it is widely recognized in Cochise County, Ariz.

The erosional northern edge of the southeastern lobe of the allochthon is the trace of the Hidalgo thrust fault. This fault separates a thrust faulted and folded terrane to the south from a much less deformed terrane to the north. Several segments of this fault have been recognized in previous, more local studies of the Chiricahua, Dragoon, and Little Dragoon Mountains, and some segments have local names. These names remain useful ties to the literature and may be handy in the event that alternative interpretations arise to the correlation of faults proposed in this study. In easternmost Arizona the Hidalgo thrust fault is inferred to cross the northern part of the Chiricahua Mountains, where it dips moderately to the southwest and is offset by two branches of a major left-lateral strikeslip fault, the Apache Pass fault (pl. 3). Between the San Simon Valley and the more eastern branch of the strike-slip fault system, Sabins (1957a) described this extension of the Hidalgo fault as the Wood Mountain thrust fault (pl. 3). Between the two branches of the strike-slip fault, he applied the name Marble Canyon fault, because he felt that the fault there may have been a different feature. As a result of additional mapping around Marble Canyon, I have interpreted the structures to be parts of a single fault. In the southwestern block of the Apache Pass fault (Drewes, 1980), the Hidalgo thrust fault is seen to extend to the edge of the Sulphur Springs Valley, and from there it is projected northwestward beneath the surficial deposits to some small outcrops of Horquilla Limestone lying adjacent to an unbroken belt of Cambrian-Ordovician rocks near the village of Dos Cabezas (Cooper, 1960a).

West of the Sulphur Springs Valley in the Little Dragoon Mountains, the Hidalgo thrust fault is seen to be the lowest flat-lying large thrust fault mapped by Cooper and Silver (1964). On the southeast side of the mountains, the thrust fault is first intruded by the Texas Canyon stock, dated as 50-52 m.y. old, and then is offset markedly to the east by an eastnortheast-trending fault that separates the Little Dragoon Mountains and the Gunnison Hills from the Dragoon Mountains. The Hidalgo thrust fault is presumed to underlie the northern part of the Dragoon Mountains, which is intensely thrust faulted. West and northwest of the Little Dragoon Mountains, the Hidalgo thrust fault is offset northward by the Tungsten King and South Camp normal faults of Cooper and Silver (1964) and by the range front fault with which these normal faults probably merge. The thrust fault next extends across the southern part of the Johnny Lyon Hills, where it dips gently south to southwest, and farther west beneath the gravels of the San Pedro Valley. Across the valley the thrust fault is seen to emerge from the gravel cover in the southeast corner of the Rincon Mountains (Drewes, 1974), lying beneath a string of thin fault slivers of Paleozoic rock and Precambrian crystalline rock that apparently form a gently southeastward plunging asymmetrical synform.

From easternmost Arizona to the southeast corner of the Rincon Mountains, the Hidalgo thrust plate appears to thin, and on the south flank of the Rincon Mountains, the overlying Cochise thrust fault is believed to have cut out tectonically the entire Hidalgo plate and Hidalgo fault. However, younger gravity faulting in this area has greatly increased 
the structural complexity along the south flank of the mountains, and therefore the composite fault is called by its local name, the Santa Catalina complex fault. The Hidalgo thrust fault is not recognized at the surface elsewhere in the region, but it is inferred to project southward beneath the Hidalgo plate.

The Cochise thrust plate typically brings older rocks over younger ones and so is mainly an overthrust fault (Drewes, 1980). In the central part of the Dragoon Mountains, Gilluly (1956) recognized that upended and abundantly slivered Paleozoic and Precambrian rocks were thrust along the Dragoon fault upon Cretaceous rocks. The Cretaceous rocks are mostly gently dipping and little faulted; locally, they are folded but are not overturned (see section on southern Dragoon Mountains), as was once believed (Gilluly, 1956, pl. 6, sections X-XII). In the central part of the Dragoon Mountains, the thrust fault is cut by the Stronghold stock, of 22-23 m.y. age, near which an extra degree of structural complexity seems to reflect a forceful mode of intrusion. North of the stock the thrust fault reappears in a metamorphosed and intricately shingled thrust fault terrane (pl. 2), separating plates of lower Paleozoic and Precambrian rocks to the west from mixed plates of upper Paleozoic and Cretaceous rocks to the east. A short segment of the Cochise thrust fault occurs in the southeastern part of the Little Dragoon Mountains, where Cambrian rocks are faulted upon Pennsylvanian rocks (Drewes, 1980). Like the Hidalgo thrust fault beneath it, the Cochise thrust fault is intruded by the Texas Canyon stock, and farther west is concealed by the alluvium of the San Pedro Valley. Only the isolated knobs underlain by Rincon Valley Granodiorite southeast of the Rincon Mountains (Drewes, 1974) suggest a possible tie point for the Cochise thrust fault above the synform remnant of the Hidalgo thrust fault.

The trace of the Cochise thrust fault in the central part of the Dragoon Mountains extends southward around the east side of the Gleeson Quartz Monzonite of Jurassic age. The fault is seen to dip gently beneath the stock (this report, pl. 4; Gilluly, 1956; McRae, 1966; unpublished drill-hole data). A chaotic jumble of large structural blocks between Courtland and Gleeson is probably formed in part by a younger (only slightly younger?) volcano-tectonic event. South of the stock the thrust fault is concealed by alluvium. It is projected westward beneath the alluvium (Drewes, 1980) and is there offset by some younger movement on high-angle faults at the northern end of the Mule Mountains. This projection is appealing because of the structural similarity between the little-deformed Cretaceous rocks east of the central Dragoon Mountains and those of the northern Mule Mountains beneath the fault, and also because of the structural similarity between the thrust faulted Paleozoic rocks along the crest of the central Dragoon Mountains and those of the Tombstone Hills (this report, fig. 13; Gilluly, 1956, pl. 5). In this area the Cochise thrust fault is unexposed, but Gilluly mapped a thrust fault within the Paleozoic rocks that is probably a subordinate structure to that fault. The Cochise thrust fault thus is offset and concealed, and presumably continues southwestward beneath the surficial deposits of the San Pedro Valley.

The kind of faulting that is characteristic of the Cochise thrust fault occurs again along the crest of the Huachuca Mountains. There Paleozoic and Precambrian rocks are faulted along a northeastward dipping surface over Cretaceous rocks (Hayes and Raup, 1968). Accordingly, I propose (Drewes, 1980) that the Cochise thrust fault reappears from beneath the surficial deposits of the San Pedro Valley near the south end of the Huachuca Mountains and trends northward near the crest of the range to the north end, where it is offset westward by the Kino Spring fault.

The Cochise thrust fault, as described thus far, consistently separates a much-faulted older terrane above from a little-deformed younger terrane below. The Cretaceous rocks of the top of the underlying Hidalgo plate are folded in several places, whereas the Paleozoic rocks are cut by many younger-overolder bedding-plane faults that result in tectonically thinned stratigraphic sequences. This consistency seems to favor the proposed correlation, but westward from the Rincon Mountains and the Huachuca Mountains a somewhat different structural situation prevails.

In the north end of the Santa Rita Mountains is another belt of abundant thrust faults, which I propose closes the gap in the trace of the Cochise thrust fault. This western segment of the fault, referred to as thrust fault I by Drewes (1972a, pl. 4), brought Cretaceous and Paleozoic rocks along an eastward dipping shear surface onto Precambrian rocks, unlike the relations found to the east. Data from drill holes near Sonoita further suggest that the Cretaceous Bisbee Group underlies the entire basin. While at first glance this change in style-older-overyounger rocks to the east and younger-over-older rocks to the west-seems troublesome, it could make sense if the major plate is compared to some of the smaller structures in the region. These, too, vary from overthrust faults toward the east, to youngerover-older faults to the west. Like the little faults, the 
major ones may be shingled, with an easterly imbrication of the plates.

Thus far, the proposed correlation of segments of faults that comprise the Cochise thrust fault outlines a broad, saucer-shaped feature of inward-dipping shear surfaces. In the center of this part of the Cochise thrust plate lie the Whetstone Mountains, with their thick, little-faulted section of Precambrian, Paleozoic, and Mesozoic rocks (this report, fig. 11; Creasey, 1967). I suggest that the Cochise thrust fault extends beneath the Whetstone Mountains and that these rocks are less deformed than those near the Cochise thrust fault because this part of the plate was thickest.

In the Swisshelm Mountains, southeast of the Dragoon Mountains, is another belt of overthrusting, mapped by Epis (1956) and Cooper (1959) and reviewed, in part, during this study (pl. 5 and fig. 8). In places, Precambrian and lower Paleozoic rocks are thrust over Cretaceous rocks along an eastdipping fault. Elsewhere, Pennsylvanian rocks are thrust upon the Cretaceous beds. These relations suggest that the Cochise fault is present here, and the trace of this fault extends northward between low hills in which older rocks crop out to the east and younger rocks crop out to the west, as shown by Cooper (1959). The Cochise fault is also traced to the south (pl. 5), where it branches, swings eastward, and then is concealed by the mid-Tertiary volcanic rocks and gravel of Big Bend Creek and Mesa Draw. The fault reappears at Limestone Mountain in the northern Pedregosa Mountains (Drewes, 1980), where rocks of Paleozoic age are overthrust on Cretaceous rocks (Epis, 1956, and reconnaissance for this study). Because similar faulting is not recognized in the central Chiricahua Mountains (pl. 10), the eastern margin of the Cochise thrust plate is assumed to underlie the thick pile of young volcanic rocks of the southern Chiricahua Mountains, projecting thence northward and westward to the trace of the thrust fault in the low hills north of the Swisshelm Mountains. This part of the Cochise thrust plate, then, forms a smaller klippe east of the main part of the plate.

Exposed segments of thrust faults are scarce in that part of the southeastern lobe lying southwest of the Sawmill Canyon fault zone and the San Rafael Valley area near San Rafael de la Zanja Grant (Drewes, 1980). Small remnants of thrust faults do occur in the Santa Rita and Atascosa Mountains, and in a few places Cretaceous rocks display folding like that found near well-exposed thrust faults elsewhere in the lobe; hence, thrust faults probably are present but mainly concealed. In fact, in this southwestern area, rocks of post-thrust-fault age (upper part of the Salero Formation or younger) are more abundant than they are to the northeast. From photogeologic studies by Ludano Lucarelli (1967) of that part of Sonora near the southwestern area, it appears unlikely that additional control on thrust faults will be found, for the volcanic and plutonic rocks reported there are mostly of Tertiary age. Because of the scattered presence of signs of compressive deformation, and because of other signs of northeastward movement to be described in the section on "Direction and amount of tectonic transport of the allochthon." I suggest that the major thrust faults extend across the southwestern area in the subsurface.

In the northwestern allochthonous lobe, major thrust faults underlie two plates dominantly made up of Paleozoic rocks, and another underlies a plate or plates of Precambrian and Mesozoic rocks. The names given to the major thrust of the southeastern lobe are not applied in the northwestern lobe because either the history of movement or the rate of movement of the two lobes differed, as implied by the tear fault (Sierrita line) between the lobes. However, similar horizons of structural weakness may have been followed by the faults, so that superficially they may look alike. A lower sheet of Paleozoic rocks overlies the San Pedro thrust fault and makes up the San Pedro thrust plate, and an upper one overlies the Santa Cruz thrust fault and forms the Santa Cruz plate. An intervening thrust plate is underlain by the Rincon Valley Granodiorite fault where the Rincon Valley is the dominant rock of the medial plate, and the fault is unnamed elsewhere until further evidence of its identity is available.

The San Pedro thrust fault forms a southeast- to northeast-dipping shear surface around the east flank of the Rincon Mountains (Drewes, 1974). Along the west flank of the northern part of the Johnny Lyon Hills, it underlies the westernmost outcrops of Paleozoic rocks but is concealed beneath the pediment gravel. There it is presumed to dip eastward subparallel to better exposed thrust faults associated with the locally underthrust wedge of the lead edge of the northwestern lobe. Northwest of Happy Valley and near the Happy Valley normal fault, the San Pedro thrust fault and plate are truncated by overlying thrust faults. Also in this area, a minor branch of the San Pedro thrust fault follows a slightly lower structural horizon, beneath a sheet of quartzite-rich Pinal Schist. Typically, the thrust faults follow major zones of weakness at the base of the Paleozoic sequence or at the base of the Apache Group. Locally, sheets of schist in the 
basement rocks also guided fault development. Such sheets of the Pinal Schist cap two of the knobs on the crest of the Rincon Mountains (Drewes, 1977), suggesting that possibly the main thrust fault lay only a short distance higher before being eroded.

On the west side of the Rincon Mountains and south of the Tanque Verde Mountains (also known on some maps as Tanque Verde Ridge of the Rincon Mountains), the San Pedro fault is probably part of the south- and west-dipping Santa Catalina complex fault, along which slivers of metamorphosed Paleozoic rock lie between the autochthonous crystalline core of the mountains and the plate of Rincon Valley Granodiorite. Subsequent movement on this segment of the San Pedro fault has complicated the field relations. Around the Rincon Mountains the outward dip of the San Pedro fault reflects the later uplift and doming of the core rocks.

On the west side of the Sierrita Mountains, the San Pedro thrust fault is believed to underlie the more western of two belts of steeply northeast-dipping metamorphosed Paleozoic rocks (Drewes and Cooper, 1973). On the east side of the mountains, near Twin Buttes, a gently southwest-dipping fault that may be another segment of the San Pedro thrust fault (Drewes, 1980) separates metamorphosed Paleozoic rocks from possibly autochthonous crystalline rocks (Cooper, 1973). This correlation of thrust faults across the Sierrita Mountains is proposed because on each side of the mountains there is a structurally higher subparallel fault that involves a second sheet (Santa Cruz plate?) of Paleozoic and Mesozoic rocks. In the Twin Buttes area, about $5 \mathrm{~km}$ west of Green Valley, the proposed segment of the San Pedro fault is traced eastward to the edge of the gravel deposits of the Santa Cruz Valley and westward to the Ruby Star stock, which intruded the fault in Paleocene time. Apparently the fault originally trended northeastward along the zone now occupied by the stock, for it is not recognized anywhere to the west of the stock. Support for this interpretation comes from the distribution of the overlying segments of the Santa Cruz thrust fault.

The Santa Cruz thrust fault is nearly coextensive with the San Pedro thrust fault, and in many places lies close above it, for the San Pedro plate is thin. On the east side of the Rincon Mountains, the Santa Cruz thrust fault brings unmetamorphosed Paleozoic and upper Precambrian bedded rocks mostly upon the Rincon Valley Granodiorite but locally upon the metamorphosed Paleozoic rocks of the San Pedro plate or even upon gneissic rocks of the autochthon. Particularly significant is the presence of the same formations in both plates of Paleozoic rocks; this relation requires overthrusting rather than younger-over-older thrusting, and the extent of the duplication of formations in the direction of transport gives a minimum distance of transport. East of the Rincon Mountains and the San Pedro River, the Santa Cruz thrust fault probably underlies the thin upper and eastern belt of Paleozoic rocks that lie between the Walnut Gap Formation to the west and Johnny Lyon Granodiorite to the east (Cooper and Silver, 1964; Drewes, 1980). The combined thickness of the two plates of Paleozoic rocks and the intervening sheet of the Walnut Gap of Triassic or Jurassic age is probably only a few hundred meters, in accord with the interpretation that this underthrust sheet wedges out eastward.

On the west side of the Rincon Mountains, the Santa Cruz thrust fault may have been responsible for emplacing some unmetamorphosed Paleozoic rock upon the gneissic rocks of the core of the mountains (Drewes, 1977). The amount of movement on this fault attributable to gravity sliding is far too little to produce the great amount of tectonic thinning of the Paleozoic sequence. Near the Madrona Ranger Station at the head of Rincon Valley, for example, trilobite-bearing Abrigo Formation of Cambrian age rests upon marmorized Horquilla Limestone of Pennsylvanian age, and nearby a wedge of Rincon Valley Granodiorite is faulted between the Abrigo and the Horquilla (Drewes, 1971d and 1977).

About midway between the Rincon and Sierrita Mountains, a deep exploratory well provides some evidence pertaining to the proposed correlation of thrust faults across the Tucson basin. This well, the Humble No. 1 State, reached a depth of $3,727 \mathrm{~m}$, bottoming in a granitoid rock that I judge to be of Precambrian age, although it may have been recrystallized during the Tertiary. This age assignment is based on a comparison of rock types, an available K-Ar age of 46 m.y., a Rb-Sr age of 120 m.y. obtained from well cuttings, and the fact that granitic rocks of 120- to 650-m.y. age are unknown in southeastern Arizona. Similarly diverse ages have been obtained from rocks in the Rincon and Santa Catalina Mountains (24-160 m.y.), which, in turn, are lithologically correlated with known Precambrian Continental. Granodiorite and other units. The disparity between the ages obtained using different radiometric methods could indicate that both ages were probably made younger through some postcrystallization process. Furthermore, inasmuch as granitic rocks of $120-$ to $650-\mathrm{m}$.y. age are relatively scarce, a Precambrian granitoid rock is the 
most likely one encountered at the bottom of the hole. About $70 \mathrm{~m}$ from the bottom of the hole, a thick gouge zone was penetrated. Cuttings from above the gouge zone show a thin sequence of rock which I interpret to be, in rising order, Rincon Valley Granodiorite, Pioneer Formation, metadiabase and, finally, a thick pile of Tertiary gravel and silt. The sequence between the gravel and the gouge zone resembles that found at Pistol Hill, Sentinel Butte, and other places around Rincon Valley. Thus, it seems probable that the structures at the foot of the Rincon Mountains extend well beneath the gravel deposits of the Tucson basin. And furthermore, subsequent gravity movement has not piled up glide plate material in this part of the basin, thus supporting the idea that gravity tectonics involved only small amounts of movement. The gouge zone is probably the combined San Pedro and Santa Cruz thrust fault.

Again on the west side of the Sierrita Mountains, the Santa Cruz thrust fault is believed to form an east-dipping fault beneath the eastern of two belts of metamorphosed Paleozoic rocks (Drewes and Cooper, 1973). The fault is also believed to occur along a line slightly oblique to the crest of the mountains. To the north and on the west side of the crest, west-dipping slivers of Paleozoic limestone are faulted into the Jurassic (Marvin and others, 1973) Sierrita Granite of Lacy (1959). To the south and on the east side of the crest, Cooper (1973) showed a west-dipping thrust fault cutting volcanic and plutonic rocks of Jurassic or Triassic age. Between these places, inclusion of Paleozoic rock in a second mass of Ruby Star Granodiorite may mark the intruded trace of the fault, and elsewhere the fault probably was not recognized because of the massive rock types and poor exposures.

The evidence for thrust faulting in the Tucson Mountains is too fragmentary to provide means for identifying specific major faults there, but the rocks of pre-Cat Mountain Rhyolite age have beddingplane faults and folds much like those in the other older rocks of the region.

STYLE OF DEFORMATION OF THRUST PLATES AND FAULTS

The tectonic style of deformation of the thrustfaulted rocks is fairly uniform throughout the region, implying that the conditions under which thrusting occurred did not vary much from place to place, a situation compatible with a hypothesis of regional thrust faulting. Typically, the major thrust faults were subhorizontal surfaces, probably more or less parallel to the position of bedding at the time of thrusting. Some large undulations may have occurred on the major faults to produce the basinlike configuration of the faults envisioned to underlie the Whetstone Mountains. Other undulations on the major faults may have produced the local truncation of underlying thrust plates by overlying ones. Possibly the synform in the thrust fault at the southeast corner of the Rincon Mountains is due to tectonic gouging, for subsequent folding is not recorded by a synclinal structure in the foliation of subjacent rocks.

The medial rocks of the thrust plates are less deformed than are the rocks immediately adjacent to the major thrust faults. Bedding-plane faults, normal faults, and disharmonic folds are the most common structural features, and tear faults and drag folds also occur. The bedding-plane faults mostly bring younger rocks over older ones, with the result that some of the intervening units are faulted out. Usually, bedding-plane faults follow rock units that have little structural strength, such as shale, marl, and schist; the interface between massive and bedded rocks is also a common slip surface. In the Swisshelm, southern Dragoon, and northern Chiricahua Mountains and other places, minor beddingplane faults branch from major thrust faults. And in a few places, such as the northern Dragoon Mountains, bedding-plane faults are minor overthrust structures that separate shingled thrust plates from each other. But everywhere the minor faults occur, they are subparallel to the major thrust faults and merge with them or with each other from place to place to produce a set of rather undeformed thrust platelets. Isoclinally folded thrust faults have been reported by Gilluly (1956) in the northern Dragoon Mountains and by Sabins (1957a) in the northern Chiricahua Mountains, but further studies, described in the sections of this report on those areas, show that alternative interpretations of the structures are favored in both cases.

Normal faults disrupt the beds of some minor thrust plates without offsetting the plate boundary. They seem to trend randomly and are small features in both length and amount of offset. Typically, they are marked by the offset of a resistant marker bed within a structurally weak formation, which has unbroken contacts but may be thinned or disharmonically folded. These normal faults are thus also disharmonic structures and were formed as adjustments to local stress variations within minor thrust plates.

Tear faults typically trend east-northeast and dip steeply or are vertical. In some places, direct evidence of horizontal or subhorizontal movement occur; elsewhere such movement is implied by 
infaulted slivers of rocks that are absent in the adjacent blocks, or by the juxtaposition of diverse structural features. Many tear faults are small features, resembling in many respects the disharmonic normal faults, but a few tear faults, such as the Sierrita line, are very large and complex features.

The Sierrita line is in part a tear fault that separates the two allochthonous lobes. A variety of structural relations occurs along the Sierrita line; these are illustrated in sequence from northeast to southwest in figure 6 . An underthrust wedge is inferred east of the San Pedro River and mainly west of the Johnny Lyon Hills (fig. 6A). West of the San Pedro River, near the section of figure $6 B$, the Sierrita line is actually an unmodified tear fault between allochthonous upper Paleozoic rocks to the northwest and autochthonous Precambrian rocks to the southeast. The presence of a sliver of Cambrian Bolsa Quartzite and of subhorizontal slickensides in Red Rock Canyon (Drewes, 1974) are evidence of lateral movement. A few kilometers southwest, near Happy Valley, the tear fault is exposed at a slightly deeper structural level, and is seen to flatten and merge with the San Pedro thrust fault. The Sierrita line is absent over the Rincon Mountains (fig. 6C), having been eroded away. Near Colossal Cave on the southwest flank of the Rincons (fig. 6D), the Sierrita line is again seen as a tear fault, but there it separates a thick plate of Rincon Valley Granodiorite to the northwest from a very thin plate of the granodiorite overlain by a thick and much faulted part of the Cochise thrust plate to the southeast. The underlying gneissic autochthon is unbroken by the tear fault: A branch of the tear fault flattens southeastward, to merge with the thrust fault separating a thin plate of granodiorite from the overlying bedded rocks of late Precambrian and Paleozoic ages. Several small slivers of Bolsa Quartzite, Pioneer Shale, and Bisbee Formation that lie along the fault do not occur in the adjacent parts of the main blocks, a relation common along tear faults.

The Sierrita line is projected farther southwest beneath the alluvium of the southern part of the Tucson basin to the southeast side of the Sierrita Mountains. Near the edge of the gravel cover and east of the Esperanza Mine (fig. $6 E$ ), the fault is intruded by the Ruby Star stock, of Paleocene age. Near the Esperanza Mine a steep, southwesttrending normal(?) fault separates Triassic volcanic and plutonic rocks of the northwestern lobe from Upper Cretaceous dacitic volcanic and sedimentary rocks to the southeast (Cooper, 1973). West of the mine (fig. $6 F$ ), the fault is covered first by mid-
Tertiary conglomerate and than by rhyolitic volcanic rocks that are only slightly younger than the dacitic rocks. On the southwestern side of the Sierrita Mountains (fig. 6G), the fault emerges from beneath the rhyolitic cover and is seen to separate thrust-faulted Paleozoic metamorphic rocks and Jurassic quartz monzonite of the northwestern lobe from the dacitic volcanic rocks of the southeastern lobe. The southernmost outcrop of the southeasttrending belt of Paleozoic rocks has been dragged northeasterly into the trace of the northeasttrending fault, indicating that the fault has had a left-lateral tear component of movement. Even the inferred normal movement near the Esperanza Mine is only a measure of normal offset, and a tear component of movement is not excluded. In summary, the Sierrita line is believed to be, at least initially, a left-lateral tear fault genetically related to the Cordilleran regional thrust faults. The tear fault was subsequently concealed, intruded, or eroded, and in places it may have been modified by other and more local fault movement.

Smaller tear faults are also demonstrably related to thrust faults. In the northern Dragoon Mountains (pl. 2), the Fourr Canyon thrust fault, one of the larger of the "minor" thrust faults within the Cretaceous rocks of a siltstone-rich facies from upended metamorphosed Paleozoic rocks and Cretaceous rocks of a conglomerate-rich facies. Along the northwest side of the Fourr Canyon plate in Fourr Canyon, the fault steepens to a nearly vertical, northeast-striking surface, which is a tear fault because the lower plate rocks are not offset by this structure. In the northern Whetstone Mountains (fig. 11) another tear fault adjacent mainly to Cambrian formations is seen to merge downdip with a minor thrust fault underlying the same formations.

Other faults with a probable strike-slip component of movement occur in clusters in rocks near the major thrust faults. Examples of such faults occur north of Portal in the central Chiricahua Mountains (pl. 10), the northern Huachuca Mountains (pl. 6; Hayes and Raup, 1968), and the northern Santa Rita Mountains (Drewes, 1971a and 1972a, pl. 4). Their genetic association with the thrust faults is not only indicated by their spatial association, but also by the disharmonic relations of some of them to the features across the nearby thrust faults.

Folds are widely scattered throughout the region, and many clusters of folds lie close to segments of thrust faults. The folds are of many sizes. Only the larger ones, having amplitudes of at least a few hundred meters, are shown on the regional map 
A. EAST OF SAN PEDRO RIVER

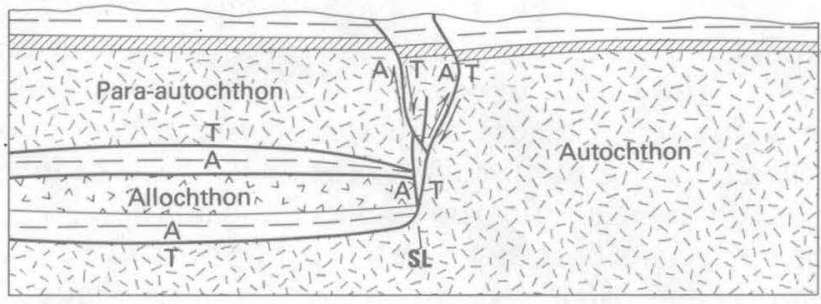

B. WEST OF SAN PEDRO RIVER

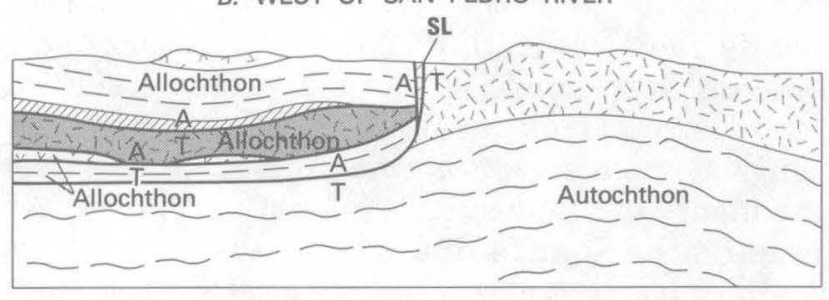

C. RINCON MOUNTAINS
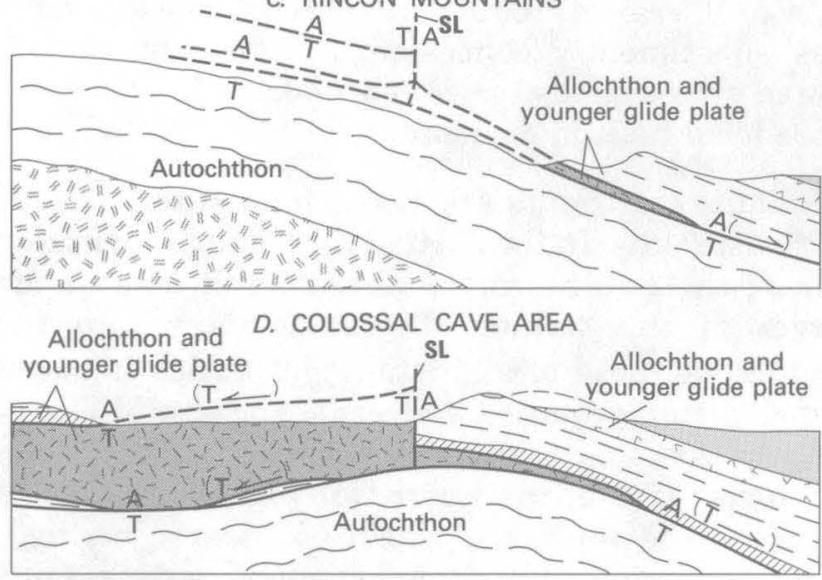

E. SOUTHEASTERN SIERRITA MOUNTAINS

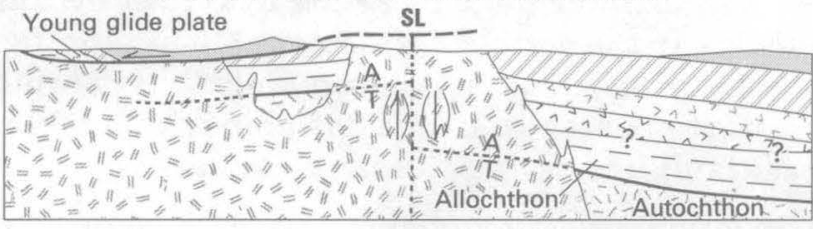

F. SOUTH-CENTRAL SIERRITA MOUNTAINS

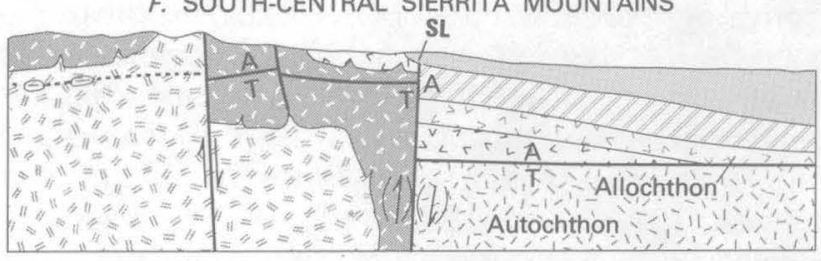

G. SOUTHWESTERN SIERRITA MOUNTAINS

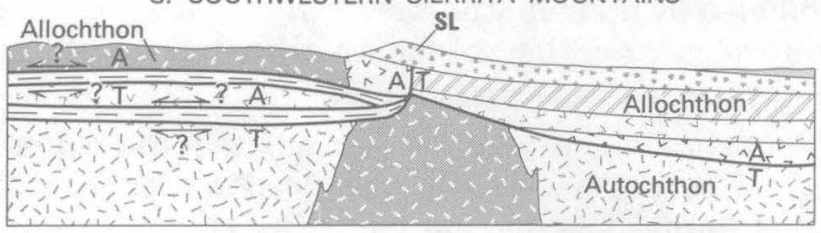

\section{DESCRIPTION OF UNITS}

SEDIMENTARY AND VOLCANIC ROCKS (TERTIARY)

PLUTONIC ROCKS (TERTIARY)

RHYOLITIC WELDED TUFF (UPPER CRETACEOUS)

DACITIC VOLCANIC ROCKS AND SEDIMENTARY ROCKS (UPPER CRETACEOUS)

SEDIMENTARY ROCKS (LOWER CRETACEOUS)

PLUTONIC ROCKS (JURASSIC AND TRIASSIC)

SEDIMENTARY AND VOLCANIC ROCKS (JURASSIC AND TRIASSIC)

SEDIMENTARY ROCKS (PALEOZOIC)

SEDIMENTARY AND IGNEOUS ROCKS (PRECAMBRIAN, ABOUT 1200 M.Y.)

RINCON VALLEY GRANODIORITE (PRECAMBRIAN, ABOUT 1650 M.Y.)

PLUTONIC ROCKS (PRECAMBRIAN, ABOUT 1650 M.Y.)-Excluding Rincon Valley Granodiorite

METAPLUTONIC AND METASEDIMENTARY ROCKS (PRECAMBRIAN, ABOUT 1715 M.Y.)

CONTACT-Dashed where projected above surface

FAULT-Dotted where intruded; dashed where projected

Movement directions:

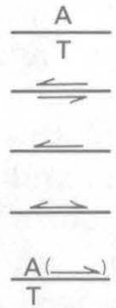

$A$, away from viewer; $T$, toward viewer

Arrow couple shows relative movement

Arrow-half shows direction of movement of glide plate or hanging wall of low-angle normal fault

Double-headed arrow shows directions of movement

Parenthetic symbol shows the younger of two times of movement

FIGURE 6.-Diagrammatic structure sections of structural relations along the Sierrita line, SL, between the area east of San Pedro River and the southwestern flank of the Sierrita Mountains. 
(Drewes, 1980); the smaller ones either are shown individually on the local maps in the "New field studies" section of this report or are shown on some of the previously published maps (fig. 1). Most of the folds are systematically oriented, with northnorthwest-trending and gently but randomly plunging axes. Axial planes are mostly upright or steeply dipping. Fold limbs are open to moderately tight, and in places the fold crests are fairly sharp, approaching the aspect of chevron folds. In several places the larger folds are disharmonic structures. On a smaller scale, disharmonic folds also are found in weak rocks adjacent to bedding-plane faults separating the less competent units from the more competent ones.

A few folds are exceptions to the kinds described above, and they are believed to have formed at other times in response to different stresses. They include the steeply plunging folds in Precambrian quartzite of the northern Chiricahua Mountains (pl. 3) and some of the flat-lying folds apparently draped more or less radially around some flanks of the Rincon Mountains (Davis, 1975), and they are of concern mainly in local studies. A few other major folds that are reported in the literature of the Dragoon, Swisshelm, and Chiricahua Mountains have been reinterpreted in this study as other kinds of structures, and are discussed in sections on these mountains. And finally, a few folds that trend northeast are associated with local thrust faulting and tear faulting of late Cordilleran (Helvetian) age (Drewes, 1972a).

Drag folds occur in places close to thrust faults and other kinds of faults. They are usually small features and in many cases are the basis for interpreting the movement direction shown on maps of the region. Consequently, they need no further attention here, with the exception of one group of folds. East of the Rincon Mountains, chiefly between Hells Gate and the edge of the San Pedro Valley (Drewes, 1974), the rocks of the lower plate are strongly sheared and in places have many flow folds with tight limbs and amplitudes of a few meters to a few tens of meters. Like the other folds, these are disharmonic features with respect to the subjacent rocks; in other words, they affect rocks only on one side of the fault. Unlike the other folds, however, their axial planes are strongly inclined and even subhorizontal. The more intense deformation of these rocks that is implied by the tighter folds, greater inclination of fold axes, and flowage of some beds in the folds may be evidence of a locally greater confining pressure than usually occurs near thrust faults of the region. This situation is compatible with the proposed local underthrust wedge of a nearby part of the northwestern allochthon.

\section{DIRECTION AND AMOUNT OF TECTONIC TRANSPORT} OF THE ALLOCHTHON

On the aggregate, the available evidence from regional geologic relations and from the small structural features indicates that the allochthon moved east-northeastward at least $18 \mathrm{~km}$. The total amount of transport may be on the order of $200 \mathrm{~km}$.

Three aspects of direction of tectonic transport are considered independently and in the following order: (1) orientation of movement, (2) relative direction of movement, and (3) actual movement of the two masses under consideration (that is, which block was active and which passive).

Orientation of movement, either east-northeast ward or west-southwestward, is reliably determined from the fairly consistent orientation of tear faults and folds, which were formed in response to the same stresses that formed the thrust faults. The northnorthwest-trending axes of folds described in the preceding section indicate that the maximum compressive stress was oriented at right angles-east northeast, west southwest; for simplicity, this direction is given henceforth as northeast-southwest. The orientation of the tear faults, and especially of the larger ones, also indicates that the plates broke apart and moved northeast or southwest with respect to each other or to part of the autochthon. The few folds and tear faults with greatly different orientations are accounted for by known tectonic events of other kinds or other times, principally by strike-slip faulting and associated local folding of Precambrian or Paleocene ages and by mid-Tertiary gravity movement off local topographic high areas.

The relative movement direction of the allochthon is believed to have been northeastward, but evidence favoring this direction over the opposite one is mixed. Vergence of folds, direction of imbrication of minor thrust plates, and the offset of specific features provide some insight into the relative movement of the major plates with respect to other major plates or to the underlying rocks. A few points based on geology outside of the region lend additional support for inferring that the upper structural units generally moved northeastward relative to the lower ones.

The vergence of folds-in essence, the direction of inclination of axial planes of folds with respect to genetically related thrust faults-is more commonly northeast than southwest. For example, in the Santa Rita Mountains, northwest-trending folds occur in four areas (Drewes, 1972a). In three areas-Helvetia to the north, Greaterville in the center, and Montosa Canyon to the west-the fold axes are vertical to steeply southwest dipping. An association with 
thrust faults that dip southwest or are horizontal is demonstrable, so that vergence is inferred to be northeast. The axial planes of folds at Adobe Canyon in the southeast part of the mountains, however, dip to the northeast and abut a moderately east-dipping fault. This relation could be taken as evidence of a southwest vergence, but I suggest that the evidence is equivocal because the local geologic history and other structural relations indicate that there were two phases of movement on the fault, the youngest possibly being a reverse fault movement in response to lateral stress produced by the implacement of stocks of post-thrust age in the core of the mountains.

The folds on the southwest side of the Huachuca Mountains also present a picture that is difficult to interpret. The axial planes of folds dip about as commonly to the southwest as to the northeast, and two folds were shown by Hayes and Raup (1968) to be overturned to the southwest. My studies in the northern end of the range (pl. 6 and section on "Northern Huachuca Mountains") show that one of these overturned folds may not exist. I did not examine the other of these folds, along the crest of the range, but it deserves careful review, because it was identified in the field on the basis of crossbedding in the Bisbee Group, a criterion that has resulted in past misinterpretations not only in the southern part of the Dragoon Mountains (pl. 4 and section on "Southern Dragoon Mountains"), but also in the northern part of the Huachuca Mountains themselves (pl. 6).

The faults that may be genetically related to this group of folds are difficult to identify. I feel that the folds are most likely related to the Hamburg fault of Hayes and Raup (1968), to similar but unnamed faults near Wakefield Camp, and to those west of the main mass of the Huachuca Quartz Monzonite. They probably are not related to the thrust fault that Hayes and Raup map northeast of the folded Bisbee Group. The reason for this preference is that the thrust fault is shown to cut segments of a very long fold, whereas the axial planes of other folds merge along strike with the Hamburg and similar faults. Probably these broken-crested folds are the ends of shingled minor thrust plates that are nearly vertical at their level of exposure but that flatten out at depth, where they merge with a major thrust fault. The thrust fault to the northeast of the folds, then, truncated or hindered the further development of imbrication, so it need have no genetic association with the folds. Thus, the association of the folds with vertical segments of generally southwest-dipping local thrust faults would give the folds a northeast vergence.
Where minor thrust plates appear to be imbricated, they dip southwest, thereby also suggesting that the upper plates moved northeastward relative to the lower plates. Such imbricate platelets, or shingled minor thrust plates, at the southwest side of the Huachuca Mountains were described in the preceding paragraph. Other platelets of this kind have been mapped in the northern part of the Dragoon Mountains (pl. 2), and still others are inferred in the central part of those mountains from Gilluly's (1956, pl. 5) map. In the Wood Mountain area of the northern Chiricahua Mountains, Sabins (1957a) also showed repeated sequences of Paleozoic and Cretaceous formations on what are probably several minor thrust faults. In all cases the platelets and their intervening thrust faults dip south to west, so the upper plates probably moved northeastward relative to the lower plates.

Regional considerations of possible source areas of the allochthon also favor a northeastward movement rather than a southwestward one. In a general sense, the terrane to the northeast of the region is less complex than that to the southwest. Thus, the orogenic center during Cordilleran time probably lay to the southwest. A review of the distribution of geologic features that should be found near a source area of these plates under two tectonic models-one involving regional gravity sliding and the other involving thrusting from an orogenic core area-will illustrate my point.

First, let us consider the region to the northeast of the study area. Plate genesis involving gravity movement on a regional scale down even so gentle a slope as $1^{\circ}$ should leave behind an uplifted and deeply eroded source area. But no such area has been identified; zones of Paleozoic and Mesozoic rock occur among the Precambrian areas all along southcentral New Mexico and eastern Arizona. Under the alternative hypothesis of plate genesis by forceful thrusting, the source area should be marked by a belt of intense deformation and (or) plutonic invasion of Cordilleran age. Again, such a belt is not found, although some faults and stocks do occur. The host rocks of these stocks are mostly little deformed and only locally contact metamorphosed, unlike the rocks that ought to be found where thrust plates originate. Clearly the area to the northeast is an unlikely source of the thrust plates.

The terrain to the southwest is topographically lower, and alluvial deposits are more extensive near the Gulf of California. Such rocks of Cordilleran orogeny or pre-Cordilleran age that do crop out are chiefly granitoid stocks and batholiths. A few of these have been dated as Precambrian and more as Late Cretaceous, but many still are undated. The 
sparse remnants of wall rocks of these stocks are pervasively metamorphosed. While our knowledge of the geology of southwestern Arizona and northwestern Sonora is still in an embryonic stage and provides scant basis for any tectonic hypothesis, the terrain was more likely an orogenic source area of regional thrust plates than was south-central New Mexico. Plate movement thus was more likely northeast than southwest.

A final but tentative argument in favor of northeastward moving thrust plates is an outgrowth of a postulated and incompletely documented case of offset of a stock that predates the movement on a major thrust fault. This case is described below, in the section on amount of tectonic transport. If furthur investigation substantiates the postulated offset, then the movement direction for a major part of the Cochise thrust plate is about N. $70^{\circ} \mathrm{E}$.

The tectonic synthesis of southeastern Arizona has provided no evidence to indicate which rock mass was the active one and which the passive one. This result is not surprising, because for any local area within a region to which a stress is applied, the patterns of deformation in active and passive rocks are identical. Differences in deformation from place to place reflect the anisotropic properties of rocks, variations in confining pressure, and perhaps duration of stress application, but not the direction of the maximum stress. Large as the study area is, the structures are seen to extend beyond it. Under this circumstance, of course, the strict application of the terms "allochthon" and "autochthon" to the active and passive plates, respectively, is not possible. However, as these terms are commonly applied to mean "upper plate" or "lower plate," or perhaps even "more deformed rock mass" versus "less deformed rock mass," the terms remain useful, and are retained in this report.

The same situation occurs elsewhere in the Cordilleran orogenic belt, and perhaps in many other orogenic belts as well. Local or semiregional studies typically do not support the determination of active or passive plates. Such assignments are made in cases of gravity sliding, for there the full extent of a stress field-the glide plate and subjacent rocks-is known or at least assumed. Where such assignments are made in cases of other tectonic geneses, they must be based on another type of broadly regional synthesis. In the final section of this report, "Regional implications of the tectonic synthesis," there will be a need to return to some inferences of continental scope, and so I will defer further consideration until then. Suffice it here to state that I believe both masses to have been active plates converging upon each other, in all likelihood propelled from midoceanic spreading centers on distant margins of global plates.

A minimum distance of tectonic transport is given by the overlap of several formations that are repeated in adjacent thrust plates. The rocks of the Rincon Mountains provide a unique measure of minimum distance of tectonic transport between two major thrust plates, the San Pedro and Santa Cruz thrust plates, as has been explained in the above section on geometry of the thrust faults. The overlap distance across which the same formations appear in the two plates in the direction of transport (as obtained from independent evidence) is the minimum distance of tectonic transport. Where the continuity of the thrust plates is relatively good, on the east side of the Rincon Mountains (Drewes, 1974), that distance of plate duplication is about $16 \mathrm{~km}$. Considering the larger area where the remnants of the thrust plates are more widely spaced, which extends from east of the San Pedro River to the west side of the Rincon Mountains (Drewes, 1974 and 1977), the distance of plate duplication is at least twice as large, or $32 \mathrm{~km}$ (Drewes, 1973). Add to either of these distances an estimated commensurate amount of movement between the San Pedro thrust plate and underlying autochthon, and a truly large distance of tectonic transport is called for.

An actual distance of tectonic transport on the Cochise thrust fault possibly may be inferred from a pre-Cordilleran orogeny stock that appears to be decapitated. Where thrust faults that mainly follow bedding planes encounter geologic features lying transverse to the bedding, such as a stock, the stocks must be sheared and offset like a rivet that is not strong enough to prevent the separation of two metal plates under shearing stress. The few stocks of Jurassic age may act like geologic "rivets," for they intruded both basement rocks and overlying bedded rocks. The challenge is to find two masses of granitoid rock in different major thrust plates that can be correlated.

In southeastern Arizona there are six known Jurassic granite masses, five of them in the southeastern lobe. Of these five, only the Gleeson stock in the Dragoon Mountains is known both to be in the Cochise thrust plate and to be underlain by a thrust fault (see sections, "Geometry of the thrust faults" and "Southern Dragoon Mountains"). The other four masses-Juniper Flat stock in the Mule Mountains, Huachuca stock in the Huachuca Mountains, Amado stock in the northern Tumacacori Mountains, and Squaw Gulch-Patagonia stock in the southern Santa Rita and northern Patagonia Mountains-are believed to be in the Hidalgo thrust plate. There may be others not presently exposed and not recognized 
by geophysical signatures presently available; this possibility, however remote, will always impair an attempt to show that a given correlation of stocks is unique.

Before making even a tentative correlation, some precautionary points should be considered. How uniform must the "rivet" be to suggest a correlation? Or how much do we know of the kinds of changes and rates of changes of composition occurring in stocks that may have to be accommodated in a correlation attempt? And how much of the "rivet" may be missing through a combination of tectonic action and erosion since thrust faulting? Geologic studies of stocks and batholiths commonly treat the variations of texture, mineralogy, and chemistry at a fixed depth of exposure; less is known about systematic vertical variations. Any attempt to deal further with these variations may be influenced by the local field situations, considered next.

Of the four options in correlation that are possible, I provisionally suggest that general geologic relations best support the inference that the Squaw Gulch-Patagonia stock in the Santa Rita and Patagonia Mountains, of the Hidalgo plate level, is the decapitated lower part of the Gleeson stock. The following field relations support this correlation in a general way. First, the direction of movement of the Cochise plate that could produce the inferred offset of the top of the stock is parallel to that of the larger tear faults related to the plates. Second, the amount of movement required by this correlation does exceed the several tens of kilometers of transport required by the evidence of duplicate formations. Third, the Squaw Gulch-Patagonia stock is larger than the Gleeson stock, which seems appropriate if it represents the deeper level of the original stock within a few kilometers of the surface; by contrast, the other candidate stocks have a much smaller girth. Fourth, the Squaw Gulch-Patagonia stock has no remnant of roof rocks to mark its upward termination, whereas the other stocks do have some capping host rock. Fifth, Precambrian granitoid rocks and schistose or gneissic host rocks are present west of the north ends of both the Squaw Gulch and Gleeson stocks. Sixth, very coarse grained, darkgray, plagioclase-rich monzonite lies east of the north ends of these stocks and occurs in only one other place in southeastern Arizona. A Late Triassic radiogenic age is obtained from both the Piper Gulch Monzonite of the Santa Rita Mountains and the Harris Ranch Monzonite (Damon and others, 1965) of the Sierrita Mountains; dating the Copper Belle Monzonite Porphyry of the Dragoon Mountains, which would be most useful, has not yet been successful because of the intense alteration of that rock. Seventh, a strongly developed and probably complex (i.e., reactivated) northwest-trending steep fault lies on the northwest side of both stocks. In the Santa Rita Mountains this fault is known as the Salero fault zone and is inferred to have been active in pre-thrust fault (pre-Salero Formation) time (Drewes, 1972a). In the Dragoon Mountains it is unnamed and appears as a pair of faults that cut the Cochise thrust fault and change its trend so abruptly and enigmatically at South Pass (this report, pl. 4; Gilluly, 1956) that pre-thrust faulting is herein proposed.

Accepting for the moment the merits of the above arguments used to favor a correlation between the Squaw Gulch-Patagonia stock and the Gleeson stock, let us consider further the questions raised but left unanswered in the second preceding paragraph. If the Squaw Gulch-Patagonia stock is indeed tectonically decapitated, then how much of the stock might have been removed through the faulting and especially through subsequent erosion? It has been inferred that the Santa Rita Mountains were uplifted and deeply eroded during latest Cretaceous and Cenozoic time. Parts of three formations, the Salero Formation and the Gringo Gulch and Grosvenor Hills Volcanics, lapped up onto the stock but were removed by progressively deeper erosion of part of the stock. Because of onlapping basal relations of each of these formations, I can only estimate that a layer of stock $1,000-2,000 \mathrm{~m}$ thick was removed. Under these circumstances, only a general fit of geologic features seems required to suggest correlation of the stocks. Further efforts to test the possibility of this correlation on the bases of petrographic characteristics must also take into account this gap in the continuity of remnants of the stock.

The rocks of the Squaw Gulch-Patagonia stock and the Gleeson stock have some features in common as well as others that are dissimilar. Other Jurassic stocks are inadequately studied for any petrographic comparison; in fact, even the Squaw Gulch-Patagonia body is very incompletely known because so much of the central and western part of it is covered by younger rocks and because petrographic study in the Patagonia Mountains was cursory. Rocks of both stocks are typically friable and weather to form subdued outcrops; those of the Gleeson stock are so friable, in fact, that specimens for thin sectioning are difficult to obtain. Perhaps this condition itself reflects the tectonic history of the mass. Rocks of both stocks also have a moderate to coarse grain size and a hypidiomorphic granular texture, and they 
have the same suite of major minerals (quartz, albite or oligoclase, microcline, and biotite) and minor minerals (magnetite, apatite, and zircon and locally also some sphene, amphibole, and allanite). From modal analyses of about 20 specimens of each stock, the Squaw Gulch body is found to be granite to the southeast and quartz monzonite to the northwest (Drewes, 1976d), whereas the Gleeson body is quartz monzonite to the north and south and granodiorite in the middle. While this difference in mode does not support a direct correlation between separated parts of a compositionally uniform stock, it is not so different as to eliminate correlation of separated parts of a compositionally zoned stock. For instance, the Gleeson rocks could have come from a structurally higher and more centrally situated part of a stock, and the Squaw Gulch specimens may represent a marginal and possibly deeper level of the same body. So the petrographic evidence remains inconclusive; the Gleeson stock could be, but need not be, part of the Squaw Gulch-Patagonia stock.

The weight of evidence favoring the correlation remains with the general field relations. If the evidence is accepted, then the Gleeson mass moved about $100 \mathrm{~km} \mathrm{~N} .70^{\circ} \mathrm{E}$. from the Squaw GulchPatagonia mass. Again, if a similar magnitude of movement is assigned to the Hidalgo thrust fault as is here argued for the Cochise thrust fault, then tectonic transport is on the order of $200 \mathrm{~km}$. This distance is remarkably similar to those proposed, on different kinds of evidence, along the Cordilleran thrust belt in Alberta $(200 \mathrm{~km}$ or more, Price and Mountjoy, 1970), Utah (160 km or more, Stewart and Poole, 1974; or $85 \mathrm{~km}$, Rubey and Hubbert, 1959; Crittenden, 1961), and southern Nevada (36-75 km or more, Burchfiel and others, 1974; or 30-50 km, Fleck, 1970; or about $120 \mathrm{~km}$, Steward and Poole, 1974). Attractive as these comparisons are, my support for such a large distance of tectonic transport is based on imperfect evidence and on projections of movement from the Cochise to the Hidalgo thrust fault. Therefore, the large distance of transport in southeastern Arizona remains provisional.

\section{AGE OF THRUST FAULTS}

The geologic age of the thrust faulting, postdating dacitic volcanism of the lower part of the Salero Formation and correlative units and predating rhyodacitic volcanism of the upper part of the Salero Formation, is regionally consistent. The actual age of faulting is 75-80 m.y. in the western part of the region and, because some of the key rock units are younger to the east than the west, it may be latest Cretaceous and even Paleocene in the eastern part. The detailed basis for this age assignment has been presented by Drewes (1976a). In essence, the thrust faulting postdated the radiometrically undated dacitic rocks of the lower Salero Formation and its many correlative formations shown on figure 2 and plate 1, and also postdated the fossiliferous upper Upper Cretaceous Fort Crittenden Formation. In addition, faulting of the early phase of the Cordilleran orogeny was followed by the extrusion of radiometrically dated (mainly 72 - to 73-m.y.-old) rhyodacite tuff and welded tuff. To the east, dacitic rocks that may be correlative with the lower part of the Salero Formation may be as young as the Paleocene (55-67 m.y.). Similarly, the post-thrust stocks of Cordilleran age to the east are younger than to the west. Assuming a genetic connection between these igneous features and the thrust faulting, that faulting may also be younger to the east than to the west. In southwestern New Mexico, during a study still in progress, C. H. Thorman and I have seen indications that dacitic volcanic rocks of latest Cretaceous or early Paleocene age are thrust faulted.

\section{NORTHERLY TRENDING BASIN AND RANGE BLOCK FAULTS}

Extensional forces produced a generally northtrending set of steep faults that separate graben blocks from uplifted homoclinal blocks (fig. 4). Locally the pattern of these faults is controlled by favorably situated segments of the older northwesttrending complex faults. Amounts of movement on the order of many tens of meters to a few thousand meters are typical on individual northerly trending structures. This movement took place intermittently between Oligocene and recent time. Faulting of Oligocene and Miocene age is associated with widespread rhyolitic volcanism, and that of Pliocene and Pleistocene age with more restricted basaltic volcanism. The association of block faulting and young bimodal volcanism is typical of the Basin and Range geologic province.

The northerly trending faults form an oblique trellis pattern distinctive from the other major fault systems of southeastern Arizona. While faults that strike north are most typical of this system, particularly in the central part of the region, other faults of the system, mainly to the north and south, trend northwest; a few trend northeast. Many faults of this system trend regularly over distances of a few tens of kilometers, and then change direction rather abruptly. Locally, where the segments are short, the map pattern is zig-zag, much like a rail fence, and a 
main fault set and a subordinate or cross-fault set are recognized. Also locally, individual faults form sweeping arcs unlike the usual straight fault traces. The overall angularity of fault pattern is maintained even in this case, for the arcuate segments abut or are truncated obliquely by other faults of the northerly system.

The main faults of the northerly trending system are paired along the San Simon-San Bernardino Valley margins and along the Santa Cruz Valley margins. Somewhat similar faults also occur along parts of the San Pedro Valley margins, and are inferred to extend southward to the border of Sonora. Almost no faults of this system are found or can be inferred along the margins of the valley at Sonoita, the San Rafael Valley, or the Sulphur Springs Valley. Not surprisingly, these two groups of valleys differ in appearance; the San Simon-San Bernardino and Santa Cruz Valleys are relatively narrow, linear, and sharply bordered, whereas the valley at Sonoita and the San Rafael and Sulphur Springs Valleys are broader and less regular. The morphologic character of the San Pedro Valley lies between those of the other groups.

On the regional tectonic map (Drewes, 1980), which gives greater detail than figure 4 , the faults are seen to be largely concealed by surficial deposits, though actual exposures of the faults are to be found. While the morphology of straight, steep, and extensive mountain fronts is by itself a strong indicator of structural control, there are other indirect signs. Along the San Simon-San Bernardino Valley, cinder cones alined along the foot of the Peloncillo Mountains suggest the presence of a concealed fault. Other cinder cones along the west side of the valley are on line with exposed segments of north-trending faults in the Pedregosa Mountains. Still others on the southeast side of the Chiricahua Mountains follow an arcuate line that probably marks a concealed fault subordinate to the main range-front fault. I believe a concealed fault lies between the deep drill holes near the northeast edge of the Chiricahua Mountains and the mountain. front, because of the great thickness of gravel and young volcanic rocks encountered so close to the mountain front. One hole, for example, bottomed in gravel 2,500 $\mathrm{m}$ beneath the surface less than $5 \mathrm{~km}$ from the range front (Sabins, 1957a). Another encountered volcanic rocks, like those in the adjacent range, at depths about $1,100-1,600 \mathrm{~m}$, even closer to the mountain front. Finally, in Sonora (fig. 4), a fault scarp is exposed through a distance of tens of kilometers along the east side of the San Bernardino Valley. The combined evidence for faulting along both sides of this valley is thus as strong as any found elsewhere in the Basin and Range geologic province.

Along the edges of the Santa Cruz Valley, northerly trending faults are exposed northwest of Nogales (pl. 8) and along the northwest sides of the Santa Rita and San Cayetano Mountains (Drewes, 1971a and 1971b). Other faults of this system are exposed along subsidiary basins west of Amado (fig. 16), northwest of the Patagonia Mountains (Simons, 1974, and Drewes, 1971b), and northeast of Nogales (Simons, 1974). From the area where the main rangefront fault at the foot of the Atascosa Mountains is concealed beneath gravel deposits northwest of Nogales, to the vicinity of Amado, a strong, northtrending, steep gravity gradient shown by West and Sumner (1973) is believed to mark the concealed position of the fault. North of Amado the subsurface fault appears to curve eastward, as does the steep gravity anomaly. East of Amado the other member of the pair of faults along the Santa Cruz Valley is exposed adjacent to gravel deposits that dip toward, rather than away from, the adjacent range. Fault scarps trend northeast across the alluvial fans from this place to the north end of the mountains. A subsidiary fault, mountainward of the faulted alluvial fan southeast of Green Valley, follows an arcuate trace much like that north of Amado, both being concave toward the valley.

Northerly trending faults occur along the west side of the San Pedro Valley north of Benson. A few others occur south of Benson, and one such fault is found on the east side of the valley. The faults north of Benson strike north (Drewes, 1974), whereas the valley trends to the northwest, so these faults extend obliquely from the valley edge into the adjacent mountains. The faults that occur locally at the foot of the Whetstone (Creasey, 1967) and Huachuca Mountains (Hayes and Raup, 1968) south of Benson and at the foot of the Little Dragoon Mountains (Cooper and Silver, 1964) northeast of Benson trend parallel to the main mountain fronts but cross small bedrock masses in the foothills, where the bedrock consists of rocks that occur at much higher structural positions in the adjacent main mountain masses. These faults may be subsidiary to a main range-front fault or they may be a segment of that fault itself, but in either case they lend support to the presence of such a fault along the steep, long, and straight fronts of these ranges.

The northerly trending faults typically $\operatorname{dip} 60^{\circ}-80^{\circ}$ toward the adjacent basins. Specific locations of exposed segments of the faults and their dip values are shown on the quadrangle maps of the Santa Rita 
Mountains (Drewes, 1971a and 1971b), the Nogales area (this report, pl. 8; Simons, 1974), and the lower reaches of the San Pedro River (Drewes, 1974).

Movement on the northerly trending faults has been typically normal, and displacement has been as much as a few thousand meters. Pairs of subparallel normal faults dipping toward each other define several grabens. The structural blocks adjacent to the grabens mainly dip away from the grabens and toward each other across the nearby unfaulted, broad, irregular valleys. Thus, the overall effect of the blocks formed by the northerly trending fault system is one of three broken-crested, north-trending arches, separated by two broad, gentle synclinal troughs. This generalization is less applicable to the north and the south.

The amount of movement that resulted in the two most recent scarps is measurable commonly at about 1-2 $\mathrm{m}$ and at most is about $8 \mathrm{~m}$. One of these scarps cuts a very young red soil on the alluvial fan on the north end of the east side of the Santa Cruz graben. The other, larger scarp lies in Sonora on the south end of the east side of the San Simon-San Bernardino graben, actually outside the southeastern Arizona region (fig. 4).

By contrast, the total amount of movement on the largest fault, the one on the east side of the Chiricahua Mountains, has a magnitude of possibly a few thousand meters. This value is obtained by adding the height of the mountains above the present valley floor to the depth of a drill hole that bottomed in valley fill of an age no older than the faults. Most faults have had only a few tens or hundreds of meters of movement.

The northerly trending faults were active as early as the late Oligocene, and some segments of faults record late Pleistocene and even Holocene movement. The earliest stage of movement is recorded along the southern part of the Santa Cruz graben, on the east side of the minor fault block of the San Cayetano Mountains. Some movement on this fault is believed to predate the 25- to 28-m.y.-old volcanic rocks of the adjacent area (Drewes, 1972a).

In most places the main time of movement is seen to postdate the volcanic rocks of $25-28$ m.y. age. Many volcanic rocks of this suite, which typically form the capping rocks of tilted and offset adjacent mountain ranges, are offset by faults. Possibly some of this phase of faulting is closely associated with the effusion of these rocks, as has been illustrated in a local area of volcano-tectonic collapse of the Grosvenor Hills (Drewes, 1972b). A geographic association between mid-Tertiary rhyolite volcanism and block faulting is also apparent on a regional scale; the main volcanic fields occur in the ranges next to the well-developed grabens.

The main phase of faulting, of late Oligocene or Miocene time, is also related to the development of the present drainage network of the region. Before the end of Oligocene time the central part of the Santa Cruz graben seems not to have been present. A high area is inferred to have existed between Green Valley and Amado, from which the San Xavier glide plate slid north-northwestward several miles about 30 m.y. ago (Cooper, 1960b). The subsequent downfaulting of this high area suggests that the integration of the present Santa Cruz River is probably no older than Miocene. Before that time, the drainage of the San Rafael Valley and the upper reaches of Santa Cruz Valley flowed southward through either the broad valley of the Rio Babasac or the valley of the Rio de los Alisos (fig. 4) into the Rio Magdalena, south of the area of figure 4. With the lowering of the Santa Cruz Valley at Amado, and perhaps also further downstream, this older stream system was beheaded, and even at present the lower Sonoita Creek tributary of the Santa Cruz is cutting headward into the adjacent, higher San Rafael Valley.

Faulting and gentle downwarping also occured in the San Bernardino Valley during Pliocene-Pleistocene time. Young basalt flows are warped basinward, and the main graben appears to contain a greater thickness of these flows than the adjacent mountain flanks. The faulting of the red soil on the fans off the northern flank of the Santa Rita Mountains is estimated to have happened during the late Pleistocene.

Finally, on May 3,1887, the scarp along the east wall of the southern part of the San Bernardino Valley developed during the Sonoran earthquake (Aguilera, 1920).

The crustal stress that created the grabens may be genetically related to the localization of voluminous outpouring of the mid-Tertiary volcanic rocks. With few exceptions, the volcanic rocks occur only in the mountain ranges adjacent to the grabens. Furthermore, they are most abundant next to the most prominent and perhaps largest graben of the San Simon-San Bernardino Valley and least abundant next to the least well developed San Pedro graben. In addition, the rocks are of about the same age as the faulting; a little faulting preceded the earliest volcanism and most faulting followed it. The tensional stress that produced the northerly trending fractures appears to have provided egress to rhyolitic magma, which poured out most voluminously where the fracture system was most strongly developed (where 
the pulling apart through tension was greatest). Tensional stresses continued after the magma was depleted; hence, block faulting occurred primarily along the zones up which the magma had moved.

\section{BASIS FOR TECTONIC INTERPRETATIONS}

Evidence supporting the interpretations of the regional geologic history and of the geometry, dynamics, and age of the major kinds of structural features is based mainly on field studies, supplemented by some laboratory studies. High altitude aerial photography and special imagery was available but was found to be of little help in this region.

A field based synthesis was undertaken because initially the study was focused on resolving the question of whether or not the western part of the region was underlain by regional thrust faults of Cordilleran orogeny age. The emphasis on the west developed from an effort to provide a summary of the structural geology of a group of mountain ranges recently mapped by the U.S. Geological Survey. These include the Sierrita Mountains (Cooper, 1973), the Little Dragoon Mountains (Cooper and Silver, 1964), the Patagonia Mountains (Simons, 1974), the Santa Rita Mountains (Drewes, 1971a and 1971b), the Empire Mountains (Finnell, 1971), the Whetstone Mountains (Creasey, 1967), the Mustang Hills and Huachuca Mountains (Hayes and Raup, 1968), and the Canelo Hills (R. B. Raup, written commun., 1968). The emphasis on the Cordilleran orogeny reflected an interest in establishing the time of mineralization throughout the ranges. The question could not be resolved initially within the area covered by these mountains, because they appeared to be entirely allochthonous. Study of a wider region, where autochthonous rocks might be found, and where evaluation of style of deformation and direction and age of faulting would be more meaningful, was needed. The study grew, not only in areal extent, but also in topical breadth, because the Cordilleran thrust faults were deformed by many younger structural features and probably were guided by or cut older structural features. The progress made in understanding the geometry and age of faults was due almost entirely to this field approach.

\section{PREVIOUS FIELD STUDIES}

Compilation of previous field studies supplied much of the basic data on the distribution of rocks and structural features. The final extent of the study region was determined by the distribution of these older geologic maps: to the north of Tucson (lat $32^{\circ}$ $15^{\prime} \mathrm{N}$.) and east of the Arizona State line (about long $109^{\circ} 00^{\prime}$. W.), the available maps were fewer at the time the project was begun; to the west of Tucson (long $111^{\circ} 15^{\prime} \mathrm{W}$.) and in northern Sonora, geologic maps were almost nonexistent, except for very small scale maps based on very rapid reconnaissance.

A preliminary geologic compilation of this region, covering about $21,000 \mathrm{~km}^{2}$ provided a base for most of the study. This compilation not only indicated areas that were inadequately studied because previous work was of reconnaissance type, but also pointed out some structural patterns and anomalies, and identified some areas that could be of key significance. Above all, the preliminary map indicated the rock units that would best illustrate the tectonic development of the region. Tectonically quiescent times like the Paleozoic, with a span of about $300 \mathrm{~m} . y$. , were depicted by the same number of map units (five) required by the tectonically active Upper Cretaceous, with a span of only about 30 m.y.

Many geologists and students have contributed to the previous body of geologic knowledge of the region. In fact, the list of benefactors is so large that there is little virtue in being thorough with acknowledgements. Let me specifically acknowledge the major studies of Cooper (1959, 1960a, and 1973), of Cooper and Silver (1964), and Gilluly (1956), on which the present synthesis leans heavily. As groups of substantial contributors, I also am indebted to the students and faculty of the University of Arizona and to the geologists of the Tucson mining community. The courtesies of Mr. Vincent Roth and the American Museum of Natural History in permitting the use of the facilities at the Southwestern Research Station are likewise gratefully acknowledged. Other contributors will be cited in appropriate sections on local geology or radiometric dating.

\section{REGIONAL STRATIGRAPHIC SUMMARY}

In southeastern Arizona the kinds of rocks and the distributions of rock types are in many instances related to the regional tectonic development; therefore a general review of the rock sequence and facies variations supports certain tectonic interpretations. Most of this review of the rocks is presented as the stratigraphic chart of plate 1 , which also gives a range of radiometric ages by which the unfossiliferous rocks have been dated. This chart is augmented by a brief description of some rocks and by more extensive descriptions of a few units occurring in those detailed study areas, described in 
the section entitled "New field studies," in which stratigraphic reinterpretations have led to new structural interpretations.

The extent of current knowledge of the rocks of the Precambrian, Paleozoic, Mesozoic, and Cenozoic Eras varies considerably. Probably least is known of the Precambrian sequences; customarily all the host rock of the most ancient granitic plutons is assigned to one unit, the Pinal Schist. The Paleozoic sequence, on the other hand, is comparatively well known, and in the last decade much effort has provided stratigraphic refinement and biostratigraphic details. Our knowledge of Mesozoic and Cenozoic rocks has greatly improved in recent years and now reveals the complexity of the geologic history of the region. The key sources of data on stratigraphy are listed for each mountain range near the top of the stratigraphic chart (pl. 1); these references contain most of the other significant sources of stratigraphic data.

Like all stratigraphic charts, that of plate 1 contains some special compromises and emphases, in this instance appropriate to the tectonic objective. In addition to tabulating the rocks in the framework of geologic time, a summary is shown of tectonic conditions and activity. Specific radiometric ages or the range of a suite of radiometric ages are also presented, and rock names and descriptions are given where the stratigraphic names are uninformative. To keep time lines horizontal, the thicknesses of the units are not shown. Likewise, the space apportioned the various time-stratigraphic units varies with their importance in the regional tectonic interpretation, rather than with their relative duration. The shaded zones on the chart represent the times without known deposition at the surface, although magmas were emplaced at depth during some of these hiatuses. Here, too, relative thicknesses of the shaded zones do not reflect the time span they represent; indeed, some minor zones are entirely omitted. Shaded zones do, however, help to illustrate the chief depositional sequences and those rocks of major tectonic significance.

\section{PRECAMBRIAN ROCKS}

The most ancient rocks of the region are assigned to the Pinal Schist, which is typically a chloritemuscovite schist, but which also includes phyllite, metagraywacke, meta-arkose, metaquartzite and quartzite conglomerate, and some metavolcanic rocks. In a few places, gneissic rocks and some granitoid gneiss have been mapped with the Pinal for convenience, although alternative correlations may eventually be more attractive. Through a systematic regional review of these rocks, it may be possible to divide the Pinal into an older terrane of graywacke and siltstone and a younger one containing quartzitic and volcanic rocks. Thickness of the Pinal is unknown but probably is much more than $1,000 \mathrm{~m}$; a possible thickness of $6,000 \mathrm{~m}$ was suggested by Cooper and Silver (1964). They also suggested that the Pinal was mainly a marine deposit, and almost certainly, the clean quartz sand deposits that formed the metaquartzite mass at Bowie Mountain of the northern Chiricahua Mountains (this report, pl. 3; Sabins, 1957a) and the beds of well-rounded quartz pebbles in the Happy Valley area (Drewes, 1974) suggest intensive marine current or wave action. Conceivably the metavolcanic rocks include shallow intrusive rocks and may be associated with local fault movement.

The ancient sedimentary and volcanic rocks must have been deeply buried and deformed, for they are regionally metamorphosed and injected by large plutons of granitic magmas, and at least locally they are also folded, foliated, and lineated. The lineation is best studied in the Rincon Mountains and in the next ranges to the northwest, which fall outside of the area of the regional map (Drewes, 1980); in these places, it is largely unidirectional, striking $\mathbf{N}$. $60^{\circ}-70^{\circ} \mathrm{E}$., but locally lineation swings gradually due north and N. $20^{\circ} \mathrm{W}$. Very likely the foliation and lineation of the Rincon Mountains was enhanced by the subsequent deformation. Some of the widespread metamorphism and deformation of the Pinal largely happened during the Mazatzal Revolution, best documented in central Arizona by Anderson (1951); other features, like the intense foliation and lineation of the Rincon Mountains, reflect younger events.

The plutonic rocks of the ancient crystalline basement are varied in composition and seem to be more widespread than the schistose host rock, perhaps because some intrusions are of batholithic size. The plutonic rocks are very coarse grained in texture; for example, the Continental Granodiorite has abundant phenocrysts 2-4 cm long. Most of these rocks are granodiorite, and few are probably quartz monzonite. Some rocks have been called granite or alaskite, although usually without much petrographic study. Normal granitoid textures are most common, so the plutons were probably largely emplaced after the deformation called the Mazatzal Revolution and have not been deformed subsequently; however, one pluton in the Dos Cabezas Mountains and all Precambrian rocks of the Rincon Mountains have a gneissic texture. However, the oldest of the granitoid masses in the 
Rincon Mountains correlates lithologically with non-gneissic Continental Granodiorite in the adjacent part of the Santa Rita Mountains; hence, the age of the gneissic texture here seems to postdate the deformation of Mazatzal time, and the same may be true for the pluton in the Dos Cabezas Mountains.

Rocks of the lower part of the Apache Group, about $600 \mathrm{~m}$ thick, were the last of the Precambrian rocks deposited in the region. The Apache Group is present only in the Rincon and Little Dragoon Mountains; the rocks are more widespread and more completely preserved north of the region (Shride, 1967) and are probably eroded from the rest of the southeastern Arizona region. Both the basal Scanlan Conglomerate Member of the Pioneer Shale and the basal Barnes Conglomerate Member of the Dripping Spring Formation are present. Pioneer Shale is a redbed sequence of siltstone and argillite; welldeveloped shaly partings are uncommon. The Dripping Spring Formation is a reddish-brown arkose and conglomeratic sandstone. From evidence developed north of the region, these rocks are believed to be of marine origin. After their deposition in southeastern Arizona, as elsewhere, they were intruded by diabase sills and dikes, which to the north have been dated as 1,100-1,200 m.y. old by Neuerburg and Granger (1960) and by Silver and Damon (as reviewed by Shride, 1967, p. 77).

\section{PALEOZOIC ROCKS}

The rocks of Paleozic age comprise a uniform sequence throughout southeastern Arizona, as shown by plate 1 . The sequence consists of two major, concordant depositional sheets, separated by a disconformity lasting roughly through the Ordovician and Silurian Periods. Only to the extreme east is some Ordovician rock preserved, and still farther east greater amounts of the Ordovician and Silurian rocks are present. Other disconformities are reported in some mountain ranges at higher horizons but, in general, there is insufficient faunal control to delimit them adequately. Most of these marine formations are fossiliferous.

The most essential lithologic features of the Paleozoic sequence are indicated by the formation names shown on plate 1 , and they are only briefly elaborated upon here. The Middle Cambrian Bolsa Quartzite is typically a thick-bedded, coarse-grained, gray to brown to purplish-gray, cliff-making quartzite about 75-200 m thick. Arkosic beds occur at some horizons, and many beds are sandstone rather than quartzite. Conglomerate lentils occur near the base, and in some areas they are scattered through the lower third of the formation. Eastward the Bolsa is time-transgressive; it is lithologically correlative with the younger Coronado Sandstone in the easternmost part of the study area, and with the Bliss Sandstone in New Mexico (Hayes, 1972, fig. 2; Hayes and Cone, 1975).

The Middle and Upper Cambrian Abrigo Formation, in places also referred to as the Abrigo Limestone, comprises alternating units $230-290 \mathrm{~m}$ thick of shale, thin-bedded sandstone, and thinbedded limestone. Locally it also includes some beds of quartzite and, to the east, a gradually increasing amount of dolomite. In the Swisshelm, Chiricahua, and Pedregosa Mountains, the Abrigo Formation is difficult to separate from the Lower Ordovician El Paso Dolomite, and their separation on plate 5 may deserve further scrutiny. In several places where the Abrigo Formation has been mapped in detail, it is seen to be disharmonically deformed with respect to its contacts, so thickness measurements must be used with special care.

The Upper Devonian Martin Formation, 60-130 m thick, is also of mixed lithology; gray limestone and brown dolomite are the main rock types, and some sandstone beds are generally also present. To the east, in the northern part of the Chiricahua Mountains and the Dos Cabezas Mountains, the Upper Devonian Portal Formation of Sabins (1957b) is a time equivalent of the central part of the Martin Formation, and in the intervening Swisshelm Mountains the term Swisshelm Formation has been applied. In a general way, the dolomite, limestone, and marly dolomite lithologies present in the Swisshelm Formation of Epis, Gilbert, and Langenheim (1957) are similar to those of the Martin. Thus the variations of lithology that do occur suggest local facies differences perhaps not justifying the use of different formation names. Furthermore, the reported sequence in the southern part of the Swisshelm Mountains is abundantly faulted (pl. 5); hence, the designated type section is of questionable value.

The Upper Devonian Portal Formation of Sabins (1957b), 60-100 $\mathrm{m}$ thick, comprises thin-bedded shale and limestone and some fissile black shale and has affinities with the Upper Devonian Percha Shale of New Mexico. The Portal Formation thus does deserve a name different from the Martin, and it was Sabins' judgment that a new name is warranted because of the greater preponderance of black shale in the Percha. It is noteworthy that in the eastern ranges in which the Cochise plate is recognized, the shale-rich, dolomite-free lithology of the Portal occurs in the Hidalgo plate, whereas the dolomite- 
rich Martin Formation and its equivalent in the Swisshelm Mountains are found in the Cochise plate. The seeming abruptness of this change may have been enhanced by the northeastward movement of the upper allochthon with respect to the lower allochthon. I doubt, however, that there are sufficient Devonian sections available in the critical area of eastern Arizona to adequately verify this possibility through a detailed stratigraphic study.

The Mississippian Escabrosa Limestone is a bold, cliff-forming, thick-bedded, coarse-grained, cherty, crinoidal formation, $160-260 \mathrm{~m}$ thick, that is recognized across all of southeastern Arizona. Some of its lithologic features vary vertically through the formation, particularly within the upper part of the formation, and so the Mississippian rocks (and also those possibly of earliest Pennsylvanian age, as mapped in a few ranges) have locally been divided. However, because of the local extent over which these subdivisions are recognized and the relatively subtle lithologic variations on which they are based, it would seem more appropriate to regard them as members rather than formations. For example, in the Peloncillo Mountains, Armstrong and Silberman (1974) raised the rank of the Escabrosa to a group comprising the Keating Formation and the overlying Hachita Formation, based on relatively subtle distinctions. In a second case, the Black Prince Limestone of Mississippian and Pennsylvanian(?) age in the Little Dragoon and Whetstone Mountains has been recognized or mapped in only a few areas because the differences between it and the adjacent formations are so subtle. In both cases the subtle lithologic variations and local application seem appropriate to member-rank units, but formal redesignation is not proposed in this report.

The Upper Mississippian Paradise Formation is a shaly limestone as much as $50 \mathrm{~m}$ thick that overlies the Escabrosa Limestone in the northern Chiricahua Mountains (Sabins, 1957a, and the section of this report, "Central Chiricahua Mountains") and also over an extensive area in southwestern New Mexico (Gillerman, 1958; Zeller and Alper, 1965; Zeller, 1970).

The Pennsylvanian Horquilla Limestone is another widespread and uniform unit, typically $400-460 \mathrm{~m}$ thick. It is a thin-bedded to moderately thick-bedded limestone with intercalated units of siltstone or marlstone that increase in relative thickness upward in the formation. The limestone is mostly light gray to pinkish gray and cherty. In a few places it contains reef-like lenses of coarsegrained, thick-bedded limestone that closely resemble the Escabrosa Limestone, except for faunal content.

The Pennsylvanian and Permian Earp Formation occurs throughout southeastern Arizona and is a unit of special importance because it is structurally incompetent. Over most of the region the formation is mainly a marlstone or siltstone; sparse light-gray limestone and dolomite beds are intercalated in the marlstone or siltstone. In the Peloncillo Mountains and farther east, the limestone content increases upsection; consequently, Armstrong and Silberman (1974) include Horquilla-like lithology in the lower part of their Earp, whereas Kottlowski (1960, pl. 9) retained the position of the Horquilla-Earp contact to coincide with that at the type localities in Arizona, a course that appears to be more practical in the field. One or two beds of red jasper or chert-pebble conglomerate are widespread distinctive marker units within the Earp. The reported thickness of the Earp ranges from less than $200 \mathrm{~m}$ to $670 \mathrm{~m}$. In many places, bedding-plane faults occur next to or within the Earp. Typically these can be seen only through the disharmonic relations between marker beds within the formation and the basal or overlying contacts. In other places, cross faults cause abrupt changes in thickness in only one of the adjacent formations. In thrust-faulted terrane the Earp inevitably is structurally disturbed, and so the reported variations in thickness in Arizona are most likely due to tectonic causes and not to depositional conditions.

The Lower Permian Colina Limestone is a darkgray, sparsely cherty rock generally reported to be 80-210 $\mathrm{m}$ thick. In places where it is fairly thin, the overlying Epitaph Dolomite is usually thick, so there may in part be a lateral facies relation between them.

The Lower Permian Epitaph Dolomite is a widespread formation of mixed lithology, of which dolomite is most commonly exposed. Dark-gray, coarse-grained and light-gray, fine-grained varieties of dolomite occur, as well as dolomite marlstone. Some sections contain gray limestone and argillic units, and in a few places gypsum is found in small quantities. In structurally disturbed sections the marlstone and gypsum-bearing beds are likely to be very thin or locally missing, and in the northern part of the Santa Rita Mountains (Drewes, 1972a, pl. 4) the gypsum, probably derived from within the formation but possibly coming from an unknown lower structural level, has flowed tectonically into small pods and pipes. The large reported range of thickness of the Epitaph (about 0-350 m) may thus reflect not only facies relations to the Colina Limestone, but also local structural thinning. 
The Lower Permian Scherrer Formation is commonly seen to be a distinctive very light colored, fine-grained quartzite 40-290 m thick. In places where thrust faulting has not greatly disturbed the rocks, a basal red siltstone or mudstone member and a thin, medial, light-gray dolomite unit are also found with the dominant quartzite lithology. Where the rocks have been thrust faulted, parts of this formation are commonly faulted out. Thus the locally reported succession of the members of the formation and their variation in thickness may be entirely of tectonic origin.

The Lower Permian Concha Limestone is generally the youngest of the Paleozoic formations in southeastern Arizona. It is a medium-dark-gray, cherty, fine-grained limestone, $180-190 \mathrm{~m}$ thick, that typically forms a bold outcrop zone. Some units contain as much as 25 percent chert, commonly of dark-gray color.

The Lower Permian Rainvalley Formation is locally the youngest of the Paleozoic formations and is found overlying the Concha in only a few of the mountain ranges of the central and northwestern part of the region. Much of the rock is a medium-gray limestone that somewhat resembles the Concha. However, the Rainvalley contains intercalated beds of light- to medium-gray dolomite and of brown sandstone. No more than about $130 \mathrm{~m}$. of this formation, of latest Wolfcampian or of Leonardian age, is found unconformably beneath rocks of Triassic or younger age. This unconformity marks a widespread marine regression and the initiation of a new tectonic regime.

\section{MESOZOIC ROCKS}

The depositional record of the Mesozoic age is markedly different from that of the Paleozoic. The rocks are mainly of terrestrial origin, with abundant volcanic and coarse clastic formations and very sparse amounts of limestone. Thicknesses of formations vary drastically from place to place, and the sites of thickest sedimentation vary from formation to formation, apparently reflecting shifting centers of deposition and variable amounts of subsequent erosion between local uplifted blocks. Few of the rocks are fossiliferous and consequently most dating has been through geologic relations and radiometric dates.

A thick body of volcanic and clastic rocks, the Mount Wrightson Formation and its correlative $\mathrm{Ox}$ Frame Volcanics, was deposited during Triassic time in some of the western part of the region. These rocks were described by Cooper (1971), Drewes (1971c), and Simons (1972) and are interpreted by
Drewes (1972a) to be deposited in a northwesttrending fault trough extending from at least the Patagonia Mountains to the Sierrita Mountains. Not only are the 3,000-m-thick deposits of rhyodacite and andesite volcanics and intercalated eolian quartzite restricted to a narrow belt, but intercalated conglomerate in the center of the sequence in the Santa Rita Mountains contains detritus of Precambrian granodiorite, apparently derived from an adjacent, upfaulted, deeply eroded block.

$A$ red-bed unit hundreds of meters thick extends over much of the western part of the region and consists mainly of mudstone and siltstone, but also contains some well-rounded pebble conglomerate, a small amount of rhyodacite or andesite volcanics, and a trace of limestone. Typically, these red beds were considered to be part of the Lower Cretaceous Bisbee Formation, for they have a general similarity with some beds of the Bisbee, but subsequently (Hayes and Drewes, 1968) they were placed with the Triassic Rodolfo Formation, Recreation Red Beds of Brown (1939), or Gardner Canyon Formation because of direct radiometric dates obtained in the Santa Rita Mountains, supplemented indirectly by dates on rocks that intrude or overlie the red beds. Although individually these radiometric dates are not of the greatest reliability because of the methods used or the condition of the rock, they are reasonably consistent with each other and in places also with the geologic record. For example, in the Sierrita Mountains the red beds are intruded by a Jurassic stock, and in the Canelo Hills and Mustang Mountains they underlie volcanics dated as 173 m.y. old. Therefore, the older age now assigned to the red beds is accepted.

Stocks of very coarse grained monzonite and monzonite porphyry were intruded near the end of the Triassic in several areas. These have been studied in some detail in the Santa Rita Mountains (Drewes, 1976b), where they are deficient in quartz or in both quartz and potassium feldspar, as they appear to be elsewhere. The Canelo Hills Volcanics and the Walnut Gap Volcanics (also called Walnut Gap Formation), which consist mainly of rhyolitic volcanic rocks but also contain some clastic rocks, seem to be correlative rocks of latest Triassic or Jurassic age. The Canelo Hills Volcanics reach a maximum thickness of about $2,600 \mathrm{~m}$ in the southern part of the Canelo Hills. In the Huachuca Mountains they contain large exotic blocks derived from Paleozoic formations.

Near Middle Jurassic time, six large stocks-one perhaps even of batholith size-were emplaced in the western and central parts of the region. Most of them 
are called granite, although all of them seem to include at least some quartz monzonite; but they are more granitic than any of the younger stocks of the region. Reported lead-alpha and potassium-argon radiometric dates of the stocks span about 15 m.y. Despite the lack of precision of some of the available dates, they are generally consistent and in detail may be younger westward, a pattern unlike that of the ages of the Cordilleran stocks.

The next overlying depositional sequence, emplaced following a regional hiatus spanning much of the Jurassic, is of Early Cretaceous age. It consists of a relatively local assemblage of volcanic and clastic rocks, probably of earliest Cretaceous age, overlain by a widespread assemblage of clastic rocks of Aptian and Albian (late Early Cretaceous) Age. The volcanic and clastic rocks of earliest Cretaceous age are recognized as the Temporal and Bathtub Formations (Drewes, 1971c) in the Santa Rita Mountains, where a composite maximum thickness of about $1,800 \mathrm{~m}$ is attained. In the Huachuca Mountains similar rocks form a thick and unusual basal part of the next overlying formation of late Early Cretaceous age. The volcanic rocks of this sequence are mostly of andesitic composition, but in the Santa Rita Mountains they also include rhyolitic units.

The clastic rocks of late Early Cretaceous age are generally assigned to the Bisbee Group or Bisbee Formation. (Throughout this report the stratigraphic rank assigned the Bisbee rocks reflects the current local usage. Typically, where the Mural Limestone is found, the rocks can be divided into four units of formation rank: the Glance Conglomerate, Morita Formation, Mural Limestone, and Cintura Formation (ascending order), which collectively form the Bisbee Group; where the Mural is absent, the Bisbee is regarded as a unit of formation rank that locally contains a thin, lenticular basal conglomerate, the Glance Conglomerate Member.) The Bisbee rocks are mainly a repetitious sequence of shale and siltstone with intercalated arkosic sandstone and quartzite, about $1,700 \mathrm{~m}$ thick. The colors of the rocks commonly are dark brown or olive gray to reddish brown or dark gray. In some mountain ranges to the north and east, such conglomerate is scattered at many horizons in the lower half of the Bisbee. Near the type locality at Bisbee, the sequence contains a conspicuously cliffy limestone, the Mural Limestone, within a zone of thinner limestone beds. The Mural thins to the north, east, and west but persists far into Sonora to the south. Biostromal features account for much of the lenticularity of the limestone units and were described in detail by Hayes (1970a). In the north- western part of the region, where the Mural Limestone is absent, the Bisbee rocks are dominantly arkose and are assigned names such as the Amole Arkose (Brown, 1939) or Angelica Arkose, which are not part of the Bisbee, but in some places typical Bisbee lithologies are still recognizable.

A regional hiatus separates the Lower Cretaceous from the Upper Cretaceous sequences. Mostly this hiatus is described as a disconformity, but in the Huachuca and Santa Rita Mountains it may be a subtle angular unconformity. A hiatus appears at this time interval in several places around the southern Rocky Mountains and indicates the initial crustal movement of the Cordilleran orogeny in southeastern Arizona (Drewes, 1972a). The underlying rocks record deposition during relatively stable crustal conditions; the overlying ones indicate growing crustal instability related to orogeny.

The lowest unit of Late Cretaceous age is the Fort Crittenden Formation and its several unnamed or informally named stratigraphic equivalents shown on plate 1. In most places these rocks contain conglomerate, the clasts of which include detritus of Bisbee Group origin. Some fossiliferous black shale occurs low in the Fort Crittenden in the Santa Rita Mountains, and near the top of the formation there are some beds of fanglomerate and a few of rhyolitic tuff. In the Santa Rita Mountains the formation is about $1,600 \mathrm{~m}$ thick, but elsewhere in southeastern Arizona it is much thinner.

The next overlying unit of Late Cretaceous age is typically a volcanic deposit, consisting of andesitic or dacitic flow breccia overlain by rhyodacite welded tuff. A variety of formation names are applied to these rocks, as shown on plate 1 , but I most commonly use the term Salero Formation. The andesitic or dacitic rocks are too strongly propylitized to be radiometrically dated, but the rhyodacite has been dated as about $72 \mathrm{~m} . \mathrm{y}$. old in several mountain ranges of the western part of the region and in other places farther west. From the Dragoon to the Tucson Mountains these volcanic rocks contain exotic blocks, typically of small size, but locally in spectacular swarms of inclusions tens and even hundreds of meters long. The various volcanotectonic origins proposed for these inclusions (Gilluly, 1956; Simons and others, 1966; Mayo, 1971; Drewes, 1971c) all require or imply a highenergy environment. Small stocks are spatially and temporally associated with many centers of abundant volcanic rocks, and it is likely that the volcanics themselves were extruded from many separate vents. 
In a few mountain ranges of the western part of the region, clastic and volcanic rocks that overlie the rhyodacite welded tuff may also be of Late Cretaceous age.

At the close of the Cretaceous (65-69 m.y. ago), many stocks were emplaced in the region. They range in composition from diorite to quartz monzonite and in texture from fine to coarse grained and porphyritic. Most of these stocks are composite bodies and few of them have associated small amounts of mineralization.

\section{CENOZOIC ROCKS}

Sedimentary and volcanic rocks of Cenozoic age are widespread in southeastern Arizona, and the volcanic rocks in particular tend to cover extensive areas. Also, many stocks and smaller intrusive bodies of the older formations were emplaced, especially in the western part of the region. Most of the mineralization of the region was associated with certain intrusive rocks of early Tertiary (Paleocene) age, and a small portion is of Oligocene age. Few of the subareal rocks form widespread formations, because they were deposited in basins of local extent or were ejected from diverse vents. Most stocks are also smaller than older stocks, probably because they are exposed at shallower levels.

Volcanic and sedimentary rocks were deposited during the Paleocene, more or less contemporaneously with the emplacement of some nearby late Cordilleran stocks. Although the volcanic rocks are mostly of dacitic or andesitic composition, a few rhyolitic tuffs are also present. Most of the clastic rocks were derived from these volcanic rocks; some are arkosic sandstone or conglomerate. Although generally propylitized, the dacitic rocks seem less intensely altered than does the dacitic breccia of Late Cretaceous age. One andesitic flow of the Tucson Mountains has been dated as Paleocene by radiometric means, and a few others of the western part of the region have been assigned a Paleocene or Paleocene(?) age through their geologic relations to dated intrusive rocks.

Granodiorite and quartz monzonite stocks of Paleocene age are abundant; a few to the west are large, but most of them are small. Some of the small bodies have fine-grained and porphyritic textures; these typically have associated base metal mineralization and are informally referred to as ore porphyries. Petrographic and chemical descriptions of a sequence of intrusive rocks were presented by Drewes (1976b). Several dike and vein swarms may also be of early Tertiary age, and some of these veins are mineralized.
Few rocks of Eocene age are known in southeastern Arizona. Volcanic rocks radiometrically dated as 39 m.y. old are reported in the Tucson Mountains and Mustang Mountains area, and possibly some of the sedimentary rocks that underlie Oligocene volcanic rocks are this old, too.

Rocks of Oligocene and Miocene age include abundant volcanic and clastic types and some stocks. The volcanic rocks are mainly rhyolite to rhyodacite and they are chiefly tuff, welded tuff, and agglomerate. In a few places some dacitic volcanic rocks also occur, commonly beneath the rhyolitic rocks. Vitric and near-vitric textures are common, so much of the petrographic data comes from the ubiquitous phenocrysts. Volcanotectonic collapse structures are reported from several of the thicker volcanic piles (Marjaniemi, 1968 and 1969; Drewes, $1972 a$ and $1972 b)$. In the northwestern quarter of the region, some very coarsely porphyritic basaltic andesite, informally referred to as the turkey track porphyry by Cooper (1961), forms flows, dikes, and plugs. Clastic rocks underlie some of the volcanic deposits and are intercalated in others. In a few places where the volcanic rocks are absent, deposition of clastic rocks seems to have been continuous through Oligocene and Miocene time. Fine-grained, pinkish-gray playa deposits, a few with gypsum or anhydrite, occur in some basins. Nearly $3,000 \mathrm{~m}$ of these playa deposits and intercalated tuffaceous beds are reported from a drill hole in the Tucson basin. Other clastic rocks contain megabreccia deposits and fanglomerate. Over large areas these volcanic and clastic rocks are structurally little disturbed, but in places they are tilted and are cut by normal faults and glide faults.

A few intrusive rocks are also of mid-Tertiary age. Stocks of granodiorite occur in several mountain ranges, commonly near volcanic fields. Some rock masses in the Chiricahua Mountains appear to have textural and structural features of both extrusive and intrusive type; they may be epizonal stocks or laccoliths that have breached the surface (Drewes and Williams, 1973). Still others are vitric plugs, dikes, and laccoliths.

Deposits of Pliocene and younger age differ from those of mid-Tertiary age mainly in having more abundant clastic rocks and fewer volcanic rocks. In general the clastic rocks of this age are coarser and grayer than the older deposits. Playa deposits, including lacustrine beds, beach gravel, and dune sand, occur near Willcox in the Sulphur Springs Valley. An extensive field of basalt of late Pliocene and Pleistocene age underlies the San Bernardino Valley, and similar lava also occurs at scattered 
localities east of the Swisshelm Mountains and between the Tombstone Hills and the southern end of the Dragoon Mountains.

\section{RADIOMETRIC AGES OF ROCKS}

Radiometric dates are available for more than 130 rocks of southeastern Arizona; some of these are new dates and others have been reported previously. This extensive support from the geochronometric laboratories has been a tremendous asset to the regional tectonic study because many of the Mesozoic and Tertiary rocks are igneous, because few of the sedimentary rocks are fossiliferous, and because the Mesozoic and Tertiary geologic record varies greatly throughout the region.

Some of the rocks were dated simply to obtain their ages, others were dated to obtain the age of movement on nearby faults, and still others were dated to assess the ages of associated mineralization or metamorphism. With such varied objectives for dating the rocks and with the complexity of the geologic history of the region, some attempts at dating added more questions than they answered. But in all, only a few of the dates obtained remained of little value because of unresolved conflicts with other geological data, and these have not been used in the tectonic synthesis. On the other hand, the dates here presented need not all be "correct," in the sense that they accurately date the geologic event they appear to record, but they are in accord with the relative ages of events shown through local geologic relations or they are substantiated by other radiometric dates.

The available radiometric dates were obtained from several laboratories and were produced over a span of about 20 years, during which time dating methods, techniques, and decay constants have changed. Much of the early work on $\mathrm{Pb}-\alpha$ dating was done by T. W. Stern, and that on K-Ar dating by S. C. Creasey. Many of the more recent K-Ar dates and the Rb-Sr dates were obtained by R. F. Marvin, Harold Mehnert, and C. E. Hedge, and are summarized by Marvin and others (1973). Numerous other dates were obtained from the laboratory of P. E. Damon at the University of Arizona; these are presented in a series of annual progress reports to the U.S. Atomic Energy Commission, and many of them appear in such topical papers as those by Damon and Bikerman (1964) and Bikerman and Damon (1966). Using currently accepted decay constants generally tends to increase the reported $\mathrm{K}-\mathrm{Ar}$ and $\mathrm{Rb}-\mathrm{Sr}$ ages by about 2 percent. Thus, where inferred ages of geologic events reported herein are substantially based on radiometric ages, the events may prove to be slightly older than reported here. Most recently, a few fission-track ages (not, strictly speaking, radiometric ages, but herein treated as such for convenience) have been obtained from C. W. Naeser (written commun., 1976, 1977, and 1978). Collectively, the work of these laboratory investigators has proven to be as useful as that of the many paleontologists, too numerous to acknowledge here, whose efforts have helped to develop age controls of other parts of the stratigraphic sequence.

The chief effort of the present study is to place the radiometric dates in a readily apparent geologic context. The reporting of the analytical detail has been or will be made by the laboratory investigators, and analyses of the significance of specific age determinations have generally been covered in reports on local areas, or in some cases remain unreported. The radiometric data that are used in support of the regional tectonic synthesis are shown first on the tectonic map (Drewes, 1980) at individual collection sites, together with the calculated age, reported to the nearest million years. The ages are also shown in this report on plate 1 next to the appropriate formation, given in the same manner except that simply a range of ages is presented where three or more dates were obtained from a single unit.

Some of the dates shown in this manner on the map and the stratigraphic correlation chart seem to present a conflict with the mapped age of the rocks. They should, however, be viewed as useful dates in that, taken with support of other evidence, a plausible explanation is available of the apparent anomaly. A suite of radiometric dates from the core of the Rincon Mountains is a case in point. Most of the radiometric dates are about 25 m.y., although individual specimens yielded dates such as 35,46 , and greater than 295 m.y., and another one is reported as "possibly Precambrian"; yet the rocks are mostly here assigned to the Precambrian X Pinal Schist or the Precambrian Y Continental Granodiorite cr Wrong Mountain Quartz Monzonite (initially placed by me as Precambrian Y, but now assigned a Cretaceous or Tertiary age), all of the Santa Catalina Group. The assigned ages are based mainly on lithologic correlation with rocks in less deformed areas nearby, whereas most of the radiometric ages record a subsequent local age of cooling following a young thermal event. The one radiometric age of more than $295 \mathrm{~m} . \mathrm{y}$., while providing an unsatisfactory age because of an inadequate $\mathrm{Sr}^{87} / \mathrm{Sr}^{86}$ ratio (C.E. Hedge, written commun., 1975), does suggest that, in one of several alternative ways, the rock retains a remnant of a prior 
history. And since Paleozoic granitoid rocks are unknown in the region, Precambrian age of contaminants of the rock is plausible. Another specimen, collected from the Santa Catalina Mountains about $25 \mathrm{~km}$ northeast of the site from which the rock giving an apparent Paleozoic age was obtained, also seems to record a prior history of crystallization. Among a group of young ages (of recrystallization), Damon, Erickson, and Livingston (1963) reported a $\mathrm{Rb}-\mathrm{Sr}$ age of $160 \mathrm{~m} . \mathrm{y}$. for a rock resembling the Continental Granodiorite. Accordingly, I find these few old radiometric ages useful indicators of the likely origin of these rocks, even though they are not an accurate measure of either initial crystallization or later recrystallization.

\section{NEW FIELD STUDIES}

Review of the geology of key areas provides much new data bearing on a regional tectonic synthesis. The first areas reviewed were selected because the reported structures were anomalous to those of the region, because of errors on existing maps or structure sections, or because new data could probably be obtained with a little additional effort. As the study neared completion, additional areas were remapped because they seemed to require anomalous interpretations in the regional structure sections. In each case, specific objectives were pursued and commonly mapping was ended when they were obtained. In a few instances, however, the new data obtained by the local studies were so critical to the whole effort that the extent of the local map areas was expanded. Whereas some of the local maps thus cover only a few square kilometers, in the Rincon Mountains the two small areas initially reviewed were first supplemented by four more areas, then were expanded to connect them, and finally enlarged again to cover the entire Happy Valley quadrangle (Drewes, 1974) and Rincon Valley quadrangle (Drewes, 1977).

Where new structural interpretations resulted from remapping, the new map was prepared at the same scale as that of the original map or larger. In places, reconnaissance mapping sufficed, but more commonly the new maps were prepared at scales of $1: 24,000$ or even $1: 12,000$. Inasmuch as areas were generally abundantly or even complexly faulted (complex here indicating multiple times of movement and even diverse kinds of movement), the rate of mapping usually was $1-3 \mathrm{~km}^{2}$ per day.

The local reviews led basically to four kinds of new information or ideas. In several mountain ranges the reported style of deformation was reappraised. In many places, interpretations of the kind of geologic contacts were changed. In a few places, revisions of stratigraphic assignments led to structural reinterpretations. And in scattered localities, previously unreported observations were made that were pertinent to the regional synthesis. In the following sections these revised maps are presented, along with only sufficient descriptive data on the rocks to support the new conclusions.

\section{REINTERPRETATIONS OF STYLES OF DEFORMATION}

In some places the reported styles of deformation are reinterpreted. Imbricate thrust faults, rather than the reported isoclinally folded thrust faults, are believed to have produced the structural complexities of the northern parts of the Dragoon and Chiricahua Mountains. And in southern parts of the Dragoon and Swisshelm Mountains, the rocks are seen as normally dipping homoclinal sequences, rather than major overturned or recumbent folds.

As a result of these reinterpretations, the structural picture of the region is simplified and the apparent conflicts of inferences in the literature, such as direction of transport or age of thrust faulting, are eliminated. In addition to clarifying some difficult local structural situations, remapping has led to new information on fault ages, geometry, and kinematics. And finally, the remapping provides a uniformity to the interpretation.

\section{NORTHERN DRAGOON MOUNTAINS}

The rocks of the northern part of the Dragoon Mountains have been shown by Gilluly (1956, pl. 5), at a scale of $1: 62,500$, to be complexly faulted, folded, and extensively metamorphosed. The reported occurrences of tightly to isoclinally folded rocks on a large scale and of tightly folded thrust faults are of special interest to the tectonic synthesis. Furthermore, Gilluly's map shows an intriguing thrust fault, part of which is concealed beneath its own upper plate. In order to verify or clarify these structural features, an area of about $20 \mathrm{~km}^{2}$ of the northeastern corner of the St. David quadrangle and northwestern corner of the Pearce quadrangle was remapped at a scale of 1:24,000 (pl. 2). Most of this effort was directed toward the thrust-faulted and largely metamorphosed terrane in the central part of the area. The border areas were adapted in part from Gilluly's map, but discrepancies between Gilluly's and my interpretations there suggest that additional mapping is warranted.

The northern part of the Dragoon Mountains is underlain by arkosic and granitoid rocks of Precambrian age, the full sequence of Paleozoic 
rocks up to the Epitaph Dolomite, the Bisbee Formation represented in two facies, dikes of lamprophyre and of porphyritic rhyolite, and surficial deposits of Tertiary and Quaternary age that are of little consequence here.

The character of some of the Precambrian rocks is seen to be different from that which was originally reported; granitoid rocks are less widespread, and arkose, arkosic conglomerate, and phyllitic metasedimentary rocks are more widespread. The arkosic rocks probably were derived from a granitoid parent rock like that exposed in the adjacent area; so even prior to metamorphism, the contact between them may have been subtle. This lithologic reinterpretation, however, is of little consequence structurally, except that the subtle bedding in the meta-arkose is subparallel to the tectonically intercalated upended slices of Paleozoic rocks along Jordan Canyon. The arkosic and phyllitic rocks are assigned to the Pinal Schist rather than to the Bisbee Formation, because there are similar rocks present in the Pinal in the Bowie Mountains area of the northern Chiricahua Mountains (pl. 3) and also low on the southwest side of the Johnny Lyon Hills (Cooper and Silver, 1964; Drewes, 1974), and because there is no resemblance between the two local facies of the Bisbee and the meta-arkose and phyllite.

The Paleozoic formations are much like those of the adjacent mountain ranges described by Gilluly, Cooper, and Williams (1954) and Cooper and Silver (1964) except that they are metamorphosed and their thicknesses are variable and commonly thinner, owing either to metamorphic flowage, tectonic shearing, or both. Some of the formations were farther from the source of the heat or were sufficiently refractory to the metamorphism to have escaped obvious changes, and so are not redescribed here, but a few features of the other formations are noteworthy. The Abrigo Formation is brownish-gray indurated siltstone, sandstone, and quartzite, containing intercalated beds of impure marble and tactite. The Martin Formation consists of brown dolomite marble, tactite beds, and some sandstone and quartzite. The Escabrosa Limestone is nearly white, massive or thick-bedded, very coarse grained, chert-bearing marble. By contrast, the Horquilla Limestone is light-pinkish-gray, thin-bedded, finegrained limestone. Low in the Horquilla are two thin beds of conglomeratic phyllite or argillite, and in the upper half of the formation is much pinkish-gray metasiltstone. Fusulines are preserved in the Horquilla Limestone of the southeastern part of the area.

In general the Bisbee Formation of the northern Dragoon Mountains unconformably overlies the
Epitaph Dolomite, although in most of the area of plate 2 it is in fault contact with various Paleozoic formations. The Bisbee occurs in two lithologically distinct facies, which have been juxtaposed by movement along the Fourr Canyon thrust fault. The eastern facies comprises a thick sequence of cobble and boulder conglomerate and some interfingering reddish-gray siltstone. This facies also contains lenses of megabreccia hundreds of meters long and tens of meters thick, as well as stray clastic blocks as much as $20 \mathrm{~m}$ long, derived from a Paleozoic rock source. In contrast, the western facies comprises a thick sequence almost entirely made up of dark-gray fissile shale and siltstone and some intercalated light-brownish-gray sandstone. The thin basal limestone-cobble and -pebble conglomerate is typical of the Glance Member, and only a few lentils of conglomerate appear higher in the sequence. Some thin beds of limestone laminated in paper-thin layers occur at a few horizons near the middle of the sequence, and a single thin but persistent bed of purplish-gray argillite is found in the southeast quarter of section 9. To further contrast these lithologic facies, the eastern conglomerate-rich Bisbee is metamorphosed, whereas the western conglomerate-poor facies is unmetamorphosed.

Two groups of dikes cut the Bisbee Formation and older rocks. Small dikes of variously textured lamprophyre that are moderately altered and hence radiometrically undatable are assigned a Cretaceous or Tertiary age because of their similarity to other dikes of probable late Cordilleran age elsewhere in the region. Thicker and longer dikes of rhyolite porphyry also intrude the rocks, and some have been injected along faults. Phenocrysts are few, small, and altered, so the dikes are not radiometrically datable. These dikes are assigned a mid-Tertiary age, because they are abundant near the midTertiary Stronghold stock $2 \mathrm{~km}$ to the south of the area of plate 2 .

Both on Gilluly's (1956) map and on plate 2 of this report, the metamorphosed eastern facies of the Bisbee Formation is shown to alternate with the Paleozoic formations. This alternation of units had been explained as resulting from tight folding, but I feel that an alternate explanation of imbricate thrust slices fits the field relations better. The crux of this interpretive difference lies in the local sequence of the units, for the metamorphism has obliterated primary sedimentary indicators of the position of the tops of beds and has recrystallized any signs of older faults that may have been present. The sequence of units shown on structure section $A-A^{\prime}$ of plate 2 is asymmetrical, as is apparent by following the section from east to west as far as the westernmost 
sliver of Bisbee Formation. The stratigraphic sequence is: Colina, Epitaph, Bisbee; Earp, Colina, Epitaph, Bisbee; Horquilla, Earp, Colina, Epitaph, Bisbee. In each of the three suites of formations the top is to the west. Had these rocks been folded, symmetrical sequences would occur, such as hypothetical units $a, b, c, b, a$. And indeed, along the northern edge of plate 2 , near the center of section 34 , some small folds do occur disharmonically within the imbricate structural sheets.

Farther west along structure section $A-A^{\prime}$, there is a reversal of the sequence order but, despite this change in position of the tops of the sequence, there is not symmetry as of a simple fold, for the units are: Horquilla, Escabrosa, Martin, Abrigo, Bolsa, Pinal; and Martin (just south of the plane of the section), Abrigo, Bolsa, Pinal. The position of the reversal of sequence order is interpreted to be a major thrust fault, and thrust faults separating the smaller suite of rock are minor imbricate bedding-plane thrust faults. The folding that seems to be required by the sequence reversal along the major fault may be a large-scale drag fold that has a westward-dipping fold axis and overlies a major thrust fault. On the regional map (Drewes, 1980), the major fault is inferred to be the Cochise thrust fault, and the reversal of the upper plate position (shown by the sawteeth) appears restricted to the terrain between the Dragoon tear fault to the north and the Stronghold stock to the south.

In the Fourr Canyon area, the upended imbricate structures and the postulated east limb of a large drag fold in the Cochise thrust plate are overlain and truncated by yet another thrust plate of the unmetamorphosed Bisbee western facies. This highest of the local thrust faults, the Fourr Canyon thrust fault, dips only moderately to the west and northwest, but along the northwest side of the plate where the fault is intruded by a rhyolite dike, the steep dip of the dike suggests that the fault, too, is steep and southeast-dipping. Probably this steep segment of the fault is actually a tear-fault segment, for it trends about at right angles to the axes of many of the small folds in the Fourr Canyon plate.

\section{NORTHERN CHIRICAHUA MOUNTAINS}

The rocks at the north end of the Chiricahua Mountains are reinterpreted to be imbricately thrust faulted, rather than deformed by the isoclinally folded thrust faults that were reported by Sabins (1957a). Furthermore, the thrust faults are believed to be more extensively offset by strike-slip faults than previously reported.

Locally these strike-slip faults are seen to predate the emplacement of stocks dated as $31 \mathrm{~m} . y$. old, and they probably were active late during the Cordilleran orogeny-perhaps in Paleocene time; regionally their movement history is complex. The amount of movement on the strike-slip faults probably was many kilometers. A left-lateral offset of $10-15 \mathrm{~km}$ is indicated by the disrupted trace of a thrust fault formed during the main phase of Cordilleran deformation.

In order to check the complex structural features of the Marble Canyon area in the northern Chiricahua Mountains, some $30 \mathrm{~km}^{2}$ of the Cochise Head quadrangle were mapped. The main part of this area is shown on plate 3. The blending of old (Sabins, 1957a) and new geologic maps was difficult east of Red Mountain, where additional remapping probably will lead to other changes.

Rocks of the Marble Canyon area comprise mainly a sequence of Paleozoic and Cretaceous carbonate and clastic rocks, which overlie a basement of Precambrian metamorphic and granitoid rock, and which are intruded by small bodies of porphyritic or granitoid rocks of Cretaceous or Tertiary age and of Oligocene age. Many of the rocks of the central part of the area are thermally, and perhaps also dynamically, metamorphosed. Descriptions and thicknesses of these rocks are admirably recorded by Sabins (1957a and 1957b) from nearby less deformed and unmetamorphosed areas; only a few comments on stratigraphy are added below.

The Pinal Schist of the basement rocks forms the southwestern wall of one stock of Precambrian granitoid rock to the northeast of the Apache Pass complex fault zone, and the northeastern wall of another such stock to the southwest of that fault zone. The facies represented by these separate masses of Pinal differ sufficiently that it seems likely that they were not deposited in their present sites but were brought together after deposition by movement along the fault zone. The Pinal to the northeast is a schistose to gneissic metavolcanic rock, whereas that to the southwest comprises one facies of metaquartzite and another facies of intertonguing metagraywacke, metavolcanic rock, and granular phyllite. The rocks to the northeast are cut by a few aplite dikes that strike regularly north to northeast; those to the southwest are intruded by many, variously oriented, meta-andesite and metadiorite dikelets, as well as by some aplite masses. Bedding in the rocks to the southwest is tightly folded, apparently mainly on east-west axes (although southwest-striking and plunging folds have also been reported), but folds are not well developed or are absent to the northeast. While one may suspect that 
a substantial amount of movement occurred to juxtapose such diverse kinds of Pinal Schist that have such different internal structures, the direction of movement is suggested only by structures other than those within the Pinal.

The Precambrian granitoid rock in the lower part of Marble Canyon, northeast of the Apache Pass complex fault zone, is light-gray, coarse-grained, sparsely but very coarsely porphysitic, massive quartz monzonite. A mode of one specimen shows the rock to have the following composition, in percent: quartz, 25.3; plagioclase (albite?), 29.5; orthoclase, 37.9; biotite, 7.0; titaniferous magnetite, 1.3; apatite, 0.2 ; sphene, 0.05 ; and zircon, a trace. The granitoid rock southwest of the fault zone was not examined within the area of plate 3 , but a few miles to the northwest it seems to be generally similar to or perhaps slightly more granodioritic than that within the area.

The basal formation of the Paleozoic sequence is referred to as the Upper Cambrian Coronado Sandstone, following the recommendation of Hayes (1972, p. B16). Its lithologic similarity with the Bolsa Quartzite has also led to the application of that name (Sabins, 1957a). Even without adequate local faunal studies, which are difficult to make because of widespread effects of low-grade metamorphism, the consensus is that the Coronado Sandstone here is the lithologic equivalent of the Bolsa Quartzite to the west and the Bliss Sandstone to the east, and is the time equivalent or lateral coarse-grained facies of the lower and middle parts of the Abrigo Formation to the west (pl. 1).

The Upper Cambrian and Lower Ordovician El Paso Dolomite overlies the basal formation; it is a thin- to moderately thick-bedded unit of limestone and dolomite that has some intercalated beds of siltstone or argillite. The base of the formation contains slightly more sandy beds, which at Apache Pass, $4 \mathrm{~km}$ to the northwest, contain Upper Cambrian trilobites, but these beds are sufficiently inconspicuous in weathering habit and lithology that they are not readily separated as a map unit equivalent to the upper part of the Abrigo, as is possible in the central Chiricahua Mountains.

The Portal Formation (Sabins, 1957b), of Late Devonian age, lies disconformably upon the El Paso Dolomite and consists of a fine-grained, thin-bedded, medium- to dark-gray carbonaceous limestone and abundant intercalated gray to pale-yellowish-brown argillite or metasiltstone. The upper part of the formation typically weathers into small slabs resembling a sandwich, in which a weakly resistant calcareous bed $1-2 \mathrm{~cm}$ thick separates two more strongly resistant hornfels beds of similar thickness.

In most places the Escabrosa Limestone is a lightgray to white, coarsely crystalline, thick-bedded to massive marble with relicts of large pods of chert and relicts of crinoid stems and horn corals. Apparently, with increasing metamorphism, the fossils and chert were obliterated and the rock lost its vestiges of gray color and of bedding. Where this alteration has progressed farthest, as in upper Marble Canyon, the rock even has been quarried for building stone. And where the metamorphism has been most intense, the contact between the Escabrosa and the overlying Horquilla Limestone was drawn beneath thin beds of conglomeratic phyllite and argillite near the base of the Horquilla. Typically, however, the Horquilla is fine grained and is thinner bedded than the Escabrosa; where metamorphism has not been pronounced, the Horquilla is light gray. The upper half of the Horquilla contains pale-yellowish-brown metasiltstone beds. Remnants of brachiopods and corals occur in many beds, the index fossil Chaetetes milliporaceous occurs near the middle of the formation, and fusulines occur in the middle and upper parts, as shown on plate 3 . The distribution of these faunal and lithologic features shows that the tops of the beds near the marble quarry persistently lie to the southwest. Aside from a few minor flexures, this sequence comprises homoclinal, northeastdipping overturned beds and not tight folds of large amplitude.

The highest formation of the sedimentary sequence is the Bisbee Formation of Early Cretaceous age, which appears in two facies that are separated, like those of the Pinal Schist, by the Apache Pass complex fault. The northeastern facies, which is metamorphosed, consists of siltstone, shale, intercalated beds of sandstone, and a few intercalated beds of conglomerate. The lowest three of these conglomerate beds in the Marble Canyon area were mapped by Sabins (1957a) as the basal Glance Conglomerate Member. Two of these three conglomerate beds are truncated along the base of the formation, presumably by a bedding fault of unknown size and uncertain genetic affinity, which is shown tentatively on structure section $A-A^{\prime}$ (pl. 3) as being a minor northeast branch of the Apache Pass fault. The southwestern facies, which is unmetamorphosed, consists of an upper unit of siltstone and intercalated sandstone and a thick conglomeratic and arkosic unit that occurs only in a separate fault-bounded block. This thick unit, which had previously been shown by Sabins (1957a) as a granitoid mass, is assigned here to the Glance Conglomerate Member, but conceivably could be of a 
younger formation. This juxtaposition of different facies of the Bisbee Formation also suggests that the movement along the Apache Pass complex fault zone was substantial.

The intrusive rocks of andesite, diorite, and quartz monzonite each show different geologic relations to the major faults, as indicated on plate 3 . The small diorite masses intruding the northeastern facies of the Bisbee Formation are mildly metamorphosed like their host rocks; the other diorite and andesite bodies are probably unmetamorphosed but are sufficiently hydrothermally altered to be unsuitable for radiometric dating. The stock and dikes of quartz monzonite, granodionite, aplite, and alaskite postdate the faulting of the area, and one stock is radiometrically dated at $31 \mathrm{~m} . \mathrm{y}$. The dated specimen has a mode, in percent, as follows: quartz, 28.1; oligoclase, 48.4; orthoclase (including a trace of residual(?) microcline), 15.3 ; biotite, 6.9 ; titaniferous magnetite, 0.9; apatite, 0.2 ; zircon, 0.1 ; and sphene, 0.05 .

The complex relations among the rock units at Marble Canyon were mainly caused by faulting, and locally also were produced by folding, intrusion, and metamorphism. The isoclinally folded thrust faults of Sabins (1957a), which prompted this reassessment, are here interpreted to be imbricate thrust slices. A symmetrical repetition of map units around the reported tight folds near the marble quarry is not recognized, although at the quarry there is some asymmetrical repetition due to thrust faulting that involves the Escabrosa and Horquilla Limestones. To the northwest of the quarry, the Escabrosa is gradually truncated from the west by a bedding fault and to the southeast it is abruptly faulted out by a transverse fault that may be a strike-slip fault. On the hills northwest of the quarry are several marker beds that form sinuous patterns on the map (pl. 3). As seen from near the quarry, these beds give the illusion of a fold, but they map out to be a generally steeply westward dipping homoclinal mass cropping out around a steep hill. Nevertheless, a scattering of atypical bedding attitudes does indicate that the Horquilla Limestone is cut by some small near-bedding-plane faults and is crumpled through local disharmonic folds. Aside from these minor folds, the Paleozoic and Cretaceous rocks northeast of the range crest and northeast of the Apache Pass complex fault dip northeast, overturned (or face southwest). The repetition of Paleozoic and Cretaceous rocks Sabins correctly interpreted as the result of a thrust fault, which in this study is called the Hidalgo thrust fault (Fort Bowie thrust fault of Sabins).
The Hidalgo thrust fault extends across the entire northern part of the Chiricahua Mountains, but it is offset in two places by younger movement on the Apache Pass complex fault and on the Emigrant fault, which splays off the complex fault just east of the area of plate 3 . As seen on the regional map (Drewes, 1980), the Hidalgo thrust fault extends from the Marble Canyon area southeastward to Emigrant Canyon, where it is offset left laterally about $3 \mathrm{~km}$, and thence continues southeastward to the Wood Mountain area, as recognized by Sabins. It also extends northwest of the Marble Canyon area to Apache Pass, where it is again offset left laterally, to Anderson Canyon, shown near the bottom of plate 3; and then northwestward to the edge of the Sulphur Springs Valley. Farther northwest of Apache Pass the regional map shows several fault-bounded blocks of Paleozoic rocks near the main fault; these slivers of Paleozoic rocks caught between the Cretaceous wall rocks also suggest strike-slip or multistage movement on the Apache Pass complex fault.

The offset of the Hidalgo thrust fault by the main strand of the Apache Pass complex fault is about 12 $\mathrm{km}$, which could be a maximum measure of the amount of strike-slip movement on the main strand. Without control on a possible vertical component of movement, the actual amount of movement cannot be given, but in any reasonable case it appears to be considerable. Thus, the inference of amount and kind of movement on the Apache Pass fault, derived from offset of the thrust fault, supports the inferences based on the stratigraphic evidence of juxtaposed diverse facies in both the Pinal Schist and Bisbee Formation.

The ages of the structural features in the Marble Canyon area show a sequence of events mainly attributable to the Cordilleran orogeny. During the Cretaceous and early Tertiary the following sequence of major events occurred: (1) deposition of the Bisbee during the late Early Cretaceous; (2) thrust faulting and some folding and tear faulting probably of latest Cretaceous or early Paleocene Age; (3) left-lateral strike-slip faulting probably during the late Paleocene or Eocene; and (4) intrusion of the quartz monzonite, metamorphism, and hydrothermal alteration in the Oligocene. The steeply plunging folds in the Pinal Schist of the Bowie Mountain area are probably of Precambrian age, because such deformation is not seen in the Paleozoic rocks. Conceivably the folds were formed as drag features during an ancient phase of strikeslip movement on the Apache Pass complex fault, for similar but smaller folds occur along other strike-slip faults. Evidence from a site a few kilometers to the southeast of the area shows that a segment of the 
Apache Pass fault was reactivated as a normal fault during or after the Miocene volcanism, less than 25 m.y. ago. Thus the Apache Pass complex fault appears to have been active at several times with diverse directions of movement, and apparently it is an ancient basement flaw.

\section{SOUTHERN DRAGOON MOUNTAINS}

Many of the rocks of the southern Dragoon Mountains, located $20-25 \mathrm{~km}$ northeast of Tombstone, like those of the northern part of the mountains, are shown by Gilluly (1956, figs. 5 and 11) at a scale of $1: 62,500$ and partly also at $1: 48,000$ to be complexly deformed. Despite Gilluly's creditable interpretation of most structural features, some of his interpretations were enigmatic. In particular, the lack of internal deformation of an extensive overturned mass of Bisbee Formation seemed puzzling to me; the nature, attitude, and transport direction of the major faults needed clarification, the reported thrusting of a Jurassic stock upon assorted Paleozoic rocks needed verification; and a peculiar dogleg in the zone of most complex structure at South Pass needed explanation. In addition, regional correlation of several igneous units might be tested through radiometric dating and, in one case, through petrographic study.

The review of the geology of the southern Dragoon Mountains entailed remapping an area of about 18 $\mathrm{km}^{2}$ at a scale of $1: 48,000$, with the assistance of $G$. $K$. Lee and C. H. Thorman. Additional effort was spent on reconnaissance north of the remapped area and on sampling the stock and some volcanic rocks nearby. The remapped area is shown on plate 4; where Gilluly's original work was incorporated on the edges of this map, the contact and unchecked units are marked with queries.

The remapped area straddles the southern part of the Dragoon Mountains from near South Pass to the vicinity of Turquoise Mountain in the northwest part of the Courtland mining district. The area is underlain by four diverse geologic terranes that are separated from each other by thrust faults and normal faults. The foothills and pediment to the northeast are underlain mainly by Cretaceous sedimentary rocks in a southwest-dipping homoclinal sequence. The crest of the range north of South Pass and the bold ridge east of South Pass (which is cut by the Canyon containing the abandoned mining camp of Barrett) are underlain by steeply inclined Paleozoic sedimentary rocks and Mesozoic sedimentary and igneous rocks. Jurassic quartz monzonite and granodiorite, together with their Precambrian schistose and granitoid host rocks, form a zone that underlies much of the foothills south of the aforementioned bold ridge east of the pass. Lastly, the lowest foothills west of South Pass are underlain by additional thrust faulted rocks, mainly of Paleozoic and Mesozoic age but including some of Precambrian age.

Inasmuch as most of the rocks of the area are well described by Gilluly (1956) and by Gilluly, Cooper, and Williams (1954), the general descriptions given previously in the regional stratigraphic summary will suffice for most formations. In the following paragraphs, additional descriptions are given of a few Jurassic and Cretaceous units that are of special concern to the reinterpretations. The study of the Jurassic stock was aimed specifically at making possible a mineralogical and chemical comparison to another stock outside this area. The Cretaceous sedimentary rocks are seen to include some of Late Cretaceous age, in addition to those of the Bisbee Formation of Early Cretaceous age. The Cretaceous volcanic rocks occur extensively along the ridge at Barrett, as well as at South Pass, and this study has shown that they contain exotic blocks of volcanotectonic origin rather than many small fault slivers.

The Gleeson stock is a large mass of granitic rock that underlies much of the southern part of the area of plate 4 and a contiguous area that extends another $10 \mathrm{~km}$ to the south. To the extensive observations made by Gilluly (1956, p. 55-60), only a few comments are added, based mainly on 23 modal descriptions. These descriptions are of samples taken at 1-2 km intervals along two north-south traverses of the outcrop area of the stock. The rock is typically light gray, coarse grained, and friable. As previously noted, it consists of a main phase and of a genetically related alaskitic or aplitic phase that is more resistant to weathering than the main phase, and so crops out mainly on the crest of the range and on knolls. Granodiorite is dominant over quartz monzonite, and rocks containing only biotite are far more common than those having both biotite and hornblende. Plagioclase is typically albite (An 0-5; albitized), and only one sample contains sodic andesine (An 30-35). Orthoclase is as common as microcline, which in many samples appears as relicts(?) of grid-twinned crystals. Alteration to chlorite, sericite, and clay minerals is widespread and, with the exception of one or two specimens, the biotite of the rock is recrystallized. This feature is particularly noteworthy because an extensive postJurassic source of heat from other stocks is not known in the area.

The Bisbee Formation crops out over much of the northeastern part of the area covered by plate 4 . The 
basal Glance Conglomerate Member is exposed only in a fault sliver west of Barrett Camp. Most of the formation comprises a sequence of clastic rocks equivalent to the Cintura and Morita Formations; the intervening Mural Limestone equivalent evidently has thinned out or has changed facies to such an extent that it is unmappable. As scaled from structure sections, this sequence is at least $1,500 \mathrm{~m}$ thick, but the continuity of the sequence remains undemonstrated, owing to the presence of many thick zones of poorly exposed siltstone and shale and of a thick rhyolite dike that parallels in strike both the adjacent beds and known faults along the main fidge of the mountains.

The main part of the Bisbee Formation is gray to reddish-gray siltstone and shale that contains intercalated light-gray sandstone units 1-3 m thick, making up about $10-20$ percent of the formation. The fine-grained beds are poorly exposed, but the sandstone units crop out in rows of low hills in the nearly flat terrain northeast of the thick rhyolite dike. Shale and siltstone units high in the Bisbee contain fragments of petrified wood, and others near the middle of the formation contain a few thin beds of lithographic limestone and zones of limy nodules. The upper half of each sandstone unit underlies the relatively broad, gently southwestward inclined dipslope sides of the low hills, and the lower half underlies the narrower, steeper northeast sides of the hills, where outcrops are relatively good.

The sandstone units in the Bisbee are crossbedded and graded bedded and have zones of small, rounded chert pebbles and grit near the base of each unit. Confusion arises with the crossbedding, however, for it consists of straight foreset beds inclined toward their bottomset and away from.their topset beds. Because of the particular combination of style of crossbedding and local relief, the lower half of each group of crossbeds, which mimics overturned beds, is most readily seen. The upper half, which can be found on the dip slopes, indicates that the crossbeds are of a kind not diagnostic of whether beds are right side up or overturned. The graded beds, however, are right side up. Similar observations were consistently made on traverses across the Bisbee Formation $5 \mathrm{~km}$ northwest of point $B^{\prime}$ of plate 4 (sections 26 and $27, T$. 18 S., R. 24 E.).

The next younger formation, presumably deposited disconformably upon the Bisbee, is thought to be the dacitic volcanic rock at South Pass. This formation and the younger latite tuff described below are bounded everywhere by faults. The dacitic rocks commonly are bluish-gray to pale-greenishgray flow breccias, and in places include some intrusive rocks and some vesicular, amygdular, and unbrecciated rocks. Small phenocrysts are of plagioclase and in places also of hornblende, but the rock is so strongly altered that little of its petrogi:uphy is known. The rock is called dacitic rather than andesitic because it resembles other betterknown formations of that composition in the region. The dacitic rocks have been correlated with the lower memberz of the Salero Formation and with the Silver Bell Formation (Wood, 1959), both of Late Cretaceous age, of the Santa Rita and Tucson Mountains and elsewhere (Drewes, 1972b). However, they may be found to correlate more closely with other dacitic rocks in southwestern New Mexico, which are slightly younger.

In places, moderately to strongly indurated, welded latitic tuff appears to overlie the dacitic rocks on a depositional contact. The tuff contains sparse crystals of quartz, feldspar, altered biotite, and abundant secondary minerals. Many blocks of Escabrosa and Horquilla Limestones and of Epitaph Dolomite are contained in the latitic tuff near Barrett Camp and in the upper(?) third of the main body of tuff near South Pass. Many larger blocks, shown on plate 4 , are a few tens of meters long, and some are about $100 \mathrm{~m}$ long. Many more blocks are too small to be mapped. Subtabular blocks are common among the larger ones, and these are alined nearly parallel to the bedding(?) and to adjacent thrust faults. Shear zones were not seen adjacent to the large blocks or between alined large blocks. The inclusions are believed to have been incorporated into the tuff by volcanotectonic or sedimentary processes rather than by a purely tectonic one. In hand specimen the latite tuff resembles the Sugarloaf Quartz Latite, found $8 \mathrm{~km}$ to the southeast, as noted by Gilluly $(1956$, p. 69$)$. The latite tuff also is probably correlative with the rhyodacite member of the Salero Formation (Drewes, 1972b) and possibly with part of the Uncle Sam Porphyry west of Tombstone. All of these formations contain exotic blocks emplaced by volcanotectonic processes; only the size of the exotic blocks varies from formation to formation.

The youngest Cretaceous formation consists of olive-brown to reddish-brown siltstone, sandstone, and conglomerate lying between the volcanic formations and the large rhyolite dike. Gilluly (1956, p. 68) recognized the problems of identifying this formation and its stratigraphic position. Conglomerate is fairly abundant and the clasts are typically subangular coarse pebbles and cobbles derived from a variety of sources, including dacitic and latitic volcanic rocks, Paleozoic limestone and 
quartzite, and Bisbee siltstone and sandstone. A few small rounded chert pebbles in the conglomerate are probably recycled from the conglomeratic sandstone of the Bisbee. This sedimentary formation is here tentatively correlated with the upper member of the Salero Formation, on the premise that the volcanic fragments were derived from the known Upper Cretaceous volcanic rocks of the area. Alternatively, the formation may be as old as the Fort Crittenden Formation, thereby requiring that the known volcanic rocks, or other unknown but nearby ones, are of early Late Cretaceous age. In either case the formation is younger than the Bisbee, and is probably of Late Cretaceous age.

The dominant structural feature of the area is a zone of thrust faults referred to by Gilluly as the Dragoon thrust fault, and here recognized to be part of the regional structure called the Cochise thrust fault. I concur with Gilluly in placing the fault along the east side of the main ridge north of South Pass and along the north side of the ridge at Barrett. However, southeast of the map area of plate 4 , as shown on the regional map (Drewes, 1980), the main or lower strand of the Cochise thrust fault lies at least farther east than Turquoise Mountain, and perhaps entirely east of the outcrop area at Courtland. An upper strand of the Cochise thrust fault that begins near South Pass follows subparallel to the main strand and may be the fault west of Turquoise Mountain (Gilluly showed two faults west of the mountains, which I have not tried to verify and for simplicity do not show in the southeast corner of plate 4). In essence, the Cochise thrust fault separates underlying Cretaceous formations from overlying older formations-Jurassic to Precambrian. It dips variously westward and southward, steeper to the west and flatter to the east. Several drill holes have penetrated the upper strand of the Cochise thrust, and one of them appears to have reached the rocks beneath the lower or main strand.

Another large thrust fault, inferred to be an extension of the Fourr Canyon thrust fault of the northern Dragoon Mountains, lies in the lowest foothills west of South Pass. Much as was shown by Gilluly, it separates an overlying plate of Paleozoic and Mesozoic formations from Precambrian rocks, and it dips gently to the west.

Smaller structural features are abundant near the larger ones, and some of these remain enigmatic, suggesting a polyphased history of development. The Cochise thrust fault, for instance, is disrupted by north- and northeast-trending steep faults that clearly postdate the thrust faulting. Elsewhere, marked changes occur across these steep faults, such as the change from a thick mass of volcanics near South Pass to a lenticular, much thinner sheet farther east of the pass. Such changes suggest some pre-thrust-fault movement on a few faults. The fact that similar sequences of lower Paleozoic rocks occur in similar upended positions north of South Pass and at Turquoise Mountain suggests an erstwhile continuity of these masses, with a separation perhaps brought about by a tear fault in the rocks between the Cochise and Fourr Canyon thrust faults; if such a tear fault existed, it did not extend into the adjacent plates. Resolution of these problems requires further detailed mapping beyond the edges of the map of plate 4.

The close spatial association of the Cretaceous volcanic rocks that contain exotic blocks with a major thrust fault suggests one aspect of the genesis of the extraordinarily complex structure that Gilluly (1956, pl. 11 and other plates) painstakingly mapped in the Courtland-Gleeson area. The close association of these volcanics with thrust faults extends south from Turquoise Mountain beyond the area of plate 4 to Sugarloaf Hill near Gleeson. On the west side of the Santa Rita Mountains, a tectonic jumble that is less complex than that in the Courtland-Gleeson area was explained by Drewes (1972a) as being formed by the close association of faulting and a high-energy volcanism. Perhaps here, too, volcanism and thrust faulting occurred together, with the result that some blocks of Bisbee Formation and older formations are inclusions in an igneous host, and others are fault blocks. Conceivably, some may even be faulted masses of exotic-block volcanic material. Note that west of the Dragoon Mountains, thrust faults are commonly older than the 72 m.y.-old exoticblock-bearing rhyodacite; here they are younger.

In summary, the southern part of the Dragoon Mountains is seen to be underlain by complexly deformed rocks, as was previously known, but a few significant modifications of previous interpretations are proposed. The thick sequence of Cretaceous rocks beneath the Cochise thrust fault is right side up, rather than overturned. On the basis of regional considerations, I concur with Gilluly that this sequence is probably underlain at unknown depth by another thrust fault. The structural enigma presented by steeply dipping thrust faults at South Pass that change their strike abruptly suggests the combined effect of perhaps three episodes of faulting: pre-Cordilleran faulting, Cordilleran thrust and tear faulting, and post-Cordilleran normal faulting. The intense structural jumble in the Courtland-Gleeson area may be caused by a combination of purely tectonic events and a volcanotectonic event. 
SOUTHERN SWISSHELM MOUNTAINS AND SOME ADJACENT AREAS

A southwestward-overturned major fold that is reported in the southern part of the Swisshelm Mountains by Epis (1956) has been reinterpreted through field study by P.T.Hayes and me to be a homoclinally northeastward-dipping, unfolded but much faulted sequence. The Paleozoic rocks do overlie Cretaceous rocks along a thrust fault, as shown by Epis and compiled by Cooper (1959), but that fault is less extensive than they show; its southeastern end, rather than being a thrust fault, is better interpreted as a complex structure with leftlateral(?) strike-slip movement, which also has a reverse component of movement (pl. 5). From the area of plate 5 , geologic mapping was extended northward (fig. 7), where evidence was found to identify another major thrust fault, and eastward (fig. 8), where a granitic intrusive rock was found that probably postdates, rather than predates, still other thrust faults.

The reported major fold lies between Leslie Canyon and Castle Dome (pl. 5), located about $25 \mathrm{~km}$ north of Douglas, Ariz. The key formations of this area are the Upper Devonian Swisshelm Formation of Epis, Gilbert and Langenheim (1957) (or Martin Formation of some geologists), the Mississippian Escabrosa Limestone, and the Pennsylvanian Horquilla Limestone. Only the few lithologic features of concern to the new interpretation are reported here; and detailed descriptions by Epis (1956 and 1958), Epis and Gilbert (1957), and by Epis, Gilbert, and Langenheim (1957) provide more complete lithologic accounts of the rocks.

The Swisshelm Formation is a mixture of thinbedded gray limestone, brown dolomite, quartzite, quartz sandstone, shale, and marlstone. As a whole, the formation underlies a low terrain between a high ridge of limestone to the west and another ridge capped by either limestone or rhyolite volcanic rocks to the east; however, because of its varied lithology, the low terrain contains many small but bold topographic features. Through the mapping of some of the subdivisions of the Swisshelm Formation (marker horizons $q$ and $\bar{d}$ on pl. 5), the structural complexities of the lowland belt are shown; not only are the marker horizons offset in many places, but also the beds of the separate structural blocks dip in various directions and amounts. Some of these subtle faults are marked by alined pods of silicified rock. As a whole, however, the dips are moderately steep to the northeast, rather than symmetrically opposed to each other on opposite sides of a possible fold axis.
Very likely additional smaller faults will be identified, particularly along bedding planes in weak lithologies, through more meticulous mapping. Under these circumstances, the stratigraphic sections measured in this area without benefit of detailed mapping (Epis, Gilbert, and Langenheim, 1957) are of restricted value.

The Escabrosa Limestone is a medium-gray, thickbedded, bioclastic to crinoidal limestone that contains scattered bun-shaped, dark-gray chert nodules. It typically underlies steep slopes and cliffs, but near Castle Dome it underlies some fairly gentle hills. The main body of this limestone underlies a wedge-shaped area west of Castle Dome, and not a continuous belt between the Swisshelm Formation and the Horquilla Limestone extending from Castle Dome across Leslie Canyon, as previously mapped.

The Horquilla Limestone is a light- to mediumgray, thin-bedded, fine-grained, bioclastic limestone that contains thin, lenticular beds and small nodules of light-pinkish-gray chert. That part of the formation overlying marker horizon $\mathrm{c}$ on plate 5 , however, is moderately thin bedded and moderately coarse grained. The upper part of the formation contains some intercalated pinkish-gray siltstone beds. Although slopes underlain by most of the formation characteristically are ledgy, the thickbedded unit underlies a band of cliffs sufficiently conspicuous to be mistaken at a distance for the Escabrosa Limestone. Lithologic details and the presence of fusulines within and beneath the thickbedded unit of the Horquilla, however, indicate its younger age, for these fossils are not present in Mississippian rocks. Instead of being a strongly overturned limb of a major fold, these rocks are also right side up and are homoclinally northeastward dipping.

Faults separate the Swisshelm, Escabrosa, and Horquilla from each other and from the altered dacitic volcanic rocks of Cretaceous(?) and Tertiary(?) age that underlie the lowlands in the southern and western parts of the area of the map (pl. 5). The entire length of the contact between the Paleozoic rocks and the volcanic rocks was viewed by Epis to be a thrust fault, but Hayes and I feel that only the northwestern part is largely a thrust fault; the other parts are different types of faults. Much of the fault between the Horquilla Limestone and the dacitic volcanic rocks northwest of Castle Dome dips $40^{\circ}-45^{\circ}$ northeast, subparallel to the bedding in the overlying limestone. In places, low-angle faults splay off the thrust fault and extend into the overlying plate. A few high-angle faults either cut the underlying rocks and are cut by the thrust fault, 
or cut the overlying rocks and abut the thrust fault. Most high-angle faults, however, offset the thrust fault, and these commonly trend northerly. Small disharmonic folds and faults are scattered at wide intervals within the Horquilla Limestone, and the anomalously steep or locally overturned beds that do occur are found near these features. Although most of the rock underlying the thrust fault is the dacitic volcanic formation, which may be generally correlative with rocks of Sugarloaf Hill and South Pass in the southern Dragoon Mountains, some of the rock is rhyolite tuff and conglomerate of midTertiary age in three small areas. These Tertiary rocks appear to have been affected by at least a little late movement along the thrust fault.

The faults that separate the Swisshelm, Escabrosa, and Horquilla trend northwest; many other associated faults appear to form two sets, one trending nearly north, the other northwest. The sets of faults are represented only by a single fault strand along the lower reaches of Leslie Canyon, where the strand is labeled the Leslie Canyon fault (pl.5). Near Castle Dome to the southeast, the single fault splays into a zone of faults more than $1 \mathrm{~km}$ wide. On the map the bounding faults of this zone are identified as the southwest and northeast branches of the Leslie Canyon fault zone. West of Castle Dome the southwest branch of the fault zone offsets the trace of the thrust fault, and northwest of the dome another splay fault also offsets the trace of the thrust fault, thereby indicating that major movement on the thrust fault is older than major movement on the Leslie Canyon fault system.

Additional data about thrust faults were obtained in an area a few miles north of Leslie Canyon and removed from the supposed major fold (fig. 7). Two thrust faults on the west side of the range each emplace Pennsylvanian rocks on the Lower Cretaceous Bisbee Formation. The upper of these faults, which was shown by Cooper (1959) to die out within the Horquilla Limestone, is now seen to extend first southward as a bedding-plane fault, and then eastward along the lower part of Leslie Canyon (pl. 5) and across the range, where it truncates several Paleozoic formations. The lower of these faults may be correlative with the thrust fault northwest of Castle Dome, in which case the change in lower-plate rock, from the Glance Conglomerate Member of the Bisbee Formation to the north to dacite volcanic rocks to the south, may be due to prethrust movement on the Leslie Canyon fault.

On the east side of the range, in the area of figure 7, other thrust faults are shown by Cooper (1959) to truncate a quartz monzonite or granodiorite dike.
The contact relations between the dike and the thrust fault, while equivocal in some places, suggest in others that the dike cuts or abuts the thrust faults, rather than being cut by the thrust faults. If this relation is correct, a radiometric date of the dike would therefore supply a minimum age, rather than a maximum age, of the faulting; perhaps elsewhere in the range, where the field relations are clearer, such data could be obtained.

The new evidence just reviewed indicates that both the thrust faults and the Leslie Canyon fault system were active during the Late Cretaceous or early Tertiary, and that during this time a major phase of movement on the Leslie Canyon fault system occurred after major movement on the thrust faults. Weaker evidence and inference further suggest that both fault systems were active at least twice. A little movement probably took place along a segment of one thrust fault during or after the mid-Tertiary, and movement may have taken place along the Leslie Canyon fault in pre-thrust time.

The direction of movement on the faults is inadequately established; shear features were not found on the fault planes, nor were drag features found near them. The upper thrust plates possibly moved northeastward, judged from very scanty data provided by the disharmonic minor folds and the overturned beds associated with such folds within the Horquilla Limestone. The minor mid-Tertiary or younger movement may have been to the south or west, but this opinion is based essentially on my feeling that it is unlikely that the small masses of mid-Tertiary rocks along the fault were overthrust by a far-moving plate of Paleozoic rocks. Perhaps this late movement was a minor shifting of rock away from the late Oligocene and early Miocene igneous center of the Chiricahua Mountains.

The northeast branch of the Leslie Canyon fault extends southeast of the area of the fold reported by Epis, Gilbert, and Langenheim (1957) and ultimately extends beyond the southeastern end of the Swisshelm Mountains and across the Pedregosa Mountains (fig. 8). Toward the southeastern end of the Swisshelm Mountains (pl. 5 and fig. 8), the northward dip of the fault gradually steepens from $60^{\circ}$ to $85^{\circ}$. In that area, rock types not present in the immediately adjacent wall rocks occur in small fault slivers along the structure. There, too, some segments of the fault are intruded by rhyolite dikes, and rocks along other segments of the fault are silicified. In the Pedregosa Mountains (fig. 8), basalt dikes of Quaternary and Tertiary age intrude parts of the fault.

The movement on the Leslie Canyon fault system 

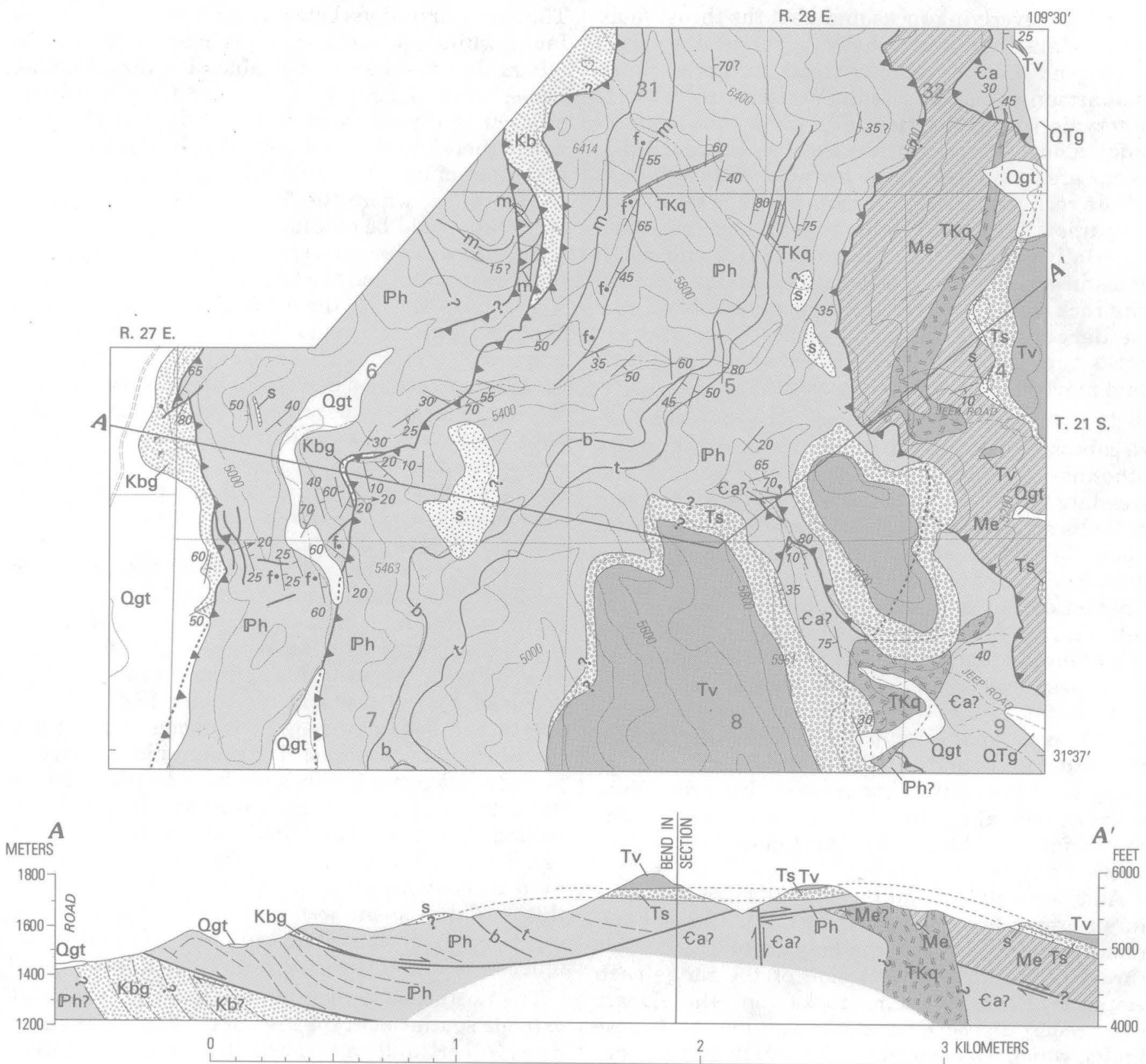

FIGURE 7 (above and right)._Geologic map and structure section of part of the central Swisshelm Mountains. Geology by Drewes, 1969 and 1972, assisted by A. J. Toevs, 1969, and G. K. Lee, 1972. Base from U.S. Geological Survey, 1:62,500, Swisshelm Mountain (1958); contour interval $40 \mathrm{ft}$. (Figure scale approximately 1:21,000.)

was probably a combination of reverse and leftlateral motion. The juxtaposition of Paleozoic rocks in the hanging wall with Cretaceous or Tertiary rocks in the footwall suggests a component of reverse movement in the area east of Castle Dome. The pattern of splay faults northwest of the dome and the slivers of rock caught along the fault east of the dome suggest the fault also had strike-slip movement. The geometry and movement history of this fault system suggest that it may be one of the set of northwest- trending complex faults of the region.

In summary, the geologic review of the field relations of deformed rocks in the southern part of the Swisshelm Mountains and some adjacent areas shows that there is no major southwest-overturned fold and consequently no basis for postulating massive, southwestward-directed thrust faulting. The review also indicates the need for caution in accepting the data of published stratigraphic sections of this area. And finally, it demonstrates that the rocks 
CORRELATION AND DESCRIPTION OF MAP UNITS

\begin{tabular}{|c|c|}
\hline Qgt & GRAVEL (QUATERNARY)—Alluvium in fans \\
\hline QTg & 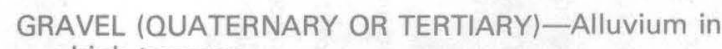 \\
\hline TV & OLCANIC ROCKS (TERTIARY)-Mainly \\
\hline & $\begin{array}{l}\text { welded tuff; may include some indurated tuff and } \\
\text { lava flows }\end{array}$ \\
\hline sits & SEDIMENTARY ROCKS AND TUFF (TERTIARY)- \\
\hline & $\begin{array}{l}\text { Conglomerate, tuffaceous sandstone, and weakly } \\
\text { indurated rhyolite tuff }\end{array}$ \\
\hline TKa & QUARTZ MONZONITE AND GRANODIORITE (CRE- \\
\hline & $\begin{array}{l}\text { RY)-Stocks and dikes. } \\
\text { of aplite }\end{array}$ \\
\hline & nomot \\
\hline $\mathrm{Kb}$ & ne-Reddish-gray siltstone, \\
\hline $\mathrm{Kbg}$ & Conglomerate Member-Limestone pebble \\
\hline & nglomerate, and some interca- \\
\hline $\mathbb{P h}$ & STONE IUPPER AND MIDDLE \\
\hline & $\begin{array}{l}\text { bray, fine- to medium-grained, thin- to medium- } \\
\text { units have intercalated units of pale-brownish-gray } \\
\text { to reddish-gray siltstone }\end{array}$ \\
\hline & Marker horizon at top of gray ledgy limestone unit \\
\hline & Marker \\
\hline & Marke \\
\hline & Beds containing abundant fusulin \\
\hline Me. & $\begin{array}{l}\text { ESCABROSA LIMESTONE (MISSISSIPPIAN)- } \\
\text { Medium-gray coarse-grained, bioclastic to crinoi- } \\
\text { dal, thick-bedded, cherty limestone }\end{array}$ \\
\hline$€ a$ & ABRIGO FORMATION IUPPER AND MIDDLE \\
\hline & $\begin{array}{l}\text { and thin-bedded limestone. May include you } \\
\text { rocks }\end{array}$ \\
\hline s & SILICIFIED ROCK \\
\hline & CONTACT_Dotted where concealed \\
\hline . & NORMAL FAULT-Bar and ball on downthrown side \\
\hline 120 & $\begin{array}{l}\text { THRUST FAULT-Showing dip. Dotted where con- } \\
\text { cealed; queried where basis for projection is lack- } \\
\text { ing. Sawteeth on upper plate }\end{array}$ \\
\hline$\leftrightharpoons$ & $\begin{array}{l}\text { FAULT ON CROSS SECTION-Arrow couple shows } \\
\text { relative movement }\end{array}$ \\
\hline & $\begin{array}{l}\text { STRIKE AND DIP OF BEDS } \\
\text { Inclined }\end{array}$ \\
\hline & \\
\hline
\end{tabular}

were cut by at least two types of major faults, each with a history of possible multiple movement, and each with a phase of major movement during the time span covered by the Cordilleran orogeny. The local structural history and style of deformation thus support the synthesis developed regionally.

\section{REINTERPRETATIONS OF UNCONFORMITIES AND FAULTS}

In regions like southeastern Arizona, where at least some scattered signs of bedding-plane faults are recognized, the field determination of the nature of geologic contacts between units of markedly diverse structural strength inevitably is difficult. Consequently, interpretations of contact conditions are likely to remain controversial for a long time. Such difficulties are to be expected because, while other kinds of faults are commonly associated with missing strata or truncated beds, evidence of movement may be subtle or undetectable along some segments of a bedding-plane fault. The following field examples illustrate some kinds of subtle evidence and explain my belief that bedding-plane faults are more widespread in southeastern Arizona than generally supposed. Strictly viewed, however, this evidence only supports the notion that, where other sorts of deformation are abundant, all contacts of marked lithologic contrast should be examined with care; if they prove to be faulted, the evidence indicates nothing about the magnitude of that faulting. On the other hand, a local lack of evidence of subtle faulting does not eliminate the possibility that faulting has nevertheless occurred; demonstration of the absence of bedding-plane faulting requires persistent lack of evidence over a substantial area.

A case in point is the central part of the Dragoon Mountains, just south of Middlemarch Pass. Keith and Barrett (1976) conducted a local study in this area and reported no bedding-plane faults along key contacts, whereas Gilluly (1956) and Drewes (1980) projected such faults through the area because of evidence found over a more extensive region. A similar case is the northern part of the Santa Rita Mountains, where Creasey and Quick (1955) reported no faulting along the base of the Bolsa Quartzite and other contacts, as determined from local mapping, but Drewes (1971a and 1972a) found regional evidence in support of bedding-plane faults.

New detailed mapping of parts of the central Dragoon Mountains, Tombstone Hills, and northern Whetstone Mountains illustrates the kinds of evidence used to support interpretations of subtle bedding-plane faults.

\section{CENTRAL DRAGOON MOUNTAINS}

An unexposed bedding-plane fault is inferred to follow the basal contact of the Bolsa Quartzite in some low hills by Grapevine Canyon on the east flank of the central Dragoon Mountains (fig. 9), and about $8 \mathrm{~km}$ northwest of Pearce. The identity and distribution of formations shown on this map is in accord with that shown by Gilluly (1956, pl. 5). Both maps show that the southwest flanks of the hills are underlain by Pinal Schist, the crest of the hills and much of their northeast flanks by Bolsa Quartzite, and the lowest parts of the northeast flanks by the 


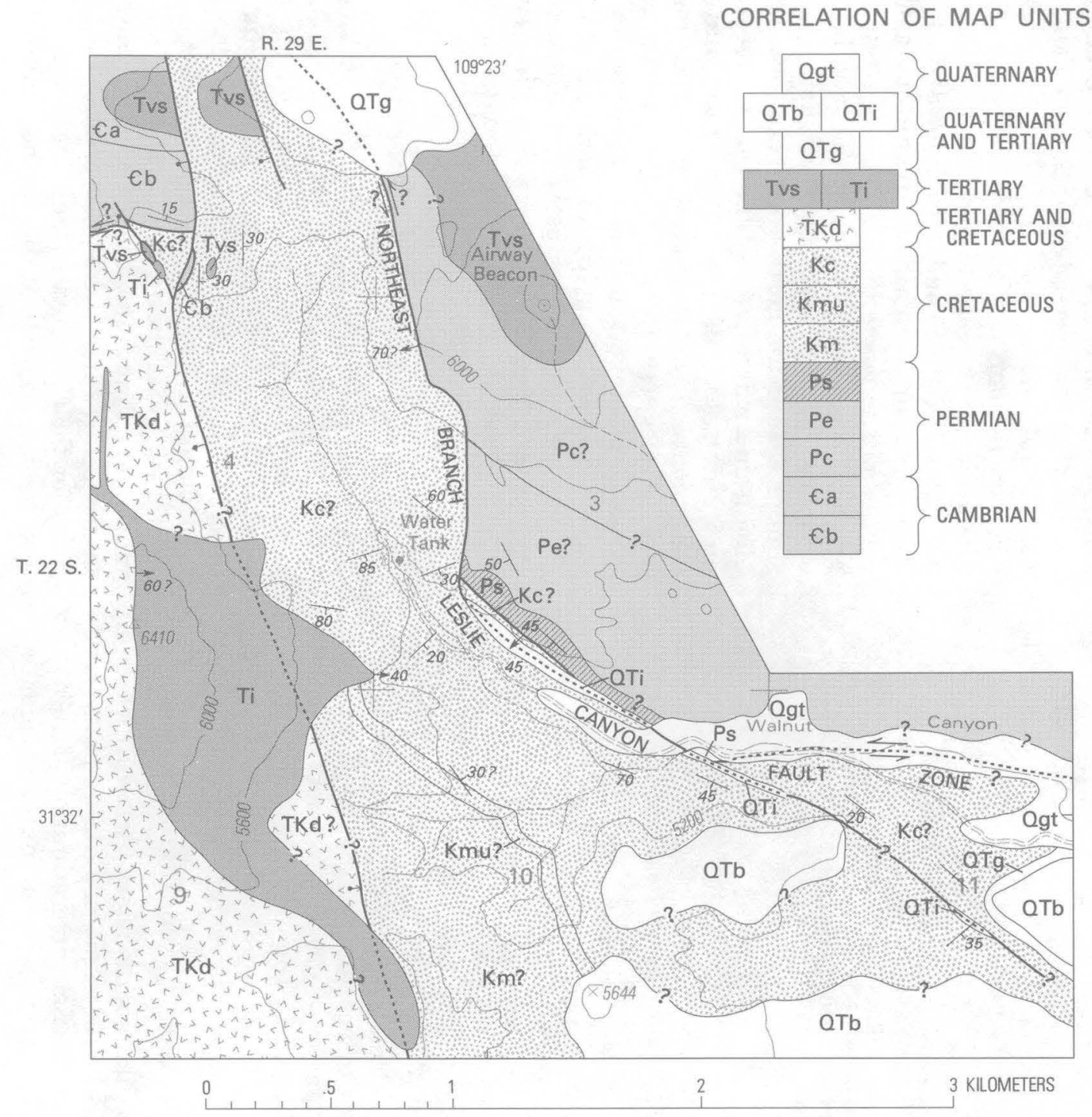

\section{DESCRIPTION OF MAP UNITS}

Qgt GRAVEL (QUATERNARY)—Alluvium on terraces BASALT (OUATERNARY AND TERTIARY): Lava flows

Dike

GRAVEL (QUATERNARY AND TERTIARY) Includes gravel possibly younger than basalt VOLCANIC AND SEDIMENTARY ROCKS (TERTIARY)-Rhyolite tuff and tuffaceous sandstone and conglomerate

Ti INTRUSIVE ROCK (TERTIARY)-Rhyolite porphyry plug and dike

TKA 2 DACITIC VOLCANIC ROCKS (TERTIARY AND CRETACEOUS)-Flow breccia and intercalated sedimentary rocks

BISBEE GROUP (LOWER CRETACEOUS):

KC. Cintura Formation-Siltstone, sandstone, and some intercalated conglomerate

Kmu Mural Limestone-Light-medium-gray, finegrained, fossiliferous limestone and intercalated siltstone

$\mathrm{Km}$ Morita Formation-Siltstone and sandstone NACO GROUP (LOWER PERMIAN)

is Scherrer Formation-Light-gray fine-grained quartzite and limestone

$\mathrm{Pe} \quad$ Epitaph Dolomite-Gray dolomite and red shale and sandstone

Colina Limestone-Medium-gray limestone

Ca ABRIGO FORMATION (UPPER AND MIDDLE CAMBRIAN)-Shale, sandstone, and thinbedded limestone

$\mathrm{Cb}$ BOLSA QUARTZITE (MIDDLE CAMBRIAN) - Thickbedded, coarse-grained quartzite and sandstone

60
1 CONTACT-Showing dip. Queried where uncertain

451 - FAULT-Showing dip. Dotted where concealed or intruded. Queried where uncertain. Bar and ball on downthrown side. Arrow couple shows relative movement

STRIKE AND DIP OF BEDS

$\frac{45}{1} \quad$ Inclined

FIGURE 8.-Geologic map of the southeastern end of the Swisshelm Mountains and part of the Pedregosa Mountains along Walnut Canyon. Geology by Drewes, 1972, assisted by G. K. Lee. Base from U.S. Geological Survey, 1:62,500, Pedregosa Mountains (1958); contour interval $80 \mathrm{ft}$. (Figure scale approximately 1:30,000.) 

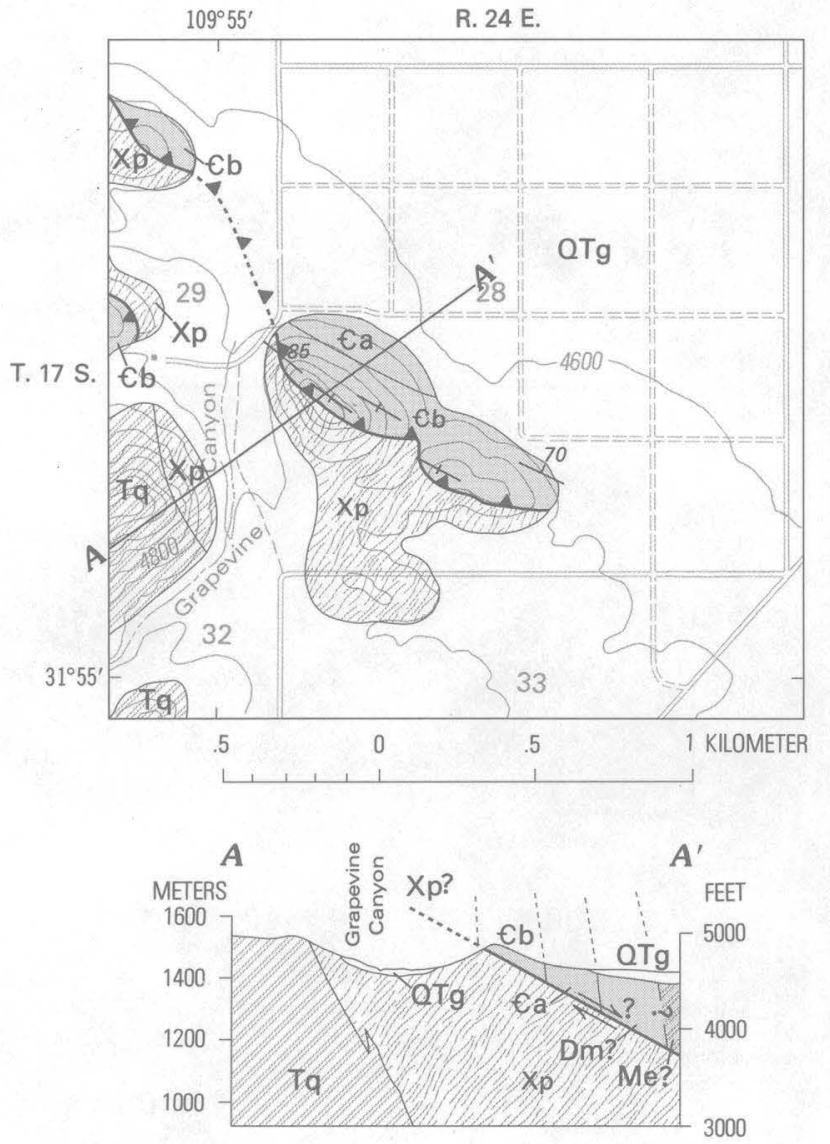

CORRELATION AND DESCRIPTION OF MAP UNITS

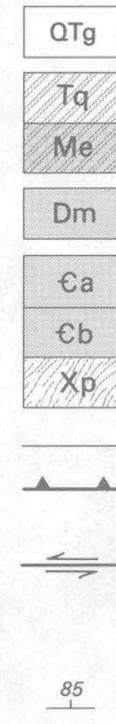

GRAVEL AND SAND (QUATERNARY AND TERTIARY)

QUARTZ MONZONITE (TERTIARY)

ESCABROSA LIMESTONE (MISSISSIPPIAN)Shown only on section

MARTIN FORMATION (DEVONIAN)-Shown only on section

ABRIGO FORMATION (CAMBRIAN)

BOLSA QUARTZITE (CAMBRIAN)

PINAL SCHIST (PRECAMBRIAN X)

CONTACT

THRUST FAULT-Dotted where concealed. Sawteeth on upper plate

FAULT ON CROSS SECTION-Arrow couple shows relative movement. Queried where basis for projection is lacking

STRIKE AND DIP OF BEDS:

Inclined

Vertical

FIGURE 9.-Geologic map and structure section of part of the central Dragoon Mountains near Grapevine Canyon. Geology by Drewes, 1974. Base from U.S. Geological Survey, 1:62,500, Pearce (1958); contour interval $40 \mathrm{ft}$. (Figure scale 1:31,680.)

Abrigo Formation. This sequence of Precambrian and Cambrian rocks is in normal order, and both contacts and bedding attitudes are shown to dip east by deflections of contacts around hills and by the sparse map symbols. The basal contact of the quartzite is concealed by talus and colluvium, and, inasmuch as conglomerate stringers are found low in the quartzite, the sequence had previously been judged to be unbroken and the contact simply an unconformity.

However, closer scrutiny, prompted by structural considerations of neighboring areas, yielded two additional bits of vital data that throw some doubt on the earlier interpretation. First, the position of the contact was more precisely mapped on an improved topographic base (Pearce, Ariz. 15-minute quadrangle) using the clues provided by the distribution of schist fragments in the colluvium. By application of the three-point method to these data, it was estimated that the contact dips $40^{\circ}$ northeast. Second, more attitudes were measured in the quartzite near the contact, and the beds were found to dip $70-90^{\circ}$ northeast. Pebble layers occur in nearby sections of Bolsa Quartzite, not only at the base of the formation, but also throughout the lower third of it; thus the occurrence of a conglomerate bed at the base need not mean that it is the basal conglomerate of the formation. While a local angular discordance in which the overlying beds abut the contact could occur against a hill on the sub-Bolsa surface, neither the regional stratigraphic record nor the local lithologic record provide support of this possibility. Therefore, the basal contact of the Bolsa Quartzite is inferred to be a bedding-plane fault. Accordingly, the thickness of the Bolsa that may have been sheared out is unknown. Likewise, the amount of movement of the fault is unknown, but I doubt that a minor adjustment in response to the tilting of the rocks would account for the amount of the angular discordance that is present. This fault may be an important thrust fault, depending, of course, on the structural evidence in adjacent areas. 


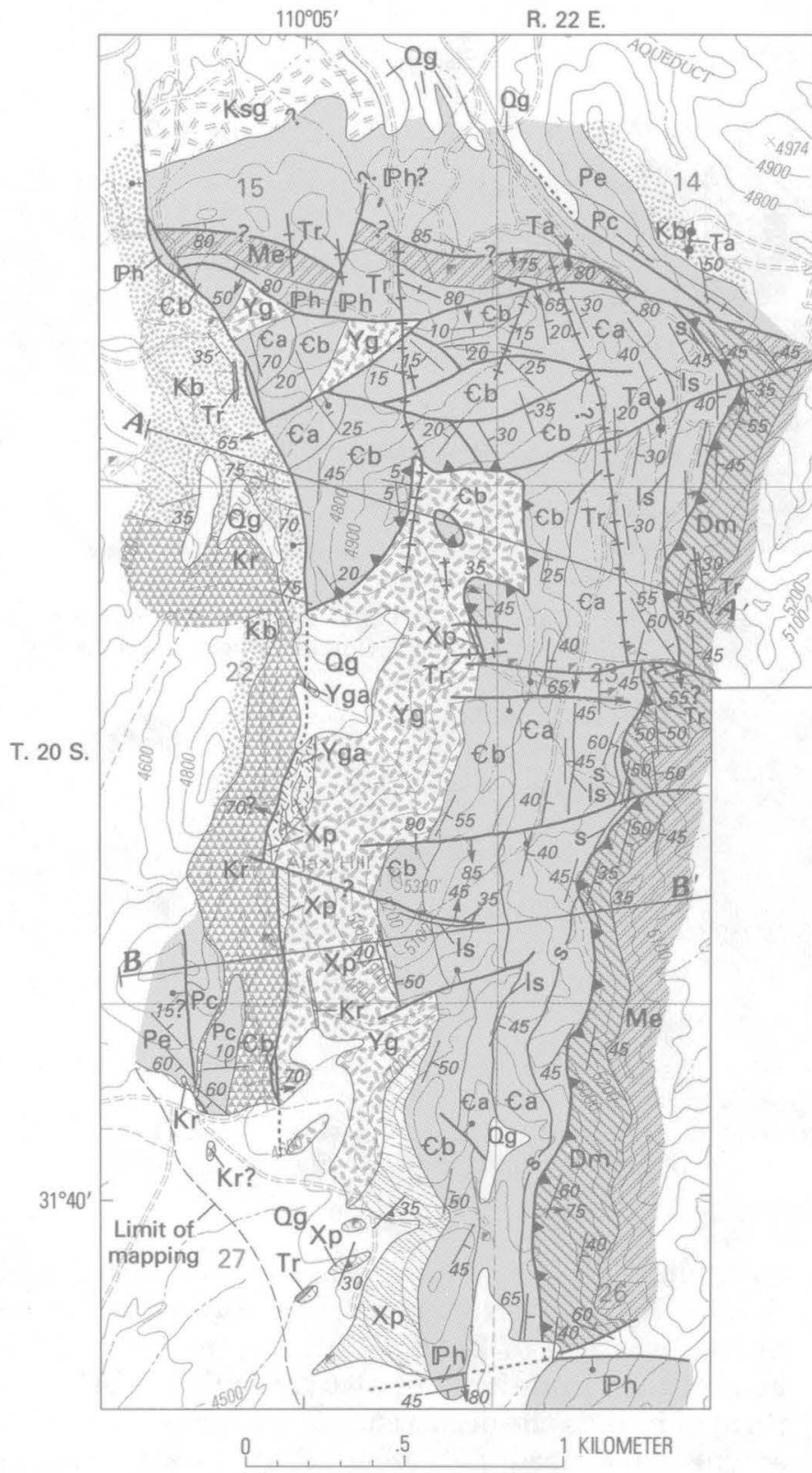

TOMBSTONE HILLS

Previously unmapped bedding-plane faults occur within and beneath the Paleozoic rocks of the Tombstone Hills. From a restudy of a small area (fig. 10) 3-4 km southwest of Tombstone, C. H. Thorman and I agree with Gilluly (1956, pl. 5) on the
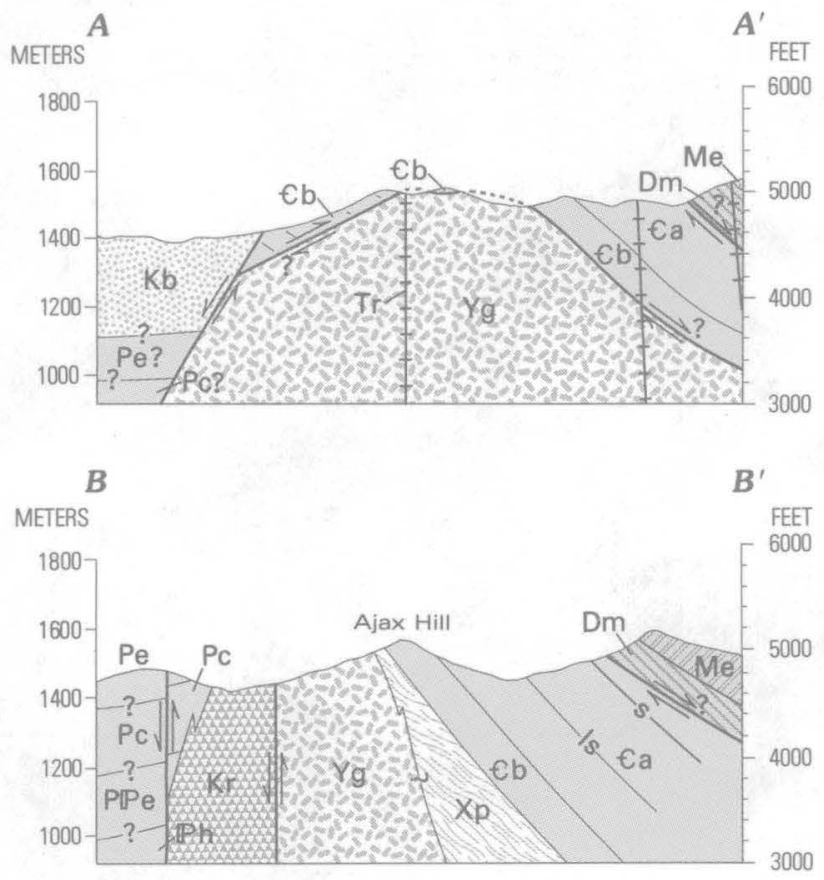

CORRELATION OF MAP UNITS

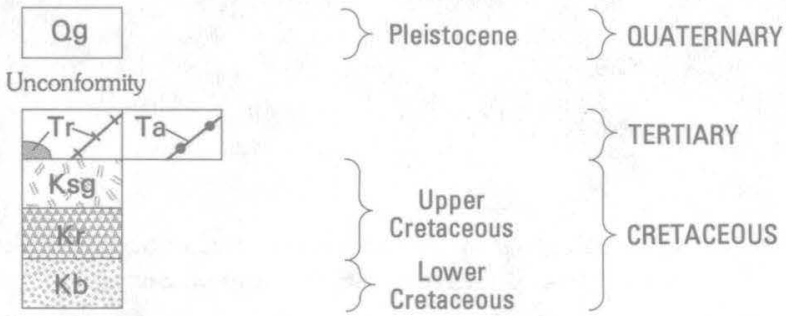

Unconformity

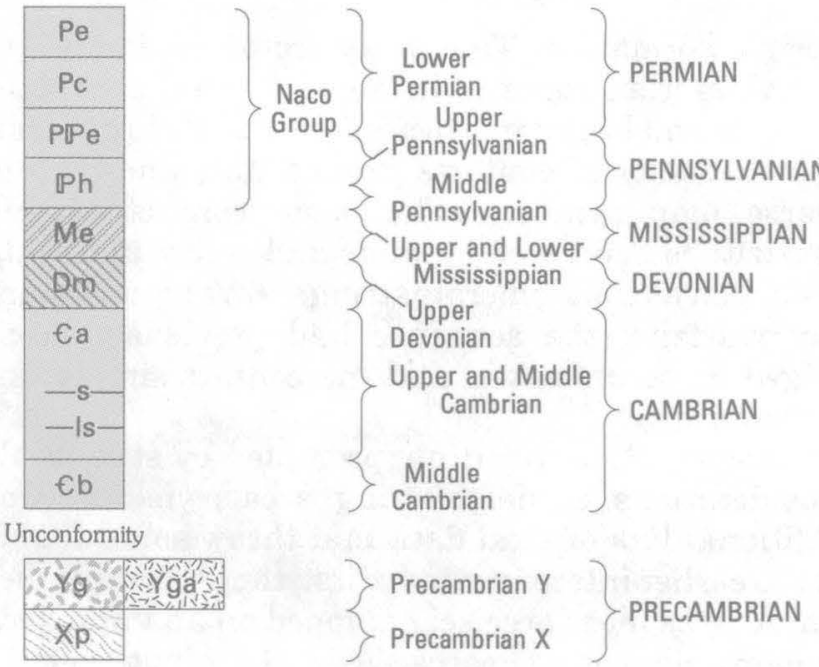

identification and general distribution of major map units, but we disagree with Gilluly on the nature of some of the contacts.

In essence, the area comprises three main structural blocks separated by high-angle faults. Two eastern blocks are separated from each other by 


\section{DESCRIPTION OF MAP UNITS}

\begin{tabular}{|c|c|}
\hline Qg & GRAVEL (PLEISTOCENE)-Alluvium on terraces \\
\hline & RHYOLITE (TERTIARY)—Sparsely porphyritic \\
\hline & ANDESITE (TERTIARY)—Aphanitic gray dikes \\
\hline $\mathrm{Ksg}$ & SCHIEFFELIN GRANODIORITE (UPPER CRETACEOUS) \\
\hline KK & $\begin{array}{l}\text { RHYODACITE (UPPER CRETACEOUS)-Abundantly } \\
\text { porphyritic altered rhyodacite tuff, welded tuff?, } \\
\text { and intrusive rock }\end{array}$ \\
\hline $\mathrm{Kb}$ & $\begin{array}{l}\text { BISBEE FORMATION (LOWER CRETACEOUS)- } \\
\text { Hornfelsed arkosic sandstone and siltstone } \\
\text { NACO GROUP: }\end{array}$ \\
\hline $\mathrm{Pe}$ & $\begin{array}{l}\text { Epitaph Dolomite (Lower Permian)-Medium-gray } \\
\text { dolomite and limestone }\end{array}$ \\
\hline Pc & $\begin{array}{l}\text { Colina Limestone (Lower Permian)-Medium-gray } \\
\text { slightly cherty limestone }\end{array}$ \\
\hline PPe & $\begin{array}{l}\text { Earp Formation (Lower Permian and Upper } \\
\text { Pennsylvanian)-Marlstone, siltstone and thin } \\
\text { limestone units; in section only }\end{array}$ \\
\hline $\mathrm{Ph}$ & $\begin{array}{l}\text { Horquilla Limestone (Upper and Middle } \\
\text { Pennsylvanian)-Light-gray, fine-grained, thin- } \\
\text { bedded, cherty limestone, marble, and hornfels }\end{array}$ \\
\hline Me & $\begin{array}{l}\text { ESCABROSA LIMESTONE (MISSISSIPPIAN)- } \\
\text { Medium-gray, coarse-grained, thick-bedded, } \\
\text { cherty, crinoidal limestone and massive white } \\
\text { marble to north }\end{array}$ \\
\hline 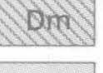 & $\begin{array}{l}\text { MARTIN FORMATION (UPPER DEVONIAN)_-Brown } \\
\text { dolomite, limestone, and sparse sandstone }\end{array}$ \\
\hline Ca & $\begin{array}{l}\text { ABRIGO FORMATION (UPPER AND MIDDLE } \\
\text { CAMBRIAN)-Shale, sandstone, thin-bedded } \\
\text { limestone, and hornfels to north }\end{array}$ \\
\hline & $\begin{array}{l}\text { Sandstone-Marker horizon at base of a ledgy } \\
\text { sandstone unit }\end{array}$ \\
\hline & $\begin{array}{l}\text { Limestone-Marker horizon at top of ledgy limestone } \\
\text { and light-brown calc-silicate unit }\end{array}$ \\
\hline $\mathrm{Cb}$ & $\begin{array}{l}\text { BOLSA QUARTZITE (MIDDLE CAMBRIAN)-Thick- } \\
\text { bedded, coarse-grained brown to light-gray } \\
\text { quartzite }\end{array}$ \\
\hline & $\begin{array}{l}\text { GRANODIORITE (PRECAMBRIAN Y)-Coarse-grained } \\
\text { granodiorite porphyry } \\
\text { APLITE (PRECAMBRIAN Y) }\end{array}$ \\
\hline$x p$ & PINAL SCHIST (PRECAMBRIAN X)—Schist and phyllite \\
\hline 535 & CONTACT \\
\hline & $\begin{array}{l}\text { p. Dotted where concealed. Bar } \\
\text { inthrown side. Half-arrow shows } \\
\text { of slickensides }\end{array}$ \\
\hline & $\begin{array}{l}\text { ARUST FAULT-Showing dip. Sawteeth on thrust } \\
\text { plate }\end{array}$ \\
\hline$\leftrightharpoons$ & $\begin{array}{l}\text { FAULT ON CROSS SECTION-Arrow couple shows } \\
\text { relative movement. Queried where basis for pro- } \\
\text { jection is lacking }\end{array}$ \\
\hline 70 & $\begin{array}{l}\text { STRIKE AND DIP OF BEDS } \\
\text { Inclined } \\
\text { Vertical }\end{array}$ \\
\hline 30 & RRIKE AND DIP OF INCLINED FOLIATION \\
\hline
\end{tabular}

FIGURE 10 (above and facing page).-Geologic map and structure section of part of the Tombstone Hills. Geology by Drewes,1974, and Drewes and C. H. Thorman, 1975. Base from U.S. Geological Survey, 1:24,000, Tombstone (1952); contour interval $25 \mathrm{ft}$. (Figure scale 1:24,000.)

an east-trending fault, and together these blocks and the intervening fault are separated from a western block by a fault that trends north to northwest. The individual structural blocks are underlain by diverse kinds of rock of Precambrian, Paleozoic, and Mesozoic ages, as well as by some Cretaceous and Tertiary dikes. A granodiorite stock, radiometrically dated at 72 m.y., intrudes the northern part of the northeast block and has metamorphosed and in places may also have mineralized the host rocks, as described by Butler, Wilson, and Rasor (1938).

The southeastern structural block provides subtle signs of bedding-plane faulting in a sequence once taken to be unbroken (Gilluly, 1956, pl. 5). This sequence is much like the one just described from the central part of the Dragoon Mountains, except that most of the Precambrian rock is granodiorite, and the overlying sequence includes the Martin Formation and Escabrosa Limestone above the Cambrian formations.

One bedding-plane fault is found along at least part of the basal contact of the Bolsa Quartzite. Along the northern part of this contact, the beds within the quartzite are discordant upon the underlying contact, and some beds even dip in the opposite direction from the fault. Such structural discordance cannot be demonstrated at the southern part of the contact, and so the bedding-plane fault is not shown there, although the fault may extend for the entire length of contact.

Another bedding-plane fault is believed to separate the Abrigo and Martin Formations. In this instance the underlying beds rather than the overlying ones are truncated along the contact, as mapping reveals that some marker beds within the Abrigo lie various stratigraphic distances from the overlying Martin, and others are truncated by it. The fault is actually exposed to the south, and it may also be exposed to the north in the collars of two shafts, but there the rocks are so strongly metamorphosed that the identity of probable limestone mylonite is obscured by recrystallization.

Many east-trending high-angle faults cut this sequence of formations and some merge with the east-trending fault separating the two eastern structural blocks. Two of these faults merge with the bedding-plane fault beneath the Bolsa, suggesting a possible genetic association between the two kinds of faults, such as occurs in many parts of southeastern Arizona between thrust faults and disharmonic normal and tear faults.

The north- and northwest-trending fault cuts all but one of the east-trending faults and also cuts one of the bedding-plane faults and thus generally is the youngest feature. The fault is seen to swing gradually northwest near the stock, rather than being offset stepwise, as shown by Gilluly. Several slivers of rock along this structure are faulted far out 
of their initial stratigraphic position, suggesting either a strong lateral component of movement on the fault or polyphase movement.

In all, this area has had a deformation history much like that of other parts of southeastern Arizona. Bedding-plane thrust faulting occurred after deposition of Cretaceous rocks but before 72 m.y. ago, and northwest-trending strike-slip faults were active after that date. The broader picture around Tombstone further supports this geologic history.

\section{NORTHERN WHETSTONE MOUNTAINS}

The Paleozoic rocks of the northern part of the Whetstone Mountains (fig. 11) are thrust faulted upon the Precambrian basement, much as they were in the Tombstone Hills and central Dragoon Mountains. Furthermore, they are interpreted here to form several small plates bounded in part by bedding-plane faults. But in this area the beddingplane faults change along strike. In places some bedding-plane faults merge and elsewhere they truncate other thrust faults, and two bedding-plane faults merge with tear faults.

The local rock sequence comprises Precambrian granodiorite overlain by Paleozoic formations that extend as high in the section as the Horquilla Limestone of Pennsylvanian age. In plan view, the sedimentary formations are shown to form two prongs that wedge out eastward upon the basement granodiorite. This area was mapped by Creasey (1967), and his map is in accord with mine on the identification and general distribution of map units. Inasmuch as formation identification is not involved in the structural reinterpretation offered below, the cursory descriptions of formations presented on plate 1 suffice. More detailed descriptions were given by Creasey, who also showed each prong to be the site of an east-trending syncline. East-trending faults truncate the south limbs of both synclines. No anticline lies between the synclines; in its stead is one of the east-trending faults, interpreted by Creasey to be a tear fault. Other faults in the southwest part of the area of figure 11 form a jumble, which Creasey did not interpret.

The detailed mapping shown on figure 11 provides several new observations that lead to an alternative structural interpretation of this area. The faults forming the jumbled pattern in the southwest part of the area can be mapped farther northwestward, where they are first seen to cut gently across bedding and then to merge into a single strand. Finally, this strand continues as a bedding-plane fault within the Abrigo Formation, as is inferred from the rapid variation in width of outcrop of that formation southwest of Wildcat Well. The pattern formed by these faults is typical of locally shingled beddingplane thrust plates or schuppen.

While the rocks of some of the small fault plates are synclinally warped, no such fold axis extends through the entire suite of Paleozoic rocks in either prong. Rather, the few folds within single platelets are probably disharmonic structures, and the slight deflection of strike of beds near the east-trending faults are likely the result of drag.

The more northern of the east-trending faults is accepted as a right-lateral tear fault, as proposed by Creasey. This interpretation is supported by the combined evidence of the offset sense of the Paleozoic formations across the fault, the gentle drag of beds just north of the fault, and the sliver of Bolsa Quartzite along it. The other east-trending fault is also viewed as a right-lateral tear fault, for essentially the same reasons. The truncation of faults and thrust platelets suggests that the structurally lower units were formed first and higher ones thereafter, and that the northern plate formed after the southern platelets.

The interpretation that a thrust fault separates the Bolsa Quartzite from the underlying granodiorite along the northern part of both prongs comes from observations and inferences other than the kinds used in the Tombstone Hills or central Dragoon Mountains. These segments of the contact are concealed by talus, and there are no signs of angular discordance between contact and overlying beds. Near its intersection with line $B-B^{\prime}$ (fig. 11), the southern tear fault dips about vertically, and from that point to the end of the prong the dip of the tear fault decreases systematically to about $30^{\circ}$. The fault trace then simply slips around the end of the prong along the sub-Bolsa contact. A fault with such large offset as this tear fault is not likely to die out abruptly, and there is no sign of a fault within the granodiorite, so its continuation northwestward as a bedding-plane fault is plausible. This situation is repeated in the northern prong, where, however, a high-angle fault may be projected a short distance into the granodiorite.

These several new field interpretations may be integrated into a comprehensive and coherent explanation of the structural development of the area. The Paleozoic rocks of the area of the southern prong were separated from the basement on a dêcollement fault that was not entirely planar but included some steeply inclined segments. Together, these irregularities resemble oversized mullion-like features, and their orientation probably indicates 


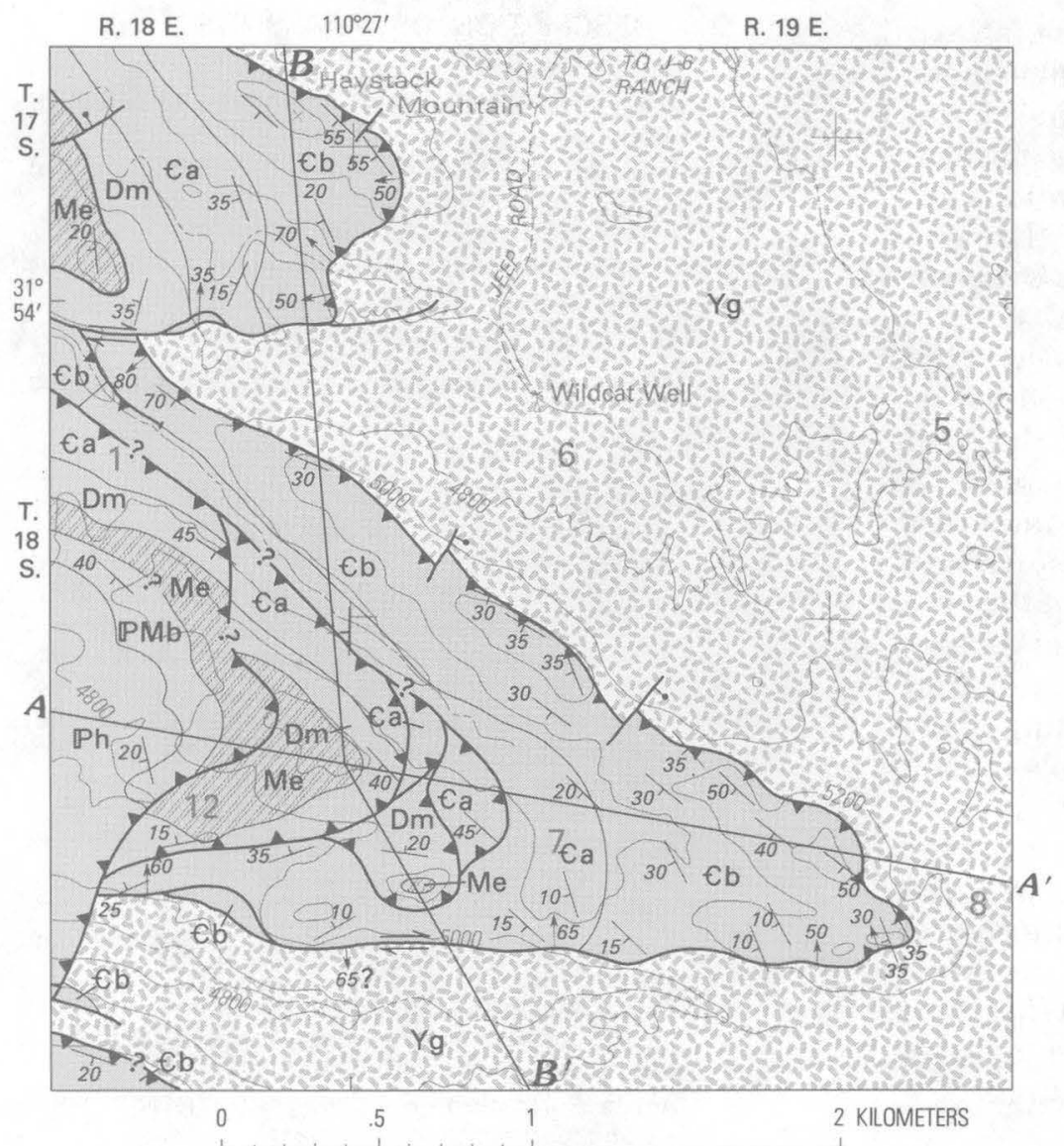

\section{CORRELATION AND DESCRIPTION OF MAP UNITS}

Ph HOROUILLA LIMESTONE (UPPER AND MIDDLE PENNSYLVANIAN)-Finegrained moderately thick bedded cherty limestone

PMB BLACK PRINCE LIMESTONE (LOWER PENNSYLVANIAN? OR UPPER MISSISSIPPIAN)-Moderately thick bedded cherty limestone and some reddish-gray siltstone and red chert clasts

Me ESCABROSA LIMESTONE (UPPER AND LOWER MISSISSIPPIAN)-Thickbedded crinoidal cherty limestone

DM MARTIN FORMATION (UPPER DEVONIAN)-Brownish-gray dolomite, limestone, and some sandstone ABRIGO FORMATION (UPPER AND MIDDLE CAMBRIAN)-Shale, sandstone, and thin-bedded limestone

$\mathrm{Cb}$ BOLSA QUARTZITE (MIDDLE CAMBRIAN)-Thick-bedded quartzite

Yg GRANODIORITE (PRECAMBRIAN Y)Biotite-chlorite granodiorite porphyry and quartz monzonite

\section{CONTACT}

- NORMAL FAULT-Bar and ball on 50 downthrown side

A AHRUST FAULT-Showing dip. Sawteeth on upper plate. Queried where uncertain

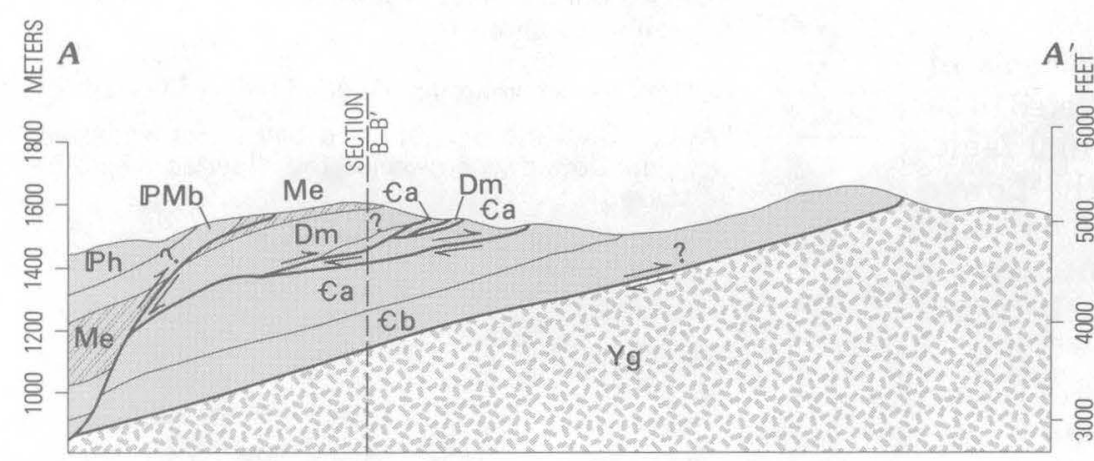

ॠ STRIKE-SLIP FAULT-Showing dip. Arrow couple shows relative move-

ment
$\rightleftharpoons$ ? A FAULT ON CROSS SECTION-Arrow couple shows relative movement. A, movement away from viewer; $T$, toward viewer. Queried where basis for projection is lacking

65 STRIKE AND DIP OF BEDDING

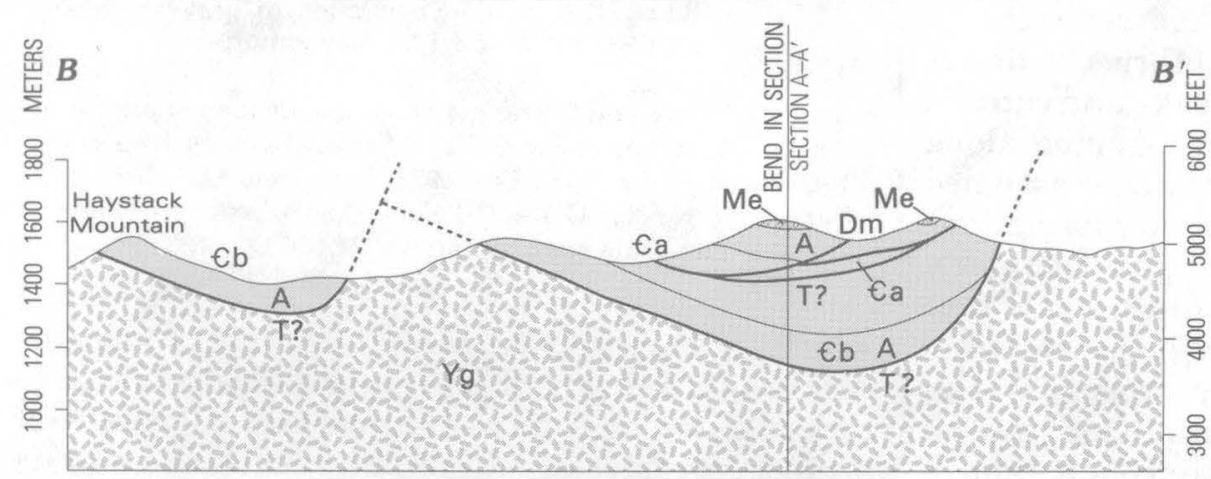

FIGURE 11.-Geologic map and structure sections of the northern Whetstone Mountains. Geology by Drewes, 1972, except the southwestern corner, modified from Creasey, 1967. Base from U.S. Geological Survey, 1:62,500, Benson (1958); contour interval $40 \mathrm{ft}$. (Figure scale approximately $1: 31,680$.) 
transport direction of the thrust plate. Next, overlying platelets formed, probably as movement on the lowest plate ceased. Finally, the thrust platelet or schuppe of the northern prong formed. Similar thrust fault and tear fault combinations are reported in the Santa Rita Mountains (Drewes, 1972a, pl. 4) and in the northern part of the Dragoon Mountains (pl. 2; Gilluly, 1956, pl. 5).

The thrust fault herein inferred to be present at the north end of the Whetstone Mountains need not be large or extensive. Surely the structural regularity of the main part of the range is indicated by Creasey's map, although scattered signs of low-angle faults are also shown. The sub-Bolsa fault at the north end probably extends up the high ridge south of the area of figure 11, where Creasey showed some irregularities of thickness of the Bolsa Quartzite that would be enigmatic without some bedding-plane shearing. For instance, on his map, the Bolsa along the canyon in $\mathrm{NE}^{1 / 4}$ sec. 13 , T. $18 \mathrm{~S}$., R. $18 \mathrm{E}$., is much thinner than the quartzite on the high part of the ridge in the middle of the adjacent section 18 . Even as a potentially minor structural feature, the style of deformation of this area is seen as being consistent with that throughout the region, and the Whetstone Mountains are not entirely without evidence of thrust faulting or compressional deformation.

\section{PERILLA MOUNTAINS}

In the Perilla Mountains 10-15 km northeast of Douglas, a reported thrust fault is reinterpreted to be partly an unconformity and partly a normal fault. Furthermore, there is no evidence that the Lower Cretaceous rocks were thrust upon younger ones prior to the normal faulting, and very likely a normal sequence would show an unconformity between these rocks.

A thrust fault is reported to emplace Lower Cretaceous rocks of the Bisbee Group upon Upper Cretaceous or Tertiary volcanic and sedimentary rocks (Cooper, 1959). This reported thrust fault lies low on the west flank of College Peaks and extends west of U.S. Highway 80. Detailed mapping along this contact (fig. 12) indicates that the ages assigned to some of the volcanic and sedimentary formations should be revised. These changes, plus some new observations along the critical contact, show that the local geologic regime fits the regional pattern.

The Cretaceous and Tertiary volcanic and sedimentary rocks of Cooper are here divided into an older clastic unit, a dacitic volcanic unit, and a younger clastic unit. The older clastic unit comprises shale, siltstone, sandstone, and conglomerate in alternating and gradational units. The detritus of

\section{DESCRIPTION OF MAP UNITS}

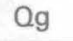

QTg

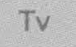

Trw
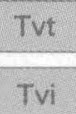

Tc

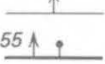

$55 \uparrow$.

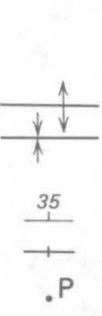

GRAVEL AND SAND (QUATERNARY)-Alluvium of floodplains and low terraces

GRAVEL (QUATERNARY AND TERTIARY)-Alluvium of high terraces and pediment(?)

RHYOLITE (MIOCENE AND OLIGOCENE):

Volcanic rocks, undifferentiated-Mainly tuffaceous rocks; east of highway

Welded tuff-Generally caps hills west of highway

Tuff-Mainly beneath, and locally capping welded tuff

Intrusive rocks

CONGLOMERATE (OLIGOCENE?)-Poorly consolidated light-pinkish-gray pebble conglomerate and sandstone

DACITIC VOLCANIC ROCK (TERTIARY? AND CRETACEOUS?)-Chiefly greenish-gray altered flow breccia; includes some epiclastic dacitic beds SEDIMENTARY ROCK (UPPER CRETACEOUS?)Medium-gray to olive-gray shale, siltstone, feldspathic sandstone, and conglomerate; conglomerate contains mainly dacitic clasts, possibly derived from an older part of the dacitic volcanic rock sequence, such as occurs north of area of this map

BISBEE GROUP (LOWER CRETACEOUS):

Cintura Formation-Reddish-gray siltstone and sandstone

Mural Limestone-Light-gray limestone in thin beds and moderately thick lenses, that are intercalated in reddish-gray siltstone and shale

Morita Formation-Reddish-gray siltstone, sandstone, and some conglomerate

Glance Conglomerate-Gray limestone pebble and cobble conglomerate

CONTACT-Showing dip. Queried where inferred

FAULT-Showing dip. Bar and ball on downthrown side. Dotted where concealed. Queried where inferred

FOLD-Showing trace of axial plane:

Anticline

Syncline

STRIKE AND DIP OF BEDS:

Inclined

Vertical

COLLECTION SITE-Specimens of gray shale and siltstone examined for palynomorphs

Figure 12 (above and facing page).-Geologic map of part of the Perilla Mountains near College Peaks. Geology by Drewes, 1968, assisted by G. K. Lee, 1972. Base from U.S. Geological Survey, 1:62,500, College Peaks (1958); contour interval $40 \mathrm{ft}$. (Figure scale approximately 1:31,680.)

which these rocks were made is largely of volcanic rock origin, and probably the source was nearby. The rock color typically has a greenish cast, suggestive of a mild pervasive alteration. The black shale units appeared devoid of palynomorphs, and no macrofossils were found either. Provisionally, these rocks are correlated, on their lithology alone, with the 


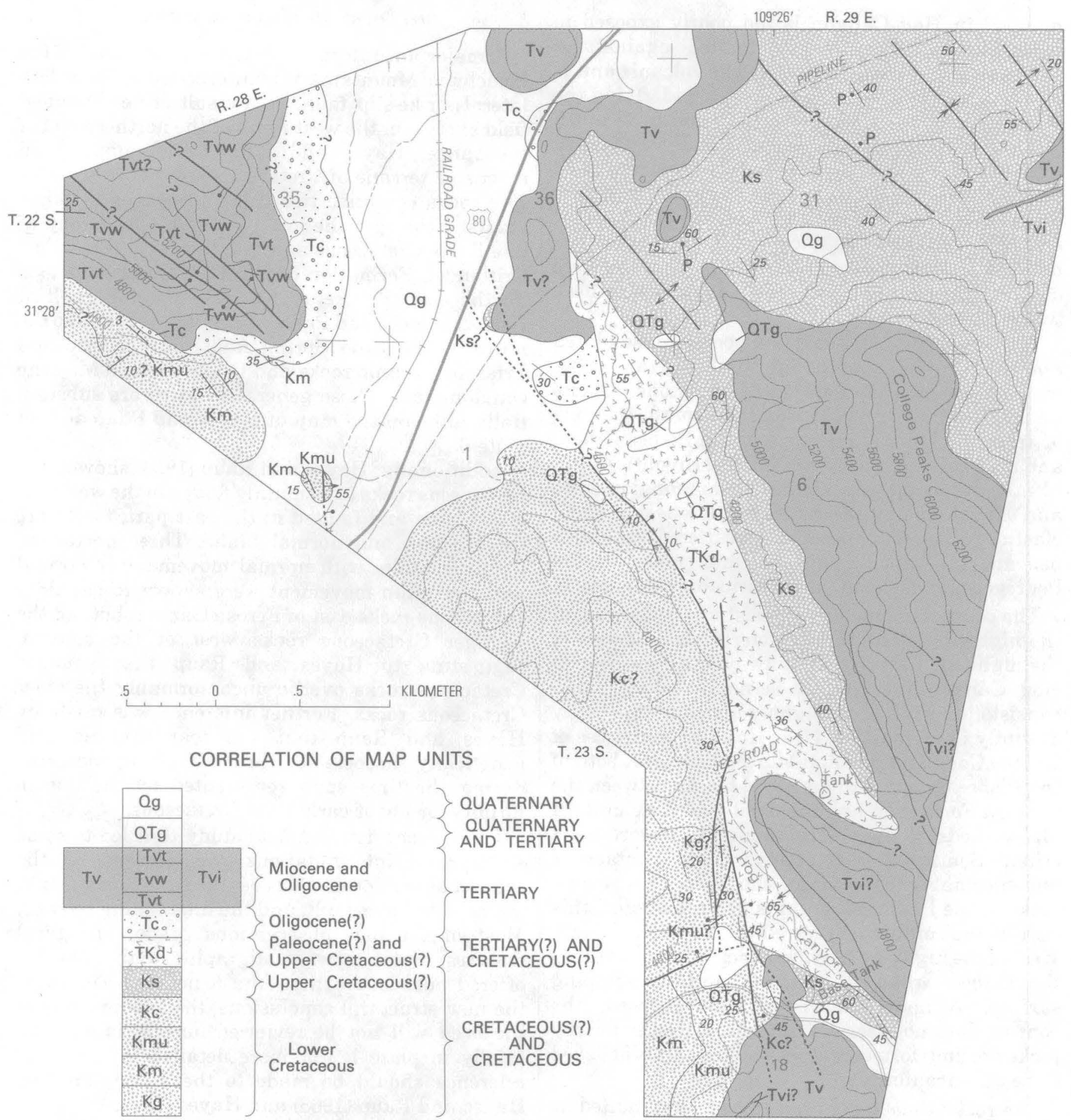

upper part of the Fort Crittenden Formation, of Late Cretaceous age. North of College Peaks the older clastic unit is warped into several northwesttrending open folds.

The dacitic volcanic unit appears to lie conformably upon the older clastic unit, and it may interfinger with it several kilometers north of
College Peaks and north of the area of figure 12. The rock is mainly flow breccia, but some intercalated epiclastic rocks occur in widely scattered places. The volcanic rocks resemble the underlying unit in having a greenish-gray color, in this instance probably the result of propylitization of ferromagnesian minerals. The small mass of clastic rocks 
mapped in Hog Canyon is too poorly exposed to determine whether it was faulted against, or deposited on, the volcanic unit. The volcanic unit is probably correlative with the rocks underlying the low area south of Castle Dome, $10 \mathrm{~km}$ to the north (see pl. 5). It may also be genetically related to andesitic and dacitic rocks to the west and east, such as the Sugarloaf Quartz Latite and part of the Salero Formation, of late Late Cretaceous age (70-73 m.y.), and the andesitic volcanics of the northern Pyramid Mountains of New Mexico, of Paleocene(?) age (54.9-67.3 m.y.), and may be of an age between these two groups of rocks.

The younger clastic unit is a poorly consolidated and thus poorly exposed, light-pinkish-gray pebble to boulder conglomerate and sandstone. Clasts include limestone derived from Paleozoic formations or from the Mural Limestone of the Bisbee Group, and matrix is tuffaceous material of rhyolitic origin like the overlying volcanic rocks. This conglomerate and sandstone unit resembles small lenses of basal clastic rocks that occur at scattered localities beneath the mid-Tertiary volcanic rocks in the Pedregosa, Swisshelm, and Chiricahua Mountains.

The contact mapped as a thrust by Cooper east of the highway differs in character from that west of the highway. East of the highway and extending to Hog Canyon the contact is nearly vertical and consists of several straight segments that vary abruptly in orientation. Near Hog Canyon, slices of Glance Conglomerate and Mural Limestone, both of the Bisbee Group, form upended blocks between the Cintura Formation and the dacite volcanic unit. In places, beds of these formations dip toward each other. South of Hog Canyon the contact is unconformably covered by the Tertiary volcanic rocks of the Perilla Mountains. All considered, this part of the contact is inferred to be a normal fault. West of the highway the younger clastic unit overlies the Bisbee Group on a gently northeast-dipping surface. Although nowhere fully exposed, the. contact does not seem to be faulted, for the nearby rocks are undeformed; rather, this contact is believed to be an unconformity.

The rocks thus appear not to be thrust faulted at the present level of exposure, but are nevertheless interrelated in a way that fits the regional pattern. The Upper Cretaceous rocks first were deposited on the Bisbee Group and then were altered and compressively folded, presumably during the time of the Cordilleran orogeny. Subsequently they were faulted and deeply eroded. They then were covered by local lenses of gravel, and finally by widespread rhyolite volcanic deposits.

\section{NORTHERN HUACHUCA MOUNTAINS}

A major unconformity in the northern part of the Huachuca Mountains is reinterpreted to be a leftlateral strike-slip fault, as a result of new detailed field study. On the west flank of the northern end of the range, Hayes and Raup (1968) mapped an extensive terrane of Cretaceous sedimentary rocks. The rocks comprise two thick sequences of fairly similar lithology; the lower is the Bisbee Group of late Early Cretaceous age, and the upper is the Fort Crittenden Formation of late Late Cretaceous age. To the east the Cretaceous rocks overlie a belt of Paleozoic rocks and Precambrian granite, and to the north of the Kino Spring fault are Jurassic and Triassic volcanic rocks and Oligocene and Miocene conglomerate. These general features are substantially alike on the map of Hayes and Raup and on plate 6.

Additionally, Hayes and Raup (1968) showed the Cretaceous rocks to be mainly folded in the west part of the area and faulted in the east part; faults are thrust, tear, and normal faults. Three northeasttrending faults with normal movement or normal and strike-slip movement were shown to cut older Cretaceous rocks east of Ferosa Canyon but not the younger Cretaceous rocks west of the canyon, suggesting to Hayes and Raup that younger Cretaceous rocks overlie unconformably the older Cretaceous rocks. Further inference was made by Hayes and Raup that the tear faulting and genetically associated thrust faulting occurred during the time span represented by the unconformity, or about early Late Cretaceous.

The present detailed field study that led to some structural reinterpretations was focused on the contact along Ferosa Canyon, the Kino Spring fault, the reported tear fault, and the intervening terrane. Most of the new observations are of structural features. Some new stratigraphic data also are offered, but because these data do not form a basis for the new structural conclusions, the stratigraphy of the area will not be reviewed here; it is outlined briefly in plate 1. For more detailed information, reference should be made to the descriptions by Hayes and Raup (1968) and Hayes (1970a).

A few stratigraphic points are noteworthy, although the structural changes are not based on stratigraphic reinterpretations. In recent years, Hayes and I have agreed that the andesite lava intercalated with conglomerate of the Glance of this area should be excluded from the Glance and the Bisbee and treated as a separate formation. This lower part of the Glance may prove to be correlative with the Lower Cretaceous Temporal and Bathtub 
Formations, which are post-Squaw Gulch and preBisbee in age in the Santa Rita Mountains, $25 \mathrm{~km}$ to the west. For simplicity, however, the stratigraphy of Hayes and Raup (1968) is retained in this study.

Several detailed features in the formations of the Bisbee Group provide structural evidence. Some informal members of the Glance Conglomerate are mapped separately, and the thickest sandstone units intercalated in the shale and siltstone of the Morita and Cintura Formations are mapped as marker beds (pl. 6). In places these stratigraphic features are systematically offset to indicate the presence of concealed faults. Elsewhere they show continuity across zones of previously proposed faults. And near some of the major faults, the traces of these beds are systematically bent and probably reflect movement along the faults.

In the northwestern part of the area of plate 6, quartz monzonite, here assigned a Late Cretaceous(?) age, occurs in a structural slice along the Kino Spring fault. The Bisbee Group is hydrothermally altered only near this quartz monzonite, suggesting. a genetic relation of the alteration to that rock. More specifically, a concealed but nearby stock probably caused the alteration, and subsequently a slice of the stock was brought up by faulting. In this case the main strand of the fault probably lies along the north sides of the slice. Another such slice lies along the Kino Spring fault near the northeast corner of plate 6. The quartz monzonite is assigned a Late Cretaceous(?) rather than a Jurassic(?) age, as shown by Hayes and Raup (1968), because Lower Cretaceous rocks have been altered near the igneous rock. This explanation, involving a single, largely concealed stock of Late Cretaceous(?). age, is preferred because the alternative requires an inferred Jurassic(?) stock-relatively rare features-plus an inferred concealed Upper Cretaceous stock.

The critical contact between Lower and Upper Cretaceous rocks near Ferosa Canyon is reinterpreted to be a fault. In most places the fault comprises two strands and near its juncture with the Kino Spring fault it forms more strands. The trace of the fault across local topographic features suggests that it is nearly vertical, and the few actual exposures of parts of two fault strands show them to dip $80^{\circ}$ east. However, the actual fault plane is commonly concealed because it follows zones of shaly rocks. The continuity of the fault is nevertheless inferred because of the alinement of disrupted and warped beds near the critical contact. Marker beds in the block east of the contact are truncated and systematically bent along the fault in a manner indicative of left-lateral movement. The beds between two strands of the fault in the east half of section 2 are likewise dragged, but movement of the fault slice was complex, or the slice is broken by internal faults, for the Mural Limestone is offset in a right-lateral sense, opposite that implied by the warping of the sandstone marker beds. Beds between two strands of the fault $1 \mathrm{~km}$ west of Anderson Mine are upended or slightly overturned and are not believed to be the overturned limb of a major fold, as indicated by Hayes and Raup (1968).

The Kino Spring fault is shown by the present study to be a north-dipping structure that probably has a complex movement history. Different rock sequences are juxtaposed, slices of quartz monzonite not exposed in adjacent walls occur along it, and beds of the footwall are warped to the left near it. The Oligocene to Miocene Pantano Formation is found only to the north of the fault, suggesting possible deposition in a fault-bounded basin. Folds in Cretaceous rocks in and just beyond the northwest corner of the area, a thrust fault, and a belt of much faulted Paleozoic and Precambrian rocks are all truncated by the Kino Spring fault. The entire belt of Paleozoic rocks seems to be dragged left-laterally along the Kino Spring fault.

In this area there is evidence of three times of deformation. The oldest deformation formed folds and thrust faults after deposition of the Upper Cretaceous Fort Crittenden Formation and before strike-slip movement on the Kino Spring fault. This deformation may be the main phase of the Cordilleran orogeny, of latest Cretaceous age. The second deformation is one in which there was strikeslip movement on the Kino Spring fault. This deformation truncates the features formed by the older deformation and it may predate the deposition of the Pantano Formation. It could be an expression of the late phase of the Cordilleran orogeny, of Paleocene age. The third time of movement may be a normal movement on the Kino Spring fault that dropped the formation into a broad graben extending northward from the area of plate 6 about $10 \mathrm{~km}$ to the southern Mustang Mountains of plate 7. This latest movement would be Oligocene or younger. The development of the structures of the northern Huachuca Mountains discussed here resembles the geologic history of the rest of southeastern Arizona; the style and timing of deformation are regionally uniform. During the oldest time of deformation, the Cretaceous rocks near the west edge of plate 6 and the thrust faults were both folded. 


\section{REINTERPRETATIONS OF THRUST FAULTS} AND STRIKE-SLIP FAULTS

In the southern Mustang Mountains, northern Mule Mountains, and southeastern Winchester Mountains, new evidence is available that major faults once reported as thrust faults are actually strike-slip faults. These reinterpretations are based mainly on observations of structural details on and near the faults and not largely on stratigraphic reassignments. Therefore, few of the rocks of these areas will be described here in greater detail than appears on their respective map explanations and on plate 1 .

\section{SOUTHERN MUSTANG MOUNTAINS}

The southernmost hills of the Mustang Mountains, lying along the Babocomari River, were reported by Hayes and Raup (1968) to be underlain by one sequence of rocks of Permian to Jurassic age thrust faulted over another sequence of mid-Tertiary rocks. The thrust fault was viewed as dipping gently to the north, but few data were presented that bear on the direction of movement along the fault. Detailed remapping of the area leads me to believe that the major fault is moderately to steeply inclined and has a large left-lateral component of movement, and that movement occurred mainly before, rather than after, the mid-Tertiary rocks were deposited.

The low hills along the north side of the river are underlain mainly by Paleozoic rocks and Jurassic and Triassic rocks. Their identity and general distribution are well shown on older maps; thus, plate 7 only adds detail, such as subdivisions of several formations. Descriptions of the Paleozoic formations were given by Gilluly, Cooper, and Williams (1954) and Creasey (1967), and the Jurassic and Triassic rocks were described by Hayes, Simons, and Raup (1965) and Drewes (1971c). Two small masses of Glance Conglomerate and others of Triassic(?) red sandstone and siltstone lie along the Babocomari fault, and a plug of porphyritic rhyolite, probably of latest Cretaceous or Tertiary age, intrudes it. South of the Babocomari fault and underlying the river lowland are rocks here identified as the Fort Crittenden Formation of late Late Cretaceous age, and the Pantano Formation of Oligocene and Miocene age. The Mesozoic rocks are in part newly recognized in this area and are described below because the reinterpretation of the age of movement is based on the identification of these formations.

Red beds that resemble the Triassic Gardner Canyon Formation overlie the Permian Concha Limestone and underlie the Jurassic and Triassic volcanic rocks. The red-bed unit comprises largely siltstone, mudstone in which are intercalated some sandstone beds, and a few beds of pinkish-gray limestone. This unit is redder and more massive than any of the Cretaceous formations that contain red beds.

Reddish-gray rhyolite or rhyodacite, flow-laminated tuff, and welded tuff overlie the red beds. Flow laminations mostly parallel the nearby part of the basal contact but locally they diverge from that contact. The volcanic rocks resemble either the Canelo Hills Volcanics or, less closely, volcanics of the Mount Wrightson Formation.

The basal contact of the red beds with Paleozoic rocks is concealed; however, inasmuch as the older rocks contain many more faults than the adjacent younger ones and there is no record of Late Permian or Early Triassic faulting anywhere in the region, the contact is probably faulted.

The Glance Conglomerate is a thick, poorly bedded unit. Its clasts commonly consist of Paleozoic limestone and are of pebble to cobble size.

Reddish-brown to moderate-red, well-indurated siltstone, shale, and sandstone south of the Babocomari fault are here believed to be correlative with the Fort Crittenden Formation of Late Cretaceous age. Within the red-bed sequence are a bed of laminated limestone $10 \mathrm{~cm}$ thick, several beds of rhyolitic tuff and tuffaceous sandstone each 2-15 cm thick, a fanglomerate bed 20-25 m thick, and scattered beds of well-sorted conglomerate and of gritty conglomerate. The clasts of the fanglomerate comprise volcanic rock, limestone and other lithologies of Paleozoic age, and red siltstone. The tuffaceous beds and volcanic-clast conglomerate are typical of the upper part of the Fort Crittenden Formation in the Santa Rita Mountains (Drewes, 1971c). The red beds and the limestone bed also resemble rocks in the Bisbee Group, but the lithologies of the Pantano Formation, with which the red beds had been correlated, are considerably different.

The Pantano Formation of Oligocene and Miocene age is a weakly to moderately indurated pinkishgray to reddish-gray sandstone and siltstone. It lies unconformably upon, or may be faulted against, the better indurated darker colored beds of the Fort Crittenden Formation. Some tuffaceous sandstone is intercalated in the formation and at one horizon the formation also contains a unit of weakly indurated air-fall(?) tuff several tens of meters thick (pl. 7, unit Tpt ). This air-fall tuff unit has about 30 percent crystals and crystal fragments, including biotite, quartz, plagioclase, sanidine, magnetite, 
apatite, and zircon, all set in a granular cryptocrystalline groundmass, in which a relict shard texture is preserved. The biotite of specimen 68D35 was radiometrically dated by Marvin and others $(1973$, p. 19 , specimen 71$)$ as about 39 m.y. old. A lava flow of olivine basalt, about $20 \mathrm{~m}$ thick, is intercalated in the Pantano Formation stratigraphically above the tuff beds. It has 10 percent phenocrysts, mainly of plagioclase, pyroxene, and olivine, although some are of amphibole, magnetite, and apatite.

The Paleozoic and Mesozoic rocks of the southern Mustang Mountains are much faulted and locally folded. The style of faulting in the older rocks north of the Babocomari fault differs from that in the younger rocks farther south, suggesting that the Babocomari fault has a large offset, as already indicated by Hayes and Raup (1968). Bedding-plane faults and other crosscutting faults occur within the Paleozoic rocks, and a high-angle fault of unknown kind separates the Paleozoic rocks from the Jurassic and Triassic rolcanic rccks (pl. 7).

The Babocomari fault is exposed in many places over a distance of about $3 \mathrm{~km}$, and is seen to dip from $80^{\circ}$ south, past vertical, to $45^{\circ}$ north. Near the eastern end of the fault, the Fort Crittenden Formation of the south wall is warped into small, tight drag folds that abut the fault. Axial planes of these folds strike northwest and dip steeply southwest, as is approximately shown on plate 7 by the bedding attitude of one of the overturned limbs. Near the middle of the fault trace and the easternmost fault block of Triassic(?) red beds, striae on the fault plane are subhorizontal. Nearby, red siltstone and marlstone beds of the basal member of the Scherrer Formation in the north wall of the fault are dragged eastward along the fault. A few north and northeast-striking cross faults cut the Babocomari fault, and the porphyry plug appears to intrude it.

The new observations suggest that the Babocomari fault is a major strike-slip structure. The evidence of direction of that movement is sparse. Drag folds suggest left-lateral movement, and the pattern of faults splaying off the Babocomari fault also resembles that on left-lateral faults elsewhere in the region. That the fault is a major one is implied locally through its separation of markedly different geologic terranes; it is also implied regionally because it strikes into major strike-slip faults to the east and west (Drewes, 1980). Major fault movement occurred during the interval after deposition of the Fort Crittenden Formation and possibly also after activation of the thrust faults in the area of plate 7 , but before the emplacement of the rhyolite plug. If the fault between the Paleozoic rocks and the Jurassic and Triassic rocks has similar movement history, then the Paleozoic block may form a large horse along a strike-slip fault zone. But in any case, no evidence was found to support the interpretation that the fault is a thrust fault. Minor(?) thrust faulting within the Paleozoic rocks probably is older than the strike-slip movement, but conceivably these events were coeval. A few cross faults are younger than the Babocomari strike-slip fault and, inasmuch as one of these cross faults has dropped Pantano against the Paleozoic rocks and another seems to offset the basalt in the Pantano, these faults are Oligocene or younger.

The study of the features along the Babocomari River, then, shows that major southward overthrusting of mid-Tertiary age is a less likely interpretation than is an episode of thrusting, followed by Cordilleran strike-slip faulting and postPantano normal faulting.

\section{NORTHERN MULE MOUNTAINS}

In the northern Mule Mountains, about midway between Tombstone and Bisbee, Gilluly (1956, pl. 5) mapped a fault zone that strikes due east, emplaces a wedge of older rock between younger ones, and dies out just east of this infaulted wedge of rock. $\mathrm{He}$ interpreted the structural feature as a steeply northward-dipping thrust fault (Gilluly, 1956, pl. 6, sections XXVII-XXIX), along which the upper plate moved a short distance southward during postBisbee time. As a result of new observations and refinements in the mapping (fig. 13), I propose that this structural feature is a through-going strike-slip fault zone having possible left-lateral movement.

The area covers parts of three geologic terranes. The fault zone itself is marked by a wedge of rocks of Cambrian to Mississippian age that dip steeply, strike across the trend of the zone in some places, and are folded in other places. Two small bodies of the Glance Conglomerate Member of the Bisbee Formation are also part of the fault zone. These rocks are separated by minor faults into several lenticular masses oriented parallel to the fault zone.

The terrane south of the fault zone consists entirely of rocks of the upper member of the Bisbee Formation, as Gilluly mapped it-probably the Cintura Formation, upper formation of the Bisbee Group of Hayes and Landis (1964). These rocks dip gently southward, except adjacent to the fault zone, where they dip steeply to the south and locally are overturned.

The terrane north of the fault zone consists largely 


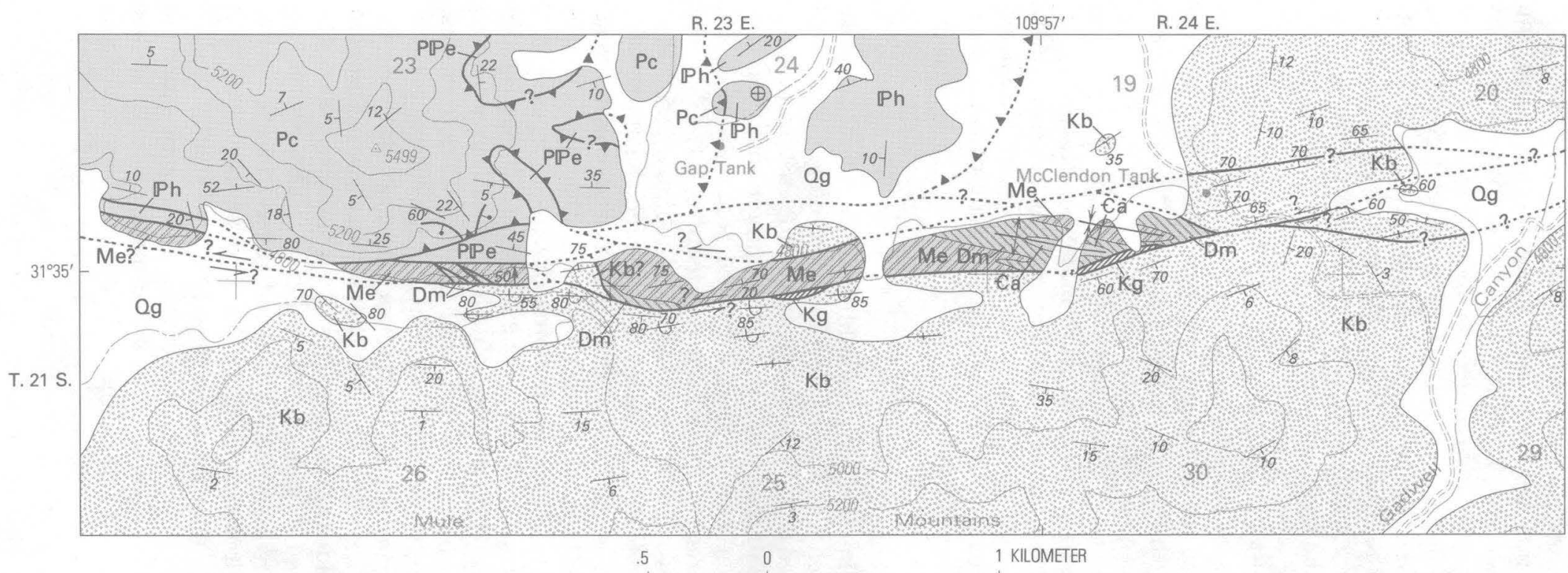

CORRELATION AND DESCRIPTION OF MAP UNITS

Qg GRAVEL (QUATERNARY)—Alluvium of floodplains and terraces

BISBEE FORMATION (CRETACEOUS):

$\mathrm{Kb}$. Upper member-Olive-gray siltstone, shale, and sandstone

Glance Conglomerate Member-Limestone pebble and cobble conglomerate

NACO GROUP:

Colina Limestone (Lower Permian)-Medium-gray sparsely cherty limestone

Earp Formation (Lower Permian and Upper Pennsyl-

vanian)-Pale-red siltstone and marlstone
Ph Horquilla Limestone (Upper and Middle Pennsylvanian)-Light-gray cherty limestone

Mo. ESCABROSA LIMESTONE (UPPER AND LOWER MISSISSIPPIAN)-Massive crinoidal limestone

DEN MARTIN FORMATION (UPPER DEVONIAN)—Brown dolomite and gray limestone

€a

1 KILOMETER

FIGURE 13.-Geologic map of the northern Mule Mountains northwest of Gadwell Canyon. Geology by James Gilluly, 1956; modified by Drewes, assisted by G. K. Lee, 1972. Base from U.S. Geological Survey, 1:62,500, Gleeson (1958); contour interval $40 \mathrm{ft}$. (Figure scale approximately $1: 31,680$. 
of rocks of the Horquilla Limestone, Earp Formation, and Colina Limestone, collectively of Pennsylvanian to Permian age. To the east this terrane also includes siltstone and sandstone of the upper member of the Bisbee Formation. Dips are mostly gentle and dip directions varied. On the basis of data obtained north of the area of figure 13, Gilluly mapped two thrust faults, largely concealed by gravel deposits, bounding the east-trending fault zone. I suggest that another thrust fault, perhaps only a local bedding-plane fault, overlies the Earp Formation and Horquilla Limestone north of the east-trending zone, where disharmonic structures occur.

The strands of the east-trending fault zone are mostly concealed. In one place a small segment of a fault plane is seen to dip $50^{\circ}$ north; elsewhere the traces of the fault strands seem to be steeply inclined. Interpretations of fault movement consequently must be based on indirect evidence. The lenticular masses, or slices, of rock that occur along the fault zone are typical of any kind of fault, but are more common along faults formed in response to local compressive stress than along tensional faults. The presence among the fault slices of rocks not found in the immediately adjacent wall rocks is usually evidence either of strike-slip movement or of recurrent movement, or both. Strike-slip fault movement is also indicated by the presence of the tight folds that trend oblique to, and abut, a mapped fault strand. Such folds are viewed as having formed under differential compressive stress along the fault, rather than under a simple compressive stress applied prior to movement on the fault.

Left-lateral movement is inferred, but this inference is not made as confidently as the interpretation of strike-slip movement. The orientation of the folds with respect to the strike of the faults favors leftrather than right-lateral movement, for the strain axis of maximum compression, which lies at right angles to the axial planes of the folds, would only develop with left-lateral movement. Furthermore, the more eastern slice of the Glance Conglomerate Member is lodged at a bend in the fault that could have produced a local field of relatively low pressure in the presence of left-lateral movement. An exotic block from a lower structural position, such as the Glance, would tend to migrate toward such an area of low pressure.

The interpretation that the strike-slip fault zone is a major feature comes from regional considerations.
Segments of faults having a similar orientation and a possibly similar age and kinematic history occur both to the east in the Swisshelm Mountains and to the west between the Mustang and Huachuca Mountains, on strike with the fault zone in the northern Mule Mountains. In consideration of a regional scarcity of east-trending strike-slip faults, it is likely that three such alined fault segments are genetically related.

\section{WINCHESTER MOUNTAINS}

On the southeastern flank of the Winchester Mountains, $12 \mathrm{~km}$ west of Willcox, thrust faults have been reported to cut rocks of a small inlier of older rocks beneath a cover of mid-Tertiary volcanic rocks (Cooper and Silver, 1964, pl. 1). Detailed mapping by C. H. Thorman and me that was aimed at getting further information about these faults provided evidence to suggest that the structural feature is probably part of a major left-lateral strike-slip fault zone. Although only a small part of the inlier is shown on Cooper's map, most of it is shown on figure 14 of this report, and all of it is shown, in a generalized way, by Creasey, Jackson, and Gulbrandsen (1961).

The rocks along the fault zone comprise mainly Paleozoic limestone and quartzite and Precambrian granodiorite porphyry. They also include small intrusive bodies of Precambrian diorite and small fault wedges of Cretaceous siltstone and Oligocene(?) rhyolitic rocks. Other rhyolitic volcanic rocks were emplaced by landsliding across part of the fault zone from the higher hills southwest of the fault zone before the present topography was developed. The main rock types of the fault zone are cut by many high-angle faults that trend mainly northwestward subparallel to the zone. Small slivers of Paleozoic rocks have been wedged between larger blocks of Precambrian rock along some fault strands, and some of the rhyolitic rocks are infaulted from the adjacent walls. In places these wall rocks and fault slivers are silicified. The various strands of the fault zone dip steeply, most of them to the northeast. Slickensides in two places show that during the latest movement the dip-slip and lateral slip components were about equal.

The terrane northeast of the fault zone is underlain by rhyolitic rocks of Oligocene(?) age. Gravel deposits of Tertiary and Quaternary age lap across all older rocks and the fault zone.

Southwest of the fault zone, Tertiary volcanic 
rocks cap the Winchester Mountains and lie unconformably on moderately steeply southwestdipping clastic rocks of Late Cretaceous age. Large masses of volcanic rocks slid off the highest terrain onto the Upper Cretaceous rocks. The ubiquitous gravel deposits lap up on these formations, too. The faults in the nearby parts of the volcanic terranes are subparallel to the fault zone itself, but these features are simple normal faults with relatively small displacement.

The identification by Cooper and Silver (1964) of a thrust fault between the overlying Cambrian and Pennsylvanian rocks and the underlying Precambrian rocks seems to have been based on the low angle of inclination of the intervening fault. This low-angle character is here reinterpreted, and so there is no basis for considering the fault to be a thrust feature. On the hill in the center of the $\mathrm{NE}^{1 / 4}$ sec. 5, R. 23 E., T. 14 S. (fig. 14), Thorman and I found the capping Horquilla Limestone to consist of a series of small slices of rock that are bounded by high-angle faults and offset from each other by small amounts, and that thereby mimic a flat-lying plate.

Very likely the movement on the strike-slip fault was recurrent. An older stage of movement occurred after deposition of the Upper Cretaceous clastic rocks and before the deposition of the Tertiary volcanic rocks. At that time the older rocks were intensely sheared; the amount of movement was probably large and its direction left-lateral. After deposition of the rhyolite, the fault zone was reactivated and some other faults near the fault zone were also developed. This movement was a mixture of block faulting, typical of the Basin and Range province, and of some left-lateral offset.

The southeastern flank of the Winchester Mountains, then, is seen to record strike-slip movement on a northwest-trending fault of an age appropriate for correlation with late Cordilleran regional deformation. The fault was reactivated at the time of development of Basin and Range structural features, but it contains no record of the strong compressional deformation that typified the middle phase of the Cordilleran orogeny in areas farther south.

\section{OTHER FIELD STUDIES}

Not all of the local field studies supporting the regional tectonic investigation were designed to check previous studies or to support new interpretations; some were simply aimed at obtaining data where there were none. Previous studies were either too general in scope or were focused on topics other than structural geology, and yet the areas

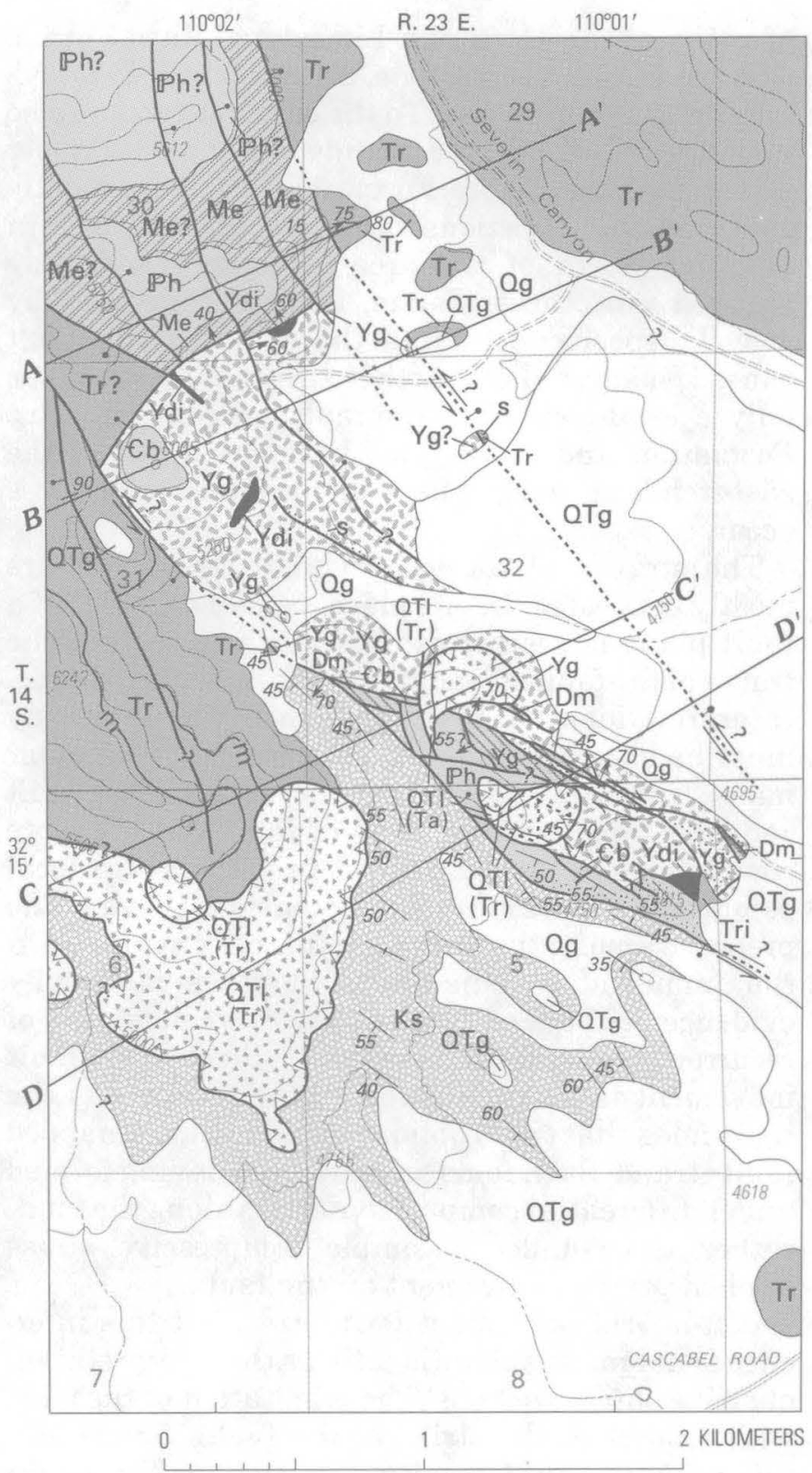

are known to be underlain by rocks old enough to have been deformed during the Cordilleran orogeny. Field studies of this kind cover much of the Ruby quadrangle, west of Nogales, the northern end of the Tumacacori Mountains, the southern part of the Mule Mountains, part of the Tucson Mountains, and the central Chiricahua Mountains.

\section{RUBY QUADRANGLE}

The south-central and southwestern parts of the Ruby quadrangle (pl. 8), including parts of the Ruby mining district and the Pajarito and Atascosa Mountains, are underlain by Cretaceous 

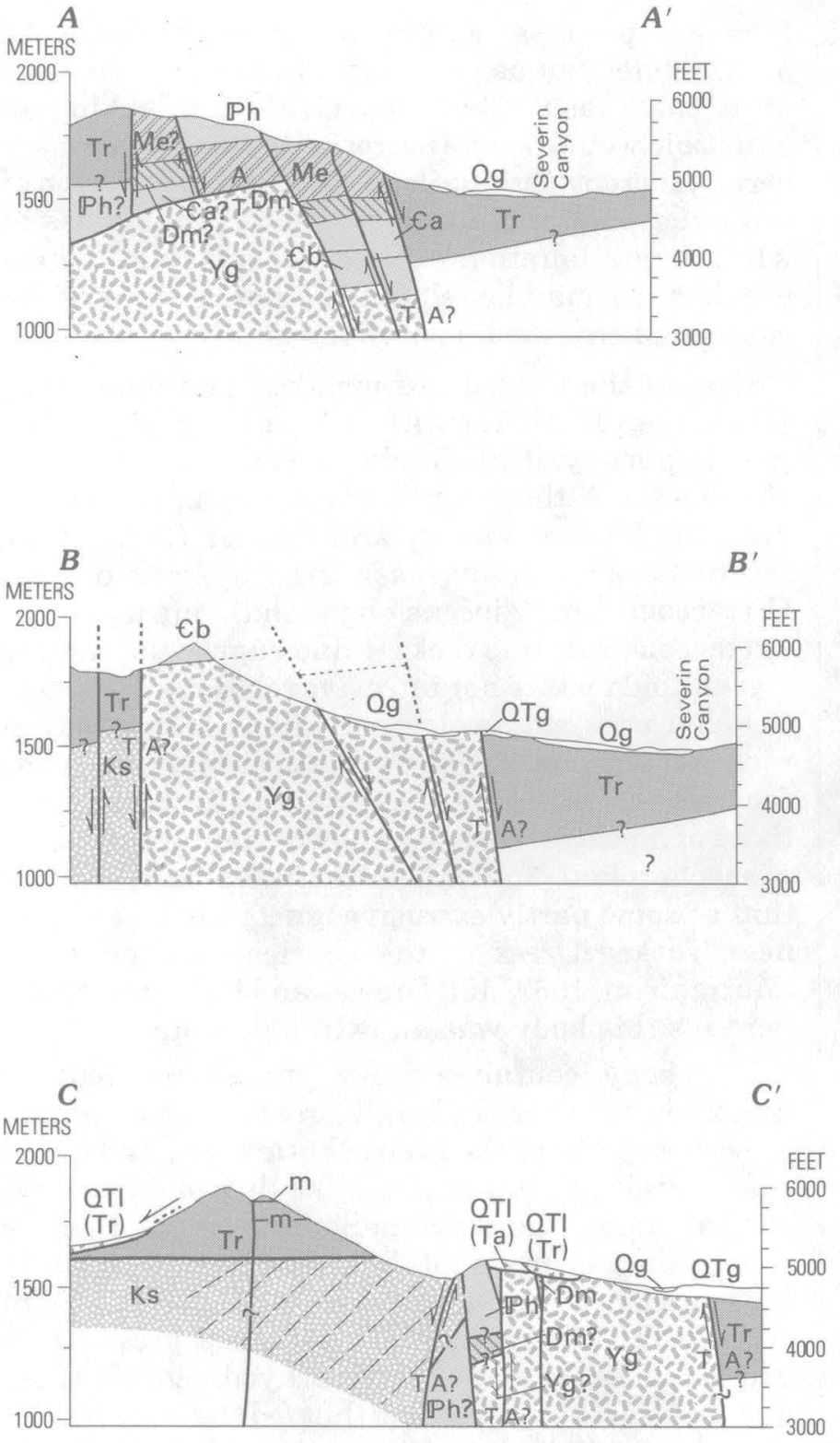

CORRELATION AND DESCRIPTION OF MAP UNITS

Og GRAVEL (HOLOCENE) -Alluvium on Iow terraces

QTg GRAVEL (PLEISTOCENE AND PLIOCENE)-Alluvium on pediment

LANDSLIDE AND SLUMP DEPOSITS (PLEISTOCENE AND PLIOCENE)-Source units: (Tr), rhyolite; (Ta), basaltic andesite with abundant large feldspar phenocrysts

Tr RHYOLITE (OLIGOCENE?)-Tuff, lava, and sedimentary rocks

Tri RHYOLITE INTRUSIVE (OLIGOCENE?)-Sparsely porphyritic

KS SEDIMENTARY ROCKS (UPPER CRETACEOUS)Sandstone, shale, and conglomerate

Ph HOROUILLA LIMESTONE (PENNSYLVANIAN)—Thinbedded, fine-grained, cherty limestone

Me ESCABROSA LIMESTONE (MISSISSIPPIAN)-Thickbedded, coarse-grained, crinoidal, cherty limestone

DIV MARTIN FORMATION (UPPER DEVONIAN)—Dolomite and limestone

Ca ABRIGO FORMATION (UPPER AND MIDDLE CAMBRIAN)-Shale, sandstone, and thin-bedded limestone. Shown in section only

$\mathrm{Cb}$ BOLSA QUARTZITE (MIDDLE CAMBRIAN)-Thickbedded quartzite

Ydi DIORITE INTRUSIVE ROCK (PRECAMBRIAN Y)Medium-coarse-grained

Y Y. GRANODIORITE PORPHYRY (PRECAMBRIAN Y)Coarse-grained biotite granodiorite porphyry

s. SILICIFIED ROCK

- CONTACT-Queried where uncertain

- $m$ - MARKER HORIZON

45. 7090

FAULT-Showing dip. Dotted where concealed. Halfarrow shows plunge and approximate strike of slickensides, Queried where uncertain

i NORMAL FAULT-Bar and ball on downthrown side

$\rightleftharpoons$ STRIKE-SLIP FAULT-Arrow couple shows relative movement

$\triangle \quad$ GLIDE FAULT-Open sawteeth on glide mass

A? FAULT ON CROSS SECTION-Arrow couple shows relative movement. $A$, movement away from viewer; T, to ward viewer. Queried where basis for projection is lacking

STRIKE AND DIP OF BEDS

Inclined

Vertical

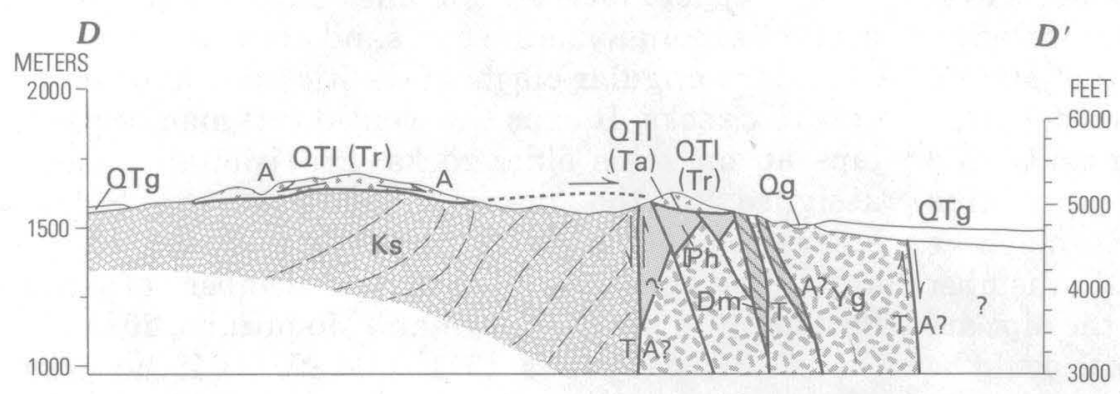

FIGURE 14 (above and facing page).-Geologic map and structure sections of the Winchester Mountains. Geology by Drewes, 1974, and Drewes and C. H. Thorman, 1975. Base from U.S. Geological Survey, 1:31,680, Dragoon (1958), Winchester Mountains (1957); contour interval $50 \mathrm{ft}$. (Figure scale 1:31,680.) 
sedimentary and volcanic rocks. Locally some of these are folded and faulted in a style like that of the allochthonous terrane of southeastern Arizona, and so they are also believed to be allochthonous, although the nearest known traces of major thrust faults lie far to the east or north. The northeastern part of the Ruby quadrangle (pl. 8) is underlain by some of the younger deposits that cover the Cretaceous rocks of the other two areas. Among the covering deposits are rhyolitic and rhyodacitic volcanic units that are generally correlative with the upper Oligocene Grosvenor Hills Volcanics, and with gravel having intercalated olivine basalt that is 13-14 m.y. old.

The Pajarito Mountains occur in the south-central part of the Ruby quadrangle (pl. 8). In this area the Salero Formation is the most widespread unit; it overlies the Fort Crittenden(?) Formation and is overlain by mid-Tertiary volcanic rocks. The Salero Formation is divided into three members, of which a middle member, the welded tuff, is associated with a puzzling rhyodacite porphyry body. Some features of these two units may have a bearing on their origin, although the features are not directly related to Cordilleran tectonics.

In the central part of the area of plate 8 , dacitic volcanic rocks and intercalated epiclastic beds compose the lower member of the Salero. Throughout much of the area underlain by this member, the overlying members are only sparsely preserved beneath the unconformabie cover of rhyodacitic and rhyolitic rocks of Oligocene age. Apparently some movement on a pair of northwesttrending normal faults in this area is of preOligocene age.

Rhyodacite welded tuff forms the middle member of the Salero Formation; it overlies the dacitic volcanic rocks of the lower member and is widespread and thick in the central part of the area. The welded tuff member is a slightly greenish- or brownish-gray, weakly propylitized crystal-lithic tuff. Two features of this member are noteworthy. First, foliation is absent or exceedingly subtle over part of the area underlain by the unit, as indicated by the absence of foliation symbols over part of plate 8 . Second, where foliation is found, it is a flow foliation marked by alined, flattened pumice fragments, and it consistently strikes northwest and dips moderately steeply to the southwest. Inasmuch as the outcrop band of this member is wide, the member apparently is not internally faulted, and the dips are constant, as unreasonably great thickness could be inferred. More likely, the foliation there is not parallel to a tabular mass of welded tuff, as is commonly the case, but was formed by other sorts of flowage, perhaps within a "puddled" mass of accumulated hot ash or, more likely, as foreset beds of a thick ash flow. Conceivably, this kind of situation would keep the rocks hotter for a longer period, thereby perhaps leading to the obliteration of the relict pumice chips of that part of the mass in which no foliation was recognizable. These peculiarities may be related to other features of the associated rhyodacite porphyry unit.

East of the welded tuff member, and apparently laterally gradational with it, is a body of pinkishgray, porphyritic, finely crystalline massive rhyodacite. Although this body is compiled on the map by Wilson, Moore, and Cooper (1969), from reconnaissance study, as a granite stock of Late Cretaceous to Miocene age that intrudes the Cretaceous volcanic rocks, I find support for neither a granitoid texture nor intrusive relations. However, the character and geologic relations of the body of rock remain puzzling. The textural features of the rock are between those of a hypabyssal intrusive and those of an extrusive body and are similar to those of a saccharoidal aplite. The texture also resembles that of some partly extrusive igneous bodies in and near Turkey Creek of the Chiricahua Mountains (Marjaniemi, 1969, and Drewes and Williams, 1973). Perhaps this body was an extrusive dome.

The body contains a few inclusions, tens to hundreds of meters in length, of sandstone thought to be derived from the Bisbee Formation, and one of coarse-grained pink granite, like that of Jurassic(?) stocks. Along the Arizona-Sonora border there is also a larger mass of laminated and intensely indurated rhyolite assigned to the Triassic Mount Wrightson(?) Formation. These rocks presumably came from beneath the massive rhyodacite, and they may lie near the vent or duct that fed the extrusive (or intrusive?) mass. Very likely the enigmas of this rhyodacite body and those of the adjacent welded tuff member of the Salero are related, and possibly they are linked to a Late Cretaceous caldera.

The upper member of the Salero Formation comprises conglomerate and sandstone that contain abundant angular clasts of dacitic and rhyodacitic volcanic rocks. It caps the welded tuff member and laps up on some older rocks. Provisionally, rocks assigned to the upper member of the Salero Formation in the Ruby quadrangle are similar to units assigned to the upper member of that formation in the San Cayetano Mountains, $20 \mathrm{~km}$ to the northeast (Drewes, $1971 \mathrm{~b}$ and 1971c). If the rocks of the upper member are closely related to the underlying volcanic rocks, the presence of epiclastic beds may suggest a site of deposition farther from a 
vent than does the massive igneous rock with large inclusions.

The indications that a source of these Salero rocks lay nearby, perhaps to the east, are intriguing because a strong northwest-trending fault having several phases of movement bounds these rocks on the northeast. Such association of volcanic masses and faults is found elsewhere in southeastern Arizona, as shown on figure 2. If the association is valid here, too, then the exposed part of the fault may only record a fragment of the movement history of a northwest-trending complex fault in the underlying basement rocks.

In the western part of the Pajarito Mountains, reddish-brown conglomerate and sandstone underlie the Salero Formation. The clasts of the conglomerate are subangular to subrounded and comprise much volcanic detritus and some laminated limestone and quartzite that were probably derived from a source in the Bisbee Formation. Bedding dips moderately to steeply northeast. These rocks are correlated with the Fort Crittenden(?) Formation of Late Cretaceous age on the basis of their appearance and known stratigraphic position beneath the Salero and their inferred position above the Bisbee Formation.

Several small areas, mainly hilltops, are underlain by rocks that resemble some found in the Bisbee Formation. These rocks include arkosic sandstone and siltstone, quartzite, black shale, conglomerate, and some laminated limestone. They dip gently to moderately steeply north or northeast, whereas the contact with the Fort Crittenden Formation beneath them is subhorizontal. The contact is concealed but, from the discordance in attitude between the contact and the overlying beds and the inverted stratigraphic sequence of Lower Cretaceous rocks resting upon Upper Cretaceous rocks, the flat-lying contact is inferred to be a thrust fault. The thrust fault occurs only in a small horst, but presumably it extends more widely beneath younger rocks in adja. cent areas.

To assess the likelihood that compressive deformation is more widespread, let me now direct attention to the Ruby mining district in the southwestern part of the Ruby quadrangle (plate 8). Some of the Cretaceous rocks of the Ruby mining district are deformed like other rocks of the allochthonous terrane of southeastern Arizona. The significant structures of the area are northwesttrending intrusive bodies, sparse faults, and a fold. Other faults and folds in the Ruby district may be hidden beneath an extensive cover of younger volcanic rocks to the east and north, or obliterated by intrusive masses to the west. Similar structures probably occur across the Sonoran border to the south.

A belt of Cretaceous sedimentary and volcanic rocks extends from north of the Ruby mine, across the Sonoran border, and a considerable distance farther south. The sedimentary rocks are mainly reddish-brown arkose and arkosic siltstone, as well as some sandstone, black shale, conglomerate, and laminated limestone. These lithologies, and especially the association of the sandstone, shale, and limestone, suggest a correlation with the Bisbee Formation. The abundance of arkosic rocks further suggests a similarity to the facies of Bisbee equivalent rocks found in the Sierrita Mountains, 50 km to the north (Cooper, 1971), and in the Empire Mountains, $80 \mathrm{~km}$ to the northeast (Finnell, 1970). However, the occurrence of volcanic clasts in some conglomerate beds of the Ruby district may indicate the presence of unmapped Upper Cretaceous rocks as well as of the Lower Cretaceous ones. Greenish-gray to brownish-gray volcanic rocks overlie the sedimentary rocks. They are crystal or crystal-lithic rhyodacite(?) welded(?) tuffs that typically contain abundant mica, and they are correlated with the welded tuff member of the Salero Formation. Both sedimentary and volcanic rocks are intensely propylitized and, therefore, primary composition and stratigraphic features are obscured. Near the large intrusive bodies, alteration was especially intense, and in places it occurred with mineralization.

The intrusive rocks comprise a wide textural and compositional assortment, about which only some general features are known, because the intrusives are as altered as their host rocks. Stocks and smaller irregular-shaped intrusive masses are fine grained, porphyritic, or moderately coarse grained; dikes are typically porphyritic, and the kind and abundance of phenocrysts in them vary widely, as described by Knight (1970). Some rocks may be rhyolitic, many are latitic or dacitic, and one larger body is a diorite that resembles the Upper Cretaceous Josephine Canyon Diorite of the San Cayetano Mountains, 30 $\mathrm{km}$ to the northeast (Drewes, 1976b). The assortment of intrusive rocks and their association with widespread alteration and mineralization suggest that most or all of them are of late Cordilleran age (latest Cretaceous or Paleocene).

The rocks of the Ruby mining district have a northwest-trending structural grain, best illustrated on the Geologic map of Arizona (Wilson and others, 1969); detailed structural features are mostly obscured by the many intrusive masses and associated alteration. Within the area of plate 8 the northwest-trending grain is marked by the 
orientation of stocks and faults. Bedding mostly dips south to southwest; the extent and regularity of the attitudes and the lack of internal stratigraphic control in the map units may indicate the presence of many unrecognized faults.

In the southwestern corner of the map area, where alteration was weakest, the Bisbee Formation is warped into a moderately tight syncline. The amplitude of the fold is many tens of meters; its axis trends northwest and is subhorizontal. Similar folds probably occur immediately south of this part of the Sonoran border. Nearby, unfolded northwesttrending dikes cut the folded rocks, and a major fault also truncates it. At least one movement on a segment of this fault occurred during or after the Oligocene, for the cover of young volcanic rocks is faulted against the older rocks.

Meager as this structural evidence is, it is compatible with that of adjacent mountain ranges. The folding was a typical response to northeastwardoriented compression of Late Cretaceous (postSalero, pre-stock emplacement) age. Subsequently, the area was extensively intruded, altered, and in places mineralized. Together, these events are characteristic of the Cordilleran orogeny. The northwest-trending structural grain may reflect structural control by one or more faults of the set of complex faults in the basement. As happened elsewhere, magma movement was guided by these faults. Some fault movement is late Cordilleran or early post-Cordilleran, and in places movement recurred in middle or late Tertiary time.

The third studied area in the Ruby quadrangle is a small one on the east flank of the Atascosa Mountains (pl. 8), where the age of young gravel or conglomerate deposits and faulting was determined. In this area, as at Nogales (Simons, 1974), there is an older major unit of tilted gravel and conglomerate, the Nogales Formation, and younger gravel units that cap a pediment, rest on stream terraces, or lie along watercourses. The Nogales Formation is a slightly indurated, pale-yellowish-brown to lightbrownish-gray unit of moderately well-bedded sand, pebble gravel, and cobble gravel. A nearly white unit of rhyolite tuff and tuffaceous sandstone is intercalated in the formation at an undetermined stratigraphic position. An olivine basalt lava flow occurs a few tens of meters higher. Similar basalt is found in the southeast part of plate 8, as well as near Nogales (Simons, 1974). A pyroxene concentrate from this basalt was dated as late Miocene, 13-14 m.y. old (Marvin and others, 1973).

In the northeast part of plate 8 the Nogales Formation is cut by north-trending normal faults, one of which lies along a segment of the mountain front on the west. The eastern blocks, or basin sides of the main faults, are down dropped. The younger pediment gravels, of Pleistocene and Pliocene age, unconformably cap the Nogales Formation and most of the faults within the Nogales. The local evidence, then, suggests that the basin in which the Santa Cruz River flows was formed during Miocene and Pliocene time. Faults along the east side of the basin, or graben, have a record of movements both younger and older (Drewes, 1972a) than that along the Atascosa Mountains, so apparently the graben was developed over a considerable span of relatively recent time. Possibly the main fault at the mountain front, below the present level of exposure, provided the ducts for the egress of the basalt magma; movement on them may have occurred coevally with the volcanism.

\section{SOUTHERN MULE MOUNTAINS}

My own mapping of a part of the southeastern end of the Mule Mountains near Gold Hill and Glance Creek has confirmed the accuracy of the distribution of most formations and faults shown by Hayes and Landis (1964). A portion of their map, presented on figure 15 , is modified to include some refinements and new observations along the major faults. A few reinterpretations are noteworthy. (1) A reported thrust fault is seen to dip steeply, rather than gently; it occurs in segments offset from each other by younger faults. (2) A small rhyodacite porphyry plug probably cuts a major fault rather than being cut by the fault. (3) Horquilla Limestone is not believed to be exposed beneath a large expanse of Glance Conglomerate; instead, the reported limestone is seen to consist of clastic blocks in fanglomerate boulder trains and of some small megabreccia landslide deposits intercalated in the conglomerate. A large reverse fault that extends through the vast area of the Glance Conglomerate accounts for a substantial amount of repetition of strata.

In the area of figure 15 a northwest-trending zone of structural blocks, mainly of Paleozoic rocks, separates two terranes underlain by rocks of the Lower Cretaceous Bisbee Group. The formations were described in detail by Hayes and Landis (1965) and by Hayes (1970a); therefore, only a little additional detail, pertinent to the interpretation of structural features in the Bisbee Group, is presented below. The faults that bound the blocks of Paleozoic rocks were inferred by Hayes and Landis (1964, structure sections $C-C^{\prime}$ and $D-D^{\prime}$ ) to be an older lowangle thrust fault on the northeast and a younger high-angle normal fault on the southwest. The traces 

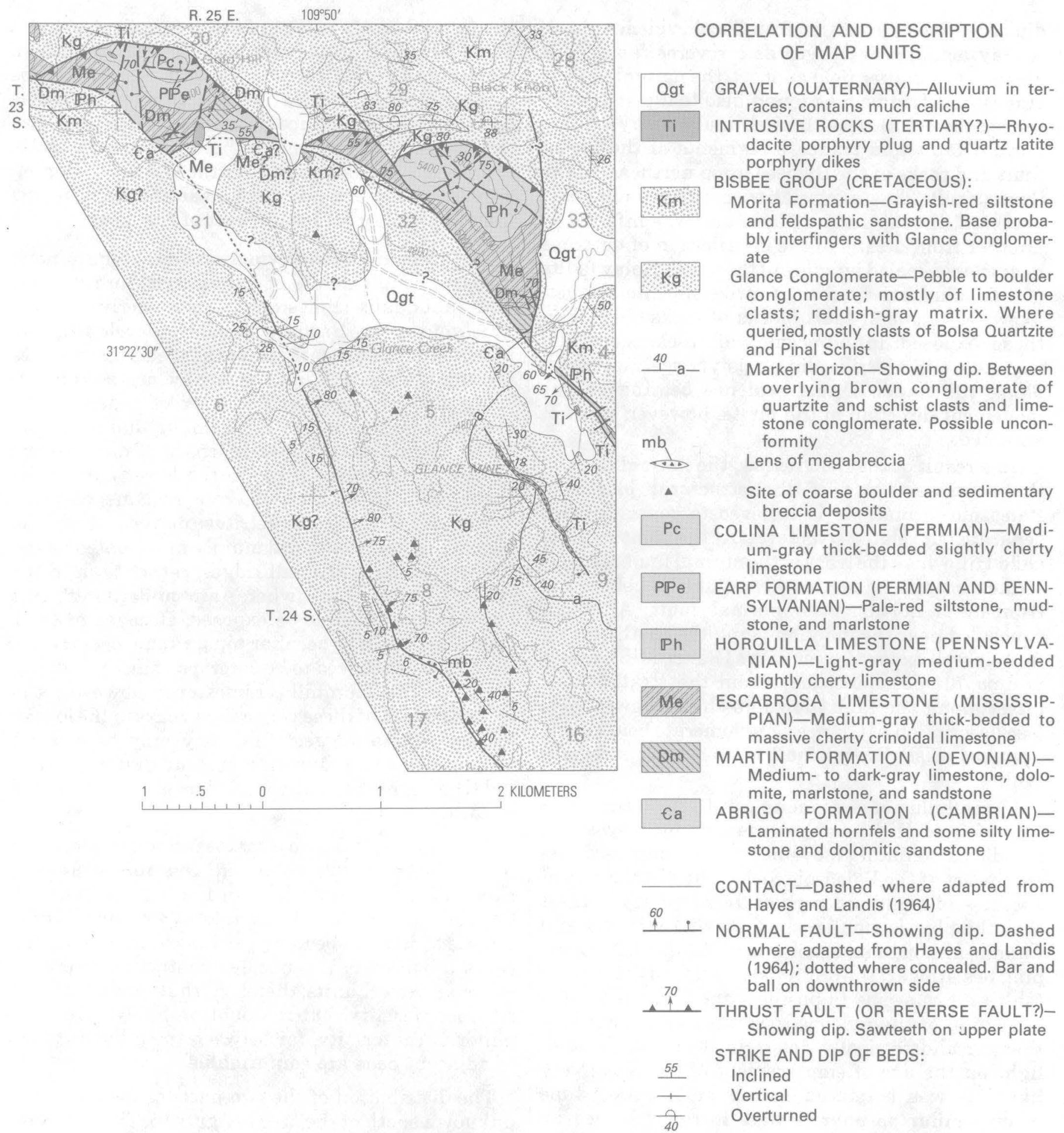

FTGURE 15.-Geologic map of part of the southern Mule Mountains near Gold Hill and Glance Creek. Geology by Hayes and Landis, 1964, modified by Drewes, 1972. Base from U.S. Geological Survey, 1:62,500, Bisbee (1958); contour interval $40 \mathrm{ft}$. (Figure scale 1:48,000.)

of these faults are gently arcuate, concave to the southwest. In detail, though, the normal fault is shown to make an abrupt change in strike south of
Gold Hill, giving the fault trace a cuspate appearance.

The thrust fault of Hayes and Landis was found to 
dip $55^{\circ}-80^{\circ}$ southwest, so from local evidence alone, it may actually be viewed as a reverse fault. With somewhat scantier field support, the normal fault of Hayes and Landis was found also to dip steeply to the southwest. Several branch faults splay off this normal fault and truncate segments of the thrust fault and rocks of the Bisbee Group northeast of the thrust fault. This age relation between faults was observed directly in one place, and was inferred in another from details of the distribution of outcrops near the concealed juncture of the faults. Splay faults of this kind are typical of strike-slip fault zones; likewise, a zone of fault blocks of rocks older than those exposed in adjacent wall rocks generally suggests either strike-slip or polyphase movement along the faults. Direct evidence bearing on the movement direction of the faults, however, was not obtained.

As a result of the field review, the normal fault on the southwest side of the structural blocks of Paleozoic formations is believed to consist of two separate but related structures. At the point south of Gold Hill where the trace of the normal fault changes strike abruptly, a southwestern fault is believed to truncate a northeastern normal fault. Although concealed near the junction point, the southwestern fault is well exposed west of the Glance Mine, where it dips $70^{\circ}-80^{\circ}$ northeast. From the stratigraphic offset along the fault, down on the southwest side (see description of Glance Conglomerate below), this segment of southwest fault is seen to be a reverse fault.

A small plug of rhyodacite porphyry on the south side of Gold Hill has been mapped by Hayes and Landis as predating movement on the normal faults southwest of the Paleozoic rocks. The distribution of sparse and small outcrops of the porphyry suggest that the plug is smaller than shown by Hayes and Landis, although its detritus is widespread. Also, the plug lies athwart the projected position of the normal fault and so seems to postdate the fault. Intensive alteration of the igneous rock has made it unlikely that a radiometrically determined age would shed light on the age of emplacement of the plug. Very likely, it was emplaced during mid-Tertiary time when similar porphyries were intruded in nearby areas. The normal fault, then, was active during the interval of mid-Cretaceous to mid-Tertiary.

The Glance Conglomerate, basal unit of the Bisbee Group, is the most widespread rock shown in the area of figure 15; in fact, its type locality is the hill on which the Glance Mine is located (Hayes, 1970a, p. A-12). Hayes provided a reference section near Bisbee because the type locality provides no top to the formation. My review of the area indicates that it also does not provide a base to the formation. Nevertheless, the terrane at and near the type locality is more informative than that in most areas underlain by the Glance Conglomerate, because two subdivisions are recognized there. The conglomerate forms a homoclinally northeastward dipping sequence that extends from near the mine to the faults northeast and southwest of the mine.

The lower unit of the formation, west of the mine, is a coarse conglomerate of light-grayish-brown color and abundant limestone clasts derived from Paleozoic rocks. Bedding is poorly developed, and many outcrops are so massive that bedding attitudes are unobtainable. Clasts typically are angular to subrounded. Fanglomerate lenses of nearly monomyctic angular blocks $0.3-1 \mathrm{~m}$ in diameter and a few megabreccia landslide lenses of monomyctic blocks 2-7 $\mathrm{m}$ across occur in the lower part of the lower unit. These fanglomerate and megabreccia lenses are largely of detritus derived from the Horquilla Limestone, and mainly are situated on the crests of spurs and small ridges, rather than in the intervening gullies, where an underlying unit normally would first be exposed. Because of their clastic texture and peculiar topographic occurrence, they are not believed to be outcrops of an underlying sheet of the Horquilla Limestone; however, the concentration of these very coarse rocks in the lowest exposed strata suggest that they may be a basal conglomerate to a conglomerate, and that the base of the Glance, perhaps upon the Horquilla, lies not far below the surface.

The upper unit is also a coarse conglomerate, but it has a darker brown color and contains abundant clasts of Bolsa Quartzite. On the hill south of the Glance Mine, W. L. Bilodeau (oral commun., 1975) reported diverse bedding attitudes in unsheared rocks adjacent to a concealed contact between the upper and lower units; therefore, that contact may be an unconformity, but it would probably be only a minor unconformity, for between the hills attitudes of adjacent beds are conformable.

The distribution of the two parts of the Glance is unknown south of the area of figure 15. The two units may prove to be of only local stratigraphic or facies significance. Conceivably, however, the upper unit is a markedly younger conglomerate, such as a basal part of the Upper Cretaceous Cabullona Group-of Mexico, which is extensively exposed $20 \mathrm{~km}$ to the south in Sonora (Taliaferro, 1933), or the basal part of the Fort Crittenden Formation, $90 \mathrm{~km}$ to the northwest (Drewes, 1971c). 
As a result of the field review, the fault zone of the southern part of the Mule Mountains and the very thick, coarse deposits of Glance Conglomerate are inferred to be genetically related. The coarse character of the Glance suggests that a topographically high area lay nearby during or just before Early Cretaceous time. Ransome (1904) and Hayes (1970a) have proposed that such an upland existed in the area now occupied by the main part of the Mule Mountains to the northwest, and that it was genetically related to the emplacement of the Juniper Flat stock, of Jurassic age, and to movement on the Dividend fault (Hayes and Landis, 1964). In essence, the entire Paleozoic sequence was eroded from the northeastern uplifted block, and the resulting detritus was in part deposited as the prism of conglomerate and fanglomerate on the southwestern or downthrown block. In this paleogeographic framework the thick, coarse deposits of Glance in the area of figure 15 accumulated at the foot of an upfaulted highland northeast of the fault zone at Gold Hill. Renewed movement on this fault zone occurred at least once during Late Cretaceous or early Tertiary time, probably with a combination of lateral and vertical displacement. Several northtrending strands of the fault splayed off the main fault zone near its change in trend, as shown by the crescentic trace of the fault zone. The splay fault pattern north of Glance Creek and the thin slices of Horquilla Limestone south of the creek suggest that strike-slip movement occurred along the fault zone. The thrust fault (or reverse fault?) is probably a local feature related to the multiphase movement of blocks of Paleozoic rocks caught along the fault zone.

A similar situation is believed to occur $10 \mathrm{~km}$ to the west, where the probable continuation of the fault zone at Gold Hill reappears from beneath gravels and breaks into several strands, such as the Abrigo fault and Bisbee West fault (Hayes and Landis, 1964). The many unnamed normal faults that make a trellis pattern between the Abrigo-Gold Hill fault zone and the Dividend fault may have developed in response to local tensional stress between two sigmoidally warped strands of a master fault, along which there was left-lateral movement. These master faults have been loci of fluid movement, first of the magma that was emplaced in part along the Dividend fault as the Juniper Flat stock north of Bisbee, then of the small Sacramento porphyry stock at Bisbee, and of mineralizing fluids in and around Bisbee, and finally of the plugs and dikes of rhyodacite and quartz latite porphyry along the Abrigo-Gold Hill fault zone.

\section{NORTHERN TUMACACORI MOUNTAINS}

The extreme northern end of the Tumacacori Mountains is underlain by a Jurassic granodiorite stock that contains a swarm of intensely contact metamorphosed inclusions and roof pendants(?), and by wall rocks of Triassic and Paleozoic formations (fig. 16). The pre-stock rocks contain remnants of faults, possibly including thrust faults. The stock is cut by northeast-trending normal faults, at least one of which is a range-front fault of Pliocene or Pleistocene age.

The Amado stock, here named for the community of that name located $8 \mathrm{~km}$ to the east, comprises mainly medium-dark-gray granodiorite of massive appearance, some pinkish-gray quartz monzonite(?), and small aplite dikes and pods. Under the microscope the granodiorite is seen to have a grain size of 4-8 $\mathrm{mm}$ and an assemblage of plagioclase, quartz, orthoclase, biotite, and hornblende. Most minerals are sufficiently altered that they are not desirable for radiometric dating, but essentially unchloritized biotite collected far away from the abundant inclusions was dated at 145 m.y. (R. F. Marvin, H. H. Mehnert, and Violet Merrit, written commun., 1975). According to Marvin, Paul Damon has also dated the stock at 148 m.y., using samples from a site shown queried on figure 16; the location of this site is less precisely known, as it was reconstructed from geographic coordinates.

The host rocks and inclusions of the stock are hornfels, marble, and metaquartzite, which are interspersed with skarn zones and iron-manganese(?) oxide-impregnated rocks. Despite the metamorphism, many lithologies or lithologic associations are recognizable as derived from formations of Cambrian to Pennsylvania ages; these are mainly dolomite marble, limestone marble, and coarsegrained metaquartzite. A rock assemblage of conglomerate, meta-arkosic sandstone and siltstone, and some red beds and carbonate rock had previously been correlated with the Bisbee Group (Cunningham, 1964), but newly obtained radiometric dates show the rocks must be older; thus, they could correlate with the Gardner Canyon Formation of Triassic age.

Most of the inclusions or roof pendants have a wide array of attitudes, which indicates block rotation within a magma. The largest mass of invaded rock, probably part of the wall rock, includes parts of several of the sedimentary formations, and in places these are faulted against each other. While faulting so close to a stock may simply reflect adjustment of the host rocks to forcefully emplaced magma, it is interesting to note that some faults are low-angle, 


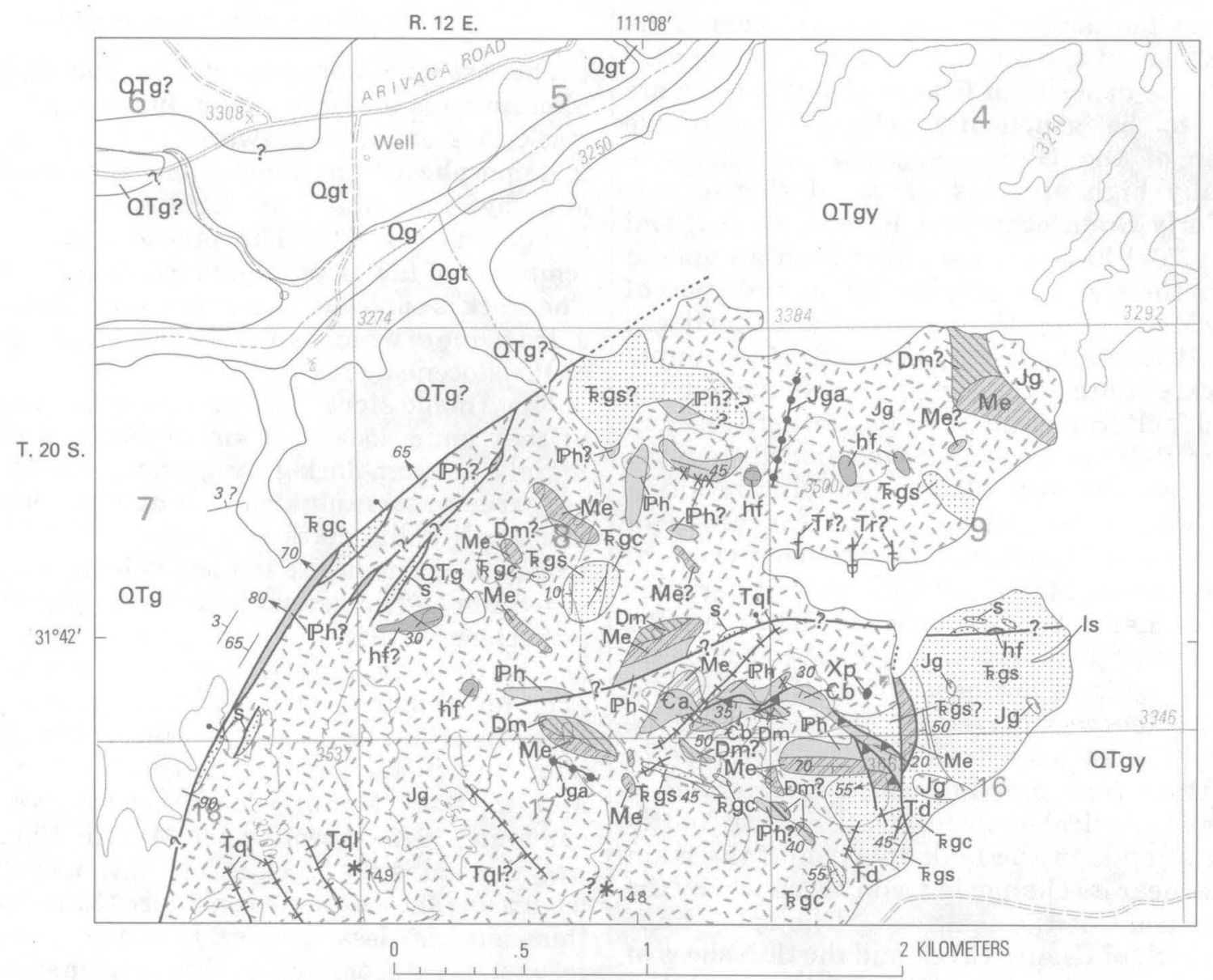

FIGURE 16 (above and right).-Geologic map of the northern end of the Tumacacori Mountains. Geology by Drewes, 1967, 1974. Base from U.S. Geological Survey, 1:62,500, Tubac (1957); contour interval 50 fí. (Figure scale approximately $1: 31,680$.)

bedding-parallel structures that place older rocks upon younger ones. Perhaps they are remnants of a prestock deformation.

One bit of negative information is also noteworthy when the area of figure 16 is placed in geographic context with the major structural features of the Sierrita Mountains (Drewes, 1980). A major northwest-trending, steeply inclined fault zone lies along the west flank of those mountains and appears to end abruptly in line with a northeast-trending complex fault, the Sierrita line. Some aspects of the interpretation of the northwest-trending fault depend on a more complete knowledge of where it may continue to the southeast, if indeed it does so. Much of the critical area of the southwestern part of the Sierrita Mountains is covered by late Cordilleran or younger rocks and so provides no evidence. This area at the northern end of the Tumacacori Mountains is in line with the northwest-trending fault zone, and it contains no signs of northwesttrending faults of Cordilleran age.

\section{TUCSON MOUNTAINS}

Some of the older rocks on the southwest flank of the Tucson Mountains are folded and faulted in a style like that of rocks deformed by regionally applied, northeast-directed compression. This deformation was of Late Cretaceous age, as it postdated the deposition of the late Early Cretaceous Bisbee Formation (locally known equivalent in Tucson Mountains is Amole Arkose of Brown, 1939) and some younger rocks (possibly the Fort Crittenden Formation of Late Cretaceous age) but predated the unconformably overlying volcanic rocks of latest Cretaceous age (65-70 m.y.). The significance of these deformed rocks has been difficult to assess, because they occur in several small, widely dispersed areas and because the ages of many rocks were inadequately known until recently. Furthermore, a sheet of volcaniclastic rock containing abundant large inclusions of exotic rocks attracted much of the geologic effort in these mountains. 
CORRELATION OF MAP UNITS
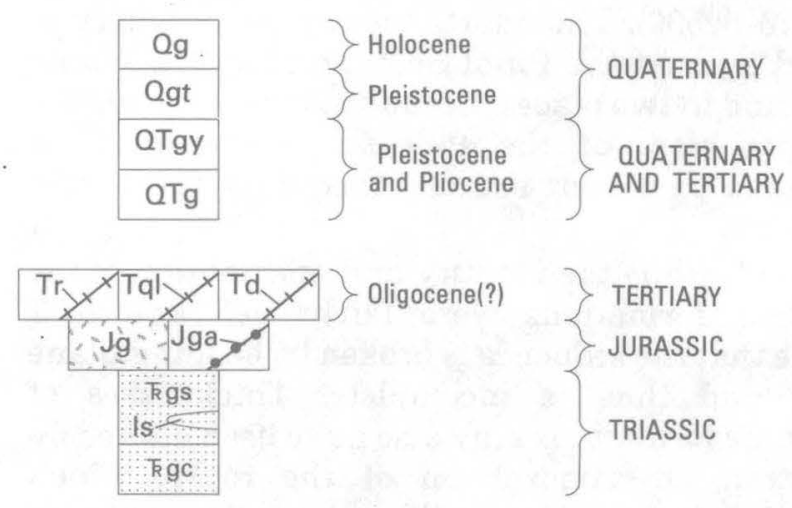

\section{Oligocene(?)}

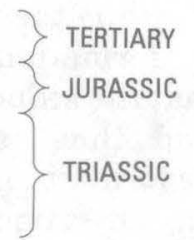

\begin{tabular}{|c|}
\hline Ph \\
\hline Ale \\
\hline$D h$ \\
\hline$\epsilon a$ \\
\hline$\epsilon b$ \\
\hline
\end{tabular}

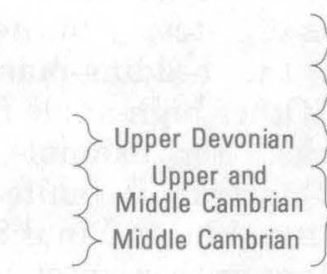

PENNSYLVANIAN MISSISSIPPIAN DEVONIAN CAMBRIAN $\mathrm{Xp} \bullet$ PRECAMBRIAN

\section{CONTACT}

FAULT-Showing dip, inclined and vertical. Dotted where concealed. Queried where uncertain. Bar and ball on downthrown side

a A A THUST FAULT-Sawteeth on upper plate

\section{STRIKE AND DIP OF BEDS:} Inclined Vertical

* 149 SAMPLE SITE-Showing age of rock in m.y. Queried where precise locality uncertain

$x \quad$ PROSPECT-Shows trace of copper mineralization

The rocks of the Tucson Mountains range in age from Precambrian to Miocene, and still younger deposits of the adjacent basins lap low onto their flanks. An older suite of rocks consists of sparsely exposed Precambrian schist and granodiorite porphyry, and an incomplete sequence of Paleozoic and Mesozoic rocks. Most widespread of the older suite of rocks is a thick sequence of arkosic rocks of Early Cretaceous age and some overlying conglomerate of possible Late Cretaceous age. These rocks were thrust faulted, folded, and normal faulted, and then 70-75 m.y. ago were intruded and metamorphosed by the Amole stock. A younger suite of rocks lies unconformably upon the older ones and includes two volcaniclastic formations of late Late Cretaceous age and Tertiary volcanic units with intercalated clastic units. Small intrusive bodies of Mesozoic and Cenozoic ages are scattered through-

\section{DESCRIPTION OF MAP UNITS}

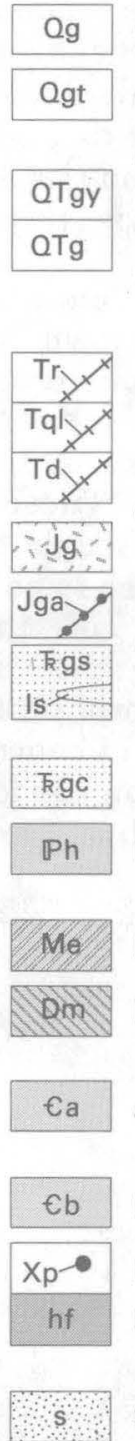

GRAVEL AND SAND (HOLOCENE)—Alluvium along watercourses

GRAVEL AND SAND (PLEISTOCENE)-Alluvium on low terraces

GRAVEL (PLEISTOCENE AND PLIOCENE):

Younger deposits-Mainly on pediment

Older deposits-On pediment and in basin. May include deposits as old as the Nogales Formation of Pliocene and Miocene age

PORPHYRY DIKES (OLIGOCENE?):

Rhyolite-Phenocrysts include quartz and a feldspar

Quartz latite-Phenocrysts include two feldspars

Dacite-Phenocrysts include much amphibole

GRANITOID ROCK (JURASSIC):

Granodiorite-Includes some dioritic rock and small xenoliths of hornfels

Aplite dikes

GARDNER CANYON(?) FORMATION (TRIASSIC):

Sandstone-Hornfelsed arkosic sandstone and siltstone, and redbeds; Is - Limestone, metamorphosed

Conglomerate-Hornfelsed and marmorized conglomerate, mainly from lower part of formation

HOROUILLA LIMESTONE (PENNSYLVANIAN)-Finegrained thin units of cherty marble and intercalated hornfelsed siltstone

ESCABROSA LIMESTONE (MISSISSIPPIAN)Coarse-grained nearly-white massive marble

MARTIN FORMATION (UPPER DEVONIAN)-Brown dolomite marble, gray limestone, marble, and hornfels

ABRIGO FORMATION (UPPER AND MIDDLE CAMBRIAN)-Thin-bedded hornfelsed siltstone and quartzite

BOLSA QUARTZITE (MIDDLE CAMBRIAN)-Thickbedded metaquartzite

PINAL SCHIST (PRECAMBRIAN X)—Gray mica schist

HORNFELS - Intensely altered rock; includes some marble. Probably derived from the Paleozoic or Mesozoic formations

out the range, and include a prominent dike swarm across the middle of the range. Typically the older rocks underlie the southwest side of the range and the younger ones the crest and east side. The rocks form a gently northeastward dipping homoclinal block.

Geologic mapping of part of the Tucson Mountains provides some new observations on the older rocks and the lowest of the younger rocks, and these observations lead to new inferences on certain structures and on the geologic history during the Cordilleran orogeny. Most of the new observations are about rocks and structures shown in the area of plate 9, but a few are offered that concern the Twin Peaks (shown as Picacho de la Calera on older maps) and the site of a large limestone quarry, which lies 8 $\mathrm{km}$ north of the west end of plate 9. Previously published geologic maps commonly show outdated 
stratigraphy and age designations or abandoned structural interpretations, show only very small areas, or use an inadequate topographic base. Nevertheless, considerable progress in understanding the geology of the area has been made through the contributions of Brown (1939), Kinnison (1959), Mayo (1968 and 1971), and Mayo and Davis (1976).

At Twin Peaks, a metamorphosed Paleozoic sequence overlies basement rocks, as shown by Brown (1939). However, two new interpretations are offered in figure 17, and one of them provides clues to the structural condition of at least some of the unexposed older rocks beneath the Tucson Mountains. First, the granite previously thought to be of Tertiary or Cretaceous age is now seen to be a porphyritic quartz monzonite typical of the Precambrian basement. This age reassignment is based on lithologic correlation of the porphyritic quartz monzonite with other granitic rock of known Precambrian age and on a potassium-argon age for muscovite obtained from a drill hole south of Twin
Peaks (P. E. Damon, oral commun., 1978; NSF Grant EAR 76-02590). The quartz monzonite porphyry is faulted against the Pinal Schist and the Paleozoic rocks, and in two places the fault is vertical. Thus the metamorphism of the Paleozoic rocks must be attributed to a heat source other than the quartz monzonite.

Second, while the identity and distribution of the Paleozoic formations were fairly well known, I believe that the sequence is broken by bedding-plane faults and thus is incomplete. Thicknesses of carbonate formations may also have been altered by the strong metamorphism of the rocks, which typically are marbles rather than limestone or dolomite. The rocks dip steeply to the northeast in most places, and the bedding-plane faults are similarly oriented. Other high-angle faults also cut the Paleozoic rocks. For example, the Middle Cambrian Bolsa Quartzite is faulted against (or perhaps on?) the Precambrian Pinal Schist, for the bedding is discordant with respect to the contact between the formations. In the saddle between the

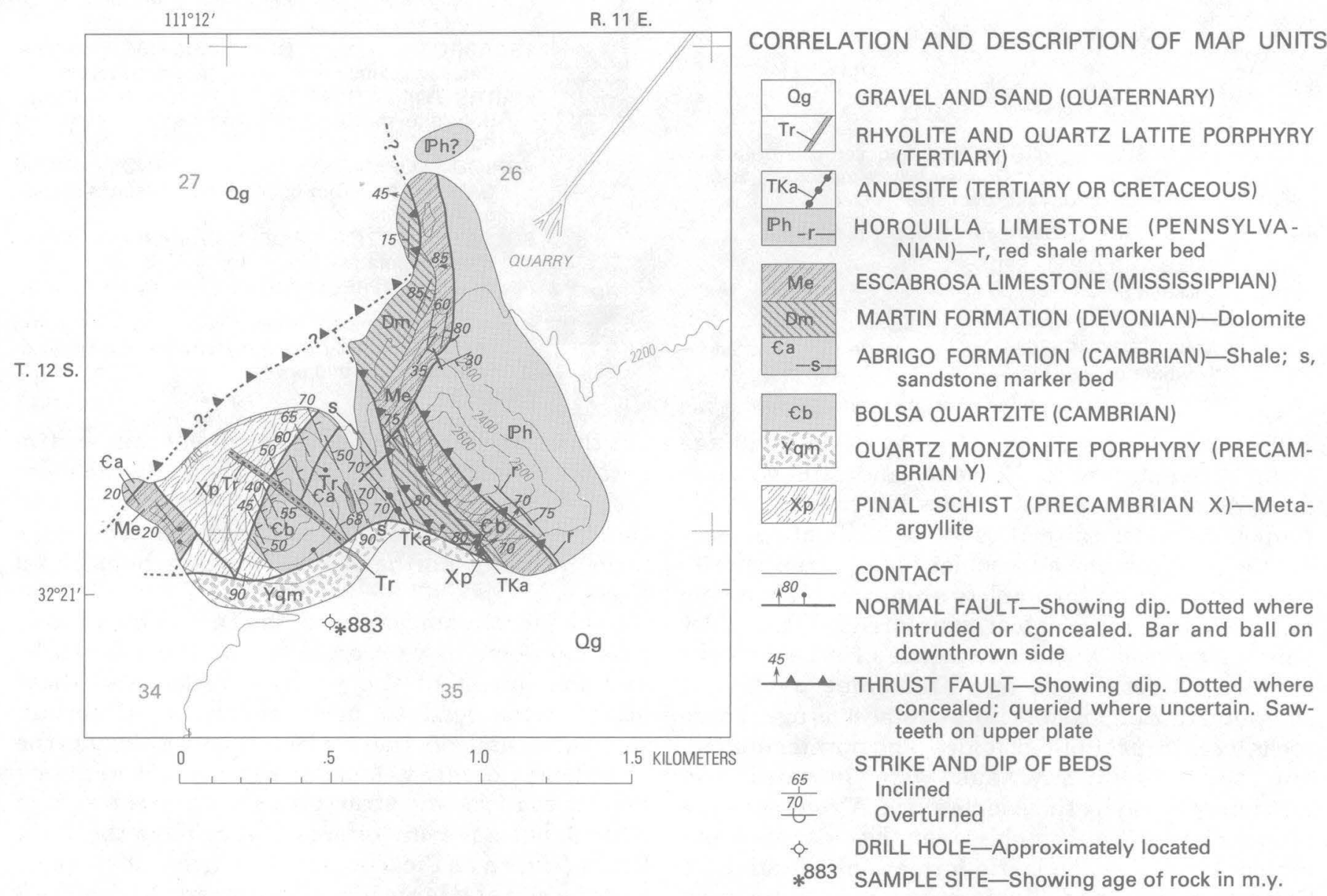

FIGURE 17.-Geologic map of part of the Tucson Mountains near Twin Peaks. Geology by Drewes, 1975. Base from U.S. Geological Survey, 1:24,000, Avra, 1968; contour interval $20 \mathrm{ft}$. (Figure scale 1:24,000.) 
two hills of Twin Peaks, a sandstone marker bed within the Middle and Upper Cambrian Abrigo Formation is offset by a fault that does not cross the adjacent contact with the Upper Devonian Martin Formation. Such a fault is likely to be a disharmonic fault abutting a bedding-plane fault that follows the lithologic break between shaly beds of the Abrigo and dolomite marble of the Martin. A similar relation was described in the section of this paper on the Tombstone Hills. The Martin Formation appears to be abnormally thin, and the postulated beddingplane fault at its base and other effects of metamorphism could account for this condition. Also, a bedding-plane fault that dips $70^{\circ}$ northeast is exposed in the upper part of the formation in a quarry on the south side of the hill, and might account for some thinning. Finally, thin units of reddish-gray shale or argillite occur at and slightly above the base of marmorized Pennsylvanian Horquilla Limestone, rather than well up in the formation. There being no signs of a disconformity replacing the lower part of the Horquilla, the juxtaposition of the upper part of the Horquilla on the coarsely crystalline marble of the Mississippian Escabrosa Limestone is probably due to beddingplane faulting. Most of these faults are concealed, or recrystallization has obliterated direct evidence of their presence, but slivers of rocks out of place with respect to adjacent wall rocks are present in the quarry, and this indirect evidence suggests that the formations are incomplete, owing to several beddingplane faults. This situation is typical of many of the abundantly thrust-faulted ranges, such as the Santa Rita and Dragoon Mountains.

The rocks in the hill west of the Sus picnic area in the northwestern part of the area of plate 9 may also be thrust faulted. The rocks comprise several formations of Pennsylvanian and Permian ages and one of early Mesozoic age, all of which were faulted and then contact metamorphosed by the adjacent Amole stock, dated at 71-75 m.y. by Damon. The identity and order of the stacking of the metasedimentary rocks is the basis for my structural interpretations near the picnic area. A northtrending normal fault separates the metasedimentary rocks into two masses, the western one relatively little deformed, but the eastern one more intensely jumbled. A fine-grained and mostly lightcolored metaquartzite that is found high on the north side of the hill of the eastern mass is probably part of the Permian Scherrer Formation. This quartzite forms a sheet that lies anomalously above $\cdot a$ finegrained, light-gray marmorized limestone, most likely part of the Horquilla Limestone, and anomalously beneath a lenticular mass of very coarsely crystalline marble probably formed from Escabrosa Limestone. Based on these formation identifications, the quartzite is inferred to be separated from the carbonate units by low-angle faults. On the south side of the hill, a volcanic-clast conglomerate and sandstone unit caps the Paleozoic rocks. The bedding of the clastic cap dips steeply to the southwest and abuts the concealed and more gently dipping basal contact of the unit. Such structural discordance may also indicate faulting. Bedding-plane or low-angle faults such as those inferred near the Sus picnic area commonly are interpreted to be thrust faults; here there is an implication that some kind of compressive deformation occurred before emplacement of the Amole stock.

Brown Mountain (sec. 7, T. 14 S., R. 12 E.), also known on older maps as the Piedmontite Hills, and the surrounding area are underlain by rocks less metamorphosed and differently deformed than those in the Twin Peaks or Sus areas. I interpret Brown Mountain to be part of a horst, 0.5-1 km wide, of Triassic and Jurassic sedimentary and subordinate amounts of ingeous rocks, bordered on three sides by sedimentary rocks of Cretaceous age. The northwestward extension of the horst is interpreted to be cut by the Amole stock. The two northwest-trending normal faults bounding the horst are exposed at Brown Mountain, but the southeastern end of the block is concealed beneath pediment gravel near Old Tucson. Only the younger rocks are found beyond the gravel cover just off plate 9; these were shown by Brown (1939) and Roger Ashley (written commun., 1975).

The rocks of the horst include an underlying sequence of the Recreation Red Beds that was once accepted as Cretaceous but now (Hayes and Drewes, 1968) is interpreted to be Triassic(?). The formation consists largely of pale-red to moderatered mudstone, siltstone, and fine-grained sandstone, in which are intercalated pale-red to yellowish-brown units of coarser sandstone and grit conglomerate to pebble conglomerate. The rocks are cut by a coarsely porphyritic andesite dike that is dated radiometrically by Damon as 150 m.y. The red beds are probably correlative with the Gardner Canyon Formation, which is dated radiometrically as 192 m.y. in the Santa Rita Mountains (Drewes, 1971c) and dated geologically as older than the Canelo Hills Volcanics of 173 m.y. age (Hayes, Simons, and Raup, 1965). The Tascuela Red Beds and Rodolfo Formation in the Sierrita Mountains (Cooper, 1971) are also probably correlative with the Recreation Red Beds. The red beds of the horst are overlain by an 
unnamed brownish-gray sequence of conglomerate and sandstone, and a rhyolitic welded tuff. Volcanic clasts are common in the conglomerate, and the sandstones are sub-graywackes. The tuff breccia is a pinkish-gray, strongly indurated unit found at the highest known part of the sequence in Brown Mountain. It may be correlative with the Canelo Hills Volcanics of Triassic and Jurassic age. Several dikelets and a larger, irregular-shaped mass of rhyolite porphyry, at least some of which has a shard texture, intrude the sequence and resemble the welded tuff sufficiently that they may be genetically related to the tuff.

The rocks of the horst dip generally northeast to southeast $10^{\circ}-30^{\circ}$. Two small northwest-trending open folds occur on the northwest end of Brown Mountain. A dome reported by Mayo and Davis (1976), but not shown on their maps, was not recognized in the horst.

Most of the rocks adjacent to the horst at Brown Mountain are shown on older maps as the Amole Arkose and herein as the Bisbee Formation. Inasmuch as Hayes (1970b) showed that these rocks, of late Early Cretaceous age, probably accumulated in a single major basin of deposition, the regionally applied nomenclature is preferred to the local one, which may be more appropriate to local facies or members. The Bisbee Formation near Brown Mountain consists of alternating medium-gray to yellowish-brown siltstone and yellowish-brown arkosic sandstone units.

The base of the arkosic part of the Bisbee is everywhere covered or faulted out, but Glance Conglomerate Member is probably present, for it occurs as large clasts in some younger rocks. Lentils of pebble conglomerate occur low in sandstone units of the lower part of the formation. Near the middle of the formation is a unit a few hundred meters thick in which are found thin beds of fine-grained, laminated limestone. This zone may be equivalent to parts of the Apache Canyon and Shellenberger Canyon Formations of the Bisbee Group in the Empire Mountains (Finnell, 1970), and it may occur at the horizon of the Mural Limestone in the type area of the Bisbee. Some of the intercalated sandstone units of the upper part of the Bisbee are fairly quartzose and strongly indurated, and they resemble the sandstone units of the Turney Ranch Formation of the Empire Mountains.

The rocks of the Bisbee Formation are abundantly and regularly folded. Fold axes lie subhorizontal and trend $\mathrm{N} .30^{\circ} \mathrm{W}$. The folds are mostly moderately tight to open, and are upright or inclined to the northeast. Fold amplitudes commonly are a few tens or hundreds of meters. The folds seem to die out to the north near the Amole stock, but they extend not only northeast of the horst, where they were studied by Mayo and Davis (1976), but also southeast of the horst, on the hill south and southeast of Old Tucson. I agree with Mayo and Davis that these folds probably formed as disharmonic features above a flat-lying fault and that they could indicate northeastward transport; however, the timing and the mechanism they proposed are not supported by the geology of the area. Sliding the crumpled rocks off a dome that was raised 150 m.y. ago, as they suggest, seems unlikely because no dome of that age is recorded by the younger sediments or by the pre-150-m.y.-old rocks themselves. (Indeed, the rocks of the horst are more likely of Triassic than of Jurassic age.) The uplifted block, or horst, is probably too small to have provided the impetus for extensive sliding. Finally, inasmuch as the uplifted block does not extend beyond the gravel covered area of Old Tucson but the folds do, there can scarcely be a genetic relation between them. Stated in a different way, had the rocks slid off the only structurally high block in the area, they should have moved radially off that block and thus in the area south and east of Old Tucson their axes should be striking northeast instead of northwest. From the available evidence, it is even likely that the development of the horst postdates the folding.

Some clastic rocks about $4 \mathrm{~km}$ north of Old Tucson may be younger than the Bisbee Formation and are the youngest of the older deformed rocks of the Tucson Mountains. They consist of volcanic-clast conglomerate and of arkosic sandstone and siltstone that are much like rocks of the Bisbee. Similar rocks in other ranges occur in the Fort Crittenden Formation of Late Cretaceous age. The volcanic-clast conglomerates appear to be faulted against the typical Bisbee rocks, and they also dip steeply, and therefore likely are part of the older deformed suite of rocks.

A few features of the younger or postdeformation rocks of the crest and northeast flank of the range are also noteworthy. The lowest formation of this suite is the Silver Bell Formation (Wood, 1959), which forms a sheet at least $100 \mathrm{~m}$ thick that lies unconformably upon the folded rocks of the older suite. This formation is wholly fragmental and consists largely of dacitic volcanic material. The dacitic rock is mostly bluish- to greenish-gray and is fairly friable. A few parts of the formation appear to be tuffaceous, and others contain epiclastic beds.

Above all, the Silver Bell Formation is remarkable for its abundant and large inclusions of exotic blocks-blocks of rock unlike that of the dacitic host. 
While most of these blocks are $1-10 \mathrm{~m}$ in diameter or even smaller, some of them are a few tens of meters long and a few exceed $100 \mathrm{~m}$ in length. Many blocks are more or less equidimensional and others are tabular or elongate. A few large blocks, particularly near the Amole stock, have sheared surfaces against the host rock, but these features seem not to extend far into the host rock. Internally the blocks are coherent masses or aggregates of shattered blocks with some penetration by the host material.

The blocks consist of a wide variety of rocks older than the sheet itself. Some of these blocks are recognized through lithology alone; others are fossiliferous. Many blocks were derived from Pennsylvanian and Permian formations, especially from the Concha Limestone and quartzite of the Scherrer Formation. Mesozoic blocks are also common, and include arkosic sandstone of the Bisbee, its Glance Conglomerate Member, and some rhyolitic to andesitic volcanic rocks. A few blocks of Pinal Schist were also found. Many blocks are so small that the available lithologic criteria leave considerable uncertainty. Bedding is normally preserved in the blocks, there being only a little evidence of alteration or recrystallization. The tabular shape of the blocks is apparently controlled by bedding.

Because only a small area underlain by the Silver Bell Formation has been mapped for this study, only a few hints are obtained on the orientation and distribution of the blocks. Along the outcrop band west of the crest of the range, the blocks seem to be clustered low in the formation and to decrease in abundance southward. East of the crest of the range, the largest blocks are clustered in and near section 34, midway between Amole Peak and Sahuaro School. A clustering of rhyolite blocks occurs west of the school, and another, of andesite, occurs north of the school. Elongate blocks are mainly alined westnorthwest in the area of plate 9.

The Silver Bell Formation has not been dated directly in the Tucson Mountains or elsewhere, and correlative rocks are dated only indirectly by geologic means. Locally the formation postdates the Bisbee Formation and the rocks that may be Fort Crittenden Formation, as well as the time of deformation of these rocks, and it predates the intrusion of latite porphyry bodies that are associated with the Amole stock. Brown (1939) showed the stock itself intruding the "Cretaceous volcanic rocks," as he called them. Since the Fort Crittenden Formation is of late Late Cretaceous age, and the stock is 71-75 m.y. old by direct dating (possibly Maestrichtian), the Silver Bell is of much the same age.

A rhyolitic welded tuff, known as the Cat Mountain Rhyolite (Brown, 1939), overlies the Silver Bell Formation, probably disconformably. The rock is a massive, brownish-gray unit as much as $200 \mathrm{~m}$ thick that caps the rugged crest of the range and many of the rocky knobs east of the crest. To the south it seems to comprise four cooling units separated from each other by zones of weakly indurated tuff. It has a pronounced platy parting that is developed by alined crystals, porous lentils, and flattened pumiceous inclusions. This parting lies subparallel to the basal contact of the formation, but it typically dips slightly more steeply than that contact. If the orientation of the features that produced this parting are considered to be beddingrelated and perhaps enhanced by subsequent minor flowage, then the slight but persistent angular discordance suggests that the bedding resembles foreset beds of a massive ash-flow apron that was deposited subaerially in a delta-like form.

The Cat Mountain Rhyolite is an altered crystallithic tuff in which quartz, feldspar, and chloritized biotite make up a total of 10-20 percent of the rocks. An olive or greenish-gray hue is imparted by the alteration, which appears to have been a deuteric feature rather than thermal metamorphic. A few small blocks of limestone and of volcanic material unlike the Cat Mountain itself are found in places. Very little is known of the petrography or chemistry of the rock, but from the abundance of biotite, I suspect that the rock is a rhyodacite. Nevertheless, the term "rhyolite" is retained for its name until more complete studies are made.

The Cat Mountain Rhyolite has been dated as 70-73 m.y. old by P. E. Damon, and it is correlative with volcanic rocks in many other ranges (pl. 1). But by this correlation I do not mean that the welded tuff sheets were one continuous formation; rather they probably were deposited penecontemporaneously from separate volcanic centers under similar magmatic and tectonic conditions, and thus local stratigraphic names are appropriate.

A swarm of rhyolite porphyry or quartz latite porphyry dikes, known as the Silver Lily dikes, cuts rocks as young as the Cat Mountain Rhyolite and trends west-northwest across the area of plate 9. Individual dikes are commonly 1-2 km long and 5-15 $m$ wide, and they dip steeply or are vertical. In places they form en echelon patterns or branch, apparently following a system of tension fracture in the host rocks. The dike rocks contain a few phenocrysts of altered feldspar and biotite, and even fewer of quartz. 
In only one place, about $1.5 \mathrm{~km}$ east-northeast of the Arizona Sonora Desert Museum, was the biotite unchloritized and thus datable at 70 m.y. (P. E. Damon, written commun., 1977).

The origin of the igneous rocks of the Tucson Mountains has attracted much attention, largely because of the proximity of the area to a substantial community of geologists, and because of the occurrence of a remarkably extensive and coarse exotic-block breccia. The exotic-block breccia sheet was thought to be of purely tectonic origin by Brown (1939), but that interpretation was laid to rest by Kinnison (1959). Mayo (1971) favored a volcanotectonic origin, reviewed an abundant literature of similar features, and identified a source vent on the mountains southeast of Gates Pass (Mayo, 1976).

The evidence obtained from my study of part of the Tucson Mountains also favors a volcanotectonic origin and suggests a genetic pattern that could explain the associations of exotic-breccia volcanics of the Silver Bell, Salero-like welded tuff, and 70- to 75-m.y.-old stocks. In essence, a single major magmatic event probably led to the emplacement of the sequence of Silver Bell Formation, Amole stock, Cat Mountain Rhyolite, and Silver Lily dikes. The similarity of composition, age, and distribution support this inference. The entire event could have run its course over a few million years or even a substantially briefer time span. Probably the Silver Bell of the Tucson Mountains was extruded from several vents, of which the site near Gates Pass is one. Another vent is suspected near Amole Peak and perhaps another lies concealed beneath the Cat Mountain Rhyolite southwest of the largest exotic blocks. The Amole stock was then emplaced, perhaps at the site of the major volcanic vent. Shortly thereafter explosive volcanism spread the ashflow(?) deposit of Cat Mountain Rhyolite, perhaps again from a center near the Amole stock and from subsidiary centers along a line trending southeast from the stock. The dike swarm represents emplacement of the last magma of this igneous event; the next igneous event followed about $13 \mathrm{~m}$.y. later with andesite that is not present in the area of plate 9.

In summary, then, the Tucson Mountains are interpreted to have many geologic features and events in common with other ranges of southeastern Arizona, although the record is more fragmentary. Precambrian crystalline rocks of the basement are overlain by a standard Paleozoic sequence that is broken by bedding-plane and perhaps thrust faults wherever it is exposed. These formations are covered by Mesozoic rocks that also show evidence of decoupling from underlying rocks, probably on bedding-plane faults. An extensive upper plate was disharmonically folded and was transported northeastward, probably during Late Cretaceous time. Gravity sliding off a dome of Jurassic age is untenable. Most likely the bedding-plane thrust faults and folds were formed in response to a more widespread compressive stress, after which the small horst was formed. Lastly, the extensive volcanic episode of latest Cretaceous age occurred.

\section{CENTRAL CHIRICAHUA MOUNTAINS}

Deformed rocks of Paleozoic and Mesozoic age underlie the central part of the Chiricahua Mountains near Portal, Ariz., where they have been mapped by Raydon (1952) and Sabins (1957a) and compiled by Cooper (1959). During preparation of a regional structure section (Drewes, 1980, section $\left.D-D^{\prime}\right)$, anomalies were encountered near Round Valley using this early work, for a plate of Precambrian rocks was shown to rest upon younger rocks, and another plate of Mississippian to Permian rocks was also shown to overlie younger rocks. These relations suggest either overthrusting of a major plate, for which there was no other nearby support, or gravity gliding from a raised block, which seemed awkward because the only available source was raised at too recent a time, and itself contains rocks of Paleozoic age that are broken by bedding-plane faults. Consequently, an area of $35 \mathrm{~km}^{2}$ was remapped, and new observations led to the conclusions that (1) the thrust faults dip to the southwest rather than to the northeast, (2) the thrust plates are of the younger-over-older type and are not overthrusts, (3) the Precambrian crystalline rocks northeast of Round Valley may also be allochthonous and lie above a concealed thrust fault, and (4) the volcanic rocks west of Round Valley are not folded and consist of two sequences, the older of which may be associated with a vent.

The area of plate 10 is underlain by a wide assortment of formations typical of the whole region. Most of the formations are adequately described by Sabins (1957a and 1957b), and so their brief descriptions in the regional stratigraphic summary and on plate 1 suffice for this report. The rocks include Precambrian schist and granodiorite, a Paleozoic sequence from the Cambrian Coronado Sandstone to the Permian Concha Limestone, the Lower Cretaceous Bisbee Formation, and Tertiary dikes. A few observations are offered, however, on two formations mainly of volcanic rocks that are of mid-Tertiary age.

The Bisbee Formation is unconformably overlain by a unit here referred to as the dacite of Davis 
Mountain, which comprises flow breccia, tuff breccia, some tuffaceous sandstone, and genetically related intrusive dacite. The extrusive and epiclastic rocks consistently dip moderately to the southwest. The intrusive rock is in part also a breccia but elsewhere is more massive and has flow structures of varied and even steep attitudes. It consists of one main intrusive mass to the southwest and of several irregular sills, pods, and dikes, a few of which also cut the underlying Glance Conglomerate Member of the Bisbee Formation. The dacite contains phenocrysts mainly of plagioclase and amphibole, and is strongly propylitized. In addition, the main intrusive mass is pyritized, the pyrite mostly being oxidized and the rocks colored yellowish- to reddish-brown rather than the more typical greenish-gray. Intrusive dacite of Davis Mountain is dated at $28.6 \pm 1.2$ m.y. (zircon; fission-track method; C. W. Naeser, written commun., 1977). The abundance of flow breccia, intrusive breccia sheets, and mineralized plugs suggests that these rocks were formed as part of, or near, a volcanic vent.

Southwest of Round Valley the dacitic rocks are unconformably(?) overlain by a less altered formation, referred to as the andesite of Round Valley. A thin sheet of sandstone and conglomerate rich in clasts derived from the underlying dacite lies at the base of the andesite formation. Most of the formation consists of three massive lava flows of andesite, the lower two separated by a thin tuff unit that appears to lap across the edge of the lower flow and merge with the basal clastic sheet. A rhyolitic welded tuff(?) may be intercalated low in the formation at the south edge of the area of plate 10 . The andesite contains phenocrysts of clinopyroxene, hornblende, and plagioclase. While also propylitized, they are less altered than the dacitic rocks and are unmineralized. The andesite of Round Valley remains undated, having insufficient zircon for fission track counting. It presumably is younger than $28.6 \mathrm{~m} . y$. and older than $25.7 \mathrm{~m} . \mathrm{y}$., the age of some of the rhyolite tuff overlying dacitic rocks near Portal, a few kilometers south of the area of plate 10 .

At least two ages of deformation are recorded in the rocks of the area of plate 10 . Bedding-plane faulting of the Lower Cretaceous and older rocks was common, and the faults dip $40^{\circ}-80^{\circ}$ southwest, subparallel to the adjacent beds. The lowest of these faults generally separates the Upper Cambrian Coronado Sandstone from the Precambrian crystalline basement rocks, but east of Harris Mountain, limestone and dolomite containing conodonts of very Late Devonian age (John Repetski, written commun., 1978) occur in an infaulted part of the footwall. Because the fault between this limestone and dolomite and the adjacent granodiorite abuts the overlying thrust fault and does not merge gradually with it, the fault appears to be either a disharmonic, penecontemporaneous feature or an older feature. If it proves to be a penecontemporaneous structure, like other locally crosscutting faults in the abundantly thrust-faulted terranes, then the limestone and dolomite and the granodiorite must also be underlain by a thrust fault that remains concealed beneath the gravel deposits of San Simon Valley.

Northeast-trending faults also cut the thrustfaulted rocks. These are steeply dipping or vertical structures, and some of them abut the bedding-plane faults, such as the previously mentioned fault east of Harris Mountain. Probably the two sets are related, and possibly the northeast-trending faults have a large component of strike-slip movement. The largest of these faults, one of them south of Harris Mountain and the other south of Round Valley, also offset the volcanic formations and may have had a polyphase movement history.

A strong north-trending fault and some branch faults of this structure are known from adjacent areas to the south to have been active in middle or late Tertiary time. Very likely some movement, such as normal faulting, occurred along this system during the time of Basin and Range block movement. Evidence for major block faulting immediately east of the area of plate 10 was discussed in the section of this report on north-trending Basin and Range block faults.

In summary, this part of the Chiricahua Mountains has evidently undergone Late Cretaceous thrust faulting, followed by dacitic volcanism and mineralization perhaps of Oligocene age, followed by rhyolitic volcanism, and then block faulting. This sequence of events is compatible with that of most of southeastern Arizona. Thrust faults typically dip southwest and separate younger overlying rocks from older underlying rocks. If the Precambrian crystalline rocks are allochthonous, they were made so by the action of a thrust fault that is now concealed. The volcanic rocks of Round Valley are radiometrically dated as Oligocene, and likely mark the proximity of a volcanic vent.

\section{REGIONAL IMPLICATIONS OF THE TECTONIC SYNTHESIS}

Through this synthesis, southeastern Arizona may be viewed as a tectonic reference area in which the structural effects of three major tectonic regimes 
are emphasized. The structures formed during these deformational regimes are (1) northwest-trending complex faults, which moved many times; (2) thrust faults of Late Cretaceous age; and (3) block faults of middle and late Tertiary age.

A tectonic reference area is envisioned to provide a guide for the rapid application of selected geologic knowledge to a large surrounding terrane, much as a stratigraphic reference area or section is used. $\mathbf{A}$ tectonic reference area may be useful in that, through its use, it can mitigate the need to develop a comprehensive model of the structural development of each newly studied local area in which the record is very fragmentary and the topical objectives nontectonic. In addition, this synthesis may be useful in comparative studies with other regions containing major tectonic features that may project across southeastern Arizona.

The concept of a tectonic reference area must be applied with care, however, as is also the case with stratigraphic reference sections. In each instance, judgments are made about which features are important and which are less so; the unimportant feature of the reference area may be more important elsewhere. Of course, the greater the distance that data are projected from any reference area, the greater the likelihood that the data must be modified or blended with data from another area. Thus, while the structures produced during the three tectonic regimes are likely to be essential features of the development of much of the surrounding terrane, they may vary in detail. At much greater distances, of course, they must either die out or be replaced with a record of a markedly different sequence of events. On the other hand, some of the tectonic features thought to be of relatively local significance in southeastern Arizona may be distal records of important features or events elsewhere.

In applying the tectonic reference area concept to southeastern Arizona, caution is in order, because this application is only an initial effort at synthesizing the development of a region in which many questions remain unresolved and some interpretations are controversial. Granted that any synthesis retains a degree of subjectivity, the concept does offer the advantage of being based mainly on one set of observations and one style of interpretation applied regionally, rather than on a variety of styles of interpretation applied to locality after locality. Under this circumstance, it is likely that the tectonic synthesis here offered will be refined, modified, or eventually even replaced as new data become available and other syntheses are attempted. This study, then, represents a beginning rather than an end of our comprehension of a geologically complex region.

The notion of a tectonic reference area and the tectonic-geologic map compiled for this synthesis (Drewes, 1980) provide both scientific and economic utility, and they indicate where some interpretations may be tested. For example, for scientific purposes, the interpretations of large amounts of tectonic transport along certain faults should be tested. In southeastern Arizona, with a fairly detailed map showing the several kinds of major faults, and with a record of their probable history of movement, appropriately located and properly spaced stratigraphic sections may be sought to attempt such a test. The synthesis also makes clear the care needed to check for inconspicuous bedding-plane faults, if thickness parameters are used in such a test. The widespread occurrence of alteration or metamorphism causes other problems related to the obliteration of the initial character of rocks. And finally, testing the possible telescoping of facies through tectonic transport requires control of the initial rates of change of the facies parameters under consideration. The tectonic synthesis suggests that such stratigraphic testing will require extensive planning and meticulous execution, for few major tectonic blocks contain many complete sections.

The notion of a tectonic reference area and associated map also has practical merit in the pursuit of potential economic objectives. That the emplacement of mineral matter is related to certain tectonic events, and that tectonic features commonly guided the movement of mineralizing fluids, has long been accepted. Many local studies suggest that the widespread base-metal and noble-metal mineralization of the region was controlled by northeasttrending faults, and some studies point to northwesttrending faults; this synthesis indicates the likely role played by each of these fault sets. All of the largeand medium-sized mining districts of the region lie about 1-5 km from one of the exposed or projected segments of the northwest-trending complex faults. The local ore controls commonly have been secondorder faults that trend northeasterly and may abut the master faults. This generalized distribution of mineral concentrations probably reflects an optimum position in a physical-chemical system that grades away from a source of the mineralizing fluids. It may also reflect the attraction of mineral deposition in local areas to tensionally disrupted rocks adjacent to a generally tight strike-slip fault zone up which the fluids moved. In other words, the strike-slip faults at depth were likely ducts for fluids, which migrated upward and outward into second- 
and third-order faults and certain rock types in which lower pressure conditions alternated with higher pressure conditions. The projection and verification of master faults and second-order faults would be useful steps in the search for potentially mineralized ground, especially where the cover is not prohibitively thick, and such sites may be inferred from the regional map (Drewes, 1980). But other relations between rocks and mineralization are also implied by the synthesis.

Some segments of the master faults seem to be more favored as sites of mineralization than others. The synthesis shows that many intrusive bodies and some kinds of volcanic rocks were emplaced along or near the master (complex) faults. Their abundance and kind vary, and rocks of a late Cordilleran age, particularly quartz latite porphyry, are especially favorable. Apparently segments of master faults with too few igneous rocks and also those with too many igneous intrusions (which obliterate the fault system and form a "fault scar") are less favorable than are those with an intermediate number of stocks. The central part of the Santa Rita Mountains exemplifies the situation of too many magma masses emplaced along a northwest-trending fault, and the Canelo Hills and the northern end of the Huachuca Mountains are examples of areas with too few.

The tectonic synthesis of southeastern Arizona provides an anchor point for tectonic studies of continental scale, and it is found to be compatible with the currently favored concepts of global plate tectonics. Through geologic time the southeastern Arizona region has been pictured by various investigators to have lain in or along (1) the Texas lineament, (2) a miogeosyncline flanking the craton, (3) the Cordilleran orogenic belt, and (4) the Basin and Range physiographic province. The results of this synthesis support or clarify some of these broadly regional projections.

1. In the section of this paper, "Northwest-trending system of complex faults," the question of the Texas lineament in southeastern Arizona was reviewed. If the conclusions from Arizona are applicable to the lineament, then the feature is a long-lived zone of multiphased history exposed along a linear belt, but it is not necessarily itself linear like the San Andreas fault zone. Some of these faults were active during Precambrian time, and segments of other faults were reactivated as late as late Tertiary time. Perhaps the single most important conclusion to be drawn from these faults is that almost since the start of recorded geologic time the rocks were structurally anisotropic, and the response to many of the subsequent stresses applied to the region was influenced by the ancient flaws.

2. Through most of Paleozoic time the region lay in the stable miogeosyncline on the southwestern flank of the North American craton. This assignment is based largely on stratigraphy, and it remains unchanged as a result of this tectonic study. However, detailed studies of Paleozoic sections must reckon with bedding-plane faults in many localities and at various horizons. Their detection may require detailed mapping of rocks as much as a few kilometers from a given stratigraphic section. Furthermore, paleogeographic reconstructions may have to recognize that the original distribution of lithologic or biostratigraphic features were substantially modified through subsequent tectonic events.

3. Southeastern Arizona is considered to lie in the Cordilleran orogenic belt of North America, which extends from Alaska to Guatemala. Along its trace the belt forms lobate segments, and in the southwestern United States the belt is seen to separate into a northeastern sub-belt (Colorado Plateau and Rocky Mountains), in which vertical tectonics are dominant, and a southwestern sub-belt (fold and thrust zone) in which horizontal tectonics are more common. The border between these subbelts is clearly demarked southward to southern Nevada, but its connection, if any, with the belt of compressively deformed rocks extending from west Texas southward through Mexico has been unclear. As a result of the present tectonic synthesis, the border is suggested to extend through Arizona and western New Mexico, perhaps in two major lobes, thereby giving the orogenic belt a degree of continuity similar to that found along other major orogenic belts of the world.

Across the Cordilleran orogenic belt, the style of deformation in southeastern Arizona shows many similarities to that in Canada, northern Utah, southern Nevada, and northern Mexico, and also some variations (Drewes, 1978). The similarities, of course, favor a genetic unity of the entire orogenic belt. The differences that do occur between features herein interpreted for southeastern Arizona and those of the other parts of the belt are not greater than those found among the other areas themselves. And these differences may be rationally explained as reflecting variations from place to place of the depth or lateral position of the well-studied tectonic profiles, of preorogenic structural anisotropy of the rocks, or of postorogenic tectonic development. In essence, the Cordilleran orogenic belt is seen to be a continuous zone primarily of compressive 
deformation. To the southwest it is older, more abundantly invaded by magmas, and more altered thermally, and to the northeast it is younger and less affected by magmas. In places, some gravityimpelled plates may also have moved off regionally thickened and thrust-faulted terrane, toward the foreland terrane of the thrust belt, as exemplified by areas in northern Montana.

The Cordilleran orogenic belt, thus unified, is compatible with the plate tectonic model currently favored for the North American plate and the several plates of the eastern Pacific Ocean. These plates converged from spreading centers in the midAtlantic and the mid-Pacific beginning in Triassic or Jurassic time. Plate collision took place along the western continental margin, and large parts of the oceanic plates were subducted beneath the continental plate. Convergence continued over a substantial span of geologic time, at least $120 \mathrm{~m}$.y., with convergence rates in the order of $5-10 \mathrm{~cm}$ per year over at least the Late Cretaceous part of that span. A relatively thin upper part of the continental plate was compressed, perhaps thickened, and gradually thrust northeastward. Simultaneously, a thicker mass of subducted plate, and perhaps the margin of the underridden plate, were heated, remobilized into magma, and in part transferred upward to penetrate the crumpled and thrust-faulted skin of surface rocks. Apparently, then, the tectonics of southeastern Arizona are but local reflections of larger crustal movements.

4. Finally, southeastern Arizona is also part of the Basin and Range province, an extensive terrane of linear ranges and valleys with a Tertiary history of block faulting. This Tertiary history is the best known chapter in the development of southeastern Arizona, although many details on the relations of this faulting, magma movement, and local gravity movements off raised areas remain to be clarified. While the wide extent of this block faulting inferred on the regional tectonic-geologic map (Drewes, 1980) may be considered too bold by some, I feel that this projection makes a more coherent and informative tectonic picture. Most faults of the region trend north, reflecting the orientation of a regional tensional stress. Clusters of northwest-trending Basin and Range faults are believed to be responses to the older crustal anisotropy of the rocks under the younger tensional stress. Clearly, reactivation of faults and structural inhomogeneities are at the heart of the geologic complications of southeastern Arizona. The conditions set up in simple fashion for laboratory purposes cannot be applied with impunity to many field situations; our basic data must still be obtained mainly from field relations.

\section{REFERENCES CITED}

Aguilera, J. G. [translated by A. C. Lawson], 1920, The Sonora earthquake of 1887: Seismol. Soc. America Bull., v. 10, no. 1, p. $31-44$.

Albritton, C. C., Jr., and Smith, J. F., Jr., 1957, The Texas lineament, in Relaciones entre la tectónica y la sedimentación: Internat. Geol. Cong., 20th Mexico, D. F., 1956 [Trabajos], v. 2, no. 5, p. 501-518.

Anderson, C. A., 1951, Older Precambrian structures in Arizona: Geol. Soc. America Bull., v. 62, no. 11, p. 1331-1346.

Armstrong, A. K., 1962, Stratigraphy and paleontology of the Mississippian system in southwestern New Mexico and adjacent southeastern Arizona: New Mexico Bur. Mines and Mineral Resources Mem. 8, 99 p.

Armstrong, A. K., and Silberman, M. L.; 1974, Geologic map of the central Peloncillo Mountains, Hidalgo County, New Mexico: U. S. Geol. Survey Open-File Rept. 74-11.

Arnold, L. C., 1971, Structural geology along the southern margin of the Tucson Basin, Tucson, Ariz., Arizona Univ. Ph.D. dissert., 99 p.

Baker, C. L., 1935, Major structural features in trans-Pecos Texas, in Sellards, E. H., and others, The geology of Texas, v. 2, Structural and economic geology: Texas Univ. Bull., no. 3401, p. 137-214.

Bally, A. W., Gordy, P. L., and Stewart, G. A., 1966, Structure, seismic data and orogenic evolution of southern Canadian Rocky Mountains: Bull. Canadian Petroleum Geology, v. 14, no. 3, p. 337-381.

Bikerman, Michael, and Damon, P. E., 1966, K-Ar chronology of the Tucson Mountains, Pima County, Arizona: Geol. Soc. America Bull., v. 77, no. 11, p. 1225-1234.

Brown, W. H., 1939, Tucson Mountains, an Arizona Basin Range type: Geol. Soc. America Bull., v. 50, no. 5, p. 697-760.

Burchfiel, B. C., Fleck, R., Secor, D. T., Vincelette, R. R., and Davis, G. A., 1974, Geology of the Spring Mountains, Nevada: Geol. Soc. America Bull., v. 85, no. 7, p. 1013-1022.

Butler, B. S., Wilson, E. D., and Rasor, C. A., 1938, Geology and ore deposits of the Tombstone District, Arizona: Univ. Arizona Bull., v. 9, no. 1, 114 p.

Cooper, J. R., 1959, Reconnaissance geologic map of southeastern Cochise County, Arizona: U.S. Geol. Survey Mineral Inv. Field Studies Map MF-213.

1960a, Reconnaissance geologic map of Willcox, Fisher Hills, Cochise, and Dos Cabezas quadrangles, Cochise and Graham Counties, Arizona: U.S. Geol. Survey Mineral Inv. Field Studies Map MF-231.

$1960 \mathrm{~b}$, Some geologic features of the Pima Mining District, Pima County, Arizona: U.S. Geol. Survey Bull. 1112-C, p. 63-103.

1961, Turkey-track porphyry-A possible guide for correlation of Miocene rocks in southeastern Arizona: Arizona Geol. Soc. Digest, v. 4, p. 17-33.

1971, Mesozoic stratigraphy of the Sierrita Mountains, Pima County, Arizona: U.S. Geol. Survey Prof. Paper 658-D, $42 \mathrm{p}$.

1973, Geologic map of the Twin Buttes quadrangle, southwest of Tucson, Pima County, Arizona: U.S. Geol. Survey Misc. Geol. Inv. Map I-745.

Cooper, J. C., and Silver, L. T., 1964, Geology and ore deposits of the Dragoon quadrangle, Cochise County, Arizona: U.S. Geol. Survey Prof. Paper 416, 196 p.

Corbitt, L. L., and Woodward, L. A., 1970, Thrust faults in the Florida Mountains, New Mexico, and their regional tectonic significance, in New Mexico Geol. Soc. Guidebook, 21st Field Conf., Tyrone-Big Hatchet Mountains-Florida 
Mountains region: Socorro, N. M., New Mexico Bur. Mines and Mineral Resources, p. 69-75.

Creasey, S. C., 1967, Geologic map of the Benson quadrangle, Cochise and Pima Counties, Arizona: U.S. Geol. Survey Misc. Geol. Inv. Map I-470.

Creasey, S. C., and Quick, G. L., 1955, Copper deposits of part of the Helvetia mining district, Pima County, Arizona: U. S. Geol. Survey Bull. 1027-F, p. 301-323.

Creasey, S. C., Jackson, E. D., and Gulbrandsen, R. A., 1961 Reconnaissance geologic map of parts of the San Pedro and Aravaipa Valleys, south-central Arizona: U.S. Geol. Survey Mineral Inv. Field Studies Map MF-238.

Crittenden, M. D., Jr., 1961, Magnitude of thrust faulting in northern Utah, in Geological Survey - Research 1961: U.S. Geol. Survey Prof. Paper 424-D, p. D128-D131.

Cunningham, J. E., 1964, Geology of the north Tumacacori foothills, Santa Cruz County, Arizona: Tucson, Ariz., Arizona Univ. Ph. D. dissert, 197 p.

Damon, P. E., and Bikerman, Michael, 1964, K-Ar dating of volcanic and orogenic events in the Tucson Mountains, Arizona: Geol. Soc. America Spec. Paper 76, p. 269-270.

Damon, P. E., Erickson, R. C., and Livingston, D. E., 1963, $\mathrm{K}$-Ar dating of Basin and Range uplift, Catalina Mountains: Natl. Acad. Sci.-Natl. Research Council Pub. 1075, Nuclear Sci. Ser. Rept. 38, p. 113-121.

Damon, P. E., and others, 1965, Correlation and chronology of ore deposits and volcanic rocks: Arizona Univ. Geochronology Lab., Geochem. Sec., Ann. Prog. Rept. no. COO-689-50, Contract AT (11-1)-689 to U.S. Atomic Energy Commission Research Div., 140 p.

Davidson, E. S., 1973, Geohydrology and water resources of the Tucson Basin, Arizona: U.S. Geol. Survey Water Supply Paper 1939-E, 81 p. [1974].

Davis, G. H., 1975, Gravity-induced folding of a gneiss dome complex, Rincon Mountains, Arizona: Geol. Soc. America Bull., v. 86, no. 7, p. 979-990.

Drewes, Harald, 1971a, Geologic map of the Sahuarita quadrangle, southeast of Tucson, Pima County, Arizona: U.S. Geol. Survey Misc. Geol. Inv. Map I-613.

$1971 \mathrm{~b}$, Geologic map of the Mount Wrightson quadrangle, southeast of Tucson, Santa Cruz and Pima Counties, Arizona: U.S. Geol. Survey Misc. Geol. Inv. Map I-614. 1971c, Mesozoic stratigraphy of the Santa Rita Mountains, southeast of Tucson, Arizona: U.S. Geol. Survey Prof. Paper 658-C, $81 \mathrm{p}$. 1971d, Roadlog for Rincon Mountains 2-day field trip: U.S. Geol. Survey open-file rept., 9 p. 1972a, Structural geology of the Santa Rita Mountains, southwest of Tucson, Arizona: U.S. Geol. Survey Prof. Paper 748, $35 \mathrm{p}$.

1972b, Cenozoic rocks of the Santa Rita Mountains, southeast of Tucson, Arizona: U.S. Geol. Survey Prof. Paper 746, 66 p.

1973, Large-8cale thrust faulting in southeastern Arizona: Geol. Soc. America Abs. with Programs, v. 5, no. 1, p. 35

1974, Geologic map and sections of the Happy Valley quadrangle, Cochise County, Arizona: U.S. Geol. Survey Misc. Geol. Inv. Map I-832.

1976a, Laramide tectonics from Paradise to Hells Gate, south eastern Arizona: Arizona Geol. Soc. Digest, v. 10, p. 151-167.

1976b, Plutonic rocks of the Santa Rita Mountains, southeast of Tucson, Arizona: U.S. Geol. Survey Prof. Paper 915, 75 p.

1976c, The Cordilleran thrust belt (Laramide orogeny) between Nevada and Chihuahua: Internat. Geol. Cong., 25th, Sydney, Australia, Abs., v. 1, p. 118-119.
1977, Geologic map of the Rincon Valley quadrangle, Pima and Cochise Counties, Arizona: U.S. Geol. Survey Misc. Geol. Inv. Map I-997.

1978, The Cordilleran orogenic belt between Nevada and Chihuahua: Geol. Soc. America Bull., v. 89, no. 5, p. 641-657. 1980, Tectonic map of southeastern Arizona: U.S. Geol. Survey Misc. Geol. Inv. Map I-1109.

Drewes, Harald; and Cooper, J. R., 1973, Reconnaissance geologic map of the west side of the Sierrita Mountains, Palo Alto Ranch quadrangle, Pima County, Arizona: U.S. Geol. Survey Misc. Field Studies Map MF-538.

Drewes, Harald, and Thorman, C. H., 1978, New evidence for multiphase development of the Rincon metamorphic core complex, east of Tucson, Arizona: Geol. Soc. America Abs. with Programs, v. 10, no. 3, p. 103.

Drewes, Harald, and Williams, F. E., 1973, Mineral resources of the Chiricahua Wilderness area, Cochise County, Arizona: U.S. Geol. Survey Bull. 1385-A, 53 p.

Enlows, H. E., 1955, Welded tuffs of the Chiracahua National Monument, Arizona: Geol. Soc. America Bull., v. 66, no. 10, p. 1215-1246.

Epis, R. C., 1956, Geology of the Pedregosa Mountains, Cochise County, Arizona: Berkeley, Calif., Univ. California, Ph.D. dissert., 263 p.

1958, Addendum to Early Paleozoic strata in southeastern Arizona, by R. C. Epis and C. M. Gilbert, 1957 [cited below]: Am. Assoc. Petroleum Geologists Bull., v. 42, no. 11, p. 2750-2756.

Epis, R. C., and Gilbert, C. M., 1957, Early Paleozoic strata in southeastern Arizona: Am. Assoc. Petroleum Geologists Bull., v. 41, no. 10, p. 2223-2242.

Epis, R. C., Gilbert, C. M., and Langenheim, R. L., Jr., 1957, Upper Devonian Swisshelm Formation of southeastern Arizona: Am. Assoc. Petroleum Geologists Bull., v. 41, no. 10, p. 2243-2256.

Erickson, R. C., 1968, Geology and geochronology of the Dos Cabezas Mountains, Cochise County, Arizona, in Southern Arizona Guidebook 3: Tucson, Ariz., Arizona Geol. Soc., p. 192-198.

Finnell, T. L., 1970, Formations of the Bisbee Group, Empire Mountains quadrangle, Pima County, Arizona, in G. V. Cohee, R. G. Bates, and W. B. Wright [compilers], Changes in stratigraphic nomenclature by the U.S. Geological Survey, 1968: U.S. Geological Survey Bull. 1294-A, p. A28-A45. 1971, Preliminary geologic map of the Empire Mountains, Arizona: U.S. Geol. Survey open-file map.

Fleck, R. J., 1970, Tectonic style, magnitude, and age of deformation in the Sevier orogenic belt in southern Nevada and eastern California: Geol. Soc. America Bull., v. 81, no. 6 , p. $1705-1720$.

Fowler, G. M., 1938, Montana Mine, Ruby: Univ. Arizona Bur. Mines Bull. 145, Geol. ser. 12, p. 119-124.

Fries, Carl, Jr., 1962, Reseña de la geologia del Estado de Sonora, con enfasis en el Paleozoico: Asoc. Mexicana Geólogos Petroleros Bol., v. 14, no. 11-12, p. 257-273.

Gillerman, Elliot, 1958, Geology of the central Peloncillo Mountains, Hidalgo County, New Mexico, and Cochise County, Arizona: New Mexico Bur. Mines and Mineral Resources Bull. 57, 152 p.

Gilluly, James, 1956, General geology of central Cochise County, Arizona, with sections on Age and correlation by A. R. Palmer, J. S. Williams, and J. B. Reeside, Jr.: U.S. Geol. Survey Prof. Paper 281, 169 p.

Gilluly, James, Cooper, J. R., and Williams, J. S., 1954, Late Paleozoic stratigraphy of central Cochise County, Arizona: U.S. Geol. Survey Prof. Paper 266, 49 p. 
Guilbert, J. M., and Sumner, J. S., 1968, Distribution of porphyry copper deposits in the light of recent tectonic advances, in Southern Arizona Guidebook 3: Tucson, Ariz., Arizona Geol. Soc., p. 97-112.

Hayes, P. T., 1970a, Mesozoic stratigraphy of the Mule and Huachuca Mountains, Arizona: U.S. Geol. Survey Prof. Paper 658-A, 28 p.

1970b, Cretaceous Paleogeography of southeastern Arizona and adjacent areas: U.S. Geol. Survey Prof. Paper 658-B, 42 p. 1972, Stratigraphic nomenclature of Cambrian and Lower Ordovician rocks of easternmost southern Arizona and adjacent westernmost New Mexico: U.S. Geol. Survey Bull. 1372-B, 19 p.

Hayes, P. T., and Cone, G. C., 1975, Cambrian and Ordovician rocks of southern Arizona and New Mexico and westernmost Texas: U.S. Geol. Survey Prof. Paper 873, 98 p.

Hayes, P. T., and Drewes, Harald, 1968, Mesozoic sedimentary and volcanic rocks of southeastern Arizona, in Southern Arizona Guidebook 3: Tucson, Ariz., Arizona Geol. Soc., p. $49-58$.

Hayes, P. T., and Landis, E. R., 1964, Geologic map of the southern part of the Mule Mountains, Cochise County, Arizona: U.S. Geol. Survey Misc. Geol. Inv. Map I-418.

1965, Paleozoic stratigraphy of the southern part of the Mule Mountains, Arizona: U.S. Geol. Survey Bull.1201F, $43 \mathrm{p}$.

Hayes, P. T., and Raup, R. B., 1968, Geologic map of the Huachuca and Mustang Mountains, southeastern Arizona: U.S. Geol. Survey Misc. Geol. Inv. Map I-509.

Hayes, P. T., Simons, F. S., and Raup, R. B., 1965, Lower Mesozoic extrusive rocks in southeastern Arizona-The Canelo Hills Volcanics: U.S. Geol. Survey Bull. 1194-M, 9 p.

Hedge, C. E., 1960, Sodium-potassium ratios in muscovites as a geothermometer: Tucson, Ariz., Arizona Univ. M.S. thesis, $29 \mathrm{p}$.

Hill, R. T., 1902, The geographic and geologic features, and their relation to the mineral products of Mexico: Am. Inst. Mining Engineers Trans., v. 32, p. 163-178.

Kelly, V. C., 1955, Regional tectonics of the Colorado Plateau and their relationship to the origin and distribution of uranium: New Mexico Univ. Pubs. Geology, no. 5, 120 p.

Keith, S. B., and Barrett, L. F., 1976, Tectonics of the central Dragoon Mountains: A new look: Arizona Geol. Soc. Digest, v. 10 , p. $169-204$.

Kinnison, J. E., 1958, Geology and ore deposits of the southern section of the Amole mining district, Tucson Mountains, Pima County, Arizona: Tucson, Ariz., Arizona Univ. M.S. thesis, $123 \mathrm{p}$.

1959, Chaotic breccias in the Tucson Mountains, Arizona, in Arizona Geol. Soc. Guidebook 2, Apr. 1959: Arizona Geol. Soc. Digest, 2d Ann., p. 49-57.

Knight, L. H., Jr., 1970, Structure and mineralization of the Oro Blanco mining district, Santa Cruz County, Arizona: Tucson, Ariz., Arizona Univ. Ph.D. dissert., 251 p.

Kottlowski, F. E., 1960, Summary of Pennsylvanian sections in southwestern New Mexico and southeastern Arizona: New Mexico Bur. Mines and Mineral Resources Bull. 66, $187 \mathrm{p}$.

Lacy, W. C., 1959, Structure and ore deposits of the East. Sierrita area, in Arizona Geol. Soc., Guidebook 2, April, 1959: Arizona Geol. Soc. Digest, 2d Ann., p. 184-192.

Layton, D. W., 1957, Stratigraphy and structure of the southwestern foothills of the Rincon Mountains, Pima County, Arizona: Tucson, Ariz., Arizona Univ. M.S. thesis, $87 \mathrm{p}$.
Lucarelli, Ludano, 1967, Mapa Geologico de la parte septentrional del estado de Sonora: Exploración de Yacimientos de minerales metalicos con la colaboración de las Naciones Unidas: Mexico, D. F., Consejo de Recursos Naturales No Renovables, 23 maps.

Lynch, D. J., 1976, Basalt eruptions in the Bernardino volcanic field of southeastern Arizona: Geol. Soc. America Abs. with Programs, v. 8, no. 5, p. 604-605.

McRae, O. M., 1966, General geology and some structural features of the Courtland-Gleeson area, Cochise County, Arizona: Soc. Mining Engineers Trans., v. 235, no. 2, p. 133-138.

Marjaniemi, D. K., 1968, Tertiary volcanism in the northern Chiricahua Mountains, Cochise County, Arizona, in Southern Arizona Guidebook 3: Tucson, Ariz., Arizona Geol. Soc., p. 209-214. 1969, Geologic history of an ash-flow sequence and its source area in the Basin and Range province of southeastern Arizona: Tucson, Ariz., Arizona Univ. Ph. D. dissert, 176 p.

Marvin, R. F., Stern, T. W., Creasey, S. C., and Mehnert, H. H., 1973, Radiometric ages of igneous rocks from Pima, Santa Cruz, and Cochise Counties, Arizona: U.S. Geol. Survey Bull. 1379, 27 p.

Mayo, E. B., 1958, Lineament tectonics of some ore districts in the southwest: Mining Eng., v. 10, p. 1169-1175.

1968, A history of geologic investigations in the Tucson Mountains, Pima County, Arizona, in Southern Arizona Guidebook 3: Tucson, Ariz., Arizona Geol. Soc., p. 155-170. 1971, Defense of "Volcanic orogeny": Arizona Geol. Soc. Digest, v. 9, p. 39-60.

1976, Intrusive fragmental rocks directly or indirectly of igneous origin: Arizona Geol. Soc. Digest, v. 10, p. 347-430.

Mayo, E. B., and Davis, G. H., 1976, Origin of the Red Hills-Piedmontite Hills uplift: Arizona Geol. Soc. Digest, v. 10 , p. 103-132.

Moody, J. D., and Hill, M. J., 1955, Wrench-fault tectonics: Geol. Soc. America Bull., v. 67, no. 9, p. 1207-1246.

Mudge, M. R., 1972, Structural geology of the Sun River Canyon and adjacent areas, northwestern Montana: U.S. Geol. Survey Prof. Paper 663-B, 52 p.

Neuerburg, G. J., and Granger, H. C., 1960, A geochemical test of diabase as an ore source for the uranium deposits of the Dripping Spring district, Arizona: Neues Jahrb. Mineralogie Abh., v. 24 (Festband Ramdohr), p. 759-797.

Pashley, E. F., 1966, Structure and stratigraphy of the central, northern, and eastern parts of the Tucson Basin, Pima County, Arizona: Tucson, Ariz., Arizona Univ., Ph. D. dissert., 273 p.

Percious, J. K., 1969, Geochemical investigation of the Del Bac Hills, Pima County, Arizona, Tucson, Ariz., Arizona Univ. M.S. thesis, 29 p.

Price, R. A., and Mountjoy, E. W., 1970, Geologic structures of the Canadian Rocky Mountains between Bow and Athabasca Rivers-A progress report: Geol. Soc. Canada Spec. Paper 6, p. 7-25.

Ransome, F. L., 1904, Geology and ore deposits of the Bisbee quadrangle, Arizona: U.S. Geol. Survey Prof. Paper 21, 167 p. 1915, The Tertiary orogeny of the North American Cordillera and its problems, in W. N. Rice and others, Problems of American geology: New Haven, p. 287-376.

Raydon, G. T., 1952, Geology of the northeastern Chiricahua Mountains, Arizona: Berkeley, Calif., California Univ. M.A. thesis, $138 \mathrm{p}$.

Richard, Kenyon, and Courtright, J. H., 1966, Structure and mineralization at Silver Bell, Arizona, in Geology of the 
porphyry copper deposits, southwestern North America: Tucson, Ariz., Univ. of Arizona Press, p. 157-163.

Roberts, R. J., Hotz, P. E., Gilluly, James, and Ferguson, H. G., 1958, Paleozoic rocks of north-central Nevada: Am. Assoc. Petroleum Geologists Bull., v. 42, p. 2813-2857.

Rubey, W. W., and Hubbert, M. K., 1959, Role of fluid pressure in mechanics of overthrust faulting. II. Overthrust belt in geosynclinal area of western Wyoming in light of fluidpressure hypothesis: Geol. Soc. America Bull., v. 70, no. 2, p. $167-206$.

Sabins, F. F., Jr., 1957a, Geology of the Cochise Head and western part of the Vanar quadrangles, Arizona: Geol. Soc. America Bull., v. 68, no. 10, p. 1315-1342.

$1957 \mathrm{~b}$, Stratigraphic relations in the Chiricahua and Dos Cabezas Mountains, Arizona: Am. Assoc. Petroleum Geologists Bull., v. 41, no. 3, p. 446-510.

Schmitt, H. A., 1966, The porphyry copper deposits in their regional setting, in Geology of the porphyry copper deposits, southwestern North America: Tucson, Ariz., Univ. of Arizona Press, p. 17-33.

Shride, A. F., 1967, Younger Precambrian geology in southern Arizona: U.S. Geol. Survey Prof. Paper 566, 89 p.

Simons, F. S., 1972, Mesozoic stratigraphy of the Patagonia Mountains and adjoining areas, Santa Cruz County, Arizona: U.S. Geol. Survey Prof. Paper 658-E, 23 p.

1974, Geologic map and sections of the Nogales and Lochiel quadrangles, Santa Cruz County, Arizona: U.S. Geol. Survey Misc. Geol. Inv. Map I-762.

Simons, F. S., Raup. R. B., Hayes, P. T., and Drewes, Harald, 1966, Exotic blocks and coarse breccias in Mesozoic volcanic rocks of southeastern Arizona, in Geological Survey research 1966: U.S. Geol. Survey Prof. Paper 550-D, p. D12-D22.

Spangler, D. P., 1969, A geophysical study of the hydrogeology of the Walnut Gulch Experimental Watershed, Tombstone, Arizona: Tucson, Ariz., Arizona Univ. Ph. D. dissert., 103 p.

Stewart, J. H., and Poole, F. G., 1974, Lower Paleozoic and uppermost Precambrian miogeosyncline, Great Basin, western United States, in W. R. Dickenson, ed., Tectonics and sedimentation, a symposium: Soc. Econ. Paleontologists and Mineralogists Spec. Pub. 22, p. 28-57.

Stoyanow, A. A., 1936, Correlation of Arizona Paleozoic formations: Geol. Soc. America Bull., v. 47, no. 4, p. 459-540.

Swan, N. M., 1975, The Texas lineament-Tectonic expression of a Precambrian orogeny: Geol. Soc. America Abs. with Programs, v. 7, no. 7, p. 1288-1289.

Taliaferro, N. L., 1933, An occurrence of Upper Cretaceous sediments in northern Sonora, Mexico: Jour. Geology, v. 41 , no. 1 , p. $12-37$

Thorman, C. H., Drewes, Harald, and Lane, M. E., 1978 Mineral resources of the Rincon Mountains Wilderness study area, Pima County, Arizona-Chap. A, Geological and geochemical investigations: U.S. Geol. Survey Open-File Rept. 78-596, 102 p.

Trischka, Carl, 1938, Some Arizona ore deposits; Pt. 2, Mining districts, Bisbee district: Arizona Bur. Mines Bull. 145, Geol. ser. 12 (Arizona Univ. Bull., v. 9, no. 4), p. 32-41.

Turner, F. J., and Weiss, L. E., 1963, Structural analysis of metamorphic tectonics: New York, McGraw-Hill, 545 p.

West, R. E., and Sumner, J. S., 1973, Bouguer gravity anomaly map of Arizona: Tucson, Ariz., Univ. Arizona, Dept. of Geosciences.

Wilson, E. D., 1939, Pre-Cambrian Mazatzal Revolution in central Arizona: Geol. Soc. America Bull., v. 50, p. 1113-1164.

Wilson, E. D., Moore, R. T., and Cooper, J. R., 1969, Geologic map of Arizona: Arizona Bur. Mines and U.S. Geol. Survey.

Wood, P. A., 1959, Tertiary deposits in southern Arizona, in Arizona Geol. Soc. Guidebook 2, Apr. 1959: Arizona Geol. Soc. Digest, 2d Ann., p. 58-59.

Zeller, R. A., Jr., 1970, Geology of the Little Hatchet Mountains, Hidalgo and Grant Counties, New Mexico: New Mexico Bur. Mines and Mineral Resources Bull. 96, 23 p.

Zeller, R. A., Jr., and Alper, A. M., 1965, Geology of the Walnut Wells quadrangle, Hidalgo County, New Mexico: New Mexico Bur. Mines and Mineral Resources Bull. 84, 105 p. 


$$
\checkmark
$$




\section{INDEX}

[Italic page numbers indicate major references]

Abrigo Fault ............................................ $\begin{array}{r}\text { Page } \\ 79\end{array}$ Abrigo Formation 21, 27, 40, 47, 48, 49, 59, 61, 62, 83 Abrigo-Gold Hill fault zone

79 Abrigo Limestone See Abrigo Formation.

Adobe Canyon, folds ............................................... 32

Alaskite ……………………………………...39, 50

Alberta, Canada, thrust belts ….......................... 22, 35

Albite ……................................................. 34, 49, 5

Allanito...

Alluvium .......

Amado stock

Amado stock

See also Bis

Amoch also Bisbee Formati

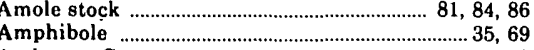

Anderson Canyon

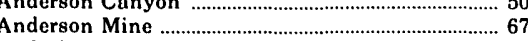

Andesite...

Angelica Arkose

Apache Canyon Formation …………………………. 84

Apache Group ……............................................. 26, 40

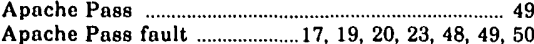
Apache Pass fault ...................17, 19, 20, 23, 48, 49, 50

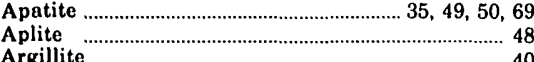

Arkose

Atascosa Mountains …………………........ 20, 26, 72,76

B

Babocomari fault $18,19,20,68,69$ Babocomari River ........................................68, 69

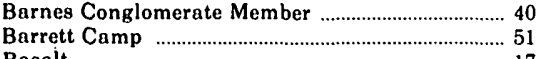

Basin and Range faults ................10,16, 20, 35, 87, 90 Basin and Range province …….................. 72, 89, 90 Bathtub Formation ............................................... 43, 66

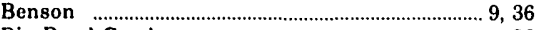
Big Bend Creek ……………………………………... 26 Biotite …………………………..... 35, 49, 50, 51, 68, 79 Bisbee Formation … 15, 21, 29, 42, 43, 46, 47, 50, 51, Bisbee Group ……...... 20, 25, 32, 43, 64, 69, 76, 79, 84 Bisbee West fault ................................................. 79 Black Prince Limestone ……………............................ 41 Bolsa Quartzite .. 29, 40, 48, 49, 57, 61, 62, 64, 78, 82 Bowie Mountains ………........................... 39, 47, 50

Brown Mountain 49
$.1 . . .83$

C

Cabullona area, Sonora ……………………………... 7 (1) ........................................... 78 California lineament

Cananea .........

Canelo Hills ……………..........................1 18, 38, 42, 89 Canelo Hills Volcanics …............................. 42, 68, 83, 84 Castle Dome ……………………………………… 54, 66 Cat Mountain .............................................. 19, 21, 85 Cat Mountain Rhyolite ………………….... 28, 85, 86 Central Chiricahua Mountains ………………........ 86 Central Dragoon Mountains ................................57, 62 Chaetetes milliporaceous ......................................... 49 Charleston-Tombstone area
Chihuahua .................................................................................. 22,23
Chiricahua Mountains ......... 6, 11, 19, 24, 39, 40, 44 $55,66,74$
.........6, 6, $11,19,24,39,40,44$

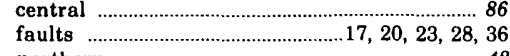

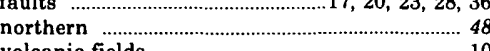
volcanic fields ............................................... 10 Chiricahua National Monument ……………...... 19, 20

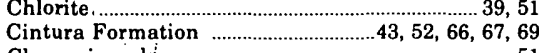

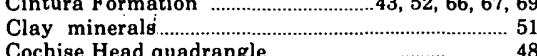

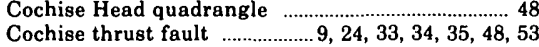
Cochise thrust fault $\ldots \ldots \ldots \ldots \ldots \ldots . .9,24,33,34,35,48,53$
Cochise thrust plate $\ldots \ldots \ldots \ldots \ldots \ldots \ldots . . .24,25,29,33,41,47$ Colina Limestone …………........................... 41, 48, 71 College Peaks

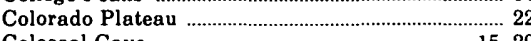

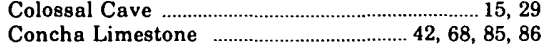
Concha Limestone …............................. 42, 68, 85, 86 Continental ......................................................... 16 Copper Belle Monzonite Porphyry ………………....34

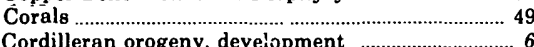
Cordilleran orogeny, development ……………1....... 6 Cordilleran thrust belt ……...................................... 35

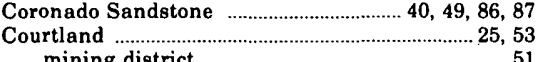

mining district ...............

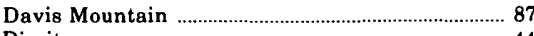

Diorite ……………………………………….... 44

Dividend fault $\ldots . . . \ldots \ldots \ldots \ldots \ldots \ldots \ldots \ldots \ldots \ldots \ldots \ldots \ldots \ldots \ldots . .18,20,21,79$
Dolomite

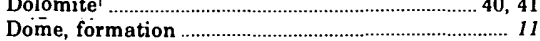

Dos Cabezas ……………………………………........... 17, 24

Dos Cabezas Mountains .........................17, 21, 23, 39, 40 Dos Cabezas Mountains ...................................... 7, 74 Douglas ............... 16, 18, 24, 28, 32, 43, 45, 57,83
57,62 57,62
46 northern southern $\ldots . .46$ Dragoon thrust fault .......................... Dripping Spring Formation ...................................... 40 Dynamics, fault …………………………………….... 19 E

Earp Formation $41,48,71$ Earthquak

El Paso Dolomite ………………………………..... 40, 49

Emigrant Canyon fault ………………...........19, 19, 20,50 Empire Mountains …................................... 38, 75, 84 Epitaph Dolomite ……....................41, 46, 47, 48, 52 Escabrosa Limestone ............ 21, 41, 47, 48, 49, 50, 52,
$54,61,83$

Esperanza Mine $54,61,83$
$\ldots \ldots \ldots . . .29$

\section{F}

Feldspar:

Ferosa Canyon .............................................66, 66 Fort Bowie thrust fault. See Hidalgo thrust fault. Fort Critteneden Formation ............ 35, 43, 53, 65, 67, Fourr Canyon plate $\quad 68,69,74,75,78,80,85$

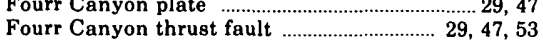
G

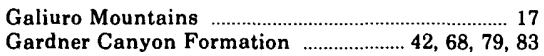

Gates Pass

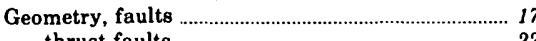
lance Conglomerate Member …........... 43, 47, 49, 52 $66,68,69,71,76,84,85$ Glance Creek …….................................................. 76 Glance Member. See Glance Conglomerate Member. Glance Mine ……….................................................. 78

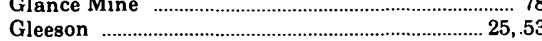
Gleeson Quartz Monzonite …………………………..... 9, 25 Gleeson Quartz Monzonite …………………........ 9, Gleeson stock

Gold Hill

$(-. .9,35,39,43,66$ Granodiorite …......................11, 35, 39, 44, 50, 51, 6 Grapevine Canyon

Greaterville

Green Valley

Gringo Gulch Volcanics

Grosvenor Hills, volcanic field..................................34

Grosvenor Hills Volcanics $\ldots$

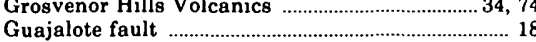

Gulf of California, alluvial deposits ......................... 32

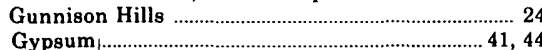

H

Hachita Formation ……............................................. 41

Hamburg fault …………………………………..... 32

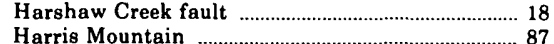

Harris Ranch Monzonite ………………………...... 34

Happy Valley …….................................... 26, 29, 39

Happy Valley quadrangle, mapping …………….... 46

Hells Gate ................................................................. 31

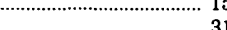

Helvetia

Hidalgo thrust fault ............................................... 19

Hidalgo thrust plate

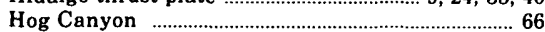

Hog Canyon

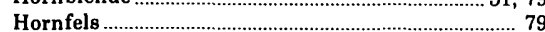

Hornfels
Horquilla Limestone

Horquilla Limestone $\quad$........... 15, 21, 24, 27, 41, 47, 48,

Huachuca Mountains $\quad 50,52,54,62,7,72,76,83$

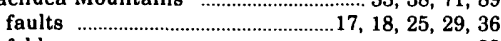
folds

northern

volcanic rocks

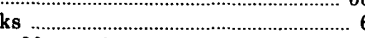

Huachuca Quartz Monzonite …………………….... 32

Huachuca stock
Humble No. 1 State well …………………………………......... 27

J, K, L

Jasper

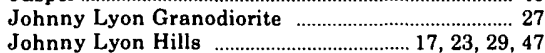

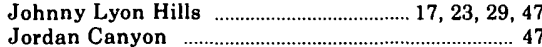

Jordan Canyon

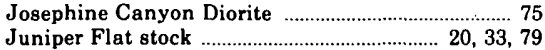

Keating Formation

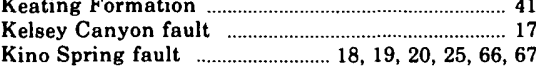

Lamprophyre ...

Leslie Canyon …………………………………...... 54

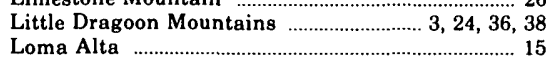




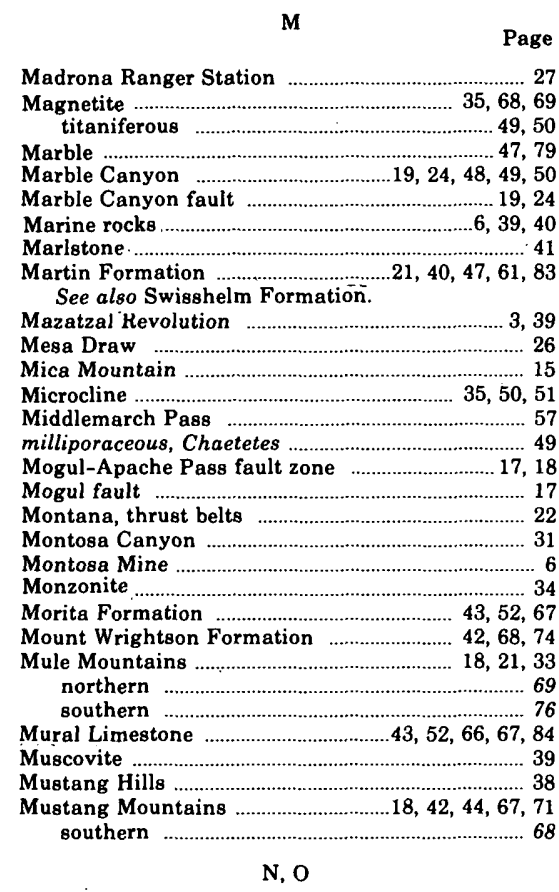

Nevada, Cordilleran thrust belt thrusting .........

Nevada lineament

Nogales

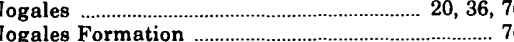

North American crato

Northern Chiricahua Mountains

Northern Dragoon Mountains

Northern Huachuca Mountain

Northern Mule Mountains

Northern Tumacori Mountains

Northern Whetstone Mountains

Old Tucson

Oligoclase

Olivine.

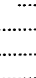

Ox Frame Volcanica

$48,50,51,79$

\section{$P, \mathbf{Q}$}

Pajarito Mountains Pantano Formation

Paramore Crater

Paradise Formation ............................................ 41

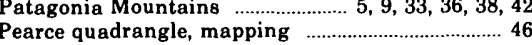

Pedregosa Mountains ………..............18, 26, 36, 55, 66

Pedregosa Mountains
Peloncillo Mountains .........................................10, 18, 17, 36, 41

Peloncillo Mountains ……………………………...... 40

Perilla Mountains ............................................................. 64

Phyllite ……………........................................... 39, 47, 48

Picacho de la Calera. See Twin Peaks.

Piedmontite Hills. See Brown Mountain.

Pinal Schist ..... 3, 15, 26, 39, 45, 47, 48, 50, 57, 82, 85 Pioneer Formation ……………............................. 28

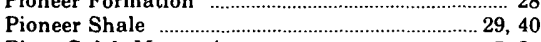
Piper Gulch Monzonite …………………………....5, 34 Pistol Hill …………………………………………...... 28

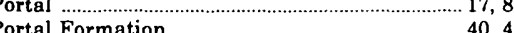

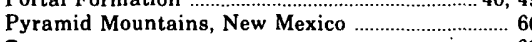

Pyroxene .
Page

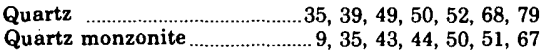
Quartz monzonite stocks, Roncom Mountains ..... 11 R

Rainvalley Formation ….... 42

Recreation Red Beda

42,83

Red Mountain ...............................................17, 48 Redbird Hill Rhyodacite

Rhyodaci

...68, 74

Rincon Mountains $\quad$................................ 9, 11, 23, 25, 33, 39 gneissic dome

Rincon Valley

Rincon Valley Granodiorite-1........................... 27

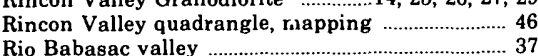
Rio Babasac valley

Rio de los Alisos valley

Rio Magdalena

Robert Mountains

Rodolfo Formation ...

Roskruge Mou

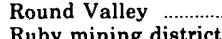

Ruby mining district

Ruby Star Granodiorite ………………………………….... 28

Ruby Star stock $\mathbf{S}$

Sacramento Hill stock

(1)

Sacramento porphyry stock

Saguaro National Monument ....

Salero fault zon

Salero Formation

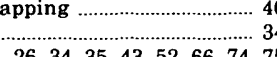
. San Cayetano Mountains ……..................16, 10,36, 37, 44 Sangamon Interglaciation Sanidine

San Juan Basin

San Pedro River

San Pedro thrust fault

San Pedro thrust plate

San Pedro Valley

$16,23,24,25,31,36$ San Rafael Valley ………………………………….....26, 26, 36 San Simon-San Bernardino Valley ... 36,37 San Simon Valley ..................... 16, 17, 24, 36, 37, 8 ? Santa Catalina complex fault …….................... 25, 27 Santa Catalina Group Santa Catalina Mountains …………….............11, 23, 46 Santa Cruz River …….....................................37, 76 Santa Cruz thrust fault ........................26, 27 Santa Cruz thrust plate ………................... 26, 27, 33

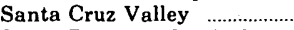
Santa Rita complex fault ……………………........18, 20 Santa Rita-Harshaw Creek fault .................. 18 Santa Rita Mountains ........... 9, 10, 16, 20, 33, 38, 39 ,

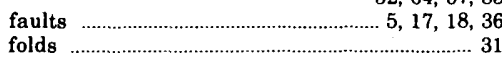

thrust fault

San Xavier glide plate

15,18

San Xavier glide plate ................................................ 37

Sawmill Canyon complex fault ......................... 6, Sawmill Canyon fault 20 e.............17, 18, 19, 20, 26 .

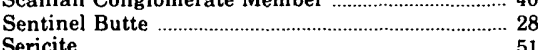

Shellenberger Canyon Formation

Sherrer Formation ……............................42, 69, 83, 85

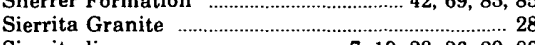

Sierrita line ………………..... 7, 19, 23, 26, 29, 80

ierrita Mountains $38,75,80$
Sierrita Mountains-Continued

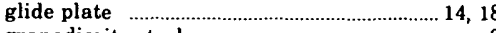

granodiorite stocks

tear fault

thrust fault

volcanic rocks

Silver Bell Formation Silver Bell Mountains …………………......... 18, 19, 2

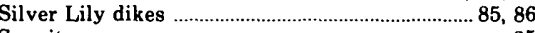

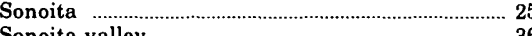
Sonoita valley .......... Sonora .......................................................... 6, 1

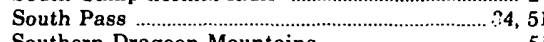
Southern Dragoon Mountains …………………..... 51

Southern Mustang Mountains 68

Sphene

Squaw Gulch

Squaw Gulch Granite ................................................

Steele Hill

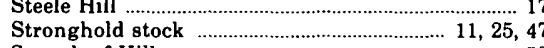

Sugarloaf Hill ...................................................... 53

Sugarloaf Quartz Latite ……..........................52,66

Sulphur Springs Valley …................17, 24, 36, 44, 50

Superior ……......................................................... 23

Sus picnic area
Swisshelm Formation

Swisshelm Formation ............................... 40, 54

southern

66,71

T

Tactite Tanque Verde Mountains ..................................

Tascuela Red Beds ......

Temporal Formation ………………………………... 43, 66

Texas Canyon stock ................................................. 24, 25

Texas lineament …....................................... 16, 20, 89

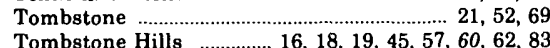

Tombstone Hills _............ 16, 18, 19, 45, 57, 60, 62, 83

Tumacacori Mountains ……............................... 10, 33, 79

Tungsten King normal fault

Turkey Creek

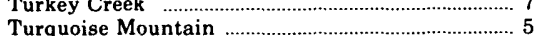

Turney Ranch Formation …………………………1. 8 84

Tucson Mountains …….........6, $9,18,23,43,44,52,80$

Twin Buttes ……………………………………….... 2?

$\mathrm{U}, \mathrm{V}, \mathrm{w}, \mathrm{z}$

Uncle Sam Porphyry ………………………………….... 52

ah, thrust belt ………………………………………... 35

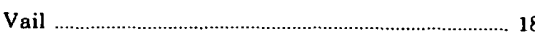

Wakefield Camp

$\ldots .32$
27,42

.

Walnut Gap Volcanics. See Walnut Gap Formation.

Whetstone Mountains ..................18, 26, 28, 36, 38, 64

northern …………………………………………..... 62

Wickenburg

Wildcat Wel

Willcox

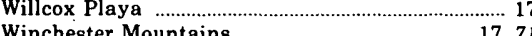

Wood Mountain

Wod Mountain ......... fault

Wrong Mountain Quartz Monzonite ……………….... 45

Wyoming, thrust belts ……………............. 22

Zircon

$35,49,50,69$ 